\title{
The Outsider: Elizabeth P. MacCallum, the Canadian Department of External Affairs, and the Palestine Mandate to 1947
}

by

\author{
Richard Newport
}

A thesis submitted to the Faculty of Graduate and

Postdoctoral Affairs in partial fulfillment of the requirements for the degree of

Doctor of Philosophy

in History

Carleton University

Ottawa, Canada

(C) 2014

Richard Newport 


\section{Abstract}

Elizabeth Pauline MacCallum was Canada's leading expert on the Middle East in the first part of the twentieth century. From 1925 to 1935, as a research analyst and author for the Foreign Policy Association (FPA), she gained international recognition for her scholarship on the problems and challenges confronting the Middle East and the British Mandate in Palestine, the central ground of dispute between the Arab and Jewish peoples. MacCallum joined Canada's Department of External Affairs (DEA) in 1942, not as a regional specialist, but as a wartime clerk. Where there had been previously no clear official thinking regarding the Middle East, MacCallum, using a combination of expertise and persistence, slowly gained recognition among her peers for her understanding of the region.

The purpose of this thesis is to examine MacCallum's ideas about the Middle East by investigating the foundation, development, and substance of her ideas about the region. The thesis also identifies the role that she played in the Department of External Affairs and interrogates the manner in which she applied her ideas as a member of the DEA. In particular, this study assesses her part in the making of Canada's first policy towards the Middle East, which came together in 1947.

In assessing MacCallum's ideas and her role as a member of the Department of External Affairs during the period 1942-1947, the thesis contends that she can best be understood as an outsider — a specialist in a department of generalists, a woman in a department of men, and an Arabist in a department dominated by Eurocentric and balance of power thinking. The thesis explores her efforts to put into practice her ideas as a basis 
for Canada's approach to the Arab-Zionist dispute. The thesis further demonstrates that MacCallum made clear the dangers that the problem of Palestine posed to international peace and security, and the likely split that it would cause among the Great Powers over the territory's fate. She opposed the division of Palestine between its Arab and Jewish peoples in 1947 and predicted the Middle Eastern war soon to come. 


\section{Table of Contents}

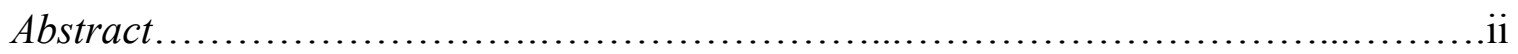

Introduction ....................................................................

Chapter 1 An All-Embracing Imperialism, 1925-41.................................27

A Balanced Skepticism....................................................27

MacCallum and the Imperialists.......................................... 31

The Great War and Great Power Maneuverings................................. 38

MacCallum and Wartime Agreements.....................................49

Mandates, Protectorates, and Alliance Treaties................................57

Tolstoy’s Farm, Back to New York and Home Again..........................68

Conclusion.......................................................... 75

Chapter 2 An Insider's (and a Male's) Department of External Affairs, 1942-43.........78

Entering External Affairs............................................. 78

A Political Department, A Narrow Department................................85

Gravitating Around Men................................................93

MacCallum's Entry into External.....................................99 
Conclusion.

Chapter 3 A Voice Beginning to be Heard, 1944-45 .108

Britain's Early Palestine Policies and MacCallum's Reactions.................110

The Arab Rebellion, Peel, and Woodhead

The MacDonald White Paper of 1939 139

Emergent Canadian Government Thinking on Palestine.

Conclusion

Chapter 4 San Francisco: MacCallum and Canada at the Margins, 1945.

The Making of a Delegation.

MacCallum, Trusteeship, and Palestine

"There is Really Nothing to be Discussed There".

Anglo-American Differences, and Canada in the Middle

The Working Paper on Trusteeship.

Trusteeship Confirmed, Palestine Unresolved. .230

Conclusion .235 
Chapter 5 Palestine and MacCallum's Warnings, 1945-46.

Transformations

Canada's Growing Unease and MacCallum's Concerns.

MacCallum, External Affairs, and the Anglo-American Dispute. .258

The Anglo-American Report and MacCallum's Responses.

Conclusion

Chapter 6 Pearson's Triumph, MacCallum's Tragedy: Palestine 1947

Moving Palestine to New York. 305

An UNSCOP in View.

An UNSCOP Investigation and MacCallum’s Misgivings. ... .325

"Cutting the Palestinian Knot".

The Ad Hoc Committee and a MacCallum Opportunity.

The Ascendance of Pearson, and MacCallum's Continued Opposition.

Conclusion .371

Conclusion .374

Bibliography .385 


\section{Introduction}

Elizabeth Pauline MacCallum was Canada's leading expert on the Near and Middle East in the first part of the twentieth century. ${ }^{1}$ From 1925 to 1935 , as a research analyst and author for the Foreign Policy Association (FPA), she gained international recognition for her scholarship on the problems and challenges confronting the Middle East, and Palestine in particular. MacCallum joined Canada's Department of External Affairs (DEA) in 1942, not as a regional specialist, but as a wartime clerk. Where there had been previously no clear official thinking regarding the Middle East, MacCallum, using a combination of expertise and persistence, slowly gained recognition among her peers for her understanding of the region. In 1947, MacCallum became a foreign service officer and was chosen as Canada's technical adviser during the United Nations' special debate on Palestine, the central ground of dispute between Arabs and Jews.

The purpose of this thesis is to examine MacCallum's ideas about the Middle East by investigating the foundation, development, and substance of her ideas about the Middle East during the period 1925 to 1935 . The thesis also investigates the role that she played in the Department of External Affairs and interrogates the manner in which she applied her ideas as a member of the DEA. In particular, this study assesses her part in Canada's first policy towards the Middle East, which came together in 1947.

\footnotetext{
1 Royal Institute of International Affairs (RIIA), The Middle East: A Political and Economic Survey (London and New York: RIIA, 1951), p. 1. "The 'Middle East' is a political rather than a geographic term and came into general use as a consequence of the establishment of the British Middle East Command. . . .The strict geographic rule was formally to distinguish between the Near East, comprising Greece, Bulgaria, Turkey, the Levant [Lebanon and Syria] and Egypt, and the Middle East, Arabia, Mesopotamia, Persia, and Afghanistan." During the Second World War, the term Near East was replaced by the term Middle East as a consequence of the establishment of the British Middle East Command and corresponding civilian organizations. For the sake of clarity, the term Middle East will be used throughout to designate both the Near and Middle East.
} 
The thesis begins with an examination of the articles and books on the Middle East that MacCallum wrote prior to joining the DEA. It was through her numerous writings for the New York-based Foreign Policy Association (FPA), a non-profit organization dedicated to inspiring the American public to learn more about the world, that MacCallum expressed her concerns about the disastrous effects that European imperialism had had on the Middle East during the interwar period. She was convinced that the policies of Britain and France ignored Arab rights of self-determination and reinforced anti-Western sentiment throughout the Middle East. She was particularly critical of Great Britain's stance regarding Palestine, which she believed had impeded the natural development of the Arab community and reinforced a long-term animosity between the Arab and Jewish communities. This animosity, believed MacCallum, led the two peoples to adopt more and more violent means to achieve their ends. She was equally critical of the League of Nations' Mandate System, ${ }^{2}$ which she believed had legitimated Europe's seizure of Arab lands and endorsed Great Power abuses. MacCallum concluded that the League's unwillingness to defend or protect Arab rights had alienated the Arab World and made difficult their co-operation in the finding of peaceful solutions to the problems besetting the Middle East.

In assessing MacCallum's ideas and her role as a member of the Department of External Affairs during the period 1942-1947, the thesis contends that she can best be

\footnotetext{
${ }^{2}$ The League of Nations Mandate System gave legal status to certain territories transferred from the control of one country to another following the end of World War I. The Mandate System was established under Article 22 of the Covenant of the League of Nations, entered into on June 28, 1919. With the dissolution of the League of Nations after World War II, it was stipulated by the Great Powers at the Yalta Conference of 1945 that the remaining mandates should be placed under the Trusteeship of the United Nations, subject to future discussions and formal agreements.
} 
understood as an outsider - a specialist in a department of generalists, a woman in a department of men, and an Arabist in a department dominated by Eurocentric and balance of power thinking. ${ }^{3}$ By analysing MacCallum's viewpoint and her efforts to familiarize colleagues with and advise the department on the Palestine problem, it is demonstrated that MacCallum's ideas were consistent with her prewar outlook. The thesis investigates her efforts to put into practice her ideas as a basis for Canada's approach to the ArabZionist dispute. ${ }^{4}$ The thesis further demonstrates that MacCallum, by making clear the dangers that the dispute posed to international peace and security, and the split it caused among the Great Powers over Palestine's fate, succeeded in bringing to the DEA's attention the seriousness of the issue and of Canada's relations with the Middle East.

What the DEA did with MacCallum's briefings is also part of the analysis. The thesis will also examine how MacCallum's perceptions and analysis of the Arab-Zionist dispute helped the Canadian government construct its first policy towards the Middle East in 1947. Her ideas were thoroughly tested and challenged in that year when the United Nations, at the behest of the British government, took up the long-disputed matter

${ }^{3}$ Robert Kaplan, The Arabist: The Romance of an American Elite (New York: The Free Press, 1993), pp. 67. William A. Stoltzfus, Jr., a former U. S. diplomat in Damascus, said that in "the Middle Ages an Arabist was only a physician who had studied Arab medicine. . . In the nineteenth and twentieth centuries an Arabist was merely a student of Arabic, like a Hellenist or a Latinist." Today "Arabists are generally viewed as "men and women . . . who read and speak Arabic and who passed many years of their professional lives ... in the Arab World, whether as diplomats, military attachés, intelligence agents, or even scholar-adventurers."

${ }^{4}$ Esco Foundation, Palestine: A Study of Jewish, Arab, and British Policies, Vol. 1 (New Haven, Conn.: Yale University Press, 1947), pp. 2-4 Also see: Walter Laqueur, A History of Zionism: From the French Revolution to the Establishment of the State of Israel (New York: Schocken Books, 1972), p. 40. Zionism arose in late 19th century Europe in response to growing anti-Semitism. It sought the restoration of a Jewish homeland in Palestine. This movement came to be known as "Political Zionism." 
of the disposition of Palestine. The thesis assesses the part that MacCallum played during the General Assembly's extraordinary discussions, which pitted the Arab and Moslem Worlds against the Zionists and the Christian states of the West. The thesis reveals the profound differences within the DEA about Middle East that materialized during the United Nations deliberations. Elizabeth MacCallum combatted Lester B. Pearson, the under-secretary of state for external affairs and Canada's leading diplomat. It was a contest that matched MacCallum, the department's first area specialist, against Pearson's broader and pragmatic approach to conflict management and international relations. Pearson's view prevailed, and yet MacCallum's analyses were correct. Within 24 hours of the United Nations' decision to partition Palestine, the Middle East was plunged into a war that she thought inevitable. To this day, the Middle East has been a focal point for Arab and Moslem unrest, Great Power calculations and miscalculations, and a constant challenge for the United Nations.

From her beginnings, Elizabeth MacCallum was an outsider — a shadow and advantage that followed her throughout her life. The youngest of four children, she was born in Marash, Turkey, in 1895 to Frederick and Mima MacCallum, Canadian Presbyterian missionaries working in a largely Moslem country. ${ }^{5}$ Constance Padwick, one of Britain's first women missiologists in the twentieth century, observed that all of the MacCallum children grew up aware of the strong differences that separated them

\footnotetext{
${ }^{5}$ Stanley E. Kerr, The Lions of Marash: Personal Experiences with American Near East Relief, 1919-1922 (Albany, N. Y.: State University of New York, 1973), pp-ix-xx. Marash was the primary missionary center with a highly literate and progressive citizenry. "By the turn of the twentieth century, no less than a third of the city's thirty thousand Armenians had become adherents of the Protestant Evangelical Church or the Eastern — rite Catholic Church.”
} 
from the world outside their father's seminarian mission. ${ }^{6}$ One of the earliest lessons that the youngest MacCallum was to learn was the power of emerging nationalist and religious differences. ${ }^{7}$ Throughout her formative years in Marash, she witnessed the restiveness of nationalist movements that confronted the Ottoman Empire. She saw the Ottoman Turkish Muslims follow the Eastern Orthodox Christians' footsteps in challenging the Ottomans' decadent way of life. This coincided with the surging Turkish and Arab Moslem march towards independence. From Marash, MacCallum saw religious and nationalist intolerance and hatred erupt into violence. She progressively came to view the Arab and Moslem Worlds as lands dominated by difference and defined by conquest. These foundational experiences shaped MacCallum's international perspective and her sympathies for Arabs and Moslems who were outraged by Western intrusions into their lands.

MacCallum's experience apart was not limited to Turkey. In the summer of 1910, the MacCallum family returned to Canada, where she attended Kingston Collegiate Institute. While she excelled scholastically, winning the Sir Sanford Fleming scholarship in mathematics and the Watkins scholarship, she chafed at the lack of the intellectual freedom that she had known during her formative years in Marash. Home-schooled, she had benefitted from her parents' diverse approach to education, gleaning knowledge from both the Arab World and Western thought. In contrast, MacCallum's academic training in

${ }^{6}$ Constance E. Padwick, Call to Istanbul (London: Longmans, Green and Co., 1958), p. 3. A year after Elizabeth MacCallum was born, three seminarian missions were burnt down by Moslems, including the MacCallum's.

${ }^{7}$ Arnold J. Toynbee, "The Ottoman Empire in World History," Proceedings of the American Philosophical Society, Vol. 99, No. 3 (June, 1955), p. 124. 
Canada was dominated by secular and parochial perspectives. In Kingston, little was said of the Arab World or indeed of the world outside of Canada.

At Queen's University in Kingston, MacCallum again excelled academically, winning Gold Medals in English and History. She demonstrated a proficiency in political science, philosophy, and political economy. Under the direction of O. D. Skelton, the future under-secretary of state for external affairs, MacCallum was selected for a tutorial course in political theory and history. ${ }^{8}$ However, as teachers and evangelists, her parents faced continual economic hardship. They were unable to support their daughter's academic pursuits. Financial insecurity forced MacCallum on several occasions to set aside her studies to seek jobs that would enable her return to school.

After receiving her Master of Arts from Queen's University in 1919, MacCallum began post-graduate studies in political science and modern European history at Columbia University in 1921. An informal but crucial part of MacCallum's study at Columbia was provided by her residence at International House. It was there that she met graduate students from countries directly affected by issues of the day. Some of these students went on to become delegates and advisers at the United Nations and other international institutions. In 1922, plagued again by financial difficulties, MacCallum left Columbia and accepted a position in Toronto at the Social Service Council of Canada, where she worked as assistant editor of Social Welfare. In 1924, after saving enough

${ }^{8}$ Civil Service Commission of Canada, "Civil Service Application Form," July 10, 1942, Civil Service Commission Papers, Library and Archives Canada (LAC), RG 32, Vol. 451, File: Elizabeth Pauline MacCallum. See MacCallum's Curriculum Vitae (CV), p. 3. 
money and living very frugally for two years, she returned to New York to complete her doctoral degree.

In 1925, on the recommendation of her professors, MacCallum halted her doctoral studies and joined the Foreign Policy Association (FPA). The Association provided the economic security that she desperately desired. More importantly, it offered her the opportunity to become a specialist in Middle Eastern affairs. During the next ten years, she wrote three books and more than thirty articles on Syria, Iraq, Egypt, Palestine, Turkey, Albania, and the Balkans. The sense of separation that MacCallum often had experienced was now reinforced by an ear infection that rendered her virtually deaf. Her hearing impairment prevented her from fully interacting with her contemporaries, and in due course, forced her to resign in 1931 from the FPA and retire to a two-acre farm in southern Ontario, near the small township of Uxbridge. MacCallum sought quiet seclusion for "a period of combined writing and gardening." 9 During this hiatus, MacCallum produced numerous studies of the Middle East's interwar developments growing Arab nationalism, anti-imperialism, and the Arab resentment at the Mandate System, particularly the Palestine Mandate.

In 1942, MacCallum accepted an invitation to join the Department of External Affairs as a wartime clerk. The department was searching for individuals temporarily to shore up their ranks, since some of their members were on active service overseas. She was not hired as an expert or diplomat-in-training. Women were still prohibited from

\footnotetext{
9 Julia Ettinger, "Elizabeth MacCallum: A Graduate Profile," The Queen's Review (November, 1952), p. 215.
} 
entering the Canadian foreign service as professional diplomats. For MacCallum, an internationally recognized Middle East expert, this must have been disheartening. Her specialized skills were seen as of little value to the wartime needs of the department. Canada had no diplomatic representation in the Middle East. No Canadian diplomat spoke Arabic or had studied the history of the region. Nor had the government or the department expressed any interest in developing a policy towards the region that was different from Great Britain's — that being the main filter through which Canada then viewed international affairs. MacCallum was a temporary wartime employee, one of many. For a time, her gender, her credentials, and the department's priorities kept her on the periphery.

By war's end, however, MacCallum's specialized knowledge of the Middle East and international affairs was viewed with greater interest and respect by the department's senior officials. She had demonstrated her value by helping the government traverse the politically dangerous issue of Britain's 1939 Palestine policy, Canadians' response to it, and the growing Anglo-American tensions over Palestine. The department valued her appraisals of the mounting frictions and rivalries among the Great Powers over their competing economic and political interests in the Middle East. In her 1944 and 1945 memoranda, she drew attention to a Middle East that was a playground for the Great Powers and a danger to world peace. ${ }^{10}$ Palestine in particular could be the spark that ignited a Great Power conflict. The traditionally cautious Prime Minister Mackenzie

10 Elizabeth MacCallum, "Palestine: Postwar Policy and the 1939 White Paper," [n.d.], William Lyon Mackenzie King Papers (King Papers), LAC, MG 26, J4, Vol. 310, File: 3308; MacCallum, "The Crimea Conference," March 25, 1945, LAC, King Papers, MG 26, J4, Vol. 310. 
King, who was apprehensive about the Middle East and its connection to postwar international tensions, shared this concern.

Post-1945 rivalries, at the heart of MacCallum's concerns, had been presaged by wartime developments and suspicions. Germany's Stalingrad and North Africa campaigns, combined with covert Nazi subversion efforts in Syria, Egypt, Iraq, and Iran, and efforts to entice Turkey to join the Axis powers, had demonstrated Hitler's clear sense of the importance of the region. Middle East historian Rashid Khalidi concluded that, if the Nazis had been successful in their strategy, "Hitler would have controlled the southern Soviet Union, nearly the entire Mediterranean and Black Sea basins, and most of the Middle East." ${ }^{11}$ At the heart of the Nazi plans was stopping the flow of oil to the Allied armies. A victory at Stalingrad would have deprived the Russians access to the rich Baku oil fields in the Caucasus, and the North African campaign would have denied the British and Americans access to the Suez Canal and the oil fields and refineries of Iraq and Iran, upon which the Allied war effort depended. Breaking Turkey's neutrality, moreover, would have closed the Turkish Straits to the Allies, and given the Germans outright control of the Eastern Mediterranean. ${ }^{12}$ Thus the strategic importance of the Middle East, and its oil resources, was obvious to the Americans, British, and Soviets. As the historian of oil, David Yergin, pointed out:

The lessons of World War II, the growing economic significance of oil, and the magnitude of Middle East resources all served . . . to define the preservation of access to that oil as a prime element in American and

\footnotetext{
${ }^{11}$ Rashid Khalidi, Sowing Crisis: The Cold War and American Dominance in the Middle East (Boston: Beacon Press, 2009), p. 42.

${ }^{12}$ Ibid.
} 
British — and Western European - security. Oil provided the point at which foreign policy, international economic considerations, national security, and corporate interests would all converge. ${ }^{13}$

No sooner had the war ended than the Great Powers' wartime unity came flying apart over the Middle East. Capitalizing on Britain's declining political and economic power, the U. S. Truman administration initiated a foreign policy program that sought to guarantee the United States a leading place in Middle East affairs, and a tight grip on Persian Gulf oil. ${ }^{14}$ The British, on the other hand, were forced to take a more pragmatic approach to their imperial holdings in the Middle East. While the Middle East remained one of the most important strategic areas in the postwar world for the British, they recognized that they could no longer ensure the region's security by themselves. Without the support and goodwill of the Americans, Britain's influence as a regional power would decline. More importantly, the British recognized that the Russians would attempt to realize their historic ambition of controlling the Turkish Straits and attaining unfettered access to the Mediterranean. ${ }^{15}$ This was London's greatest fear. For more than three hundred years, Britain had worried that the Russians would seize the Middle East, the gateway to India. Thus, the British prime minister, Clement Attlee, had to play for time, maintain the status quo as best he could, and navigate a steady course of flexibility and firmness with the Americans. ${ }^{16}$

\footnotetext{
${ }^{13}$ David Yergin, The Prize: The Epic Quest for Oil, Money, and Power (New York: Simon \& Schuster, 1991), p. 410.

${ }^{14}$ Fred Lawson, "The Iranian Crisis of 1945-1946 and the Spiral Model of International Conflict," International Journal of Middle East Studies, Vol. 21, No. 3 (August, 1989), p. 308.

${ }^{15}$ Wm Roger Louis, The British Empire in the Middle East, 1945-1951 (Oxford: Clarendon Press, 1984), p. 4.

${ }^{16}$ Ibid, p. 73.
} 
By late 1945 British concerns had been justified. The Soviet Union, through direct and indirect stratagems, attempted to seize strategically important areas in Turkey and Iran. In a calculated move, in violation of the Yalta Conference agreements of earlier 1945, Vyacheslav Molotov, the Soviet foreign minister, sent a note to Selim Sarper, the Turkish ambassador to Moscow, informing him that Moscow had officially "renounced" the twenty-year old Soviet-Turkish Treaty of Friendship and Neutrality. ${ }^{17}$ Molotov declared that the Soviet Union's new found prestige and power demanded a bigger piece of the geo-strategic calculus. In return for an amended friendship agreement, Moscow demanded "bilateral" revision of the Montreux Convention of 1936, which had given Turkey control over the Bosporus Straits and the Dardanelles, and about which MacCallum had warned her colleagues in the DEA. ${ }^{18}$ Soviet demands were expanded, and it was apparent to American and British officials that the real aim of the Soviets was not the revision of the friendship and the straits agreements, but the domination of Turkey and unrestricted access to the Aegean and Eastern Mediterranean Seas. Dean Acheson, the U. S. under-secretary of state, fully understood the dangers of such concessions. "If the Soviet Union succeeds in its objective [of] obtaining control over Turkey it [would]

\footnotetext{
17 Averell Harriman, "Ambassador in Moscow to U. S. Secretary of State," March 21, 1945, Foreign Relations of the United States (FRUS), 1945, Vol. 8, Near East and Africa (Washington, D.C.: Government Printing Office, 1969), p. 1220. Also see: Vladislav Zubok and Constantine Pleshakov, Inside the Kremlin's Cold War: From Stalin to Khrushchev (Cambridge, MA: Harvard University Press, 1996), p. 91.

18 Elizabeth MacCallum, “The Middle East," [n.d., 1944?], MacCallum Papers, pp. 1-18. For more information on Soviet-Turkish postwar relations, see: J. R., "The Background of Russo-Turkish Relations," The World Today, Vol. 2, No. 2 (Feb., 1946), pp. 58-59; Harry Howard, "The Soviet Union and the Middle East," Annals of American Academy of Political and Social Sciences, Vol. 263, The Soviet Union Since World War Two (May, 1949), p. 181.
} 
be extremely difficult, if not impossible, to prevent the Soviet Union from obtaining control over Greece and over the whole Near and Middle East." ${ }^{19}$

At the same time that Moscow was engaged in a "war of nerves" with Turkey, it was overtly threatening Iran. In the fall of 1945, the Kremlin incited nationalist revolts among the separatist movements in Iran's northern region of Azerbaijan and Kurdistan. When the Iranian government moved to quell the unrest, Soviet forces prevented the government's forces from entering the Russian-occupied zone. Equally disconcerting, they refused to honour their pledge to withdraw their troops after the cessation of the war, as the Anglo-Soviet-Iranian treaty of 1942 had stipulated. ${ }^{20}$ As in the case of Turkey, Moscow demanded territorial concessions from the Iranian government. Only after the American government interceded on Iran's behalf at the United Nations did the Soviet government withdraw its forces. But the damage was done. The U. S. State Department was unnerved by the Soviet actions in Turkey and Iran. The Russians seemed on the move everywhere, a top official warned. "They threatened to 'sweep unimpeded across Turkey and through the Dardanelles into the Mediterranean, and across Iran and through the Persian Gulf into the Indian Ocean."'21 Thus by late 1946, like their British counterparts, American officials had concluded that the Middle East would most likely be the next battleground for escalating Great Power disputes and challenges. As a result of the region's growing importance and its mounting instability, MacCallum's warnings as

\footnotetext{
${ }^{19}$ Dean Acheson, "Memorandum for the Secretary of State," August 15, 1946, in FRUS, 1946, Vol. 7, Near East and Africa (Washington, D.C.: Government Printing Office, 1969), p. 840.

${ }^{20}$ Howard, "The Soviet Union and the Middle East," p. 183.

${ }^{21}$ Loy Henderson, "Memorandum by the Director of the Office of Near Eastern and African Affairs," in FRUS, 1946, Vol. 7, p. 2.
} 
well as her fortunes were, simultaneously advanced. Senior officials in External Affairs decided that a Middle East expert was needed.

In 1947, two events altered MacCallum's career. The first came when the DEA, following the British Foreign Office's lead, decided to allow women to serve as foreign service officers. ${ }^{22}$ This pronouncement afforded MacCallum the opportunity to become a departmental officer and further her role as External Affairs' advisor on the Middle East. The second event was the decision taken by the United Nations to address the Palestine Mandate question. This became MacCallum's defining moment. Everything she knew and felt about Palestine was tested. She was selected as one of four members of Canada's delegation to the United Nations emergency session on Palestine; she was chosen to mentor Justice Ivan Rand, Canada's representative on the United Nations Special Committee on Palestine (UNSCOP); she helped draft Canada's formal statement on UNSCOP's report; and she attempted, in assisting Lester Pearson, the head of the Canadian delegation, to find ways around the division of Palestine into two autonomous regions - the one Jewish, the other Arab. MacCallum was a departmental outsider no more, but her influence was not nearly enough to carry her views into Canadian policy.

In the literature of Canadian foreign policy, Elizabeth MacCallum is a shadowy figure, frequently mentioned but very seldom explained, and never explained fully. Currently, there are only a handful of historical studies that take account of her

22 "Candidates List for Forthcoming Civil Service Examinations for Foreign Service Officers 1 and 2," March 10, 1947, External Affairs Records, LAC, RG 25, Vol. 1054, File: 6-F: "Recruitment of Women as Foreign Service Officers in External Affairs." By May 26, 1947, five women had successfully navigated the written and oral examination to become Canada's first female foreign service officers. 
contribution and Canada's initial foray into Middle Eastern politics. ${ }^{23}$ None of them explain MacCallum's role in Canada's Middle policy in all of its complexity. The paucity of scholarship regarding MacCallum is consistent with the overall scarcity of CanadianMiddle East historiography. According to the bibliography of the Canadian Institute of International Affairs (CIIA), only 1.4 percent of all the articles, essays, dissertations, and books written about Canadian foreign relations during the period from the Second World War to the mid-1990s addressed Canada's relations with the Middle East. Of the CIIA's 228 entries on Canada and the Middle East, only 24 deal with Canada's actions and policies regarding the Palestine question. ${ }^{24}$

There are reasons for the "serious gaps in the academic literature and an absence of documented institutional memory among scholars and practitioners" ${ }^{25}$ regarding Canada and the Middle East. First and foremost, Canadian scholars have tended to interpret the Middle East not for itself, but through the lens of other interests. International historian Norman Hillmer has suggested that Canada's foreign policy -

23 See: Zachariah Kay Canada and Palestine: The Politics of Non-Commitment (Jerusalem: Israel Universities Press, 1978); Anne Trowell Hillmer, "Canadian Policy on the Partition of Palestine, 1947," [Unpublished M. A. Thesis] (Ottawa: Carleton University, 1981); David J. Bercuson, Canada and the Birth of Israel: A Study in Canadian Foreign Policy (Toronto: University of Toronto Press, 1985); Eliezer Tauber, Personal Policymaking: Canada's Role in the Adoption of the Palestine Partition Resolution (Westport, Conn.: Greenwood Press, 2002); David Taras and David Goldberg, (eds.), The Domestic Battleground: Canada and the Arab-Israeli Conflict (Montreal \& Kingston: McGill-Queen's University Press, 1989).

${ }^{24}$ See: Canadian Institute of International Affairs (CIIA), A Bibliography of Works on Canadian Foreign Relations, 1945-1970 (Toronto: CIIA, 1973); A Bibliography of Works on Canadian Foreign Relations, 1971-1975 (Toronto: CIIA, 1977); A Bibliography of Works on Canadian Foreign Relations, 1976-1980 (Toronto: CIIA, 1981); A Bibliography of Works on Canadian Foreign Relations, 1981-1985 (Toronto: CIIA, 1987); A Bibliography of Works on Canadian Foreign Relations, 1991-1995 (Toronto: CIIA, 1998).

${ }^{25}$ Paul Heinbecker and Bessma Momani, "Canada in the Middle East: Ambivalence or Engagement?" in Paul Heinbecker and Bessma Momani (eds.), Canada and the Middle East: In Theory and Practice (Waterloo, ON: Wilfrid Laurier University Press, 2007), p. 2. 
and the literature that tracked it — "functioned almost exclusively in the context of its British and American alignments." Canada was an "alliance member first, last and always." 26 Janice Stein, a professor of international affairs at the University of Toronto, also made the point that Canada's approaches to the Middle East in general, and the Arab-Israeli dispute in particular, are viewed through the prism of Western alliance politics. ${ }^{27}$ Relationships outside the purview of Canada's alliances, and its major alliance partnerships with the United States and the United Kingdom, tend to be regarded as peripheral. Canadian scholarship on international history has failed to chronicle, in any systematic and comprehensive fashion, Canada's role in the Middle East.

The second impediment to the development of a comprehensive Canadian-Middle East historiography has been the absence of graduate programs committed to advancing the study of the Middle East in Canada. Kenneth Stein, a student of contemporary Middle East studies, noted that in "North America and Europe, academic centers for the study of the Middle East developed slowly after World War II." When the history of the Middle East was taught, stated Stein, it was introduced as an adjunct "to the coursework on

\footnotetext{
${ }^{26}$ Norman Hillmer, "The Foreign Policy that Never Was," in Serge Bernier and John MacFarlane (eds.), Canada, 1900-1950, A Country Comes of Age. (Ottawa: Organization for the History of Canada, 2003), p. 152.

${ }^{27}$ Janice Gross Stein, "The Politics of Alliance Policy: Europe, Canada, Japan and the United States face the Arab-Israeli Conflict," in Janice Gross Stein and David B. Dewitt (eds.), The Middle East at the Crossroads: Regional Forces \& External Power (Oakville, ON: Mosaic Press 1983), p. 145. Also see: Janice Gross Stein, "Alice in Wonderland: The North Atlantic Alliance and the Arab-Israeli Dispute," in Steven Spiegel (ed.), The Middle East and the Western Alliance (London: Allen \& Allen, 1982), pp. 4881; Mira Sucharov, "A Multilateral Affair: Canadian Foreign Policy in the Middle East," in David Carment, Fen Osler Hampson, and Norman Hillmer (eds.), Canada Among Nations, 2003: Coping with the American Colossus (Don Mills, ON: Oxford University Press, 2003), pp. 312-331.
} 
Semitic languages, philology, or religion." ${ }^{28}$ At present, only the University of Toronto offers a graduate program in Middle East studies in Canada. ${ }^{29}$ David Bercuson, professor of history at the University of Calgary, highlighted the inadequacies of Canada's Middle East historical studies. In the preface to his study, Canada and the Birth of Israel: A Study in Canadian Foreign Policy, Bercuson stressed how little attention Canadian historians have paid to the Middle East. ${ }^{30}$ "This failure," he remarked, "is a reflection of the weakness of Canadian diplomatic history over the last two decades or so. We have some very good diplomatic historians, but we do not have enough of them ...."31 This fact has not changed since Bercuson's work, written in 1985.

Modest in scale, the historiography of Canada's role in the Palestine conflict has come to very different assessments and conclusions regarding MacCallum's contribution to and influence on Canada's early Palestine policy. Zachariah Kay's Canada and Palestine: The Politics of Non-Commitment was among the first published studies to identify MacCallum and her role in the Palestine question. Throughout his study, Kay asserted that, as External Affairs' sole Middle East expert, MacCallum had "considerable

${ }^{28}$ Kenneth Stein, "A Historiographic Review of Literature on the Origins of the Arab-Israeli Conflict," American Historical Review, Vol. 96, No. 5 (December, 1991), p. 1458.

${ }^{29}$ According to the Canadian Universities and Colleges website, http://www.canadian-universities.net, as of 2013, only the University of Toronto has a graduate program dedicated to Near and Middle East studies. This fact was confirmed by the author in a telephone interview with Anna Sousa, Graduate Administrator of the Department of Near and Middle Eastern Civilizations at the University of Toronto. McGill University, University of British Columbia, University of Alberta, and the University of Toronto offer Bachelor of Arts programs in Middle East studies.

${ }^{30}$ Bercuson, Canada and the Birth of Israel, p. vii.

${ }^{31}$ Ibid, p. viii. 
influence on government thinking on Palestine." 32 He stressed that "there was hardly a document dealing with Palestine during the forties which MacCallum did not write, read or comment on." ${ }^{33}$ Kay insisted that she was "clearly pro-Arab,"34 and stated that her sympathies for the Arabs resulted in an analysis that was flawed and biased. "As a government factor," he wrote, "she was an effective element in preventing any positive attitude towards the Jewish homeland in Palestine."35 Kay also inferred that MacCallum distorted the facts in an effort to give the Arab position a more favourable hearing: "Unlike the Arabs, the Zionists had no high-placed supporter in the External Affairs department. ..."36 Kay's account of MacCallum's influence and her pro-Arab sympathies continued to have a central place in his succeeding studies of Canada and Israel. ${ }^{37}$

Anne Trowell Hillmer's Carleton University M.A. thesis, which appeared in 1981, disputed Kay's findings regarding MacCallum's influence. While acknowledging MacCallum's expertise, Hillmer did not see that knowledge as translating into influence. In rebutting Kay's argument that MacCallum had "considerable influence on the government's thinking on Palestine," Hillmer insisted that this was "overstating

\footnotetext{
32 Zachariah Kay, Canada \& Palestine: The Politics of Non-Commitment (Jerusalem: Israeli University Press, 1978), p. 67.

33 Ibid.

${ }^{34}$ Kay, Canada \& Palestine, p. 67.

35 Ibid.

${ }^{36}$ Ibid, p. 121.

37 Zachariah Kay, The Diplomacy of Prudence: Canada and Israel, 1948-1958 (Montreal \& Kingston: McGill-Queen's University Press, 1996); The Diplomacy of Impartiality: Canada and Israel, 1958-1968 (Waterloo, ON: Wilfrid Laurier University Press, 2010).
} 
MacCallum's influence . . .."38 Hillmer concluded that the "expertise that MacCallum brought to bear on Middle Eastern questions before 1947 served to reinforce rather than to alter the policy which the King Government had long been pursuing . . . It is hard to imagine that the policy would have been different if she had not been there." 39

In David Jay Bercuson's 1985 account, MacCallum was treated as an influential player who shaped the department's early attitude and policy on Palestine. Bercuson argued that, when Canadian officials first stepped into the discussion of the British Mandate in Palestine, in particular with respect to the British White Paper of 1939, it was her reasoned analysis of the Arab-Jewish struggle that was crucial to Canada's decision to remain neutral in the Arab-Zionist dispute until the summer of 1946. But in time, added Bercuson, her influence was superseded by the pragmatic approach to Canadian foreign relations of Lester Pearson, the under-secretary of state for external affairs. ${ }^{40}$

Eliezer Tauber, a Middle Eastern historian at Bar Ilan University in Tel Aviv, was MacCallum's most ardent and thoroughgoing detractor. MacCallum was the central target in Tauber's analysis of Canada's involvement in the Palestine question at the General Assembly in $1947 .{ }^{41}$ In his 1998 article: "Elizabeth P. MacCallum and the ArabIsraeli Conflict," Tauber labelled her an Arab sympathizer and disputed the view that

\footnotetext{
${ }^{38}$ Anne Hillmer, "Canadian Policy on the Partition of Palestine, 1947," pp. 17-18. Also see her "“Here I Am in the Middle': Lester Pearson and the Origins of Canada's Diplomatic Involvement in the Middle East," in David Taras and David H. Goldberg (eds.), The Domestic Battleground: Canada and the ArabIsraeli Conflict (Kingston, Montreal: McGill-Queen's University Press, 1989).

${ }^{39}$ Hillmer, "Canadian Policy on the Partition of Palestine, 1947," p. 19.

${ }^{40}$ Bercuson, Canada and the Birth of Israel, p. 42.

41 Eliezer Tauber, Personal Policy Making: Canada Role in the Adoption of the Palestine Partition Resolution (Westport, Conn.: Greenwood Press, 2002).
} 
MacCallum took a balanced approach to the Palestine question. He accused her of distorting or "deliberately" exaggerating evidence in order to advance her own views and aims. ${ }^{42} \mathrm{He}$ further argued that MacCallum "tried her best to discredit the lobbying activities in favor of partition that were being carried out by both Jews and non-Jews." ${ }^{43}$ Tauber also challenged her expertise as a Middle East authority.

The fact that MacCallum's colleagues in the Canadian Department of External Affairs knew about the Middle East even less than she did, certainly helped her to consolidate her status in their eyes as an expert on region. While MacCallum's expertise is debatable ... she definitely was not a 'bona-fide expert.' 44

Tauber even went as far as to suggest that David Horowitz, a senior officer in the political directorate of the Jewish Agency, had been fooled by MacCallum. Tauber disputed Horowitz's observation that he "found no hostility in her attitude toward us ... [she] had no rooted prejudices." ${ }^{\circ 5}$

Beginning in 1973, following Israel's decisive victory over the combined military forces of Egypt, Syria, and Jordan, the intellectual foundation that had shaped much of the scholarly literature on Palestine was challenged. A younger generation of Jewish and Arab academics confronted the conventional interpretations of Zionist and Arab history. In Israel, a "new" school of Jewish scholars, founded and led by Benny Morris, Avi Shlaim, and Ilan Pappé, questioned the mainstream Zionist historiographical record, and

\footnotetext{
${ }^{42}$ Ibid, pp. 91-93.

${ }^{43}$ Eliezer Tauber, "Elizabeth P. MacCallum and the Arab-Israeli Conflict," Journal of Israeli History: Politics, Society, Culture, Vol. 19, No. 2 (1998), p. 99.

${ }^{44}$ Ibid, pp. 106-107.

${ }^{45}$ Ibid, p. 99.
} 
its claims regarding the intransigence of the Arabs. ${ }^{46}$ Armed with recently declassified U. S. State Department records, Israeli foreign affairs documents, and previously unseen accounts and interviews, the new school's historians, sociologists, and political scientists began to reshape Israel's traditional historical narrative regarding the causes, course, and results of the Arab-Jewish conflict. The new school's adherents were unwilling to accept Zionist claims that the Jews were the benign victims of Great Power politics and Arab malice. Instead, they "portrayed Israel as a strong, deliberate state that aggressively exploited opportunities to expropriate land and gain strategic advantage at the Arabs expense." $" 47$

This reinterpretation was strongly opposed in Israel by Zionist and post-Zionist historians, who rejected the new school's conclusions and assessments. By the late 1990s, the dispute over the nation's past had erupted onto the pages of virtually every international journal and periodical dealing with the Middle East dispute. The new historians depicted the imperialist ambitions of the Israeli state and the unwillingness of the Zionist leadership to find a solution to the Arab problem. ${ }^{48}$ The Zionist and post-

46 Neil Caplan, "Zionism and the Arabs: Another Look at the 'New' Historiography," Journal of Contemporary History, Vol. 36, No. 2 (April, 2001), p. 348.

${ }^{47}$ Jonathan Isacoff, "Writing the Arab-Israeli Conflict: Historical Bias and the Use Of History and Political Science," Perspectives on Politics, Vol. 3, No. 1 (March, 2005), pp. 73-74. For an expanded description of his views, see Jonathan Isacoff, Writing the Arab-Israeli Conflict: Pragmatism and Historical Inquiry (Lanham, MD: Lexington Books, 2006), Chapter 2, Writing the Arab-Israeli Conflict.

${ }^{48}$ See: Chaim Isaac Waxman, "Critical Sociology and the End of Ideology in Israel," Israeli Studies, Vol. 2, No. 1 (Spring, 1997), pp. 194-210; Benny Morris, "Palestinian Identity: the Construction of Modern National Consciousness," Israeli Studies, Vol. 3, No. 1 (Spring, 1998), pp. 266-272; Gordon W. Rudd, "The Israeli Revisionist Historians and the Arab-Israeli Conflict - Part One: From the Founding of Zionism to the 1967 War," The Journal of Military History, Vol. 67, No. 4 (October, 2003), pp. 12631270; Ilan Pappé, "Humanizing the Text: Israeli 'New History' and the Trajectory of the 1948 Historiography," Radical History Review, Issue 86 (Spring, 2003), pp. 102-122; Ilan Pappé, "The PostTerritorial Dimensions of the Future Homeland in Israel and Palestine," Comparative Studies of South 
Zionist schools, in response, attacked the new school's assertions with equal vigour, charging them with a blatant and intentional misinterpretation of the historical facts. ${ }^{49}$

Arab scholars, and in particular Palestinian historians, also sought to reshape national and international narratives following the humiliating Arab defeats of 1967 and 1973. ${ }^{50}$ The newly created Union of Arab Writers (UAW) called for a reassessment and rewriting of Arab history. In 1987, the Union announced the formation of the Higher Arab Board with a plan to develop an "Arab philosophical school of historical interpretation' which would be a complete departure from all earlier historical schools, Western and Eastern, and which would explore 'Arab-Islamic historic truth." ${ }^{, 51}$ No longer did Palestinian historians see Arab historiography as serving the interests of the national Palestinian movement. ${ }^{52}$ Using the scientific methods of western secular scholars and the newly released Israeli documents, and in collaboration with the new Israeli school, Palestinian scholars disassociated themselves from Pan-Arabist historiography and adopted a "particularistic character" in their studies. This approach was less religious, less combative, and more critical of the Arab World. Its aim, however, remained to prove

Asia, Africa and the Middle East, Vol. 23, No. 1 \& 2 (2003), pp. 224-233; Joseph Massad, "The Persistence of the Palestinian Question," Cultural Critique, No. 59 (Winter, 2005), pp. 1-23.

49 See: Rafael Medoff, "In Recent Trends in the Historiography of Zionism: A Review Essay," Modern Judaism, Vol. 15, No. 1 (February, 1995), pp. 95-101; Arye Naor, “A Matter of Distoriography: Efraim Karsh, the 'New Historians' of Israel, Their Methodology and Perspective,' Israeli Studies, Vol. 6, No. 2 (Summer, 2001), pp. 139-150; Samera Esmeir, “1948: Law, History, Memory,” Social Text, Vol. 21, No. 2 (Summer, 2003), pp. 25-48; Nahum Karlinsky, “Beyond Post-Zionism," Israeli Studies, Vol. 9, No. 3 (Fall, 2004), pp. 169-181; Assaf Likhovski, "Post-Post Zionist Historiography," Israeli Studies, Vol. 15, No. 2 (Summer, 2010), pp. 1-23.

${ }^{50}$ Ulrike Freitag, "Writing Arab History: The Search for the Nation," British Journal of Middle East Studies, Vol. 21, No. 1 (1994), p. 19.

51 Ibid.

52 Rachel Maissy-Noy, "Palestinian Historiography in Relation to the Territory of Palestine," Middle East Studies, Vol. 42, No. 6 (November, 2006), p. 901. 
"the rights of the Palestinians to the territory of Palestine," and deny the rights of the Jews to it."53 They, therefore, attempted to challenge Israel's religious, legal, demographic, and cultural claims to Palestine. Instead, they sought to construct a positive Palestinian narrative that could be plausibly presented to the world.

The new Palestinian Arab and Jewish schools have raised, explicitly and implicitly, many of the questions that MacCallum herself had asked about the Middle East and Palestine. Was it impossible for Arabs and Jews to come together in a settlement of their differences? Was the partition of Palestine not the worst of all possible options? Did the Great Powers not operate solely for themselves and in their own interests? Was self-determination not the proper position from which to proceed? Did Canada work though the Palestine problem basing their thinking on Great Power logic rather than on the dynamics of a complex region?

This thesis employs a wide corpus of primary sources: personal papers, memoirs, government documents, and non-governmental records. The personal papers include those of the MacCallum family, Mackenzie King, Louis St. Laurent, and Lester B. Pearson. Of special note among the personal collections were Anne Hillmer's papers, which contain her research notes and documents on Middle East questions, generously given to me by her husband. Government documents represent the "official" position of Canada and its international counterparts, but also the internal debates of policy-makers. This study has used the records of the Department of External Affairs, the Privy Council

\footnotetext{
${ }^{53}$ Ibid, p. 890 .
} 
ArchivesOffice, and the Public Service Commission of Canada, all of which are housed at Library and Archives Canada. Also employed were official British and American records, which were crucial in explaining Great Powers' perceptions, motivations, and intentions.

Inter-governmental and Non-Governmental Organizations (NGO) documents utilized here include the records and reports of the Foreign Policy Association, World Peace Foundation, and the Canadian Legion's Educational Services; these were essential in documenting the work of Elizabeth MacCallum prior to her joining the Department of External Affairs. Newspapers, such as the New York Times, The Times (London), and The Globe and Mail (Toronto), lent contemporary perspectives, as well as context and colour, to the events described in this thesis. I am also grateful to Queen's University Archives for allowing me to consult their alumni records and its oral history project, which included a lengthy recorded interview with Elizabeth MacCallum.

Chapter 1, An All-Embracing Imperialism, 1925-1941, delves into MacCallum's formative period of Middle East writing, the most productive period in her scholarly life, during which she produced numerous articles and three books on the Middle East. It was during this period that the intellectual foundation of her approach to the region was consolidated. In examining her articles and books, the chapter pieces together her views of the Middle East and portrays her growing trepidation about the interference of the Great Powers in Middle East affairs and her belief that the imperial policies of France and Great Britain were ruinous for the region. The chapter also examines MacCallum's 
concerns about Arab-Zionist tensions, and the imminent threat that they represented to the region and to the international community as a whole.

Chapter 2, An Insider's (and a Male's) Department of External Affairs, 19421943, investigates MacCallum's first year of service in the Department of External Affairs. A narrow and politics-driven department is uncovered, where policy was formulated based on the prime minister's domestic priorities, and where gendered relations prevailed. The chapter, moreover, depicts how the department's androcentric culture dictated the criteria for the organization's recruitment, hiring, and posting practices. These were among the obstacles that held MacCallum back during the war years.

Chapter Three, A Voice Beginning to be Heard, 1944-1945, reveals MacCallum's intellectual and political skills, and the growing recognition of them by the senior officials of the Department of External Affairs. After only two years of service with the department, she was given an opportunity to prepare the government's first public response to Canadian Zionist demands for the repudiation of the British 1939 Palestine policy, demonstrating the value of having a Middle East specialist in the External Affairs department. MacCallum's analysis of the problem concentrated on the growing AngloAmerican differences concerning Palestine, the rising Arab-Jewish-British tensions in Palestine, and Canada's attempts to address the international refugee problem.

Chapter Four, San Francisco, MacCallum and Canada at the Margins, 1945, investigates MacCallum's attitude towards the Great Powers' efforts to construct an International Trusteeship system during the San Francisco Conference, which founded 
the United Nations Organization in 1945. Her attendance as a special advisor to the Canadian delegation might have meant participation in the building of an equitable and stable postwar system, and the demonstration of her comprehensive knowledge of the League's Mandates System and International Trusteeship. Yet Canada was at the margins of the conference and so too was MacCallum. All she could do was observe the Great Powers as they carved the world into zones of control and influence. The chapter relates MacCallum's concerns about the Great Powers and their management of the Trusteeship system, and the Canadian delegation's stance on both.

Chapter Five, Palestine and MacCallum's Warnings, 1945-1946, covers a period of intensifying Anglo-American discord over the fate of the British Mandate in Palestine and of the Jewish survivors of the Nazi Holocaust. U. S. President Franklin Delano Roosevelt's pragmatic international politics were replaced by Harry Truman's morallycentered orientation towards the Middle East. The Palestine impasse was a priority for Truman, whose policy agenda conflicted with Britain's Labour government's program for Palestine, which was shaped by the previous government's 1939 policy regarding its Mandate in Palestine. The question of Jewish immigration to Palestine was the point of central friction between the two Western powers. In Canada, Jewish demands for unrestricted immigration to Palestine forced the Department of External Affairs to react. MacCallum took a hand in investigating the Palestine question. She was asked to prepare three memoranda outlining the European refugee problem and recommending a policy for dealing with it. The chapter explores MacCallum's memoranda and her attitude 
towards the problems of Jewish resettlement against the background of Anglo-American tensions relating to a Jewish state in Palestine.

Chapter Six, Pearson's Triumph, MacCallum's Tragedy 1946-1947, examines the Palestine question as it took centre stage in international affairs and the Cold War. With the increasing violence in Palestine among the Palestinian Arabs, the Jews, and British, and deteriorating Anglo-American relations over the fate of surviving European Jewry, Canada and the United Nations were drawn into the Middle East morass. The chapter investigates the emergency session of the General Assembly, the United Nations Special Committee on Palestine (UNSCOP), the behind-the-scenes deliberations and lobbying, the vote in the Assembly on the plan for the partition of Palestine on November 29, 1947, and Lester B. Pearson's proposed compromise plan for the partition of Palestine. The chapter's analyses highlight the struggle between Elizabeth MacCallum's vision of a balanced and fair outcome for Palestine, and Pearson's diplomacy of "realpolitik." The triumph of Pearson and partition was, for MacCallum, a tragedy for the Middle East. 


\section{Chapter 1 An All-Embracing Imperialism, 1925-41}

In early 1925, while completing the third year of her doctoral studies in modern European history at Columbia University in New York, Elizabeth MacCallum was encouraged by Edward Mead Earle, former chairman of the History department at Columbia University, to join his Foreign Policy Association's (FPA) newly established Research Department. Predicated on the idea that an educated public opinion was a regulating agency in a democracy, and an offset to private interests that sought to influence American foreign policy, the Association established a research department consisting of an eclectic group of journalists and historians. Their principal role was to produce impartial information about world affairs and to furnish journalists, university students, and professors of international relations with data concerning America's relationships with other countries and peoples. In the early post-First World War period, suggested Donald Phillips Dennis, FPA's official historian, "reliable information on foreign affairs was hard to come by." ${ }^{54}$ The Association wanted to educate Americans about global developments that affected them and shaped their nation's foreign policies.

\section{A Balanced Skepticism}

For MacCallum, the FPA position offered an opportunity to address her shortterm requirement to make a living and her long-term ambition to be a useful citizen. Like her older brother Lyman and sister Edith, the younger MacCallum was compelled, from time-to-time, to leave her studies and seek temporary employment. Satisfying though

\footnotetext{
${ }^{54}$ Donald Phillips Dennis, Foreign Policy in Democracy: The Role of the Foreign Policy Association (New York: Foreign Policy Association Global Visions Books, 2003), p. 59.
} 
these positions turned out to be, these interruptions had forced her away from her studies and further from her academic goal of studying the Middle East.

The Association opened up avenues previously unavailable to MacCallum. The FPA was a heady prospect: "the electric atmosphere of the exchanges . . the excitement of rubbing elbows with the best minds of the era; the thought that, maybe, just maybe, some good could be done in an already very dangerous world." 55 It was an opportunity to study and work with her mentor Edward Earle. Like MacCallum, he had spent a large portion of his life in Turkey. His writings paid particular attention to early twentieth century European imperialism and its toxic impact on the Middle East region. ${ }^{56}$ Their mutual interests and friendship shaped much of MacCallum's early writings. Moreover, the FPA offered her the potential to promote a greater understanding of the rich history of the Middle East among Americans, and provided her the prospect of making a contribution to world peace — an aim that all the MacCallum children embraced. The former Canadian ambassador to Saudi Arabia and Yemen, Michael Shenstone, recalled that her writing of "foreign policy was not a way of just earning a living; it was a way of trying to make certain parts of the world a better place, a just place, a more humane

\footnotetext{
${ }^{55}$ Anne Trowell Hillmer, “A Remembrance: Elizabeth Pauline MacCallum,” bout de papier, Vol. 3, No. 2 (Summer, 1985), p. 14.

${ }^{56}$ Edward Meade Earle, Turkey, The Great Powers and the Bagdad Railway: A Study in Imperialism (New York: Macmillan Co., 1923); "The Importance of the Near East in Problems of Raw Materials and Foodstuffs," Annals of the American Academy of Political and Social Sciences, Vol. 112 (March, 1924), pp. 183-186; "The Turkish Petroleum Company: A Study in Oleaginous Diplomacy," Political Science Quarterly, Vol. 39, No. 2 (June 1924), pp. 265-279; Modern France: Problems of the Third and Fourth Republics (Princeton, N. J.: Princeton University Press. 1951).
} 
place." ${ }^{57}$ With no illusions about what this would do to her doctoral studies, MacCallum accepted Earle's offer. It was time to move from the theoretical to the practical.

MacCallum's job description was in keeping with the Association's overall mission to remain nonpartisan in all of its activities. Each researcher-writer in turn was responsible for reporting on developments and issues relating to a particular geographic region of the world. MacCallum was given the Middle East. ${ }^{58}$ In 1925, it was undoubtedly among the most problematic of the regions to cover as a scholar; it required a comprehensive understanding of Asia Minor, the history of the Arab people and Islam, the European presence, Political Zionism, and the League of Nations' newly created Mandate System. In order to cover the region's overarching complexities adequately, MacCallum was given significant latitude in her reporting. Although encouraged to choose her own subject matter, and determine what she thought relevant, ${ }^{59}$ her work was expected to conform with the organization's academic approach.

There was no room for polemics or sophistry. The FPA discarded cleverly conjured up and one-sided arguments. Instead, the Association sought more balanced and objective work, wanting recognition as an organization devoted to expertise and scholarship. The Research Department required that all articles be vetted through a peerreview process. Draft articles were sent out to people who often had different views from

\footnotetext{
${ }^{57}$ Michael Shenstone, "Eulogy to Elizabeth P. MacCallum,” Hillmer Papers (July 10, 1985).

58 Royal Institute of International Affairs (RIIA), The Middle East: A Political and Economic Survey (London: RIIA, 1954), p. 1.

59 Diane Gordon, “Interview with Elizabeth MacCallum," Oral History Project, Queen's University (October 15, 1977).
} 
the author. MacCallum later admitted that the challenges of this process were considerable.

If you have been dealing with an issue where there were perhaps four or five different . . . strongly held views, you must find a leading proponent of each view, send him or her copies of your draft and wait for the criticism before you actually hand it in, and . . . balance them against each other, and not until that process has been finished will this be considered [completed]. ${ }^{60}$

This approach fit MacCallum's intellectual style and personality. As she recollected in her interview with Diane Gordon in 1977, "for a person [like me] who wants to be objective in her work, instruction of this kind is far more agreeable than instructions to build up such-and-such a case, which was the fate of many a person who had gone through Columbia." $" 11$ The peer-review process dovetailed with the education that she had received at home. Throughout her home studies, she had frequently been challenged by her parents and siblings to defend her ideas and beliefs. Her father, in particular, demanded that her learning must incorporate a disciplined, sceptical, combative, and at times, contrarian style. Like her father and brother Lyman, she embraced a scholarship that required a "complete abstention from tyranny over other minds." 62

Another feature of MacCallum's intellectual development, as a thoughtful and disciplined scholar, was her ability to distill knowledge from informal settings. Throughout her academic life at Queen's and Columbia Universities, and her work at the

\footnotetext{
${ }^{60}$ Ibid.

${ }^{61}$ Ibid.

${ }^{62}$ Padwick, Call to Istanbul, p. 5.
} 
FPA, MacCallum often invited friends and colleagues, who had recently returned from the Middle East, to her home to discuss regional affairs. Her guests routinely brought to her unfiltered information about developments in Turkey, Palestine, and Syria, and shared their concerns about the events they witnessed. MacCallum also attended the FPA's-sponsored "luncheon series," which provided her with an opportunity to meet, interact, and learn from the top people in her field at the Astor Hotel. Countless leaders in international relations, including Canada's under-secretary of state for external affairs, $\mathrm{O}$. D. Skelton, attended the luncheon series and shared their concerns about world developments. "These debates," recalled MacCallum, were an "intellectual lifeline for those of us who wrote about international affairs." ${ }^{93}$

\section{MacCallum and the Imperialists}

For more than a decade, beginning in 1925, MacCallum's wrote extensively on the Middle East. In more than thirty essays and articles, and three books, a singular and steady impulse emerged that would be the intellectual root of much of her later work as a public servant and diplomat. Strongly influenced by American philosopher and historian Hans Kohn, and her mentor Edward Meade Earle, her work expressed the belief that the Middle East's landscape of the 1920s and 1930s — the rise and intensification of Arab religious and political nationalism; the ever-increasing clashes between Arabs and Zionists in Palestine; the region's slow and erratic economic development; and the imposition and administration of the League of Nations' Mandate System - were manifestations of European imperial-colonial rivalries. Her writing also reflected what

\footnotetext{
${ }^{63}$ Gordon Interview.
} 
Kohn called the "new, world-embracing imperialism." 64 Kohn suggested that, in principle, this new, world-embracing imperialism was similar to the earlier types of imperialism in that it remained an expression of domination. However, Kohn believed technological advancements had altered the ways in which a powerful state could exercise that domination. He stated that advanced nations now had the ability to utilize modern developments in communications and industry. Thus they had the capacity to dominate more completely. ${ }^{65}$

As a student of modern European history, MacCallum recognized the importance of the Middle East as a battleground for imperial competitions. This view is plainly expressed in her 1935 article "The Arab Nationalist Movement." For MacCallum, the central protagonist in the struggle for control of the region among the European imperial powers was Great Britain. ${ }^{66}$ In the nineteenth century, Britain had become the most active imperial power. The British had taken over Cape Colony in South Africa from the Dutch East India Company, made New Zealand a British colony in 1840, and consolidated their hold over the Malay States, Hong Kong, Sierra Leone, Gambia, Lagos, and the Gold Coast. From their bases in British India, the British had expanded into the Punjab, Sind, Berar, Oudh, Kashmir, and Lower Burma. Commencing from Cape Colony, the British expanded into Basutoland, Griqualand, and Natal. In the Middle East, they had been

\footnotetext{
${ }^{64}$ See: Hans Kohn, A History of Nationalism in the East (New York: Harcourt, Brace, and Co., 1932); Hans Kohn, Nationalism and Imperialism in the Hither East (New York: Harcourt, Brace, and Co., 1932).

${ }^{65}$ Kohn, Nationalism and Imperialism in the Hither East, p. 50.

${ }^{66}$ Over half of the articles and essays written by MacCallum for the FPA focused on British interests or their diplomatic activities.
} 
particularly active. London wrestled with France, Russia, Italy, and Germany for preeminence in the Persian Gulf and Turkish Arabia.

Throughout the eighteenth and nineteenth centuries, Britain's European rivals tried to dislodge Britain from the Persian Gulf and Red Sea areas. Russia's assimilation of northern Persian territories and the acquisition of markets and influence in the latter half of the eighteenth century confirmed Britain's fear that Russia intended to build a vast Oriental empire, which included India and a warm water port in the Mediterranean. ${ }^{67}$ The French also tried to seize the Persian Gulf and Red Sea in order to invade British India and bring England to its knees. One by one, the Russians, French, and Italians tried and failed to displace Britain. The British, as MacCallum pointed out, consolidated their control of all but a few sections of the southern coastal territories of the Arabian Peninsula by a series of treaties with individual sheikhs and princes. ${ }^{68}$ Throughout the nineteenth century, the strategic concerns of Middle Eastern dominance remained as steady as the North Star in British imperial policy.

By 1899, noted MacCallum, Germany began to replace Russia as Britain's principal rival in Turkish Arabia and the Persian Gulf. ${ }^{69}$ The Germans had got a foothold

${ }^{67}$ Philip Willard Ireland, Iraq: A Study in Political Development (London: Jonathan Cape Ltd., 1937), p. 38. Also see: J. De V. Loder, The Truth about Mesopotamia, Palestine \& Syria (London: George Allen \& Unwin Ltd., 1923).

${ }^{68}$ MacCallum, "The Arab Nationalist Movement," p. 52, footnote 9. MacCallum noted that this treaty system included the Sheikhs of the Hadhramaut, the Sultan of Muscat, the Sheikhs of Trucial Oman and the rulers of Qatar, Kuwait, and the Bahrain islands. For a full background, see: A. T. Wilson, The Persian Gulf (Oxford: Clarendon Press, 1928); Halford L. Hoskins, "Background of the British Position in Arabia," Middle East Journal, Vol. 1, No. 2 (April, 1947), pp. 137-147.

${ }^{69}$ MacCallum, "British Interests in Mesopotamia," p. 2. Also see: Sir Fredrick Maurice, "British Policy in the Mediterranean," Foreign Affairs, Vol. 5, No. 1 (October, 1926), p. 103. 
in Mesopotamia when they had been awarded the concession by the Sultan's court to build the Baghdad Railway from Anatolia to the Persian Gulf. In "British Interests in Mesopotamia," MacCallum described Britain's concerns about this penetration and its fear that a German-controlled railway to the Persian Gulf would pose a serious threat to their interests in the region. ${ }^{70}$ Germany threatened Britain's plans to build a PalestineTransjordan-Iraq route to India and thus to undermine the strategic security of British India. ${ }^{71}$ "Great Britain took steps to protect the head of the Persian Gulf against German encroachments," MacCallum wrote, by preventing the railway line from going beyond Basra, 100 miles from the Persian Gulf. ${ }^{72}$

So great was the attention that the British gave to German economic and military growth that predictions of Germany's overtaking of Britain as the world's pre-eminent power came to be a staple item of British politics in the two decades before World War One. Lord Curzon, the early twentieth century viceroy of India, and later secretary of state for foreign affairs, echoed the concern about Germany when he called for greater British control of the Persian Gulf and its surrounding territories, and the strengthening of India's defences. ${ }^{73}$

Mesopotamia, which ran north from the head of the Persian Gulf, and was sandwiched between Persia, the Arabian Peninsula, Syria, and Transjordan, was the focal

\footnotetext{
${ }^{70}$ Ibid.

71 Elizabeth MacCallum, "Turco-Iraq Boundary Dispute," Foreign Policy Association's Editorial Information Service (FPAIS), No. 3, Series 1925-1926 (November 5, 1925), p. 2.

${ }^{72}$ Elizabeth MacCallum, "British Interests in Mesopotamia," FPAIS, No. 4, Series 1925-26 (November 17, 1925), p. 2.

${ }^{73}$ Ireland, Iraq: A Study in Political Development, p. 40.
} 
point for Anglo-German competition in the earlier part of the twentieth century. ${ }^{74}$ Its strategic value was abundantly clear to MacCallum: ${ }^{75}$ the valleys of the Tigris and the Euphrates were natural highways from Syria to the Persian Gulf, and thereby, to the Indian Ocean. So strategically placed were the valleys that British leaders consistently regarded them as commercial and political extensions of the Persian Gulf, in whose politics India's security, integrity, and safety resided. ${ }^{76}$ To her description of the AngloGerman rivalry, MacCallum added oil — the common currency in the struggle for control. The British-controlled Anglo-Persian Oil Company (APOC), which had a controlling interest in development of Mesopotamian oil fields, was acquired by the British Admiralty in 1913 for the purpose of assuring oil supplies. ${ }^{77}$ This was challenged in 1914 by Dutch and German interests in the Turkish Petroleum Company, which had been promised a long-term concession by the Turkish Sultan for the partially surveyed oil fields of Baghdad and Mosul. ${ }^{78}$ Preliminary survey reports revealed Mesopotamia's real

\footnotetext{
${ }^{74}$ F. S. Naiden, "Lines in the Sand," The Wilson Quarterly, Vol. 31, No. 1 (Winter, 2007), p. 54. Naiden defined the territory commonly referred to as Mesopotamia as Turkish Iraq, due to the fact that topographically Mesopotamia is the valley between the Tigris and Euphrates Rivers. However, most historians use "Mesopotamia to represent the whole territory." Thus, this paper will use the term Mesopotamia until its name was formally changed to the Kingdom of Iraq.

${ }^{75}$ MacCallum wrote four articles on Mesopotamia: "The Turco-Iraq Boundary Dispute," FPAIS, No. 3, Series 1925-1926 (November 5, 1925), pp. 1-8; "British Interests in Mesopotamia," FPAIS, No. 4, Series 1925-1926 (November 17, 1925), pp. 1-8; “American Oil Interests in Mesopotamia," FPAIS, Vol. 2, No. 6 (May 22, 1926), pp. 68-78; "Iraq and British Treaties," FPAIS, Vol. 6, No. 12 (August 20, 1930), pp. 225-246; .

${ }^{76}$ Ireland, Iraq: A Study in Political Development, p. 49.

${ }^{77}$ MacCallum, "British Interests in Mesopotamia," p. 1.

${ }^{78}$ Edward Peter Fitzgerald, "France's Middle Eastern Ambitions, the Sykes-Picot Negotiations, and the Oil Fields of Mosul, 1915-1918," The Journal of Modern History, Vol. 66, No. 4 (December, 1994), p. 700. The Ottoman government, which administered the area, commissioned European geologists to investigate the petroleum deposits found in the Vilayet of Mosul.
} 
value to French, German, and British officials. ${ }^{79}$ MacCallum noted that: "Its reputed wealth in oil reserves has caused British oil promoters to regard the [Mosul] Vilayet as a prize of special worth." 80 The British Foreign Office recognized the importance of oil to Great Britain's and Germany's broader strategic interests in the region, and saw unquestionably, the possibility of military confrontation. ${ }^{81}$ The region's value partially stemmed from the feverish world race to find and secure oil, the life blood of any forward-thinking naval policy.

Most concerning to the British, MacCallum pointed out, was the huge German ship-building programme, which called for the construction of a fleet of battleships and large armoured cruisers. In 1906, the British Admiralty began a six-year crash program that modernized its existing fleet and commissioned the construction of new dreadnoughts and cruisers. ${ }^{82}$ By converting the existing British fleet from coal to oil, the range and speed of the Royal Navy's ships would be dramatically increased. As First Lord of the Admiralty Winston Churchill later stated: "In equal ships oil gave a large excess of speed over coal. It enabled their speed to be attained with far greater rapidity. It gave 40 per cent greater radius of action for the same rate of coal." 83 Thus, the refit made

\footnotetext{
${ }^{79}$ MacCallum, "British Interests in Mesopotamia,” p. 2.

${ }^{80}$ MacCallum, “The Turco-Iraq Boundary Dispute,” p. 2.

${ }^{81}$ MacCallum, "British Interests in Mesopotamia," p. 2.

82 The dreadnought was the predominant type of 20th-century battleship. The first of the kind, the British Royal Navy's HMS Dreadnought, had such an impact when launched in 1906 that similar battleships built after her were referred to as "dreadnoughts," and earlier battleships became known as predreadnoughts.

83 Henry Longhurst, Adventure in Oil: The Story of British Petroleum (London: Sidwick and Jackson, 1959), p. 50. Also see: Viscount Hythe and J. Leyland (eds.), The Naval Annual, 1914 (Portsmouth, Britain: J. Griffith and Co., 1914), pp. 76, 83. During the years between 1906 and 1912, an intense headto-head competition between the two powers took place in the building of modem capital ships. During
} 
Britain's existing Grand Banks fleet more competitive with the new German surface fleet, until the new British warships were ready to come on line.$^{84}$ MacCallum drew attention to the crucial technological shift to oil of the Royal Navy, the bulwark of Britain's security and the shield of its imperial power. This innovation required a secure and steady flow of oil, if Britain was to maintain its maritime supremacy and command of the sea. ${ }^{85}$ The importance of securing Mesopotamian oil rights was therefore obvious.

Britain's long tenure as the dominant European power in Turkish Arabia and the Persian Gulf was sorely tested during the decade leading up to and during the Great War. Germany's influence and power in the region grew rapidly and significantly. While the basis of British policy was to maintain the status quo, ${ }^{86}$ the Germans no longer recognized or tolerated British dominance in the Middle East. This led to a flurry of diplomatic negotiations and agreements, reflecting the competing European powers' continued efforts to press for better positions in Mesopotamia and the Persian Gulf. The most significant of these deals was the Anglo-French agreement of 1904, generally known as the Entente Cordiale. For those inside both the Quai d'Orsay, France's foreign office, and Britain's Foreign Office, the Entente was a "shotgun marriage made necessary

this six-year period, Britain launched 29 capital ships and Germany launched 17 ships. Naval expenditures in both countries soared to pay for this arms build-up: Germany's naval budget practically doubled, and Britain's naval estimates increased by over forty percent. Another result of their rivalry in naval armaments was a deterioration in relations between the two countries, as arms control efforts failed to restrain the competition.

${ }^{84}$ Ibid.

${ }^{85}$ Elizabeth MacCallum, "British Interests in Mesopotamia," FPAIS, No. 4, Series 1925-26 (November 17, 1925), p. 2.

${ }^{86}$ Gilbert Murray, The Foreign Policy of Sir Edward Grey, 1906-1915 (Oxford: Clarendon Press, 1915), p. 48. 
because Germany's finger appeared to be inching closer to the trigger." ${ }^{17}$ The Entente recognized Anglo-French overseas interests - France's empire in North Africa, and Britain's in the Middle East, particularly India. Both foreign offices saw the Entente as a modus vivendi, designed to deter further German penetration into the Middle East, and discourage the Turkish sultan from animating further European competitions. Yet, instead of securing a temporary alliance, the Anglo-French entente appeared to intensify the suspicions between the two powers. ${ }^{88}$ This would play a particularly important role during the First World War, with respect to Syria, Palestine, and Mesopotamia.

\section{The Great War and Great Power Maneuverings}

When MacCallum wrote about the First World War, it was to provide historical context for contemporary Middle East issues in her time. Her brief inquiries into the region's wartime experience provide valuable insights about her perceptions of British imperial power, and how the war affected the Arab World. MacCallum's analysis, more precisely, focused on how Britain endeavoured, militarily and diplomatically, to secure its economic and political interests in the region, and to neutralize its rival. In her overview of Britain's military campaign in Mesopotamia, for instance, she proposed that the rapid deployment of a 50,000 British-Indian force had more to do with safeguarding economic and strategic interests than with particular military operational considerations. ${ }^{89}$ For the British Empire, political priorities dictated operational logic. Britain's opening

\footnotetext{
87 James Barr, A Line in the Sand: Britain, France and the Struggle for the Mastery of the Middle East (London: Simon \& Schuster, 2011) pp. 13, 15. Also see Murray, The Foreign Policy of Sir Edward Grey, Chapter 3, The Entente with France.

${ }^{88}$ France tried to penetrate Mesopotamia by attempting to build a French-dominated railway from Syria to Mesopotamia.

${ }^{89}$ MacCallum, "British Interests in Mesopotamia," p. 2.
} 
salvo in the First World War's Middle East campaign was to secure the oil refineries at Abadan, on the southern coast of Persia near Basra. ${ }^{90}$

MacCallum contended that the Britain's military strategy consisted of three specific goals: to protect its Persian oil interests, which were situated near the PersianMesopotamian border; to ensure Britain's predominance in the Persian Gulf at war's end; and to secure its future oil interests in Mesopotamia. ${ }^{91}$ Equally important, insisted MacCallum, was Britain's determination effectively to eliminate the Russians, Germans, and French from any significant role in the Persian Gulf, Mesopotamia, and especially, the Vilayet of Mosul, which was in Ottoman territory. ${ }^{92}$ In the case of Mosul, reported MacCallum, Britain's re-evaluation of its strategic and economic value led to a change in its military and political policy towards Mosul. ${ }^{93}$ Reports from German and French geologists, who had surveyed the region before the war, stated that Mosul possessed "the

${ }^{90}$ Barr, A Line in the Sand, p. 18.

${ }^{91}$ Elizabeth MacCallum, "Iraq and the British Treaties," FPAIS, Vol. 6, No. 12 (August 20, 1930), p. 228.

92 MacCallum, “British Interests in Mesopotamia,” p. 2. A significant portion of MacCallum's analyses for the FPA focused on Mosul. Its importance did not lay in its geo-strategic value or Britain's desire to integrate it into Mesopotamia after the war, but in the British Empire's special economic interests in its oil. She would devote three articles exclusively to its fate. In "The Turco-Iraq Boundary Dispute" and "British Interests in Mesopotamia," she described the continuing problem of international rivalries and competitions for control of the Middle East. More specifically, she explored Britain's efforts to seize on behalf of the Kingdom of Iraq — the vilayet of Mosul and its oil rights. An analysis of the Mosul dispute enabled MacCallum to strip away the façade of Britain's "good intentions," and lay bare their true interests: the securing Mosul for Britain. Her analysis also unveiled the imperial practices of European powers, her growing suspicion of European intentions, and Britain's role in shaping the political and economic fortunes of the Middle East. Also see: V. H. Rothwell, "Mesopotamia in British War Aims, 1914-1918," The Historical Journal, Vol. 13, No. 2, (June, 1970), pp. 273-294.

93 MacCallum, "British Interests in Mesopotamia," p. 2. Under the terms of the Sykes-Picot Agreement, Mosul was designated to be within the French sphere of influence. The agreement was altered and in return for giving up Mosul, France was given full sovereignty over Cilicia, southern Armenia, and the Syrian coast, together with zones of influence extending inland from Syria to the Persian frontier. 
largest undeveloped resources at present known in the world."94 In a speech to the prime ministers of the Dominions on August 13, 1918, Lord Arthur Balfour, the British foreign secretary, suggested that: "Mosul's oil reserves were so vast that it was probably the most important oilfield in the world." 95 The securing and annexing of Mosul became Britain's foremost objective during its campaign in the Middle East. In October 1918, a week after the armistice agreement between Turkey and the Allies had been signed, Britain seized control of Mosul. ${ }^{96}$ In doing so, the British hoped to eliminate any threat that the Germans and French posed to Britain's control of the vast oil fields in Baghdad, Basra, and in the Mosul area.

The second, and more important part of MacCallum's wartime analysis, was her treatment of Britain's diplomatic efforts to secure and consolidate its postwar preeminence in the Middle East. Her analysis examined three wartime agreements - the McMahon-Husayn-Agreement of 1915, the Sykes-Picot Agreement of 1916, and the Balfour Declaration of 1917. Negotiated over a three-year period, these accords represented three very different visions of a possible future British Middle East policy, and the British Empire's determination to control the area. They are vital to our understanding, because they form a basis of so much of what was to come after.

\footnotetext{
${ }^{94}$ Barr, A Line in the Sand, p. 66. For the French perspective on Mosul, see: Edward Peter Fitzgerald, "France's Middle Eastern Ambitions, the Sykes-Picot Negotiations, and the Oil Fields of Mosul, 19151918," The Journal of Modern History, Vol. 66, No. 4 (December, 1994), pp. 700-702.

95 Rothwell, "Mesopotamia in British War Aims, 1914-1918,” p. 290.

96 Ibid. Under the terms of the armistice, the Ottomans surrendered their remaining garrisons in Hejaz, Yemen, Syria, Mesopotamia, Tripolitania, and Cyrenaica; the Allies were to occupy the Straits of the Dardanelles and the Bosporus, Batum (now in southwest Georgia), and the Taurus tunnel system; and the Allies won the right to occupy, "in case of disorder," the six Armenian provinces.
} 
The first and most ill-conceived of the three agreements was the McMahonHusayn agreement of 1915. On the orders of Lord Kitchener, the British secretary of state for war, Ronald Storrs, the oriental secretary to the British Agency in Cairo, sent an intermediary to inquire whether Sayyid Husayn bin Ali, the Sharif and Emir of Mecca, would assist Great Britain in their conflict with Turkey. In exchange, Sir Henry McMahon, the British high commissioner in Egypt, guaranteed the Arabs "independence, rights, and privileges of the Sharifate." ${ }^{\prime 97}$ Initially, the offer was rejected. The proposal only offered the Sharif of Mecca protection of Mecca and Medina from the Ottoman Turks. ${ }^{98}$ The Sharif and his son Abdullah wanted much more from the British. Thus, they opened negotiations with the British through a series of intermediaries, ${ }^{99}$ and the exchange of ten letters. Over time Britain's limited pledge evolved into a formal recognition of Arab independence, if the Arabs could mount a successful revolt against the Turks. ${ }^{100}$

But what did Arab independence mean? The British recognized the "principle" of Arab independence, but no more. It was a euphemism for the suppression of Turkish rule. It also meant the liberation of the Moslem holy places in the Middle East, which had been previously under Turkish control. ${ }^{101}$ David G. Hogarth, formerly the director of the Arab

\footnotetext{
97 Aaron Klieman, “Britain's War Aims in the Middle East, 1915," Journal of Contemporary History, Vol. 3, No. 3, The Middle East (July, 1968), p. 243. For a detailed explanation of the negotiations, see: Ronald Storrs, The Memoirs of Sir Ronald Storrs (New York: G. P. Putnam’s Sons, 1937).

98 Ibid.

${ }^{99}$ For the Arabs, Prince Abdullah, and for the British, Richard Storrs, served as intermediaries.

${ }^{100}$ Elie Kedourie, In the Anglo-Arab Labyrinth: The McMahon-Husayn Correspondence and Its Interpretations, 1914-1939 (Cambridge: Cambridge University Press, 1976), p. 4.

${ }^{101}$ Isaiah Friedman, "The McMahon-Hussein Correspondence and the Question of Palestine," Journal of Contemporary History, Vol. 5, No. 2 (1970), pp. 84-85.
} 
Bureau in Cairo, confirmed this view. ${ }^{102}$ In briefing British Foreign Office officials, Hogarth declared that, apart from the holy places, the negotiations had conveyed to Husayn the impression that Britain was not committed to the establishment of an independent Arab state or a confederation of Arab states. ${ }^{103}$ The British were determined to fill the vacuum left by the dismemberment of Turkey, not to turn over the whole region to the Arabs. The Arabs, in contrast, viewed the pledge of independence to mean liberation from their Turkish adversaries. To Husayn and the Hashemites, this was the first step in acquiring Arab independence. Knowing that Arabs could not stand on their own against the Turks during the war, Husayn recognized that an independent Arab state would need, for at least the time being, to be carefully managed and protected by the British Empire.

On the practical question of what territory any new Arab state would include, Husayn asked the British high commissioner for the whole Arabian peninsula, except Aden, and all of Mesopotamia, Palestine, Transjordan, and Syria, running up to the borders of Persia on the east and slightly into the Turkish state on the north. ${ }^{104}$ Foreseeing difficulties in accepting such definite commitments, McMahon suggested that Husayn "wait and see what the situation would be at the close of hostilities." Husayn, however, would not be put off. He stated that these were not his demands but the aspirations of the Arab peoples. Thus, on October 24, 1915, McMahon relented and agreed to Husayn's

102 David G. Hogarth, "Wahabism and British Interests," Journal of the British Institute of International Affairs, Vol. 4, No. 2 (March, 1925), p. 72.

103 Ibid.

104 J. De V. Loder, The Truth about Mesopotamia, Palestine \& Syria (London: George Allen \& Unwin Ltd., 1923), pp. 19-20. 
request, with the exception of the "two districts of Mersina and Alexandretta and portions of Syria lying to the west of the districts of Damascus, Homs, Hama and Aleppo." 105 McMahon stated that:

As for those regions lying within those frontiers wherein Great Britain is free to act without detriment to the interests of her ally, France, I am empowered in the name of the Government of Great Britain to give the following assurances and make the following reply to your letter: "Subject to the above modifications, Great Britain is prepared to recognize and support the independence of the Arabs in all regions with the limits demanded by the Sharif of Mecca."106

With McMahon's reply, the negotiations came to a close and both sides regarded

the bargain as concluded. The Arabs regarded the agreement as their Magna Carta. ${ }^{107}$ Yet how much of the Arab territory was included became a subject of controversy in the years that followed the war, and the controversy was particularly acute in regard to that part of Syria that became the mandated territory of Palestine. Was Palestine included in the agreement? McMahon's letter of October 24th made no clear mention of Palestine. It was the British contention that Palestine was excluded by implication when McMahon notified the Sharif that " portions of Syria lying to the west of the districts of Damascus, Homs, Hama and Aleppo' were to be excluded from the area of Arab independence."108 However, the Arabs argued that, since McMahon did not explicitly include Palestine as

\footnotetext{
105 Royal Institution of International Affairs, Great Britain and Palestine, 1915-1945 (Westport, Conn.: Hyperion Press Inc., 1976), p. 5.

106 Ibid.

107 Ibid.

${ }^{108}$ George Antonius, The Arab Awakening (New York: G. P. Putnam's Sons, 1946), p. 177.
} 
an exception, as he had Mersina and Alexandretta, it followed that it was ipso facto included in the territories granted to the Arabs. ${ }^{109}$

The Palestine question became the central narrative in the Arab grievances that were laid at the feet of the Western powers. And the terms of the McMahon-Husayn correspondence became known all over the Arab World as an act of British treachery. The Arabs got none of what they were promised in return for their help in the war. Arab apologists have long argued that the McMahon-Husayn agreement predated the 1916 Sykes-Picot agreement, the Balfour Declaration of 1917, and the San Remo declaration of $1920,{ }^{110}$ and therefore superseded all their claims. Elie Kedourie, the noted British historian of Anglo-Arab affairs, argued that:

The genesis, and the subsequent official interpretations of the McMahon [Husayn] correspondence, are essential to the understanding of a great deal of Middle Eastern diplomatic history during and after the first world war, as well as the Palestine dispute in the 1920s and 1930s. ${ }^{111}$

Before the ink was dry on McMahon's October 24th pledge to Husayn, the British government began secret negotiations with the French government for the postwar division of the Ottoman Empire. Following McMahon's earlier letter to Husayn, Lord Grey, the British foreign secretary, fearing that rumours of the McMahon-Husayn discussions would reach French officials, informed Paul Cambon, the French ambassador to Great Britain, of the British contact with the Arabs. ${ }^{112}$ Grey suggested that their

\footnotetext{
109 Ibid.

${ }^{110}$ Elie Kedourie, In the Anglo-Arab Labyrinth: The McMahon-Husayn Correspondence and its Interpretations, 1914-1939 (London: Frank Cass, 2000), p. 3.

111 Ibid, p. xi.

112 Robert McNamara, The Hashemites: The Dream of Arabia (London: Haus Publishing Ltd., 2009), p. 52.
} 
governments should begin to sort out Anglo-French thinking on Asiatic Turkey. In particular, Grey proposed that France appoint a special representative to discuss the question in detail with a representative of Britain. ${ }^{113}$ This was a bold initiative, considering the sound beating the British had received at the hands of the Turkish army at Gallipoli.

The French appointed François Georges Picot, a practiced diplomat and a tough bargainer with expert knowledge of the Middle East in general and the Levant in particular. Initially, Sir Arthur Nicholson, the British permanent under-secretary of the foreign office, represented Britain in the negotiations. Distrustful of British relations with the Arabs, and unsympathetic to the idea of an Arab kingdom, a determined Picot demanded "nothing less than the whole of Syria from Taurus to the Egyptian border." 114 Picot and the Quay d'Orsai saw the creation of an independent Arab state as a meaningless gesture on Britain's part. It would be a house divided by clan and religious differences. An Arab state or federation would have no real power, Picot told Nicholson. "To promise the Arabs a large state is to throw dust in their eyes ... . Such a state will never materialise. You cannot transform a myriad of tribes into a viable whole." 115 While the British doubted the capacity of the Arabs to govern themselves, they believed in time, mentored by the British, they might be able to manage their own affairs. To Nicholson and the Foreign Office, Picot's expansive demands were as breathtaking as they were

\footnotetext{
113 Jonathan Schneer, The Balfour Declaration: The Origins of the Arab-Israeli Conflict (Toronto: Random House of Canada, 2010), p. 76.

114 Jukka Nevakivi, Britain, France and the Arab Middle East, 1914-20 (London: The Athlone Press, 1969), p. 30.

${ }^{115}$ Barr, A Line in the Sand, p.28.
} 
impractical, considering France's meagre military presence in the Middle East in 1915, and the Arabs' open hostility to the French. ${ }^{116}$ Consequently, the negotiations failed to find common ground and broke off.

The deadlock compelled the British government to change the negotiator and their tactics. Encouraged by Lord Kitchener, Sir Mark Sykes, a diplomatic expert, was appointed Britain's principal negotiator. While Picot was urbane and reserved, Sykes bubbled with enthusiasm. He was easy to like. Yet he lacked practical experience in the negotiations of the kind with which he was now entrusted. ${ }^{117}$ In November 1915, Sykes and Picot sat down to partition the Ottoman Empire, and more particularly, the Arab lands. By May 31, 1916, they had finalized an agreement. After scrutinizing the details of the accord, the British and French governments endorsed the secret plan. The Sykes-Picot agreement divided Arab lands into five zones. Two zones would be directly administered by the British and French; two zones would be "spheres of influence"118; and one zone, Jerusalem, would be internationally administered. More precisely, it was to be administered by an international condominium of Great Powers. The zone of direct British administration consisted of Mesopotamia, from Basra to the north of Baghdad. It also included a small enclave on the Syrian coast, which incorporated the ports of Haifa and Acres in Palestine. France's zone of direct administration included Cilicia, a large part of central Anatolia, Lebanon, and a broad strip of territory extending along the

\footnotetext{
${ }^{116}$ McNamara, The Hashemites, p. 53.

${ }^{117}$ Nevakivi, Britain, France and the Arab Middle East, p. 32.

${ }^{118}$ J. De V. Loder, The Truth about Mesopotamia, p. 25. The spheres were areas where only one nationality of advisers and foreign officials were permitted.
} 
Syrian coast, which was comprised of the Vilayets (provinces) of Aleppo, Beirut, and Damascus, and the oil-rich territory of Mosul-Kirkuk. Britain's sphere of influence included the territory between Palestine and Mesopotamia, which extended from Tikrit to the southern edge of Kurdistan. The French sphere of influence, included the cities of Damascus, Aleppo and Mosul. ${ }^{119}$ This was the same territory promised the Arabs under the terms of the McMahon-Husayn discussions.

The Sykes-Picot agreement of 1916 was a "striking example of traditional [European] diplomacy within the Middle East context. It amounted to a calculated division in advance of territorial spoils and war." ${ }^{120}$ In 1938, twenty-two years after the publication of the Anglo-French accord, former British Prime Minister Lloyd George wrote: "why the British did not notify [the Arabs] of this important agreement is incomprehensible. They were directly concerned for it disposed of their future government and wide areas of great renown. When it became known to the Arab leaders, it naturally gave offense to them."121 Perhaps the greatest Arab grievance towards the Anglo-French pact was not the betrayal of the Arab territorial ambitions as much as the assumption on the part of the two European powers that those territories that the Arabs were to receive would be nothing more than puppet regimes. Shortly after the Russian Bolsheviks took power in 1917, they discovered and published the Sykes-Picot agreement. The Bolsheviks publicly revealed that the Western powers intended to redraw

\footnotetext{
119 Ibid.

120 Aaron Klieman, Foundations of British Policy in the Arab World: The Cairo Conference of 1921 (Baltimore: John Hopkins Press, 1970), p. 13.

${ }^{121}$ David Lloyd George, The Truth About Peace Treaties (London: Victor Golancz Ltd., 1938), p. 38.
} 
the map of the world in their own interests once they had won the war. This became a warning to Arab nationalists who had believed the British would liberate them from the yoke of Turkish oppression.

The last secret agreement, which was largely unknown to the Arabs, was the British government's decision to take upon itself a further obligation in the Middle East. This time the obligation was extended to the Jewish people. Since the early fall of 1915 , British Zionists had sought British endorsement of their claim to Palestine as the historical and spiritual homeland of the Jewish people. In return for an official endorsement, the Zionists were prepared to assist the Allies in their struggle with the Central Powers. The Asquith government had been unwilling to accept the Jewish offer. $^{122}$ It was not until Lloyd George had succeeded Asquith as prime minister that British authorities seriously considered the Jewish proposal. In the late summer and early fall of 1917, after several sessions devoted to the discussion of the implications and wording of a declaration regarding Palestine, the British cabinet authorized Lord Balfour, the British secretary of state for foreign affairs, to issue a statement in the form of a letter to Lord Rothschild on November 2, 1917, which stated:

His Majesty's Government view with favour the establishment in Palestine of a national home for the Jewish people, and will use their best endeavours to facilitate the achievement of this object, it being clearly understood that nothing shall be done which may prejudice the civil and religious rights of existing non-Jewish communities in Palestine, or the rights and political status enjoyed by Jews in any other country. ${ }^{123}$

\footnotetext{
122 Schneer, The Balfour Declaration, p. 43.

123 Sykes, Crossroads to Israel, p. 15. For a detailed analysis of the Balfour Declaration, see: Leonard Stein, The Balfour Declaration (New York: Simon \& Schuster, 1961). Lord Rothschild was an active
} 
Sykes-Picot and the Balfour Declaration had shone a naked light upon British strategic thinking regarding the Middle East during the First World War; the agreement not only revealed a Great Power's determination to reinvigorate its empire through territorial expansion, but more importantly, it revealed that it had no intention to assist the Arabs in achieving independence.

\section{MacCallum and the Wartime Agreements}

MacCallum condemned all of these bargains. For her, the agreements were motivated by imperialist designs. The British were prepared to seize, occupy, and transform the remnants of the Ottoman Empire into lands that would service the needs of the British Empire commercially, politically, and militarily. A foreign occupier, once again, would dash hopes of Arab independence. The consequences were abundantly clear to MacCallum. The three agreements would forever be a blight on the Middle East by constraining Arab aspirations and rights; ensuring a reinvigorated anti-Western Arab nationalist movement; triggering increased Anglo-French tensions in the region; necessitating future Great Power condominiums in the region; ${ }^{124}$ and forcing the establishment of a Jewish State, which would set fire to previously peaceful Arab-Jewish relations and initiate protracted instability in the region. ${ }^{125}$

supporter of Zionism in Britain. In association with Chaim Weizmann, president of the Zionist Organization, he worked to formulate the draft Balfour Declaration for a Jewish homeland in Palestine.

124 See Quincy Wright, Mandates Under the League of Nations (New York: Greenwood Press, 1930); Freda White, Mandates (London: Jonathan Cape Ltd., 1926); H. Duncan Hall, Mandates, Dependencies, and Trusteeship (London: Stevens \& Sons Limited, 1948); United Nations Organization, "International Trusteeship System and the Trusteeship Council," Background Paper, No. 57, March 17, 1950 (Lake Success, N.Y.: U. N. Department of Public Information Section).

125 Elie Kedourie, In the Anglo-Arab Labyrinth, p. 4; C. Ernest Dawn, From Ottomanism to Arabism: Essays on the Origins of Arab Nationalism (Chicago: University of Illinois Press, 1973). 
Like other scholars and commentators writing on wartime agreements and the Middle East, MacCallum confronted a subject matter steeped in controversy, secrecy, and speculation. The contemporary histories were rarely based on original research; ${ }^{126}$ historians and writers were almost always denied access to government records regarding these agreements. This was particularly true in the case in the Husayn-McMahon correspondence. The British government placed a public access ban on the correspondence, cabinet records, and all pertinent memoranda until $1964 .{ }^{127}$

For MacCallum, the McMahon-Husayn Agreement of 1916 unquestionably formed the foundation of Britain's ill-conceived and misguided postwar Middle East policy, and accounted for much of the animosity and scorn heaped on Britain in the postwar Arab World. She was convinced that the agreement was born of British ignorance and imperialist aspirations. In MacCallum's opinion, Britain's apparent commitment to the cause of Arab independence was never meant permanently to bind the British to Arab aspirations. She insisted that the raison d'être for the McMahon-Husayn agreement was as a calculated response to a series of difficult military situations that

${ }^{126}$ David Fromkin, A Peace to End All Peace: The Fall of the Ottoman Empire and the Creation of the Modern Middle East (New York: Henry Holt and Company, 2001), p. 86.

${ }^{127}$ Isaiah Friedman, "The McMahon-Hussein Correspondence and the Question of Palestine," in Journal of Contemporary History, Vol. 5, No. 2 (1970), p. 83. British officials justified the 48-year censorship of the records on the grounds that the "publication would be "detrimental to the public interest." It was believed that the correspondence would expose Britain's efforts to convince the Sharif of Mecca "to rebel against the Sultan-Caliph in Constantinople and seek the Caliphate for himself with British assistance." It was feared that disclosure would "precipitate a storm of indignation in the Moslem world, particularly in India." While the complete text of the correspondence was not revealed for almost fifty years, numerous interwar summaries did reveal some of the details of the negotiations: Seymour F. Cocks, The Secret Treaties and Understandings (London: Union of Democratic Control, 1918); J. De Loder, The Truth about Mesopotamia, Palestine \& Syria (London: George Allen \& Unwin Ltd., 1923); Amir Faisal, "Notes on the Arab Question," in Fortnightly Review, Vol. 136 (1929), pp. 735-736; Sir George Fletcher MacMunn and Cyril Falls, Military Operations, Egypt \& Palestine From the Outbreak of the War with Germany to June 1917, Vol. 1 (London: Government of Great Britain, 1930). 
Britain found in Mesopotamia, Syria, and Palestine, ${ }^{128}$ and was done with an eye to future strategic considerations. This judgement was consistently woven throughout MacCallum's interwar studies. In her 1927 study, The Nationalist Crusade, she argued that the Anglo-Arab agreement was never intended to be anything more than "a temporary expedient for obtaining convenient assistance from the Arabs at a time of special need." ${ }^{129}$ In 1930, she further reasoned that, in order to secure the aid of the Arabs in the war with Turkey, "Great Britain found it necessary to promise [Husayn] the Sharif of Mecca that Great Britain would recognize and support the independence of the Arabs. . .."130 Scholars agreed with MacCallum's hypothesis. Middle East commentator Elizabeth Monroe, more than a decade after MacCallum's writings appeared, echoed her sentiments:

Promises given under stress sometimes prove awkward when the stress is past, but Great Britain, in thus committing herself to the Jew and Arabs, had no fears for the future. The undertaking added to her immediate chances of victory, but, as far as she could see, they also added to her ultimate security. ${ }^{131}$

${ }^{128}$ MacCallum, "The Palestine Conflict," p. 275. The Foreign Office needed to counter the Turkish SultanCaliph's call on all Moslems for a Jihad against the three enemies of Islam - Britain, France, and Russia. The British War Ministry was deeply concerned about the mental state of its Moslem Indian forces. Would they obey the Caliph and turn on their British comrades in arms? Would they refuse to kill a fellow Moslem? This concern was further complicated by the large proportion of Moslem Arab forces in the Turkish army, which had engaged the British in Egypt, Mesopotamia, and Palestine. Finally, with the Allies' failure at Gallipoli, and the imminent threat of a Turkish capture of the Suez Canal and the head of the Persian Gulf, where lay the valuable oil fields of the Anglo-Persian Oil Company (APOC), the British sought the means of getting the Arabs to change sides, or at the very least, getting them out of the war. In A Peace to End All Peace, p. 104. David Fromkin supported MacCallum's views when he revealed the machinations behind the British deliberations surrounding the pledges. Fromkin asserted that Kitchener and his associates in Cairo were preparing for the next war with Russia. He suggested that the Arabs never saw the broader scope of Kitchener's planning.

${ }^{129}$ MacCallum, The Nationalist Crusade in Syria, p. 26

${ }^{130}$ MacCallum, "Iraq and the British Treaties," p. 228.

${ }^{131}$ Elizabeth Monroe, The Mediterranean in Politics (London: Oxford University Press, 1938), p. 55. 
MacCallum saw that Britain's wartime diplomacy reflected a much larger strategic canvas, with the Arabs as little more than the landscape. She correctly understood that Britain's negotiations were not exclusively committed to Husayn. She appreciated that, in order to better position the Empire and defend its imperial interests, Britain had opened up a series of negotiations aimed at solidifying its postwar Middle East arrangements with other states. Russia and France were determined to dismember the Ottoman Empire and annex large and strategically important portions of the Turk's territory. ${ }^{132}$ Principally concerning to the British was Russia's demand for Constantinople and control of the Dardanelles and the Bosporus Straits. France was no less demanding. The French wanted to annex Syria together with the region of the Gulf of Alexandretta and Cilicia. They hoped that these annexations would help them achieve a pre-eminent role in the Levant.

The British Foreign Office saw these demands as fundamentally altering Europe's balance of power. More importantly, they believed that the territory the Russians and French would receive posed an outright threat to British strategic interests in the region; that is, to Egypt, the Suez Canal, and ultimately British India. The threat of these annexations compelled the British to formulate their own requirements. Believing that the Ottoman Empire's dismemberment was inevitable, the Foreign and India Offices were divided on the question of annexing more Turkish territory. The India Office wanted Turkey to remain as strong as possible in order to withstand Russian encroachment. In contrast, the Foreign Office believed that Turkey should be sacrificed if Britain was to

\footnotetext{
${ }^{132}$ Klieman, "Foundations of British Policy in the Arab World," p. 237.
} 
meet the challenges posed by Russia and France. The Arabs were a secondary consideration in British discussions.

It was the Sykes-Picot Agreement of May 1916 that MacCallum believed was the zenith of Britain's imperial ambitions because it subverted and discredited Whitehall's avowed commitment to Arab independence. Sykes-Picot was a blatant product of Great Power politics and imperialist greed and a startling piece of double-dealing. At the same time that the British were negotiating with Husayn, they had secretly engaged the French in formal talks about partitioning and annexing Arab territories after the war. ${ }^{133}$ If McMahon had informed Husayn of the Anglo-French negotiations, it is very likely that the Sharif would have renounced the Anglo-Arab alliance and sided with the Central Powers. For MacCallum, this was undoubtedly a reason the British kept the Sykes-Picot negotiations secret and Husayn in the dark about Britain's true intentions.

MacCallum recognized the threat of a reinvigorated Arab nationalism and worsened Anglo-Arab relations. This was a great concern for many British officials in the India Office, the Arab Bureau, and the Foreign Office, who were worried about the face of postwar Arab power. MacCallum's postwar analyses acknowledged many of these concerns. In 1930, she spoke of a rising Arab discontent and anti-Western sentiment. "Arab nationalism," she warned, was "becoming an increasingly incalculable element in the Asiatic scene."

It has largely displaced religious and sectarian strife as a major preoccupation of the Arab mind, and it would undoubtedly interfere with

133 The Sharif was also simultaneously negotiating with the Ottoman's Grand Vizier for increased autonomy for the Hejaz. 
European plans for administration of the land-bridge between the Mediterranean and the Persian Gulf. ${ }^{134}$

A widespread Arab nationalist revival, posited MacCallum, was something the European powers could ill afford to ignore. Arab nationalism was gaining momentum and it would be a force to be reckoned with. ${ }^{135}$ In marrying the rationales for the Sykes-Picot and the McMahon-Husayn agreements, MacCallum suggested that Britain's Middle East policy was both pragmatic and strategic. Its pragmatism was dictated by the considerations of winning the military campaign, and derived from the imperial considerations of safeguarding British India and adjusting the British Empire constantly to advantage. ${ }^{136}$ Britain's Anglo-French entente always outweighed any consideration of commitments made to the Arabs.

A constant thread woven through virtually all of MacCallum's studies was the First World War British strategy that shaped their Palestine policy in the postwar years. On November 2, 1917, MacCallum explained, British policy once again changed with the announcement of the Balfour Declaration. ${ }^{137}$ MacCallum pointed out that the Declaration raised serious questions about Palestine's future and the direction of Britain's postwar Middle East policy. Did the announcement presage a new course in Britain's postwar plans? Was it a short-term policy like the McMahon-Husayn agreement, which simply

\footnotetext{
${ }^{134}$ MacCallum, “The Arab Nationalist Movement,” p. 50.

135 Elizabeth MacCallum, "The League of Nations and the Arab World," [n.d.], MacCallum Papers (Unpublished essay), p. 1.

${ }^{136}$ For further information on its reorganization, see: Frank Chambers, The War Behind the War (New York: Harcourt, Brace \& Co., 1939); Paul Guinn, British Strategy and Politics 1914-1918 (Clarendon Press: Oxford University Press. 1969).

137 Elizabeth MacCallum, "Background of Unrest in Ancient Palestine," New York Times (September 1, 1929), p. 4. Also see: MacCallum, "Iraq and the British Treaties," pp. 228-229.
} 
reflected a worsening military situation? Or did it provide a clue to a future Middle East policy?

MacCallum provided two possible answers. First, she believed that "the British sought by this declaration to win wider and more active support for the Allied cause in Jewish circles." 138 Second, the Balfour Declaration had made it clear that Britain was not prepared to turn the Middle East over to the Arabs. A pro-British Jewish National Home furthered Britain's strategic interests. In April 1917, within weeks of becoming the prime minister, David Lloyd George commissioned the Curzon Committee to study the postwar settlement. The Committee report concluded that Palestine was a territory of the utmost importance to the future security and the well-being of the British Empire. ${ }^{139}$ General Jan Smuts, the defence minister of South Africa, told the Curzon Committee that:

Any other power in Palestine would be a very "serious menace to our communications." British control of Palestine and Mesopotamia, which would no doubt eventually be connected by railway, would cover the whole approach to the East, protecting both Egypt and the Persian Gulf. From the military and political point of view, Smuts said that he regarded a satisfactory settlement of the Palestine question as the most important of all of the questions under discussion "except perhaps that of East Africa." $" 140$

In December 1918, with the Balfour Declaration in hand, Lloyd George made it clear to the French prime minister that Britain was going to assume control of Palestine. Georges Clemenceau felt he had little choice but to accede to the British demand. ${ }^{141}$

\footnotetext{
${ }^{138}$ Ibid.

139 Schneer. 169.

${ }^{140}$ Ibid, p. 135.

141 Ibid, p. 277.
} 
For MacCallum, the Balfour Declaration and its implicit repudiation of the McMahon-Husayn agreement unleashed unpredictable Arab nationalistic forces in the region. It destroyed the good will and support that the British had built up in the region during the war years. The apprehension about a possible Arab backlash accounted for the Anglo-French Declaration of 1918, in which Britain and France attempted to reassure the Arabs that they were still committed to Arab liberation, independence, and self-rule under, of course, imperial tutelage. ${ }^{142}$ Publicized throughout Palestine, Syria, and Mesopotamia, the Anglo-French pronouncement was meant to reaffirm the pledges made to the Arabs. ${ }^{143}$ The contradictions were palpable.

MacCallum's analysis constantly returned to the resurgence of Arab political nationalism. ${ }^{144}$ The Arabs' deep suspicions about the European presence in the Middle East had been confirmed. ${ }^{145}$ The war had provided the Europeans a golden opportunity to carve up the Ottoman Empire. This was evident in Britain's decision to annex and establish Protectorates over Egypt and Cyprus. ${ }^{146}$ By war's end, the British had more than a million soldiers occupying Syria, Mesopotamia, Palestine, and Transjordan. It soon

${ }^{142}$ MacCallum, "The Palestine Conflict," p. 276. MacCallum asserted that just before the Armistice of 1918, Britain and France in the final push needed Arab support; therefore, they provided another carrot for the Arabs, and tried to allay any fear that the British were going to repudiate their pledges.

${ }^{143}$ Ibid, p. 277.

${ }^{144}$ MacCallum, "The Arab Nationalist Movement," p. 52.

${ }^{145}$ Ibid.

146 G. R. Berridge and Alan James, A Dictionary of Diplomacy, p. 196. A "Protectorate" as a protected state, or a state over which a state or groups of states exercise authority. "To all intents and purpose, therefore, British protectorates were in the position of "colonies."' 
became apparent to the Arabs, MacCallum asserted, that Britain had no immediate plans to leave the region or relinquish control over it. ${ }^{147}$

\section{Mandates, Protectorates, and Alliance Treaties}

In MacCallum's writings about the postwar order, another persistent theme was Great Power domination of the Middle East. Her central thesis continued to be that international rivalry, specifically, the Anglo-French rivalry, dictated the nature and terms of the international postwar framework. ${ }^{148}$ The imperial powers, said MacCallum, employed various mechanisms — old and new — to occupy and control the Middle East. As historian William Roger Louis has pointed out, none of the victorious countries were prepared to return conquered territories to the Germans or the Turks. Too much blood and treasure would have needlessly been spent.

The alternative to annexation was to place the territories under international control. ${ }^{149}$ To do this, the League of Nations confirmed the Mandates awarded by the Supreme Allied Council at the April 24, 1920 San Remo Conference, and created a Mandates System under Article 22 of the League's Covenant. Through the Mandates System, the League extended to the former territories and colonies of the Ottoman and German Empires a "promise of security for their well-being and development under the tutelage of advanced nations acting as mandatories on behalf of the League of

\footnotetext{
${ }^{147}$ Elizabeth MacCallum, "Egyptian Nationalism and British Interests," FPAIS Vol. 3, No. 11 (August 3, 1927), p. 156.

${ }^{148}$ MacCallum, "The Arab Nationalist Movement,” p. 53.

${ }^{149}$ Wm. Roger Louis, Great Britain \& Germany's Lost Colonies, 1914-1919 (Oxford: Clarendon House, 1967), p. 17.
} 
Nations. ${ }^{150}$ Since the Mandates differed according to the stage of the development of the people, the physical situation of the territory, its economic conditions, and other similar circumstances, three categories of Mandates were established. Class "A" Mandates included the former provinces of the Ottoman Empire - Syria, Lebanon, Palestine, Transjordan, and Iraq. "Class "B" Mandates, former African colonies of the German Empire, included: Cameroon, Togoland, the Tanganyika territory, and Ruanda-Urandi. Class "C" Mandates referred to Far East territories, which included the islands of Nauru, New Guinea, and Western Samoa.

Since the Mandates were established outside of the League of Nations' jurisdiction, the authority for the Mandate System rested firmly with the Mandatory powers, which controlled and administered the territory. Their only obligation to the League was to render annual reports to the League Council on the progress of the Mandatory territory. The League, with limited authority over the Mandates, created the Permanent Mandates Commission (PMC) to monitor the annual reports. It advised the Council on all matters relating to Mandates. ${ }^{151}$

While MacCallum appreciated the merits of the Mandates System, she ultimately saw it as a contrivance designed to advance the two principal aims of European imperialist powers. Primarily, it was meant to perpetuate their age-old policies of annexation through the right of conquest. She cited the San Remo Conference of April 24, 1920 as a case in point. Attended by the Allied Powers only, the Conference granted

150 Elizabeth MacCallum, “The French Mandate in Syria," Foreign Policy Association Editorial Information Service (FPAEIS), Series 1925-1926, No. 5 (December 5, 1925), p. 1.

${ }^{151}$ Freda White, Mandates (London: Jonathan Cape Ltd., 1926), p. 16. 
the French the Mandatory authority for Lebanon and Syria, while Britain received the authority for Mesopotamia, Palestine, and Transjordan. This was all done without ever hearing from the inhabitants of the territories, the defeated nations, or the newly created League. ${ }^{152}$ In the first of many essays that MacCallum wrote concerning the legitimacy of the Mandates System, she argued that the:

choice of Mandatory Power was in the case of each Class A Mandate based on previous secret agreements between France and Great Britain rather than on the wishes of the inhabitants themselves. Terms of the Mandates were drafted not by the League of Nations but by France and Britain acting in collaboration. .. . The role of the League was limited largely to confirming the Mandates awarded by the Allies to themselves on their own terms. And once having confirmed the Mandates the League has had no power to revoke them. ${ }^{153}$

MacCallum posited that, in principle, an aim of the Mandates was to nullify or reduce the dangers inherent in international rivalries. In "The International Problem of Tangier," she contended that, prior to the establishment of the Mandate System, the record of international administration had been one of notorious inefficiency. ${ }^{154}$ European powers had historically stumbled over one another in their international administration of contested regions. This resulted in jealousy and increased international frictions, which prevented any beneficial process or outcome. ${ }^{155}$ The Mandate System hoped to correct these problems by making a single advanced nation exclusively responsible for the dependent territory's mentorship and administration. It was believed by the Great Powers that, by establishing clear lines of authority, a Mandatory Power could exercise freedom

\footnotetext{
${ }^{152}$ MacCallum, "Class A Mandates,” p. 6.

${ }^{153}$ Ibid, 2.

${ }^{154}$ MacCallum, “The International Problem of Tangier,” p. 170.

155 Ibid, p. 174.
} 
of action without interference from possible rivals or from the League's PMC. ${ }^{156}$ That might be good for the Great Powers, conceded MacCallum, but not for those people on the receiving end of the arrangement.

MacCallum was convinced that neutralizing international rivalries was central to the rationale for the Class "A" Mandates. Stability among European countries was considered far more important than the growth and development of the Arab peoples. ${ }^{157}$ Thus, if a region, state, or territory was not contested by the Great Powers, a Mandate was unnecessary. This view was confirmed by the Allied Powers' decision to exclude the southern Arab territories of the Hejaz, Nejd, Sa'udi Kingdom, and Yemen of the Arabian Peninsula from Class "A" Mandates. Yet MacCallum pointed out that the Arab people of the Peninsula, as compared with the Arab peoples of Syria, Lebanon, and Mesopotamia, were far more backward. "Their standards of literacy and of general education were lower; they had fewer contacts with the outside world, their political outlook more primitive." ${ }^{158}$ Surely they needed the assistance of a Great Power. However, British authority was firmly rooted in the Persian Gulf and the Red Sea area; therefore, no European nation disputed or challenged that power. In the north it was a very different picture. International rivalry was much more prevalent. Turkey, Italy, Greece, France,

\footnotetext{
${ }_{156}$ Elizabeth MacCallum, "Class A Mandates," [n. d.] (Unpublished Essay), p 3. For a detailed explanation of the League of Nations' Permanent Mandates Commission, see: Elizabeth MacCallum, "Functions of the Permanent Mandates Commission," FPAIS, Vol. 3, No. 4 (April 27, 1927), pp. 45-60; Freda White, Mandates (London: Jonathan Cape Ltd., 1927); H. Duncan Hall, Mandates, Dependencies, and Trusteeship (London: Stevens \& Sons Limited, 1948); Quincy Wright, Mandates Under the League of Nations (New York: Greenwood Press, 1968).

${ }^{157}$ MacCallum, "The League and the Arab World," p. 7.

${ }^{158}$ MacCallum, "Class A Mandates," p. 5.
} 
Britain, and the Zionists were all attentive to the possibility of territorial expansion. ${ }^{159}$ And so Mandates were needed as a mechanism of controlling peoples inside and competition outside.

MacCallum therefore saw the imposition of the Mandates System and the partitioning of Arab lands as duplicitous and self-serving. She pressed the argument even further: if the alleged purpose of the Mandates was to enable the Arabs to stand alone under the strenuous conditions of life, why was it necessary to divide the Arab population of seven million into five distinct political entities? This arrangement certainly ran contrary to U. S. President Woodrow Wilson's wartime demand that every postwar settlement must be made for the benefit of the indigenous population concerned, and not as part of any mere adjustment of claims between rival states. ${ }^{160}$ The League had ostensibly been constituted to protect smaller entities from exploitation by larger powers. ${ }^{161}$ Moreover, MacCallum warned that the onerous nature of the Mandates did not guarantee peace and stability. In fact, it would probably have the opposite effect. It was fuel for an Arab rebellion, as demonstrated in Mesopotamia's Euphrates rebellion of 1920, Arab Syria's large-scale revolt in 1925, and the Palestine riots of $1929 .{ }^{162}$ From

${ }^{159}$ Ibid, p. 6.

${ }^{160}$ MacCallum, "The League and the Arab World,” p. 12.

${ }^{161}$ Hall, Mandates, Dependencies and Trusteeship, p. 33. Article 22 stipulated that there should be applied the principle that the well-being and development of such peoples form a sacred trust of civilisation and that securities for the performance of this trust should be embodied in this Covenant. The mandate was a "sacred trust".

${ }^{162}$ For a detailed examinations of the 1925 Arab Revolt Syria, of the Euphrates Rebellion of 1920, and Palestine Riots of 1929, see: Elizabeth MacCallum, The Nationalist Crusade; Michael Province, The Great Syrian Revolt and the Rise of Arab Nationalism (Austin, TX.: University of Texas Press, 2005); Phillip Willard Ireland, Iraq: A Study in Political Development, Chapter 14; George Antonius, The Arab Awakening, pp. 314-316; Elizabeth MacCallum, "The Palestine Conflict," FPAIS, Vol. 5, No. 16 
these uprisings, MacCallum concluded that the Mandates had fostered among the Arabs a deep resentment towards the Western powers, and indeed, towards the League of Nations, which Arabs believed had denied them their basic rights and arbitrarily imposed a form of de facto colonialism on them. Both the British and the League had denied Arabs free elections, self-governing institutions of their own making, control of their natural resources, and, ultimately, their own constitution. The Arabs viewed the Mandate System as yet another colonial tool to suppress them.

For MacCallum, the door had been opened to the specter of a violent, and a more militant, Arab nationalism. George Antonius' 1946 study, The Arab Awakening, reaffirmed MacCallum's conclusion. "The announcement of the San Remo decisions came as the crowning provocation; and, from that moment, the [Arab] feeling hardened into a determination to revolt." ${ }^{63}$ In "The League and the Arab World," MacCallum described in passionate terms the bitter resentment felt by Arabs towards the League of Nations as Britain's unblushing imperialist co-conspirator.

It [the League] had defrauded Mesopotamia and Syrian Arabs of the independence promised them by the Allies. It had foisted on Palestine a Jewish National Home under British military protection - by way of reparation to the Jews for injuries suffered not in the East but in Europe. . . . As for the Mandate System, which the League had sponsored, it was denounced as a fraudulent attempt to justify Western intervention in the Near East at a time when outright imperialism had ceased to be considered respectable. ${ }^{164}$

(October 16, 1929), pp. 273-294; Norman Bentwich, Palestine (London: Ernest Benn Limited, 1946); Howard M. Sachar, The Emergence of the Middle East: 1914-1924 (New York: Alfred A. Knopf, 1969).

163 Antonius, The Arab Awakening, p. 314.

${ }^{164}$ MacCallum, "The League and the Arab World,” p. 2. 
MacCallum saved her most severe criticism of the Mandates System for the British Mandate in Palestine. She saw its ultimate failure as a foregone conclusion. The British had tried to assure the Zionists that the British government was committed to realizing the Balfour Declaration by embedding it in the 1920 Palestine Mandate agreement. At the same time, they assured the Arabs that nothing would be done to prejudice the civil and religious rights of existing non-Jewish communities in Palestine. Yet the intent of the Mandate and its administration ensured the Zionists that normal political development would be arrested until they had become the dominant majority. Under Article 25 of the Mandate:

the Mandatory [Britain] shall be entitled, with the consent of the Council of the League of Nations, to postpone or withhold application of such provisions of this Mandate as the [the Mandatory Power] may consider inapplicable to the existing local conditions, and to make such provision for the administration of the territories as the [the Mandatory Power] may consider suitable to those conditions, provided that no action shall be taken which is inconsistent with the provisions of Articles 15, 16 and $18 .{ }^{165}$

Under this provision, the Mandatory Power could delay the development of selfgoverning institutions, such as an elected parliament, a constituent assembly, or local councils. Nothing in the Balfour Declaration or Mandate protected Arab "political rights." MacCallum believed that this ran contrary to the Covenant and its Article 22, which guaranteed the well-being and development of the indigenous population - it was not for the fulfillment of the desires of outsiders, no matter how urgent their need may be. ${ }^{166}$ The Arabs viewed the Mandate's provisions with contempt, reported MacCallum.

\footnotetext{
165 "British Mandate for Palestine," San Remo Conference, April 24, 1920.

${ }^{166}$ Elizabeth MacCallum, "The League and the Arab World,” p. 15.
} 
In her estimation, the Mandate would only create greater dysfunction and conflict. Under such a system, neither Arab nor Jew would allow the advancement of the other.

In a series of annual reports and feature articles for the FPA, MacCallum disclosed the deliberate efforts by the imperialist powers to control less advanced states. The most prominent instruments were the use of Protectorates and treaties of alliance. Both devices enforced imperial rule by controlling the client country's administrative apparatus, foreign policy, party system, government composition, and internal bureaucracies. MacCallum believed that Britain used these expedients to compel adherence to their strategic interests.

Through the use of the protectorate, MacCallum held that Britain thwarted Egyptian aspirations for independence and the greater democratization of its administration. She claimed that, when the Egyptian government attempted to reform its military institutions in the early postwar period, it was met by stiff opposition from the British. For example, when the Egyptian Parliament on May 23, 1922, issued a report calling for the elimination of the Sirdar, a long-standing rank assigned to the British Commander-in-Chief of the Egyptian Army,${ }^{167}$ the British dispatched three warships into Egyptian waters and delivered a note stating that any alteration of the military structure was a matter of mutual interest and thereby required mutual consent. ${ }^{168}$ The British would not tolerate any diminishment of its power or privilege unless it was in its strategic

\footnotetext{
${ }^{167}$ Elizabeth MacCallum, "Egyptian Nationalism and British Imperial Interests," FPAIS, Vol. 3, No. 11 (August 3, 1927), p. 154.

${ }^{168}$ Ibid, p. 155.
} 
interests to do so. ${ }^{169}$ In other words, any reform or modernization that they believed undermined the safety and security of British imperial communications, commercial interests, or defence would not be tolerated.

Even after the protectorate and martial law was ended, and Egypt's new status as a sovereign independent state was affirmed in a unilateral British declaration later in 1922. Egypt's protectorate status would not end until they had signed a Treaty of Alliance with Britain. Thus, if they wanted independence, Egyptians would have to accommodate themselves to the British. In the meantime, insisted MacCallum, the British continued to insist on their right to secure imperial communications, defend Egypt from foreign aggression or interference, protect British citizens, and maintain capitulations, ${ }^{170}$ while they coerced Egypt into signing another binding mutual security agreement. ${ }^{171}$

It would take an additional eight years of conflict with the British before Egypt promulgated a new constitution and an electoral system that was acceptable to both the British and Arab nationalists. ${ }^{172}$ Together the constitution and electoral laws enhanced King Fuad's prerogatives, strengthened the position of the Cabinet, and reduced the power of the Wafdist party, a political party committed to Egypt's complete independence and the withdrawal of British troops from Egypt. In exchange, the British

${ }^{169}$ Elizabeth MacCallum, "Political and Economic Trends in the Near East, 1927," FPAIS, Vol. 3, No. 26 (March 2, 1928), p. 27.

${ }^{170}$ Ibid, p. 159. Beginning in the 16th century, "capitulations" granted to European states the right to trade and travel freely, pay low custom duties, pay no domestic taxes, and to have civil and criminal cases for foreigners tried by their own consular courts.

${ }^{171}$ Elizabeth MacCallum, “The Near East in 1928,” FPAIS, Vol. 5, No. 4 (May 1, 1929), p. 76.

172 Elizabeth MacCallum, “Egypt: A Decade of Political Development,” FRAIS, Vol 6, No. 22 (January 7, 1931), p. 415. 
promised not to interfere in Egypt's domestic affairs. The British government, wrote MacCallum, had come to the conclusion that it "was time for Egypt to assume more complete responsibility in domestic affairs." Therefore, it announced its intention of adhering consistently to a policy of non-intervention. ${ }^{173}$ But Britain would still continue to have a military presence in Egypt that continued to protected its principal strategic asset, the Suez Canal, the gateway to India. ${ }^{174}$

MacCallum reasoned that a similar strategy was used in Iraq and Transjordan. Following the Euphrates rebellion of 1920 in Iraq, ${ }^{175}$ Britain effectively circumvented nationalists' resistance to Britain's continued presence in Iraq by successfully negotiating a bilateral agreement, which formalized the relationship between Iraq and Britain. MacCallum suggested that this agreement was a fundamentally different approach to the one taken in Palestine or Syria. It closely paralleled the arrangement made with Egypt. ${ }^{176}$ The British wanted to acquire control of the Mesopotamian oil fields, or, at the very least, the controlling interest in those fields. To achieve that goal, the British were prepared to end Iraq's Mandate and offer its leaders a treaty of equals. The British claimed that they desired a more equal relationship with Iraq and its citizens. The treaty gave the Iraqi administrative, domestic, and parliamentary reforms, culminating in the establishment of an elected Assembly. Britain's proposed reforms silenced overnight nationalist demands

\footnotetext{
${ }^{173}$ Ibid, p. 419.

${ }^{174}$ Kenneth Love, Suez: The Twice-Fought War (London: Longman, 1969), pp. 14-15.

175 Ibid, p. 230. Euphrates tribes protested against the Mandate and revolted. Subsequently, they gained support from Shi'ites. It took more than 80,000 British troops to end the rebellion. The Arab losses were high. The casualties amounted to 8,450 killed and wounded, while the British figures amounted to 876 killed and 228 wounded.

${ }^{176}$ MacCallum, "Iraq and British Treaties," p. 226.
} 
for a purely Arab government. Within ten months of the British proposal, the Anglo-Iraq treaty was signed on October 10, 1922. While Anglo-Iraq problems remained until 1930, when the Iraqis joined the League of Nations as an independent state, the British never deviated from their treaty-based pragmatic approach to securing British interests in Iraq.

The situation in Transjordan followed a somewhat similar course and trajectory as Iraq and Egypt, observed MacCallum. ${ }^{177}$ However, the Anglo-Tranjordian treaty differed in one significant way. The treaty acted as a de facto Mandate over Transjordan, but removed the reporting provisions defined in Article 22 of the League of Nations Covenant. In practical terms, the treaty more closely resembled a protectorate than a Mandate. The treaty, concluded in 1928, gave limited legislative and administrative powers to King Abdullah, son of Husayn, Sharif of Mecca, through a constitution. Britain still held the reins of power. Through a system of advisors to King Abdullah, Britain controlled foreign affairs, the defence of the country, and the economic and judicial system. ${ }^{178}$ Moreover, the treaty made no provision for Transjordan to become an independent state. For Arab nationalists, said MacCallum, Transjordan was further evidence of Britain's imperial ambitions in the region. ${ }^{179}$

\section{Tolstoy's Farm, Back to New York, and Home Again}

In the spring of 1931, fatigued and uneasy, MacCallum resigned from the Foreign Policy Association. Her hearing problems had worn her down. She had grown tense with

\footnotetext{
${ }^{177}$ MacCallum, "Political and Economic Trends in the Near East, 1927," p. 433.

${ }^{178}$ MacCallum, “The Near East in 1928," p. 70.

179 Ibid.
} 
efforts to listen to her colleagues and friends; everyday conversations were a trial. This tension, she later remarked, made her feel as if she were the wires in a grand piano, which were too tight, each sound resounding like a hammer. "The strain was intolerable; trying to converse was intolerable," she recollected. ${ }^{180}$ Feeling as if she was just sliding along the surface of life, she decided to follow "Tolstoy to the farm."181 Nineteenth-century Russian writer Leo Nikolayevich Tolstoy's teachings about the value of hard manual labour and simple living, in contrast to the artificiality of city living, inspired MacCallum's decision to leave New York. "We are far better off," she said, when "our minds are encircled by our hands." 182

Seeking solitude, MacCallum bought two acres of land one mile from Uxbridge, a township in south-central Ontario. For two years, she focused her efforts on gardening and writing. She gardened happily all summer and wrote steadily throughout the winter. With each new spring, she gratefully embraced the quiet friendliness of the community, in which she lived and renewed her life's energy. She was convinced that New York had slowly worked its way out of her system in the most pleasant way imaginable. Meanwhile, the hearing aid that she had been waiting for was finally available. On the farm, she quickly learned to be self-sufficient. When she began this experiment, she knew almost nothing of gardening. Yet, with the help of the local representative of the Ontario agricultural department and her friendly neighbours, she lived off the land. MacCallum

\footnotetext{
${ }^{180}$ Gordon Interview.

${ }^{181}$ Ettinger, "Elizabeth MacCallum,” p. 215. Also see: L. N. Tolstoy, Resurrection (New York: Thomas Y. Crowell, 1911).

182 Gordon Interview.
} 
thoroughly enjoyed the community environment as well. She joined the Hypatia Club, a women's literary club, in 1932-33, and shortly thereafter, was made the club's lifetime honorary president. ${ }^{183}$ "Mac," as her close friends called her at the Hypatia Club, maintained her close relationship with its members for more than 50 years. ${ }^{184}$

MacCallum was equally fruitful in her literary production. During her hiatus in Uxbridge, and owing to the Foreign Policy Association's need for a Middle East analyst, MacCallum continued to write for the Association's Foreign Policy Reports. ${ }^{185}$ However, no longer was she under the Association's editorial restraints. With a new sense of freedom, she wrote a dozen published and unpublished articles, and three books. ${ }^{186}$ The common thread throughout these new works was MacCallum's criticism of the conduct of European states and the League of Nations. She was particularly disparaging of the League's continued mismanagement of the Mandate System, and the increasing intrusiveness of European powers into the politics and economics of the Middle East. Historically compelling, her articles and commentaries pilloried the unjust treatment the Arabs had received at the hands of the Western Powers.

Particularly acerbic were her two unpublished essays: "The Class A Mandates" and "The League and the Arab World." In the first essay, MacCallum declared that the

\footnotetext{
${ }^{183}$ Ruth Wade, “Letter Concerning Dr. Elizabeth MacCallum,” MacCallum Papers, May 27, 2009.

184 Ibid.

185 Gordon Interview.

186 MacCallum, "The League and the Arab World," [n.d.], (Unpublished Essay], pp. 1-31; "The Class A Mandates," [n.d.], (Unpublished Essay), pp. 1-18; "Political Unrest in Transjordan," [n.d.], (Unpublished Essay), pp. 1-8; "Minorities in Syria and Iraq: A Review of League Policy under the Mandates System," [n.d.], (Unpublished Essay), pp. 1-13; "Great Britain and the Race Problem in Palestine," in Foreign Policy Reports, Vol. 10, No. 13 (August 29, 1934), pp. 158-168; “The Arab Nationalist Movement," in Foreign Policy Reports, Vol. 11, No. 5 (May 8, 1935), pp. 50-56.
} 
League of Nations' Mandate System, instead of acting as a possible force for democratizing the Middle East, achieved the opposite effect. She believed that the Mandate System was a by-product of the tensions existing in Europe and the Far East. ${ }^{187}$ Imperial and Colonial policies were gaining momentum at the end of the First World War. With the end of the Ottoman, Hapsburg, and German empires, there were great opportunities for the remaining imperial powers to acquire new territories. Britain's and France's first step was to partition the former Ottoman province of Syria into five smaller territories - Lebanon, Syria, Mesopotamia, Palestine, and Transjordan, thereby making it easier to control the Arab communities and "compel obedience." 188 As agreed under the modified Sykes-Picot agreement, Britain claimed for itself the Mandates for Palestine, Mesopotamia, and Transjordan, while France took Syria and Lebanon as their Mandates. In effect, the Great Powers had annexed the new territories without the consent of the Arab populations, nor the approval of the League. For MacCallum, the British and French actions not only violated the Anglo-French promise of November 1918, granting the Arabs their independence and an Arab Confederation as a reward for the Arab revolt against the Turks, ${ }^{189}$ but they had violated virtually every provision of Article 22 of the League Covenant, which guaranteed respect for the wishes of the indigenous population, the well-being of the people, and the rights of self-determination. ${ }^{190}$

\footnotetext{
${ }^{187}$ MacCallum, "The Class A Mandates, p. 1.

188 Ibid, p. 2.

${ }^{189}$ Ibid, p. 4.

${ }^{190}$ MacCallum, "The League and the Arab World," pp. 1, 7-8.
} 
MacCallum believed that imperial ambition had been most strongly felt in the Middle East because of its vast oil reserves, but because it was a key strategic location for all the competing powers. Iraq, said MacCallum, was the shortest route between Europe and India. Anyone who commanded Palestine held a crucial position in the defence of the Suez Canal. ${ }^{191}$

In "The League and the Arab World," MacCallum went even further in her criticisms of the Great Powers and the League. On behalf of the Arabs, she accused the League's Mandate System of defrauding Mesopotamian and Syrian Arabs of their independence; foisting a Jewish National Home under British military protection; and usurping the Arabs' natural resources. For MacCallum, the Mandates System pitted the territory's legitimate development against the Mandatory Powers' raw interests. ${ }^{192}$ What mattered, maintained MacCallum, was not the level of the territory's development, but the opportunities that the territories offered for European expansion. In a 1933 commentary in the Kingston Whig Standard, MacCallum concluded that the Mandates System "replaced colonialism in name only." 193

In 1935, MacCallum's prominence as a Middle East expert drew the attention of the World Peace Foundation, which invited her to prepare an historical study of Ethiopia in light of the threat of an Italian invasion. The project brought MacCallum back to

\footnotetext{
${ }^{191}$ Ibid. p. 13.

${ }^{192}$ MacCallum, “The Class A Mandates,” p. 9.

${ }^{193}$ Elizabeth MacCallum, Kingston Whig-Standard, Nov. 14, 1933, MacCallum Papers.
} 
political affairs and to New York. ${ }^{194}$ Yet her return was largely motivated by other considerations. As enjoyable as her spartan lifestyle had been in Uxbridge, it failed to provide the resources necessary to maintain her rural existence. In 1934, the farm had earned her a meagre $\$ 40.00$. As MacCallum recollected in the Gordon interview, "For five years, I built calluses on my hands until my resources evaporated. I had to go back to the other - the intellectual work - it was time." ${ }^{\text {"195 }}$ She also worried about the dangers that fascism presented. MacCallum was thoroughly convinced of the need publicly to address the rise of the dictators. ${ }^{196}$

Rivalries in Ethiopia, published in 1935, was MacCallum's attempt to set forth the essential facts and motivations behind the Italian-Ethiopian dispute. Instead of presenting the dispute as a quarrel between two powers, MacCallum explained how the international rivalries and imperial ambitions of Britain, France, and Italy shaped the dispute and dictated its outcome. Since the 19th century, stated MacCallum, "colony building . . . was one of the major preoccupations of European imperialist powers." This was particularly evident in Africa, where Britain, France, Belgium, Germany, and Italy wrestled for control of the continent's rich resources and strategic advantage. When the First World War broke out, there were practically no claims left unstaked in Africa, except for Ethiopia. MacCallum. explained the various means and methods that imperial

\footnotetext{
194 The World Peace Foundation was created in 1910 by Edwin Ginn to encourage international peace and cooperation. The Foundation sought to advance the cause of peace through study, analysis, and advocacy of wise action.

${ }^{195}$ Gordon Interview.

${ }^{196}$ Ibid.

${ }^{197}$ Elizabeth MacCallum, Rivalries in Ethiopia (New York: World Peace Foundation, 1935), p. 26.
} 
powers used to acquire commercial agreements or territory. In 1906, for example, Britain, France, and Italy signed a tripartite agreement specifying the spheres of influence in which each power would develop its own projects for opening up Ethiopia. ${ }^{198}$ Ultimately, she believed that Italy's failure to share in the spoils of Germany's defeat in the First World War was a strong motivator in its decision to invade Ethiopia in $1935 .{ }^{199}$

The second argument that Rivalries made regarded the imperial powers and the League of Nations. MacCallum believed that the colonial powers and the League of Nations and could not be relied upon to be good and reliable stewards of international security. Britain, which had a stake in the League's success, chose not to take action against Italy. The British much preferred a system of collective security to international anarchy, but they realized that by punishing Italy they opened themselves to similar censure. In the case of France, MacCallum argued that it too wanted the League to succeed, but it also appreciated that it might need Italy's and Britain's support against German expansion. MacCallum's message was clear; the League of Nations could not count on the Great Powers to resolve regional disputes.

After the publication of Rivalries, MacCallum was invited to prepare a series of radio talks and lectures on international affairs under the auspices of the World Peace Foundation, the League of Nations Association in the United States, the League of Nations Society in Canada, and the Canadian Institute of International Affairs. Her lecture subjects included: "The Origins of the Ethiopian Conflict," an historical analysis

\footnotetext{
${ }^{198}$ Ibid, p. 34.

${ }^{199}$ Ibid, p. 37.
} 
of Italian imperialism and Ethiopia's international position; "The Race Problem in Palestine," an assessment of the roots of the Arab-Jewish dispute; "Egypt's Share in the African Crisis," an examination of Anglo-Egyptian political relations, 1800-1930; and "The Struggle for Power in the Eastern Mediterranean," an exploration of Mediterranean problems in international diplomacy, $1886-1935 .{ }^{200}$ The range and scope of her talks confirmed MacCallum's reputation as a Middle Eastern authority, and underlined her commitment to international peace and security through public service.

In the spring of 1936, MacCallum returned to her Uxbridge farm for a period of restful contemplation. She pondered her next step. As she often told her friends and family, it was after a brief telephone conversation with her friend Charlotte Whitton, who counselled her to "get back to work," that she decided it was time to take up a position again." 201 However, she decided that she wanted to remain in Canada. There is no evidence that suggests a reason for this decision, although one can perhaps detect the stirrings of the Canadian nationalism that marked her later career. Wasting little time, she accepted the position of Head of Literature Services at the League of Nations Society in Canada, where she worked for the next four years. Under her direction, Literature Services was reorganized to supply information to teachers wanting to start international relations clubs in classrooms, to lawyers, to Members of Parliament, to study groups, to newspaper editors, and to other Canadians interested in international affairs. However, with the decline in League of Nations publications, and with the volume of work of the

\footnotetext{
${ }^{200}$ MacCallum Papers.

${ }^{201}$ Charlotte Whitton to Elizabeth MacCallum, [n.d.], MacCallum Papers.
} 
Literature Services greatly reduced, MacCallum resigned and joined the staff of the Canadian Legion Educational Services in 1941, where she helped establish libraries for Canadian servicemen and servicewomen in Canada and overseas. But she clearly felt that there was still more to do.

\section{Conclusion}

During the period 1925 to 1937, the richest period in her literary life, MacCallum in her capacity as a Middle East analyst produced more than thirty articles and three books on the region. This literary output represented a significant contribution to the study of Middle Eastern affairs during the interwar period, and a vivid portrait of her political attitudes. The central tableau of her narratives, and the crucible of her analyses, was that the Arab World was forever altered - politically, economically, and culturally — by Western imperial rivalries. MacCallum was convinced that the Arab World, and in particular, the Class A Mandate System, were tethered to British and French efforts to expand their empires in the region.

Through her commentaries and critiques, MacCallum depicted the disastrous effects of imperial policies. She believed that imperial actions provided the energy for an Arab nationalist movement. Britain's and France's continued "occupation" of Arab lands was anathema to most Arabs, and the catalyst for a renewed brand of a secular Arab nationalism that was dedicated to driving the imperial powers out of Arab lands. Western colonialism and imperialism were universally viewed by the Arabs as an obstacle to Arab unity, prosperity, and strength. As long as Western imperial interests were seen as 
irreconcilable with the Arabs' desire for independence, the region was going to be a powder keg, an explosion waiting to happen.

MacCallum also believed that the Great Powers' actions had distorted the Arab World's perceptions of what international institutions, notably the League of Nations, could be. The Arabs saw the League as little more than a willing partner in an imperialist scheme to steal their lands. As far as MacCallum was concerned, the Arabs were correct in believing that, under the League's cloak of legitimacy, Arab aspirations of selfdetermination, guaranteed under the League Covenant had, been denied.

MacCallum's most vocal opposition was reserved for Britain's Palestine policy. She was thoroughly convinced that Britain had created long-term animosities that would hamper Arab-Jewish relations. The British failed to understand the repercussions of entrenching two opposing and distinct nationalisms into a confined territory. To the Zionists, Palestine was the land of Israel — the birthplace of their faith. For the Arabspeaking inhabitants, who had been in possession of the land since the seventh century, it was legally and spiritually their land. The outcome, concluded MacCallum, was dysfunction and chaos, and the threat of civil war. It would spur all Arabs in a common crusade: driving out the Zionists. Britain's Palestine policy would inevitably consolidate many of the disparate Arab groups and states, which formerly had nothing in common with each other, and revitalize Islamist groups, which represented some of the most extreme nationalist groups in the region. The resulting violence would have repercussions throughout the world, insisted MacCallum, especially in countries where there were substantial Moslem or Jewish communities. Both Jewish and Arab groups made appeals 
to their communities, governments, and to the League of Nations. Believing that their petitions were ignored at the League, they turned to more radical alternatives. Monies were raised; and arms were purchased. This destabilized the region, forcing the British administrative authority in Palestine to increase its military presence and policing authority.

Western imperial interests, Arab nationalism, and the Arab-Jewish conflict over Palestine would be the prism through which MacCallum viewed the relationship between the West and the Arab world. She was forever suspicious of Great Power motivations in the region. These impulses fundamentally shaped her perceptions of the reliability of the League in defending the rights of smaller powers against the interests of the Great Powers. 


\section{Chapter 2 An Insider's (and a Male's) Department of External Affairs, 1942-1943}

MacCallum's fears had been fully realized. The League of Nations had failed to prevent international rivalries from erupting into violence. ${ }^{202}$ Japan had seized Manchuria in 1931, Italy had entered Ethiopia in 1935, and a rearmed Germany had swallowed Austria, Czechoslovakia, and Poland in 1938-1939. Another general war had erupted, twenty years after the end of the First World War. MacCallum had warned of the dangers of hyper-nationalistic fervour, and she had been right. Now she was not prepared to stand passively by. Instead, she needed to add her voice to the growing number of Canadian women who were actively working in support of the war effort. Women represented more than fifty per cent of the public service appointments made during the war, ${ }^{203}$ but their position was not an envious one - not if they wanted respect, equality, and advancement.

\section{Entering External Affairs}

In response to an invitation by Marjorie Mackenzie, the deputy minister's trusted assistant at the Department of External Affairs (DEA), to "share her talents", MacCallum considered an application to the Civil Service Commission (CSC), the government's central personnel organization. She was intrigued by the prospect of working for the department. External Affairs seemed the model of a modern and progressive foreign service, "distinguished by its talented recruits, sense of purpose, and influence on the

\footnotetext{
202 James Eayrs, In Defence of Canada: Appeasement and Rearmament (Toronto: University of Toronto Press, 1965), p. 159.

${ }^{203}$ Kathleen Archibald, Sex and the Public Service: A Report to the Public Service Commission of Canada (Ottawa: Public Service Commission of Canada, 1973), p. 16.
} 
gamut of national policy."204 It was the envy of the other federal departments. ${ }^{205}$ For MacCallum, it seemed the ideal job, with a charged atmosphere and bright, energetic colleagues, who possessed similar university backgrounds.

MacCallum undoubtedly had reservations. The job paid poorly compared to the Foreign Policy Association (FPA), a mere \$1,920 annually. It was all but an entry-level position. The hours would be long and the work intensive. There would be little room for advancement in a temporary wartime position, and the department prohibited women from becoming Foreign Service Officers. ${ }^{206}$ Nevertheless, External Affairs presented her with a possibility previously denied to women — to do a foreign service officer's work, even if only on a temporary basis. The position might even enable her to continue her study of the Middle East. ${ }^{207}$

Thus, on June 22, 1942, MacCallum submitted an application to the CSC. Her resume was strong. She had graduated from Queen's University with a double gold medal in English and History; she had studied with some of the most respected Canadian and American scholars, including O. D. Skelton at Queen's University and C. J. Hayes at Columbia; and she had a proven record in research and analysis, having produced three books and more than thirty articles on international relations. In addition, she was

\footnotetext{
${ }^{204}$ Barry Ferguson, Remaking Liberalism: The Intellectual Legacy of Adam Shortt, O. D. Skelton, W. C. Clark and W. A. Mackintosh, 1890-1925 (Montreal \& Kingston: McGill-Queen's University Press, 1993), p. 24.

205 J. L. Granatstein, The Ottawa Men: The Civil Service Mandarins, 1935-1957 (Toronto: University of Toronto Press, 1982), pp. 43-44.

206 "Certificate No. 66195," July 10, 1942, Civil Service Commission Papers, Library and Archives Canada (LAC), RG 32, Vol. 451, File: Elizabeth Pauline MacCallum.

207 Anne Hillmer, "Elizabeth MacCallum: Scholar, Diplomat, Teacher," Anne Hillmer Papers (July 10, 1985), p. 4.
} 
internationally recognized in Middle Eastern affairs, particularly in the areas of international law, the League of Nations' Mandate System, and the region's history. While possessing the proven skills of a specialist, she also had the broad knowledge of a generalist. Her abilities and skills were in keeping with the job requirements for foreign service officers initially established by Skelton when he became the head of External Affairs in the mid-1920s. ${ }^{208}$

MacCallum's references were equally noteworthy. The three men who spoke on her behalf were among the leading advocates of internationalism in Canada and the United States: H. M. Tory, the educator and former president of the League of Nations Society in Canada; ${ }^{209}$ J. E. Robbins, former director of educational services of the Canadian Legion's Literary Services; and Raymond Leslie Buell, senior editor with Fortune Magazine and former president of the Foreign Policy Association. Their recommendations provided External Affairs with information and insights into MacCallum's character and abilities. Their assessments shared a common judgment: MacCallum was skilled, intelligent, and principled. It was clear from their testimonials that her referees all believed she was more than capable of excelling in any organization or government department.

\footnotetext{
${ }^{208}$ K. A. McCloskey, "Memorandum to the Secretary of the Civil Service Commission," July 4, 1942, Civil Service Commission Papers, LAC, RG 32, Vol. 451, File: Elizabeth Pauline MacCallum. Also see: Assignment Branch of the CSC, "Memorandum to the Civil Service Commission," July 9, 1942, Civil Service Commission Papers, LAC, RG 32, Vol. 451, File: Elizabeth Pauline MacCallum. According to the Assignment Branch, MacCallum's appointment as Principal Clerk was approved effective July 1, 1942.
}

${ }^{209}$ E. A. Corbett, Henry Marshall Tory: Beloved Canadian (Toronto: The Ryerson Press, 1954), p. 2. 
To Henry Tory, MacCallum was a valued colleague and friend. For four years, she had been the chief executive officer of the Legion's International Literary Services. Her chief responsibility had been the selection of all of their educational materials, which were distributed to various Society branches throughout Canada. She worked closely with Tory to acquire a diverse and comprehensive collection of materials from leading international organizations. As a result, she became a trusted advisor, friend, and confidante to Tory. The most striking feature of his letter was his belief in MacCallum's eagerness to advise and educate others. He noted that, in addition to her routine duties, she regularly advised him and his senior staff about the most current trends and developments in international relations. Her discussion of the Service's new literature was always compelling. She could contextualize and cogently summarize the spectrum of intellectual ideas and movements of the day. In her conversations with Tory, he recalled, she summoned up contemporary trends in political economy, scientific and educational pedagogies, and political and international relations theory.

Tory sensed in MacCallum a natural-born teacher; he believed that she cherished the opportunity and challenge of training minds - young and old. Tory's letter also set out his belief that MacCallum was "particularly well-equipped to deal with matters concerning the Near and Middle East." ${ }^{210}$ In affiliation with the Chicago Adult Education Association, Tory had urged MacCallum to speak about Palestine to wartime American audiences in Illinois, Kansas, Minnesota, and Missouri. She needed little encouragement.

${ }^{210}$ H. M. Tory, "Letter to Civil Service Commission," June 23, 1942, Civil Service Commission Papers, LAC, RG 32, Vol. 451, File: Elizabeth Pauline MacCallum. 
Her years at the Foreign Policy Association had shown her the value of public debates. Through the FPA's "Luncheon Series," she came to understand that she could convey the dangers of splitting Palestine into Arab and Jewish nations and the choices that confronted the international community on the question of the Middle East. ${ }^{211}$

Like Tory, John Robbins had a long and close relationship with MacCallum that transcended the work place. With the strong support of Tory, she had joined Robbins' Canadian Legion's Educational Service (CLNS) to organize its library services. Her central task was to develop libraries in Canada and overseas for military personnel during the Second World War. Robbins had been a professional admirer of MacCallum for many years. He recalled meeting her in Ottawa, while he was on the committee directing the League's International Literary Services. Robbins had never known a harder working employee or a more devoted one. MacCallum was well-organized, self-reliant, and rarely needed direction or assistance. Yet, it was "her unusual aptitude for getting along with her co-workers" that caught his attention. This was particularly notable given MacCallum's preference for solitude. Robbins had witnessed these remarkable abilities over the years and believed that it "made her a most valuable employee in any position for which her wide training and experience prepared her." ${ }^{212}$ More than any other quality, Robbins respected MacCallum's principled approach. She had resigned from the

211 Elizabeth MacCallum, "Civil Service of Canada Application Form," June 22, 1942, Civil Service Commission Papers, LAC, RG 32, Vol. 451, File: Elizabeth Pauline MacCallum, p. 4.

212 J. E. Robbins, “Application of Miss Elizabeth P. MacCallum,” June 22, 1942, Civil Service Commission Papers, LAC, RG 32, Vol. 451, File: Elizabeth Pauline MacCallum. 
Canadian Legion when Robbins tried to impose lists of books for service members ${ }^{213}$ that ran counter to the recommendations of the Legion's professional librarians. ${ }^{214}$ This only amplified Robbins' impression of MacCallum, and in no way was an impediment to their friendship or his respect for her work. ${ }^{215}$

Of the three referees, Raymond Leslie Buell provided the strongest support for MacCallum's application. By June 1942, he had left the Foreign Policy Association and become an executive in the editorial offices of Fortune magazine. "I have the highest regard," he wrote, "for her meticulous scholarship as well as her ability to write clearly and persuasively." ${ }^{216}$ Her articles were clear accounts of recent events in the light of their proper antecedents, an excellent basis for work of the sort required by External Affairs. In the six years that MacCallum had worked for him in the FPA's Research Department, Buell had watched her develop into one of the organization's most trusted analysts. As a result, he gave MacCallum greater responsibilities and duties, which she accepted as challenges.

By 1930, MacCallum had become a regular participant in the organization's senior editorial staff meetings, where she assumed the responsibility for briefing the staff on international developments, and recommending the topics, authors, and proposed

\footnotetext{
213 John A. B. McLeish, A Canadian for All Seasons: The John E. Robbins Story (Toronto: Lester and Orpen Ltd., 1978), p. 107.

${ }^{214}$ MacCallum, "Civil Service of Canada Application Form,” p. 8.

215 Ibid.

${ }^{216}$ Raymond Leslie Buell, “Letter to Miss R. M. Walker, Civil Service Commission,” June 25, 1942, Civil Service Commission Papers, LAC, RG 32, Vol. 451, File: Elizabeth Pauline MacCallum.
} 
themes for future publications. ${ }^{217}$ In addition, she frequently drew the maps and created illustrations for the organization's publications. These assorted activities, said Buell, honed MacCallum's capacity to judge the shape and importance of international incidents. She helped to establish an institutional sense of balance in understanding the ever-evolving international landscape and ensuring that it was properly translated into print. Although never formally recognized for the role, she was the department's de facto principal editor.

It was MacCallum's rapid development as a Middle East analyst, however, that impressed Buell the most. In six years, her work had appeared in national and international newspapers, university textbooks, and U. S. State Department briefing notes. As Buell's letter affirmed, "she was regarded as one of the leading specialists on Middle Eastern affairs in the United States." ${ }^{218}$ Even after leaving the Foreign Policy Association, MacCallum continued to write for it. However, her name now was given special prominence in Foreign Policy Reports and her articles were reprinted, translated into French, German, Arabic, and Italian, and sold to other publications. Consequently, MacCallum was internationally recognized for her comprehensive examinations of contemporary Middle East issues. With the release of The Nationalist Crusade in Syria, in 1935, her profile grew in FPA publicity. ${ }^{219}$

\footnotetext{
${ }^{217}$ MacCallum, "Civil Service of Canada Application Form," p. 6.

${ }^{218}$ Buell, "Letter to Miss R. M. Walker."

${ }^{219}$ See Elizabeth P. MacCallum, "Great Britain and the Race Problem in Palestine," Foreign Policy Reports (FPR), Vol. 10, No. 13 (August 29, 1934), p.1.
} 
A second characteristic of MacCallum's skills that Buell's letter addressed was her capacity for work in any area of international relations. She is "at home in almost any field of international relations and politics," Buell asserted. ${ }^{220}$ Aside from editing all of the studies emanating from the FPA, she had, for example, published an article covering the Australian financial crisis of 1931, which underlined MacCallum's growing expertise in international political and economic affairs outside of the Middle East. ${ }^{221}$

Buttressed by these strong recommendations, External Affairs quickly responded to MacCallum's application. On July 1 1942, without the benefit of examination or interview, Marjorie McKenzie invited MacCallum to join the department as a Principal Clerk, Grade 4, pending a security check. Her hiring almost certainly had the personal stamp of approval of Norman Robertson, the under-secretary of state for external affairs. $^{222}$ But what kind of department was MacCallum entering? To understand that, we must leave her story and examine the history, role, and purposes of External Affairs as it had evolved to the early part of the Second World War.

\section{A Political Department, A Narrow Department}

External Affairs was a uniquely political department in the Ottawa context. Under the terms of the External Affairs Act of 1909, as amended in 1912, the prime minister was

\footnotetext{
${ }^{220}$ Buell, "Letter to Miss R. M. Walker."

221 See Elizabeth MacCallum, "The Australian Financial Crisis," FPR, Vol. 7, No. 14 (September 16, 1931), pp. 259-276.

${ }^{222}$ Hillmer, p.15. Also see: Agnes McCloskey, "Letter to the Secretary of the Civil Service Commission on the Appointment of Elizabeth MacCallum to the Department of External Affairs," July 4, 1942, Civil Service Commission Papers, LAC, RG 32, Vol. 451, File: Elizabeth Pauline MacCallum; "Memorandum to the Civil Service Commission from Department of External Affairs," July 9, 1942, LAC, Ibid.
} 
charged with authority for the department. ${ }^{223}$ No other department in the federal government was so closely associated with the prime minister: it was his department. As a result, suggested the department's official historian, John Hilliker, the department from its inception "depended for credibility on its ability to serve the objectives of the prime minister. . .."224 These objectives tended towards the domestic, not the foreign, and towards the cautious, not the adventuresome. For Prime Minister R. B. Bennett, the preoccupation had been the economy, and for Prime Minister Mackenzie King, it was national unity and Canadian autonomy.

When Bennett and the Conservatives came to power in 1930, they were deeply suspicious of the DEA's loyalties. They saw External Affairs as a "Grit nest," which used the Canadian foreign service as a tool to advance the Liberal Party's domestic agenda. As he saw it, Bennett needed to prevent the department from acting as an opposition beachhead in his bureaucracy and undermining his policies. The Trade Commissioner Service, in Bennett's estimation, could ably do the job in the department's stead. ${ }^{225}$ Bennett considered national autonomy a product of Liberal thinking, damaging the British Empire. Exports, not autonomy, should be Canada's main foreign policy concern, and the aim should be reconstructing the British Empire as an economic unit, reasoned the prime

\footnotetext{
223 "The Department of External Affairs Act," April 1, 1912, in Documents on Canadian External Relations (DCER), Vol. 1, 1909-1918, p. 12. Article 3 stated that: "The Member of the King's Privy Council for Canada holding the recognized position of First Minister shall be the Secretary of State for External Affairs, and in this Act he is hereafter referred to as "the Minister."

${ }^{224}$ John Hilliker, Canada's Department of External Affairs, Vol. 1, The Early Years, 1909-1946 (Montreal \& Kingston: McGill-Queen's University Press, 1990), p. 42.

${ }^{225}$ Laurent Beaudry, "Memorandum to O. D. Skelton," December 27, 1930, External Affairs Records, LAC, RG 25, Vol. 791. Beaudry examined the representation abroad of various Canadian Departments and concluded "that the only well-organized group of Canadian representatives was the Trade Commissioner Service."
} 
minister. ${ }^{226}$ This meant either repositioning Canada's foreign policy from one that advocated autonomy to one that supported the Empire, or dismantling External Affairs and replacing it with the more dependable Trade Commissioner Service. This made the department's future precarious at best. ${ }^{227}$ O. D. Skelton, the under-secretary of state for external affairs, cognizant of these threats, quickly and deftly shifted the organization's directions to meet the approaching storm. If Skelton and the department were to survive, they would have to prove External's value to Bennett and demonstrate the department's unconditional loyalty. ${ }^{228}$ Skelton jettisoned External's focus on international political developments and embraced a domestic and international economic focus. His breadth of knowledge and his ability to give non-partisan advice gradually established confidence between the prime minister and the department. ${ }^{229}$

Another shift in the department's activities resulted from Bennett's concern over the condition of the Canadian economy. When Bennett took power, he had found an economy in difficulty. What initially appeared in late 1929 to be a regionally-based agricultural slump proved, within months, to be a major economic collapse. ${ }^{230}$ In the months and years that followed, "the economy not only failed to recover but slid inexorably downward in what seemed an endless decline."231 Restoring business confidence and investment became the central objective of the new government's efforts

\footnotetext{
${ }^{226}$ Hilliker, Canada's Department of External Affairs, p. 77.

227 Ibid, p. 137.

228 Ibid, p. 138.

229 Ibid, p. 139.

${ }^{230}$ Kenneth Norrie, Doug Owram, J. C. Herbert Emery, A History of the Canadian Economy (Toronto: Thomson Canada Ltd., 2002), p. 317.

231 Ibid.
} 
and its foreign policy. Cutting costs was a major theme of Bennett's administration, ${ }^{232}$ and a key to restoring confidence was dramatically to reduce government spending. Therefore, Bennett used the old verities of "austerity" and a "balanced budget" to reform government. His first step was to pare down the public service by slashing public-works expenditures and shrinking the government bureaucracy. ${ }^{233}$ By 1932, he had abolished all permanent government positions then vacant, curtailed promotions or reclassifications, halted the appointment of additional staff, reduced salaries by ten percent, and instituted compulsory retirement for all those 65 years of age or older. ${ }^{234}$

While Bennett's shrinking of the public service did not seriously affect External Affairs in the short term, ${ }^{235}$ it did have long-term implications. Senior officers were spread too thin, and they were compelled to take on duties well beyond their areas of competence; staff shortages at the few foreign posts forced External to rely too heavily on British consular and diplomatic reporting for the content of their dispatches; muchneeded recruitment of new foreign service officers was constrained; and the expansion of foreign missions was deferred. ${ }^{236}$ To deter Bennett from engaging in further austerity measures within the department, Skelton assigned L. B. Pearson "the task of writing a

\footnotetext{
${ }^{232}$ Ibid, p. 328.

${ }^{233}$ Hilliker, Canada's Department of External Affairs, p. 148.

${ }^{234}$ J. E. Hodgetts, William McCloskey, Reginald Whitaker, and V. Seymour Wilson, The Biography of an Institution: The Civil Service of Canada, 1908-1967 (Montreal and Kingston: McGill-Queen's University Press, 1972), p. 150.

${ }^{235}$ External Affairs' share of the cost-cutting formula amounted to $\$ 15,000$, which was saved by enforcing retirement at 65 and cutting expenses at diplomatic posts.

${ }^{236}$ H. Gordon Skilling, Canadian Representation Abroad: From Agency to Embassy (Toronto: Ryerson Press, 1945), p. 235.
} 
defence of the department's functions and its establishments at home and abroad."237 Like a schooner tacking across a competitor's bow, Skelton and External adapted and swung their attention to meet Bennett's political agenda. They steered away from international affairs and justified their existence with a renewed sense of identity, stealing the wind from Bennett's policies.

From 1935, when he was returned to power, Mackenzie King's foreign policy and his role as minister of external affairs were also deeply rooted in domestic realities. He concentrated his energies on restoring the economy, maintaining national unity, and promoting Canadian autonomy. By the time he came back to office, the accumulated federal debt had risen to $\$ 4.5$ billion, and debt repayment consumed 43 percent of annual revenues - almost one of every two dollars of revenue went spent servicing the national debt. $^{238}$ King closely held to the old philosophy of holding down government expenditures, regardless of employment levels. Consequently, he did very little to alter the basic trajectory of Bennett's austerity policies until $1939 .{ }^{239}$

The prime minister's concern for national unity particularly shaped his perceptions and actions towards the department and foreign policy. King's official biographer, H. B. Neatby, asserted that national policies in the decade of the 1930 s were

\footnotetext{
${ }^{237}$ Hilliker, Canada's Department of External Affairs, p. 152.

${ }^{238}$ Norrie, Owram, Emery, A History of the Canadian Economy, p. 328.

${ }^{239}$ Ibid, p. 345. By 1939, the government's public service had been cut by more than ten percent, leaving little more than 45,000 federal employees, with nearly 12,000 of them delivering the mail.
} 
not easily devised. ${ }^{240}$ Regional and cultural cleavages, which had always existed, were intensified by the hard times. The nation witnessed the emergence of even more divisive regional and social tensions; new regional political parties challenged the federal party system; labour unrest spread fears of a radical social revolution; and the growing membership - albeit small — in fascist and communist organizations in Canada reflected a sense of discontentment and alienation among Canadians. King believed that controversies over foreign policy would lead to the unravelling of the Canadian fabric, as it had during the First World War. ${ }^{241}$

With a heightened sense of alarm about international entanglements, King and his Cabinet rebuffed most efforts made by Skelton to expand his personnel and Canada's representation abroad. Economic recovery and national unity considerations worked hand-in-glove to justify a cautious approach to foreign policy and the development of Canada's foreign service. King restricted the independent actions of his senior foreign service officers. He took the officers in hand and prohibited them from raising issues of foreign policy or issuing statements to the public without first consulting Skelton. ${ }^{242}$ Caution was the principal diplomatic doctrine of the Canadian foreign service.

\footnotetext{
${ }^{240}$ H. B. Neatby, "Mackenzie King and National Unity," in Robert Bothwell and Norman Hillmer (eds.), The In-Between Time: Canadian External Policy in the 1930s (Toronto: Copp Clark Publishing, 1975), p. 207.

${ }^{241}$ Ibid.

${ }^{242}$ Hilliker, Canada's Department of External Affairs, Vol. 1, p. 184.
} 
Like Bennett, moreover, King was convinced he had the right to call on any individual in the department if he required their services. ${ }^{243}$ This attitude had serious ramifications for a short-staffed department and resulted in the loss of some of its officers, such as J. W. Pickersgill, to the Prime Minister's Office. No provision was made to replace those lost on "temporary assignments." The department's character and agenda were influenced by the prime minister's political agenda, his personal suspicions, and the doubts and fears that seized his leadership. This meant that External made decisions that narrowed its range of policies and management choices. ${ }^{244}$

When Skelton became the under-secretary of state for external affairs in 1925, his guiding principle for a new service lay in shifting the department from a patronage- to a career-based foreign service. To accomplish this, he implemented a merit-based system for the recruitment, promotion, and posting of Canadian foreign service officers. Skelton saw the importance of the Civil Service Commission's recently implemented reforms, most notably the adoption of the merit principle. By using a system of empirically-based examinations, the merit system provided Skelton with the means by which the department could choose the best qualified personnel. It facilitated a foreign service where a person's achievements superseded their connections. ${ }^{245}$

\footnotetext{
${ }^{243}$ Norman Hillmer, O. D. Skelton: A Life in the Arena (Manuscript), see: Chapter 8: "Inching Towards Independence."

${ }^{244}$ Gilles Lalande, The Department of External Affairs and Biculturalism: Diplomatic Personnel (19451965) and Language Use (1964-1965), Vol. 3, Studies of the Royal Commission on Bilingualism and Biculturalism, (Ottawa: Government of Canada, 1965), pp. 1-2.

${ }^{245}$ Hillmer, O. D. Skelton: A Life in the Arena, Chapter 8: "Inching Towards Independence,"
} 
Yet the department remained plagued by inefficiency and often ineffectiveness. Skelton's management was complicated by his inability to delegate, to train officers in the diplomatic arts, or to know how to employ and control his officers in the field. In the case of recruitment, he had a limited concept of the type of personnel he wanted, and the skills that they should possess. The ideal candidate was someone like himself: a male Anglophone, a university graduate, and of professional type and demeanor. ${ }^{246}$

Skelton was also convinced that recruiting specialists was impractical. Forging External along specialist lines would have had an enormous impact on entrance requirements, promotions, and postings, and would have required a very different type of organizational model, because Skelton's approach to organizing the department adhered to neither geographic nor functional jurisdictions. ${ }^{247}$ Skelton decided instead to rely on generalists, scholar-diplomats, men "of all-round ability, capable of performing widely differing assignments at short notice. . .."248 His process of selection reflected a narrow approach, which effectively marginalized particular groups of candidates and created a rarefied elitist environment where Anglophone intellectuals were dominant within the organization. In an attempt to craft a department of state that would liberate Canada's foreign service from the cultural grip of the British Foreign Office, Skelton's department

\footnotetext{
${ }^{246}$ J. L. Granatstein, "Skelton, Mackintosh, Clark, Gordon and Deutsch," in Ann MacDermaid and George F. Henderson (eds.), Through Scholarly Eyes: Queen's University Archives Lectures, 1983-1991, (Kingston: Queen's University Press, 1991), p. 88. According to Granatstein, of the initial six candidates recruited in the 1920s and 1930s, five had post-graduate training, five of the six had taught at the university level, and two had doctoral degrees.

${ }^{247}$ Marcel Cadieux, The Canadian Diplomat, translated by Archibald Day (Toronto: University of Toronto Press, 1962), pp. 59-68.

248 James Eayrs, The Art of the Possible: Government and Foreign Policy in Canada (Toronto: University of Toronto Press, 1961), p. 53.
} 
adopted many of its shortcomings. Like the British foreign service, virtually all of Skelton's hand-picked candidates came from Britain's elite university system. ${ }^{249}$ Skelton's recruitment practices also paid little attention to the makeup of the country; ${ }^{250}$ it failed to reflect the country's bicultural nature or the increasing role that women were playing in the Canadian workplace.

\section{Gravitating Around Men}

The department's discrimination against women was overt, as was the government's. In the 1889 Report of the Royal Commission on the Relations between Capital and Labour, the evidence suggested that Canadian society found women's presence in the economy "an unfortunate corollary of industrial expansion." 251 The Royal Commission on the Civil Service of 1907-1908 was created, in large part, to address the problem of the growing number of women in the civil service. ${ }^{252}$ "The Commission perceived its problem," suggested social scientist Katherine Archibald, "not as one of keeping women down — that was taken for granted — but as one of keeping down the number of women in the civil service." 253

\footnotetext{
249 J. L. Granatstein, "The Anglocentricism of Canadian Diplomacy,” in Andrew Fenton Cooper (ed.), Canadian Culture: International Dimensions (Waterloo, ON: Centre on Foreign Policy and Federalism, University of Waterloo/Wilfrid Laurier University, Canadian Institute of International Affairs, 1985), p. 30.

${ }^{250}$ Ibid.

251 Sandra Burt, "The Changing Patterns of Public Policy," in Sandra Burt, Lorraine Code, and Lindsay Dorney (eds.), Changing Patterns: Women in Canada (Toronto: McClelland \& Stewart Inc., 1993), p. 215.

${ }^{252}$ Ibid, p. 48. By the time that the Royal Commission of 1907 was convened, there were 700 women inside the civil service in Ottawa, 23.3 percent of the public service's total workforce of 3000.

${ }^{253}$ Kathleen Archibald, Sex and the Public Service: A Report to the Public Service Commission of Canada (Ottawa: Public Service Commission of Canada, 1973), p. 14.
} 
With the rapid expansion of the manufacturing, finance, and trade sectors, the employment of women in Canada quickly grew during the first twenty years of the twentieth century. ${ }^{254}$ "The rise of corporate capitalism in Canada after 1900," stated Fortin and Huberman, "precipitated a revolution in the means of administration." It was during this cycle of growth that the modern office was born and where greater attention was paid to the management of bureaucracies. The introduction of the "scientific management" movement by American Frederick Winslow Taylor made the office the nerve centre of administration. Newer and larger enterprises began to invest in administration management. ${ }^{255}$ This new nexus required large numbers of clerks to maintain the office's factory-like operations. The routine and repetitious nature of the clerical work was unattractive to middle-class male clerks who wanted more upward mobility and comfortable salaries, both of which were not available in the new office. ${ }^{256}$ As a result, women's employment saw its greatest surge. ${ }^{257}$

Women were also making their presence felt in Ottawa's bureaucracies. The civil service's merit-based examinations attracted many women. They filled almost all the lower grades of the Post Office and the Department of the Interior. ${ }^{258}$ The government sensed that their growing numbers constituted a dangerous trend, a movement that had to

\footnotetext{
${ }^{254}$ Graham S. Lowe, "Women, Work and the Office: The Feminization of Clerical Occupations in Canada, 1901-1931," in Veronica Strong-Boag and Anita Chair Fellman (eds.), Rethinking Canada: The Promise of Women's History (Toronto: Copp Clark Pitman Ltd., 1986), p. 109.

${ }^{255}$ Nicole M. Fortin and Michael Huberman, "Occupational Gender Segregation and Women's Wages in Canada: An Historical Perspective," Canadian Public Policy, Vol. 28, Supplement: Occupational Gender Segregation: Public Policies and Economic Forces (May, 2002), p. S15.

${ }^{256}$ Lowe, "Women, Work, and the Office," p. 111.

${ }^{257}$ Ibid, p. 110.

${ }^{258}$ Government of Canada, "Royal Commission on the Civil Service," Report of the Commissioners (Ottawa: King's Printer, 1908), p. 14.
} 
be dealt with immediately or the civil service would be shortly overwhelmed by women. During the 1908 Civil Service hearings, numerous politicians and bureaucrats spoke out against the growing tide of women civil servants. Collectively, politicians and bureaucrats predicted administrative chaos if women came to dominate the public service. Of particular note was the perspective of Joseph Pope, soon to be External Affairs' first under-secretary of state, and Mackenzie King, then the minister of labour. Pope's testimony revealed a great deal about his attitude to women, and how he planned to shape the department's recruitment policies. In voicing his disapproval of the hiring of women, he echoed the government's concerns about the numbers of women in the workforce, adding that "it was doubtful whether the young ladies serving in his department as temporary clerks were worth their \$500 annual salary.",259

In 1908, the federal government took a series of steps to stem the surge of women entering government service by passing an amendment to the Civil Service Act. The amendment restricted women's role in the public service. Through the newly created Civil Service Commission, the government prohibited the promotion of women by establishing a new classification system for all jobs. ${ }^{260}$ The amendment established three divisions of civil service workers. The first division represented the upper echelon of civil servants. Its positions consisted of deputy heads, assistant deputy ministers, and the principal technical and administrative and executive officers, as well as lesser technical and administrative officers, including chief clerks. The second division consisted of

\footnotetext{
259 Allison T. Hardy, "Women: Always Diplomatic and More Recently Diplomats," International Perspectives (July-August 1976), p. 26.

${ }^{260}$ Hodgetts, McCloskey, Whitaker, and Wilson, The Biography of an Institution, p. 27.
} 
certain other clerks, having technical, administrative, or executive expertise. The third division consisted of clerical positions - secretaries, entry-level file clerks, and stenographers. Their duties included copying and filing. It was in this division that most women worked, and women placed in the third division were prevented from applying for positions in the first and second divisions. In 1910, the federal government inaugurated its second sweeping reform of the Civil Service Act. It classified all positions according to gender, defining first and second division positions as exclusively male. ${ }^{261}$

This deliberate strategy provided the institutional means for maintaining the gender-driven divisions in the structure of Canadian labour markets. Thus, a "job" became a gendered concept, whereby the government would maintain a two-tiered employment system throughout the public service. ${ }^{262}$ While the policy of occupational segmentation was not new to the private sector, it was a tool for the federal government to use in its efforts to control and shape the composition of its public sector. ${ }^{263}$ Since jobs were classified on gendered lines, women had no opportunity to advance their standing in the civil service. ${ }^{264}$

The third step taken by the federal government was to categorize all women's jobs as temporary positions. This act prevented women from petitioning for a reclassification of their job or increase in their pay scale. The government's chief

\footnotetext{
${ }^{261}$ Ibid.

262 Joan Acker, "Hierarchy, Jobs, Bodies: A Theory of Gendered Organizations," Gender and Society, Vol. 4, No. 2 (June 1990), p. 145.

${ }^{263}$ Lowe, "Women, Work, and the Office," p. 110.

${ }^{264}$ Fortin and Huberman, "Occupational Gender Segregation and Women's Wages in Canada: An Historical Perspective," p. S15.
} 
argument for taking these steps was that "women were not considered suitable for, or capable of, working at more responsible levels." 265 Hence, women were denied the right to compete openly with men through the civil service examination process. The 1912 Murray Report, asserted historian John Hilliker, "showed the approach had been successful: fewer women had been appointed, the third division had been reduced in size, and the promotion of women had become much more difficult."266

In 1918, the Civil Service Act was further amended to reinforce the government's discriminatory policies against women. It gave the CSC "explicit authority to limit competitions on the basis of sex, as well as age, health, habits, residence, moral character 'and other qualifications that are in the judgement of the Commission requisite to the performance of . . duties." ${ }^{267}$ Little would change for women in the public service until 1921, when the federal government's gender barriers were expanded to prevent married women from working for the federal government on a permanent basis. If they were married, prior to the legislation, they were compelled to resign. If they were needed, they would be rehired as temporary workers at a minimum wage level, where there was little job security. Government officials argued that the action was necessary in order to protect the economic and social health of the country. ${ }^{268}$ The government contended that this would ensure the equitable distribution of jobs and argued that it was acting in the best

\footnotetext{
265 Archibald, Sex and the Public Service, p. 14.

${ }^{266}$ Hilliker, Canada's Department of External Affairs, p. 48. Also see: Hodgetts, McCloskey, Whitaker, and Wilson, The Biography of an Institution, pp. 31-33.

267 Archibald, Sex and the Public Service, p. 16.

${ }^{268}$ Hodgetts, McCloskey, Whitaker, and Wilson, The Biography of an Institution, pp. 486-87.
} 
interests of the society writ large. ${ }^{269}$ In more precise terms, the government's job classification system assumed a gendered organization of domestic life and social production. Women's identification was with childbearing and domestic life. The policies brought forth by the CSC reflected the attitudes at External Affairs and the gendered character of government practices and society as a whole.

There was virtually no difference in practice between Joseph Pope, who supported the restrictive recruiting practices of the $\mathrm{CSC}$, and O. D. Skelton, who believed that women should only have a supporting role to play. Yet Skelton's canvas was larger, and so his blinkers were perhaps more surprising. He was building a new and innovative foreign service, one that could have reflected Canada's changing gender attitudes. It appears that Skelton's attitudes about women were largely shaped by the notions of a nineteenth-century patriarchal society. His "career and outlook gravitated around men, ${ }^{270}$ presuppositions that shaped his view of the differing worlds of men and women. He chose not to distance himself from discriminatory practices that ran contrary to the merit system that he so actively promoted. Few male bureaucrats, said historian Terry Crowley, "questioned the restrictions placed on women's advancement in the civil service." 271

\footnotetext{
${ }^{269}$ Archibald, Sex and the Public Service, p. 6. The government saw a potential conflict between married women's responsibility as caregivers, and their growing participation in the labour force.

${ }^{270}$ Terry Crowley, Marriage of Minds: Isabel and Oscar Skelton Reinventing Canada (Toronto: University of Toronto Press, 2003), p. 156.

${ }^{271}$ Ibid.
} 
From a purely intellectual perspective, Skelton understood the need for equality, as evidenced in his support for women's right to vote. ${ }^{272}$ However, he could not translate that generalized principle into the realm of his hiring practices. The department's foreign officer entry process prohibited women from competing for foreign officer positions. Only men could apply to become foreign service officers, and that remained Skelton's policy throughout his 16-year tenure as under-secretary. His decision was not solely based on civil service regulations, but on the belief that men naturally held positions of power. $^{273}$

\section{MacCallum's Entry into External}

MacCallum's hiring in 1942 was a recognition of her abilities and expertise. However, other reasons accounted for her recruitment into the department. The war had required External Affairs temporarily to relinquish some of its hidebound thinking, which had all but dismissed the substantial role women might take in the department. External's long-standing deficiencies — the lack of organizational structure to manage its workload in a systematic way, the out-of-proportion pressure placed on senior foreign service officers, and the department's tiny corps of professional personnel — were "ripe for adjustment after Skelton's death." 274 So too, slowly, were External's attitudes towards women.

\footnotetext{
${ }^{272}$ Ibid, p. 179.

${ }^{273}$ Ibid.

${ }^{274}$ Hilliker, Canada's Department of External Affairs, p. 243.
} 
The department had to make some hard choices following Skelton's death in 1941. ${ }^{275}$ For Norman Robertson, the department's newly appointed under-secretary, the demands put upon External Affairs by the outbreak of the Second World War almost brought the department to the point of breaking. Donald Page, long a departmental historian, wrote that the department was not prepared for war. ${ }^{276}$ Not only had External lost many men who wished to serve in the Canadian armed forces, but it was burdened with preparing and staffing new missions, providing the necessary resources to deal with ever-expanding international responsibilities, ${ }^{277}$ managing prisoner-of-war (POW) camps in Canada, dealing with increased passport applications, and coping with expanded diplomatic and military communications traffic. After a year of struggling to find staff, Robertson declared: "I am obsessed by the difficulties of staffing an expanding service, under wartime conditions."278

Frustrated by the Treasury Board's unwillingness to lift their freeze on the department hiring permanent positions, Robertson recalled that the British Foreign Office (FO), facing a similar increased wartime departmental workload and the absence of male

275 Ibid, p. 262. At the beginning of war in 1939, the DEA had 33 foreign service officers and 313 employees supporting 11 posts abroad. Yet by 1942, the department had 44 foreign officers and 333 staff members. See "Promotions and Salary Increases in the Department of External Affairs and the External Affairs Service," September 18, 1942, External Affairs Records, LAC, RG 25, File 134-A, p. 1. The Order-in-Council of May 18, 1940 (P.C. 32/1905) forbade the "hiring for permanent positions, reclassification of permanent civil servants, increases to temporary employees, and changes in the proportion of temporaries to permanents ... unless Treasury Board otherwise directs."

${ }^{276}$ Don Page, "Coping With a War: The Experience of the Canadian Department of External Affairs," in Sidney Aster (ed.), The Second World War as a National Experience (Ottawa: The Canadian Committee for the History of the Second World War and the Department of National Defence, 1981), p. 126.

277 J. L. Granatstein, A Man of Influence: Norman A. Robertson and Canadian Statecraft, 1929-68 (Toronto: Deneau, 1981), pp. 193-194.

${ }^{278}$ Hilliker, Canada's Department of External Affairs, p. 257. 
foreign service officers during World War One, recruited women to serve as temporary wartime clerks and assistants. ${ }^{279}$ In the immediate postwar period, the FO let most of the women go in order to accommodate the returning ex-Service personnel. With this policy in mind, Robertson initiated a recruitment drive in the fall of 1942 to hire universityeducated women, under the age of 35 , who could serve as grade 4 clerks. "The duties were advertised as administrative and secretarial, but a difficult entrance examination tested knowledge of Canadian and international affairs." ${ }^{280}$ After a rigorous examination and interview process, Kathleen Bingay, Agnes Ireland, Margaret Meagher, Hilda Reid, Dorothy Burwash, and Mary Dench were hired. John Hilliker noted that, once they were in the department, they were given the same duties as male third secretaries, ${ }^{281}$ but at only sixty percent of the probationary male third secretary's wages. ${ }^{282}$ That amounted to $\$ 1,620$ a year. The disparity in income did not sit well with women and some senior officers in the department. For John Read, the department's legal advisor, it was unjust. He considered it important in principle for women to be eligible for officer positions, providing that they were willing to make a permanent commitment to a career. ${ }^{283}$ When complaints about the disparity were made to the Civil Service Commission, the Commission was adamant in asserting that the women were being paid for the position

\footnotetext{
${ }^{279}$ Foreign \& Commonwealth Office, "Women in Diplomacy: The FCO, 1782-1999," History Notes (No. 6, May 1999), p. 5.

${ }^{280}$ Hilliker, Canada's Department of External Affairs, p. 257.

${ }^{281}$ Hector McKenzie, "Recruiting Tomorrow's Ambassadors: Examinations and Selection for the Foreign Service of Canada, 1925-1997," in Robert Wolfe (ed.), Diplomatic Missions: The Ambassador in Canadian Foreign Policy (Kingston: School of Policy Studies, Queen's University, 1998), p. 107. For further career details on these women, see: Department of External Affairs, External Affairs Register: Biographical Notes on the Officers of the Department of External Affairs (Ottawa: Department of External Affairs, 1962).

${ }^{282}$ Hilliker, Canada's Department of External Affairs, Vol. 1, p. 257.

${ }^{283}$ Ibid, p. 258.
} 
advertised, rather than for the work they actually performed. Yet while these openly discriminatory practices denied women equal status and equal pay, it afforded them a rare opportunity - an opportunity that was not lost on MacCallum.

Marjorie McKenzie was a crucial factor in Elizabeth MacCallum's hiring. McKenzie was in a position to influence staffing. As head clerk to the under-secretary, McKenzie's influence on the hiring of the deputy minister's administrative staff was undisputed; she was the principal administrator in the office of the under-secretary. In 1942, however, McKenzie's influence was threatened by attempts to reform the undersecretary's office and remove the recently-arrived MacCallum from her charge. Saul Rae, just recruited as the wartime assistant to the under-secretary, recommended to Robertson that MacCallum should "'be asked to compile the raw material of the Departmental Bulletin, under my guidance . . . since I am not able to give the time to it which it now deserves." ${ }^{284}$ The blunt McKenzie wasted little time in responding to Rae's proposal:

It's nice of Mr. Rae to give so much thought to arranging my future for me. I think, however, things will go more smoothly if he will continue to look after his own business and leave me to look after mine. I didn't get Miss MacCallum brought in here and hand over the more interesting half of my work to her just in order to load myself up with a lot of new work which doesn't interest me in the least, and which I'm much too lazy to tackle. ${ }^{285}$

McKenzie's pointed rebuttal captured her motivations for bringing MacCallum into the under-secretary's office. She saw MacCallum's work as inextricably linked to her own. McKenzie's vocational interest, stated Hilliker, "was not in the administrative

\footnotetext{
${ }^{284}$ Margaret Weiers, Envoys Extraordinary: Women of the Canadian Foreign Service (Toronto: Dundurn Press, 1995), p. 19.

${ }^{285}$ Ibid, pp. 19-20.
} 
process but in the substance of foreign policy." 286 MacCallum's hiring enabled McKenzie to distance herself from some of her routine duties but still control them. It also provided her with an opportunity to expand her position and focus more on policy. She saw MacCallum's expertise in international relations as a valuable asset in the pursuit of that role. For McKenzie, special assistants like Rae were attempting to outflank or marginalize her. As her memorandum to Rae clearly affirmed, she wanted MacCallum to work solely under her direction, where she could monitor and supervise all of MacCallum's activities.

McKenzie was also determined to expand the role of women in the Department beyond that of secretaries, stenographers, and clerks. She was certain that women were more than capable of performing the duties of foreign service officers. ${ }^{287}$ MacCallum's presence and qualifications gave force to the principle that women could do more than clerical work. Her hiring represented a step in increasing the number and quality of women in the department, and doubtless McKenzie hoped that the new under-secretary and the CSC would reconsider their stance on women foreign officers. ${ }^{288}$

\footnotetext{
${ }^{286}$ Hilliker, Canada's Department of External Affairs, p. 102.

287 Vivien Hughes, "Women, Gender, and Canadian Foreign Policy, 1909-2009," British Journal of Canadian Studies, Vol. 23, No. 2 (2010), p. 162. McKenzie was permitted to take the foreign service examination in 1930 on the condition it did not imply that she was entitled to apply for a Third Secretary position. Her principal motivation, suggested Hughes, was to prove that she was equal to the task. She tied for first place in the competition.

${ }^{288}$ Weiers, Envoys Extraordinary, pp.13, 23. In response to Josephine McNeill's appointment as Ireland's minister to The Hague, McKenzie sent a memorandum to Marcel Cadieux, Head of External Affairs' Personnel Division, noting the promotion and requesting its publication in the Department's 1950 weekly bulletin. McKenzie saw McNeill's success as benefiting all women. Undoubtedly, this was a view that she had embraced throughout her career. However, her note also was trying to make a point to Cadieux, who in 1948 wrote a memorandum on the selection of foreign service officers recommending the admission of only a small number of women. McKenzie's note ultimately ended up in a Library and
} 
To attract MacCallum's interest, McKenzie knew she had to offer her something more than clerical duties. McKenzie had enjoyed the job of preparing the undersecretary's weekly synopsis of international developments for the prime minister's attention. Established by O. D. Skelton in 1930, the weekly analysis was a summary of British Foreign and Dominion Office prints and dispatches, reports from Canadian posts abroad, and articles from foreign newspapers. ${ }^{289}$ The work had given McKenzie an opportunity to be involved in policy, even if on the margins. She was convinced that MacCallum, with her years of experience with the FPA, would be eager to assume responsibility for the task. Thus, MacCallum's job description was designed to dovetail with McKenzie's old duties. According to a departmental memorandum to the Civil Service Commission on July 9, 1942, MacCallum was to prepare briefs for the prime minister's attention on current and international affairs, and review and interpret current and international affairs for officers in the department, using the "most secret documents" and information supplied from officers abroad and drawing from newspapers and periodicals. ${ }^{290}$ In addition, MacCallum would prepare special research reports on areas of interest to the prime minister, work which would be overseen by McKenzie and the under-secretary. ${ }^{291}$ Yet McKenzie ensured that all the written work that emanated from MacCallum's desk would be vetted by McKenzie and anonymously authored. McKenzie

Archives Canada file labelled "Recruitment of Women as FSO's in External Affairs." See External Affairs Records, LAC, RG 25, Vol. 2489, F:156-F.

${ }^{289}$ Ibid, pp. 138-39.

${ }^{290}$ K.A. McCloskey "Memorandum to the Civil Service Commission from the Department of External Affairs," July 9, 1942, Civil Service Commission Papers, LAC, RG 32, Vol. 451, File: Elizabeth Pauline MacCallum.

${ }^{291}$ Gordon Interview. 
thus blunted any perceived or real threat to her status posed by MacCallum. She also ensured, consciously or not, that there would be little if any acknowledgement of MacCallum's efforts.

\section{Conclusion}

The national war effort, now in its third year, significantly altered landmarks in the country's cultural landscape. Women were being called upon to enter the country's workforce as an act of patriotism. Yet External's history reflected a deeply entrenched male bias. From its very beginning, its most senior officers rejected an equal role for women in the foreign service. They strongly believed women were incapable of doing the job of diplomats. External was not alone in this perspective. The British Foreign Office and the other diplomatic services barred women from their professional diplomatic corps. Unlike its subtle discrimination against francophones, which was apparent throughout the 1920s and 1930s and beyond, the department's attitude toward women was clear and unquestionable. O. D. Skelton, the principal architect of the modern Department of External Affairs, pushed hard for the organization to implement a merit-based system for recruitment, promotion, and posting. However, nowhere in his merit-based system did he imagine women possessing the right to compete with men for foreign service officer positions. His discriminatory practices went with his view of women's role in society.

Norman Robertson, who replaced Skelton after his sudden death in 1941, did not drift very far from Skelton's view of women in the foreign service. It was only with the acute wartime shortages of foreign service officers that he was forced to hire women to serve as temporary officers. From his point of view, their presence represented a stop-gap 
measure to address the department's short-term requirements. It was not an acknowledgment that women should be eligible for the Canadian foreign service. In all likelihood, their employment would be terminated at the war's end.

Along with External's gender bias, MacCallum confronted other obstacles upon her admission to the department. Skelton had organized the department according to subjects; he rejected the geographic or functional approach, seeking instead "generalists," men of all-round ability, capable of performing a variety of assignments. They would better represent the requirements of his organization. He believed that regional or subject specialists were impractical; they would take longer to train, and be more difficult to post. Until the department had acquired the necessary assets properly to utilize specialists, generalists would continue to dominate the recruitment of External's foreign service officers.

As a result, MacCallum's entry point was far shallower than she deserved. Gender- and specialization-biases would be impediments in the course of her career. Yet the war had forced the department temporarily to shed some of its previously held attitudes, allowing MacCallum gradually to function as a de facto officer of the department. She had the support of Marjorie McKenzie, who had been in External Affairs long enough to be an insider. No longer content with performing administrative duties, Mackenzie searched for someone who could take over some of her administrative duties so that she could pursue policy work. She also wanted to find someone who could demonstrate that women were just as capable as men in performing the duties of a departmental officer. McKenzie had found that person, even if she planned to keep her 
new charge under wraps. MacCallum was a clerk in a department of officers; a woman in a male-dominated sanctuary; a specialist in an office of generalists. She had a long way to go. 


\section{Chapter 3 A Voice Beginning to be Heard, 1944-45}

Elizabeth MacCallum's External Affairs career began as a soft whisper. Her duties were very different from her heady days in New York, where she was considered one of America's leading voices on the Middle East. Instead of writing, publishing, and speaking out, she was doing what many considered mundane work. ${ }^{292}$ She could have easily been disheartened by the nature of her early assignments, and the continued anonymity associated with those duties. However, rather than being discouraged and returning to New York, she focused on the task at hand and appreciated the importance of the moment. Given her commitment to public service, a contribution to Canada's war effort was undoubtedly foremost in her mind.

Anonymity was not a new companion for MacCallum. In her first two years at the Foreign Policy Association, many of her articles had been anonymously authored. Like an apprentice, she learned her craft at External Affairs. She had little craving for recognition. Instead, she thrived on the quiet pursuit of knowledge; the reward lay in the learning and the sharing. External offered her the rare opportunity to have direct access to diplomatic communications concerning the Middle East. She could continue studying the region, and have access to the network of Canadian foreign service officers and their collective experiences. In her recollections of the war years, she mused that public

\footnotetext{
292 Margaret Weiers, Envoy Extraordinary: Women of the Canadian Foreign Service (Toronto: Dundurn Press, 1995), p. 40.
} 
service liberated her from the need to publicize herself and her work: "a person had greater freedom to do good work if they were anonymous." 293

The bulk of her early responsibilities at External Affairs involved the preparation of the department's weekly summary of international developments, and of the monthly précis of Canada's war effort for the prime minister. The weekly summaries, often referred to as the "Review of External Affairs," 294 utilized British Foreign Office and Dominions Office briefings, American State Department announcements, and Canadian diplomatic dispatches and newspaper articles. From the available information, MacCallum distilled the essence of each country's military situation, as well as its diplomatic, political and economic activities. Presented in chronological order, the monthly report also recapped Canada's diplomatic and constitutional developments, military activities, economic measures, and internal security and public welfare activities. The work kept her cognizant of all the "real-time" developments transpiring in the Middle East and North Africa.

By February 1943, MacCallum's work was beginning to be noticed. In a memorandum to the prime minister, Norman Robertson, under-secretary of state for external affairs, acknowledged her contributions to the department and requested that her work receive proper compensation.

As I think you will have seen from her [MacCallum's] weekly Review of External Affairs, which she prepares for your information, she is a person

293 Diane Gordon, “Interview with Elizabeth MacCallum,” Oral History Project, Queen's University (October 15, 1977).

294 Norman Robertson, "Memorandum for the Prime Minister," February 23, 1943, External Affairs Records, Library and Archives Canada (LAC), RG 25, B2, Vol. 678, File: 136, p. 10. 
of superior qualifications who is doing valuable work. I think we drove too hard a bargain in engaging her at this salary, and I would recommend that her position should be classified to pay her a salary of $\$ 2,400 .{ }^{295}$

Shortly thereafter, her position was extended for an additional year. ${ }^{296}$ While her duties continued to focus largely on preparing written briefings, MacCallum slowly began to employ her specialized knowledge of the Middle East to help the department and the prime minister better appreciate the intricacies of Middle East politics, and Palestinian politics in particular.

\section{Britain's Early Palestine Policies and MacCallum's Reactions}

Prior to the Second World War, Canada had not established a formal policy towards Palestine ${ }^{297}$ and the Mandate, nor had it developed an official response to the contradictory official British policies on Palestine that emanated from London during the 1920s and 1930s. MacCallum, in contrast, had spent the last 15 years investigating the ebb and flow of British policy pronouncements on Palestine. She had studied, written, and spoken at length on the historical, political and economic dimensions of the Palestine

${ }^{295}$ Ibid.

296 "Civil Service Certificate No. 66195," Civil Service Commission Papers.

297 O. D. Skelton, "Letter to A. Abraham, President of the New Zionist Organization," June 2, 1937, External Affairs Records, LAC, RG 25. Vol. 1839, Part 1. Responding to Abraham's concerns about the partitioning of Palestine recommended in the British White Paper (1939), Skelton stated that: "The Palestine Mandate, however, is, as you are aware, entirely in the hands of His Majesty's Government in the United Kingdom and the decision as to future administration of Palestine must reside with that government." Also see: O. D. Skelton, "Memorandum for the Prime Minister," May 12, 1939, King Papers, LAC, MG 26, J4, C138736. Commenting on correspondence with A. J. Freiman, a prominent Zionist in Ottawa, Skelton told Freiman "that I did not imagine the Canadian Government would wish to offer any advice on the matter [British White Paper of 1939]." Also see: Hume Wrong, "Note for Cora Casselman," October 28, 1943, Anne Hillmer Papers. Wrong stated: "So far as I know the Canadian government has never taken a stand on the proposals in the British White Paper about immigration into Palestine." Cora Casselman was a Liberal Member of Parliament, member of the Canadian Palestine Committee, and a member of the Canadian delegation to the United Nations conference in San Francisco in 1945. 
Mandate. Her views were ultimately distilled into her 1944 Palestine memorandum for the Department of External Affairs.

In order to understand MacCallum's views on the British White Paper of 1939, it is necessary to examine the evolution of British policy — through the various royal commission findings and White Papers — and to assess MacCallum's reactions and thoughts based on her interwar writings. In constructing any policy regarding Palestine, it must be understood that the motivations and aims of British policymakers were influenced by the fact that the Arab, Moslem, and Jewish communities were not local entities but represented groups with religious and racial affinities throughout the world. ${ }^{298}$ The Jewish community in Palestine was a small portion of the Jewish diaspora. There were more than $12,000,000$ Jews worldwide. ${ }^{299}$ The Arab population that dwelled in the Ottoman Empire on the eve of First World War was in excess of 11,000,000. The Moslem population consisted of more than 100,000,000 people worldwide, with ninety percent of them residing in India. ${ }^{300}$ All these groups held Jerusalem as the wellspring of their faiths. Therefore, any policy considered in London regarding Palestine's fate immediately took on international dimensions. British policy not only had to be attentive to Arab, Moslem, and Jewish aspirations, as well as taking into consideration

\footnotetext{
${ }^{298}$ H. G. Chilton, "The British Chargé to the Secretary of State," in Foreign Relations of the United States (FRUS), 1922, Vol. 2, July 10, 1922 (Washington D. C.: Government Printing Office, 1938), p. 284. Chilton suggested that the British were conscious that "Palestine is the centre of a variety of religious interests, each one of them, considered separately, is world wide."

299 Royal Institute of International Affairs (RIIA), Great Britain and Palestine, 1915-1945 (London: RIIA, 1946), p. 1.

300 Şevket Pamuk, "The Ottoman Economy in World War 1," in Stephen Broadberry and Mark Harrison (eds.), The Economy of World War One (London: Cambridge University Press, 2005), p. 112.
} 
Commonwealth relationships and Britain's political and commercial rivalries with the other Great Powers.

Britain's interwar Palestine policy was also shaped by various international rivalries and wartime agreements. The year 1917 became a watershed year for Britain's Palestine policy, until then the basic constellation of rivalries among the European powers and religious communities in Palestine did not experience any dramatic changes. Each government acted within the context of its own Middle East policy; none seriously considered claiming Palestine and the Holy Land for itself exclusively. This was particularly true of Britain's Middle East policy. Even with the strong likelihood that the Ottoman Empire would be dismantled if the Triple Entente were victorious, the British government expressed little interest in obtaining Palestine prior to $1917 .^{301}$ Lord Kitchener, secretary of state for war, told the de Bunsen Committee of 1915 that "Palestine itself would be of no value whatsoever for the British." "302 The committee report subscribed to Kitchener's assessment, stating that there would be foreign opposition to any one country controlling Palestine. The committee, therefore,

${ }^{301}$ Earl of Oxford and Asquith, Memories and Reflections, 1852-1927, Volume 2 (Boston: Little Brown, and Company, 1928), pp. 70-71.

302 Elizabeth Monroe, Britain's Moment in the Middle East, 1914-1956 (Baltimore: John Hopkins Press, 1963), p. 29. On April 8, 1915, British Prime Minister H. H. Asquith established an interdepartmental committee to study and make recommendations regarding the future status of the Ottoman Empire during and following the First World War. The Committee was headed by Sir Maurice de Bunsen, former British ambassador to Spain and Austria, and included members of the Foreign Office, War Office and India Office, the Admiralty and Board of Trade. 
recommended that Palestine's destiny should be decided by way of special negotiations. $^{303}$

This position fundamentally changed with the end of H. H. Asquith's government in December 1916 and the ascension of David Lloyd George as British prime minister. As Middle East commentator Elizabeth Monroe stated, the prospect of creating a British Palestine appealed to Lloyd George. In early April 1917, the prime minister made Britain's new Palestine policy clear. He told Sir Mark Sykes, diplomatic adviser, "to make every effort for a British Palestine, to give no pledges to the Arabs, and do nothing to prejudice the Zionist movement." ${ }^{304}$ In other words, Lloyd George was preparing to set aside the pledges that Asquith's government had made to the Arabs, French, and Italians regarding Palestine. ${ }^{305} \mathrm{He}$ was adamant; a French Palestine was " "not to be thought of,"” nor was any condominium going to be negotiated with France regarding Palestine. ${ }^{306}$ With the issuance of the Balfour Declaration in November 1917, London had launched a new Middle East policy that was no longer limited to Britain's economic rights and to strategic needs in the region. However, not all British officials universally embraced this new approach. According to Middle East historian Jukka Nevakivi, on August 13, 1917,

\footnotetext{
303 Jukka Nevakivi, Britain, France and the Arab Middle East, 1914-1920 (London: The Athlone Press, 1969), p. 22.

304 Monroe, Britain's Moment in the Middle East, p. 37.

305 For details on Anglo-Italian wartime agreements see: Frank E. Manuel, "The Palestine Question in Italian Diplomacy, 1917-1920," The Journal of Modern History, Vol. 27, No. 3 (September, 1955), pp. 263-280.

${ }^{306}$ Earl of Oxford, Memories and Reflections, p. 78. On March 13, 1915, Asquith wrote that the only one in Cabinet who supported the annexation of Palestine was Lloyd George. "He did not care a damn for the Jews or their past or their future." Asquith believed that Lloyd George was outraged at the thought at allowing Holy Places "to pass into the possession or under the protectorate of 'agnostic, atheistic France."”
} 
the Imperial War Cabinet met and discussed the question of Palestine. Arthur Balfour, the British foreign secretary, voiced the opinion that "internationalization could not be avoided, [he] welcomed the idea of America sharing a condominium with Britain. This was the only way to exclude the French and Italians." ${ }^{307}$ Lloyd George disagreed. He favoured a one-power protectorate - if not Britain, then certainly the United States.

In October 1918, Lloyd George informed the War Cabinet that the Sykes-Picot agreement was "outdated and did not apply to current circumstances" — the common diplomatic excuse for revising a treaty agreement. In early December 1918, a few weeks after the armistice, French Premier Georges Clemenceau reluctantly, and with little choice, agreed to turn over Palestine and Mosul's rich oil fields to the British in exchange for Lebanon, Syria, and a percentage of Mosul's oil revenues. ${ }^{308}$

At war's end, stated British historian Jonathan Schneer, Britain ruled Palestine by virtue of military conquest. ${ }^{309}$ In April 1920, the San Remo Conference, which was only attended by Britain, France, Italy, and Japan, ratified Britain's control over Palestine indefinitely by awarding it mandatory authority. On April 25, 1920, the Conference adopted the British Mandate for Palestine resolution, which empowered the British with sole administrative control over Palestine, but also made them responsible for implementing the Balfour Declaration and Article 22 of the Covenant of the League of Nations. The Council of the League of Nations finally confirmed Britain's Mandate on

\footnotetext{
${ }^{307}$ Nevakivi, Britain, France and the Arab Middle East, p. 94.

308 John J. McTague, Jr. "Anglo-French Negotiations over the Boundaries of Palestine, 1919-1920," Journal of Palestine Studies, Vol. 11, No. 2 (Winter, 1982), p. 101.

309 Jonathan Schneer, The Balfour Declaration: The Origins of the Arab-Israeli Conflict (Toronto: Bond Street Books, 2010), p. 374.
} 
July 24, 1922, after Turkey had annulled the Treaty of Sèvres, which had partitioned the Ottoman Empire.

Sectarian violence engulfed Palestine shortly after the San Remo Conference. Arab and Moslem Palestinians were incensed by the inclusion of the Balfour Declaration in the Mandate agreement. In early June 1922, after witnessing two years of riots in Palestine, "in which 104 persons lost their lives and four times as many were wounded," 310 Sir Herbert Samuel, Britain's first high commissioner to Palestine, ${ }^{311}$ asked the Colonial Office to issue a statement clarifying the intent of the Balfour Declaration. ${ }^{312}$ Samuel, "the first Jewish ruler to exercise authority in the Holy land since the collapse of Shimon Bar Cochba's revolt against Rome in A. D. $133,{ }^{313}$ sought from the very start of his tenure to give greater precision to what was described by the Palestine High Court as a "political and not a legal document." 314 According to MacCallum, Samuel believed that the Arab unrest and their opposition to the Balfour Declaration were "based upon a

310 Elizabeth MacCallum, "Background of Unrest in Ancient Palestine," September 1, 1929, New York Times, p. xx4. For an account of the 1929 riots, see: Christopher Sykes, Crossroads to Israel: Palestine from Balfour to Bevin (London: Collins, 1965); John Marlowe, The Seat of Pilate: An Account of the Palestine Mandate (London: The Cresset Press, 1959).

${ }^{311}$ M. Mossek, Palestine Immigration Policy under Sir Herbert Samuel (London: Frank Cass \& Co., 1978), p. 1. Samuel was appointed High Commissioner to Palestine on July 1, 1920. For further detail on Samuel, see: Bernard Wasserstein, "Herbert Samuel and the Palestine Problem," The English Historical Review, Vol. 91, No. 361 (October, 1966.), pp. 753-775.

312 Elizabeth MacCallum, "Background of Unrest," p. xx4. Also see: Elizabeth MacCallum, "The Near East in 1928," Foreign Policy Association Information Service (FPAIS), Vol. 5, No. 4 (May 1, 1929), p. 72. According to MacCallum, "Article 14 of the mandate for Palestine provided that a special commission should be appointed by the mandatory to study, define and determine rights and claims in connection with the holy places."

${ }^{313}$ Wasserstein, "Herbert Samuel and the Problem of Palestine," p. 753.

${ }^{314}$ Norman Bentwich, Palestine (London: Ernest Benn Limited, 1946), p. 114. Also see: Herbert Samuel, "Memorandum for Cabinet: 'The Future of Palestine," January 15, 1915, The National Archives (TNA), Cabinet Papers, 37/123/43. Prior to becoming the high commissioner to Palestine, Samuel had called for the establishment of a Jewish state in Palestine under British protection. 
misunderstanding of its implications." ${ }^{315}$ By spelling out the intent and implications of the Balfour Declaration, Samuel hoped British officials would be able to "discourage exaggerated fears and exaggerated expectations" in the Arab and Moslem communities. $^{316}$

On June 3, 1922, responding to Samuel's request, Winston Churchill, the colonial secretary, outlined to the House of Commons his ministry's policy regarding the Balfour Declaration and the Palestine Mandate. ${ }^{317}$ Churchill's memorandum, commonly referred to as the Churchill White Paper of 1922, suggested that at no point was the intent of the Balfour Declaration to turn Palestine into a Jewish state. Nor did the declaration ever contemplate the disappearance or the subordination of the Arab population, language, or culture. Churchill further added that "Palestine as a whole was not to be converted into a Jewish National Home; a Jewish National Home was merely to be founded in Palestine." Yet, according to British historian Christopher Sykes, Lloyd George and Lord Balfour, had already agreed that the intent of the Balfour Declaration was always "an eventual Jewish State." ${ }^{18}$ Churchill stated that it was essential to understand that the Jews were in Palestine, not on suffrance, but based on their historic and spiritual rights. He further

\footnotetext{
${ }^{315}$ Elizabeth MacCallum, “The Palestine Conflict,” FPAIS, Vol. 5, No. 16 (October 16, 1929) p. 278.

316 Ibid.

317 Royal Institute of International Affairs, Great Britain and Palestine, 1915-1945 (Westport, Conn.: Hyperion Press, Inc., 1976).

318 Christopher Sykes, Crossroads to Israel: Palestine from Balfour to Bevin (London: Collins, 1965), p. 79.
} 
stipulated that the "Palestine community was to become a center in which Jews as a whole might take, on grounds of race and religion, an interest and pride."319

As MacCallum pointed out, Churchill's memorandum did little to allay Arab suspicions or fears. On the contrary, it increased Arab suspicions. They believed that Britain was going to open Palestine to large-scale Jewish immigration and help the Jews create a state of their own in Palestine. MacCallum was harsh in her criticism of Churchill's endorsement of the Jewish National Home policy, declaring that, while the Arabs tacitly accepted the principle that the Jewish community in Palestine had rights and should enjoy the same status as Arabs, they firmly opposed extending those rights to all Jews throughout the world, as Churchill's memorandum appeared to do. ${ }^{320}$ "No people, let alone the Arabs," passionately argued MacCallum, "would accept [such a policy] if applied to itself." 321 For MacCallum, Britain's ill-considered policy was also bound to accelerate Arab suspicions about Anglo-Zionist intentions. Richard Meinertzhagen, the British military advisor to the Colonial Office's Middle East Department, thought along similar lines when he predicted that Churchill's memorandum "would only aggravate the Arabs and embolden Zionist demands." ${ }^{322}$

For the next seven years, Palestine remained on the precipice of an all-out war. Nerves were frayed and tempers were short. In late August and the first half of September 1929, Palestine's simmering pot finally boiled over, violently erupting in the countryside

\footnotetext{
${ }^{319}$ MacCallum, "Background of Unrest," p. xx4.

${ }^{320}$ MacCallum, “The Palestine Conflict,” p. 285.

321 Ibid.

${ }^{322}$ Mossek, Palestine Immigration Policy, p. 71.
} 
and cities throughout the territory. In widely dispersed communities skirmishes and incidents broke out, MacCallum reported, and bands of Moslem Palestinians attacked Jewish settlers, looting, burning, and destroying Jewish property. ${ }^{323}$ The violence left 83 Moslems, 4 Christians, and 109 Jews, dead. These events prompted John Chancellor, the new British high commissioner to Palestine, to request that the British government establish a commission to investigate the "immediate causes which led to the outbreak in Palestine and to make recommendations as to the steps necessary to avoid reoccurrence." 324 The Commission on the Palestine Disturbance of August 1929, commonly known as the Shaw Commission, found that the lack of a clear-cut policy regarding the administration of the Mandate was the central problem. It urged the government "to formulate a comprehensive policy, to publish its decisions in precise and unmistakable form, to make it clear that in future no deviation from the declared policy would be tolerated, and to maintain in Palestine sufficient police and military forces to ensure respect for its decisions. $" 325$

The majority of the Shaw commissioners believed that Jewish immigration had been overly excessive, and had resulted in acute land shortages. ${ }^{326}$ It was also evident to the commission members, reported MacCallum, that Palestine could not support a large agricultural population until intensive cultivation had become more widespread. The

\footnotetext{
${ }^{323}$ MacCallum, "The Palestine Conflict,” p. 273.

${ }^{324}$ Pinhas Ofer, "The Commission on the Palestine Disturbances of August 1929: Appointment, Terms of Reference, Procedure and Report," Middle Eastern Studies, Vol. 21, No. 3 (July, 1985), p. 350 Also see: Elizabeth MacCallum, "Great Britain and the Race Problem in Palestine," Foreign Policy Reports (FPR), Vol. 10, No. 13 (August, 1934), p. 158. See also: Elizabeth MacCallum, "The Near East in 1928," FPAIS, Vol. 5, No. 4 (May 1, 1929), p. 72.

${ }^{325}$ MacCallum, "Great Britain and the Race Problem in Palestine," p. 160.

326 Ibid.
} 
Shaw Commission added that the eviction of Arab tenants, as a result of land sales to Jews, had created a discontented landless class that constituted a danger to public order. Therefore, the Commission recommended that "it was of the utmost importance that the British government should define explicitly the relative importance it attached to its obligations towards Jews on the one hand and Arabs on the other." ${ }^{327}$ In the meantime, the Commission recommended a suspension of Jewish immigration until a more comprehensive investigation of its effects on Arab farmers was completed.

The Arabs saw Jewish immigration as the principal means by which Zionists would dominate Arab lands and Palestine's economic and political levers of power. This was a perspective that MacCallum unreservedly shared. In her various articles, which surveyed the political and economic developments of the Middle East during the mid1920 s and throughout the 1930s, MacCallum anticipated the dangers associated with increasing Jewish immigration. ${ }^{328}$ She warned that the Arabs would refuse any attempt made by the Zionists and the British to expand the Jewish population or holdings in Palestine. The Arabs were committed, held MacCallum, to denying the Zionists numerical parity by all means necessary.

Shaw's report largely substantiated MacCallum's concerns that Arabs would eventually become a landless people in their own country. On March 30, 1930, an Arab

\footnotetext{
${ }^{327}$ Ibid, p. 161.

${ }^{328}$ See: Elizabeth MacCallum, "Survey Of Political Trends In The Near East, 1926," FPAIS, Vol. 2, No. 26 (March 2, 1927), p. 326; Elizabeth MacCallum, "Political And Economic Trends In The Near East, 1927," FPAIS, Vol. 3, No. 26 (March 2, 1928), p. 432; Elizabeth MacCallum, "The Palestine Conflict," FPAIS, Vol. 5, No. 16 (October 16, 1929), pp. 286-288; Elizabeth MacCallum, "The Near East in 1928," FPAIS, Vol. 5, No. 4 (March 1, 1929), p. 72; Elizabeth MacCallum, "Great Britain and the Race Problem in Palestine," Foreign Policy Reports (FPR), Vol. 10, No. 13, (August 29, 1934), pp. 160-164.
} 
delegation, fully appreciating Shaw's warning, met with British officials in London and demanded that the British government immediately halt all Jewish immigration to Palestine; declare all land in Arab possession inalienable; and establish immediately a Palestinian Legislative Assembly, in which all of the country's inhabitants would participate in proportion to their numbers. The Colonial Office and cabinet summarily dismissed the Arab demands out of hand, insisting that their request would prevent the British from carrying out their mandatory obligations. ${ }^{329}$

James Ramsay MacDonald, Britain's Labour prime minister, and Lord Passfield, the Colonial secretary, shared Shaw's concerns. They believed that Arab fears and anxieties would act as a catalyst for greater violence. MacDonald, however, was equally concerned about the political implications of supporting the Shaw report. It would undoubtedly prompt a lengthy and heated debate in the House of Commons that could fracture his fragile and divided minority government. In addition, he feared the possible repercussions emanating from the United States and the League's Permanent Mandates Commission. ${ }^{330}$ Therefore, to defer a final verdict on the question of Jewish immigration and land transfers, MacDonald proposed another commission to study the rate at which Palestine was able to absorb Jewish settlers without causing unemployment problems, the possibilities of Jewish settlement without evicting Arab cultivators, and the extent to which improved agricultural methods could be made available to support a larger

\footnotetext{
${ }^{329}$ H. L., "Great Britain and Palestine,” Bulletin of International News, Vol. 7, No. 8 (October 8, 1930), p. 7.

${ }^{330}$ G. Scheffer, "Intentions and Results of British Policy in Palestine: Passfield's White Paper," Middle Eastern Studies, Vol. 9, No. 1 (January, 1973), p. 46.
} 
population than at present. ${ }^{331}$ John Hope Simpson, a former administrator in India and known for his work on the question of refugees, was selected as Britain's one-man commission.

The Hope Simpson report, officially known as the Report on Immigration, Land Settlement and Development, found, in MacCallum's words, that there were "no large areas of vacant land which could be made available for Jewish settlement."332 Consequently, he recommended "a systematized, long-range scheme of development, aimed at intensive cultivation of land. . . Only after years of effort would this program result in a contraction of the area required by Arab cultivators and the release of a new margin of land for Jewish settlement." 333 The report concluded that "no transfers of land should be permitted, which would interfere with the general development scheme or result in further displacement of Arab cultivators." While Simpson did not call for an outright freeze on Jewish immigration, he urged that immigration should be limited to settlements or land reserves already held by Jewish organizations. With regard to illegal immigration, Simpson's report acknowledged that:

a large number of persons, amounting to some thousands each year, secured admission to the country in the guise of travellers. . . .It may be a difficult matter to ensure against this illicit immigration, but steps to this end must be taken if the suggested policy is adopted, as also to prevent unemployment lists being swollen by [Arab] immigrants from Transjordania. ${ }^{334}$

\footnotetext{
${ }^{331}$ MacCallum, “Great Britain and the Race Problem in Palestine,” p. 161.

332 Ibid.

333 Ibid.

334 John Hope Simpson, Palestine: Report on Immigration, Land Settlement and Development, Cmd. 3686 , October 1, 1930 (London: His Majesty’s Stationery Office, 1930), p. 120.
} 
In a private dispatch to Lord Passfield, Simpson made it known that he believed that Whitehall and the Palestine government had been derelict in their obligations to the non-Jewish population. He further suggested that both governments acted as spectators in the growth of the Yishuv, ${ }^{335}$ whose rapid expansion, he claimed, had been injurious to the non-Jewish population of Palestine. ${ }^{336}$ In his most serious condemnation of the two governments, Simpson declared that they "had not taken on serious steps towards the development of the country," a failure that contributed to the deplorable situation of the fellahin - the Arab farmer. For Simpson, this was the root cause of all the difficulties in Palestine. Wasting little time, the Jewish leaders in the Yishuv denounced the Hope Simpson report, insisting that it had ignored Palestine's capacity for industrial growth, a sector that would have long-term benefits for both Jews and Arabs. ${ }^{337}$ Once again, MacDonald backed away from action.

However, even before the final version of Simpson's report had reached the prime minister's desk, the secretary of state for the colonies, and a Cabinet committee had drafted the long-awaited British policy on Palestine. The White Paper of 1930, better known as the Passfield White Paper, was the fulfillment of Hope Simpson's recommendations. The Passfield paper called for a statement that would clarify the unresolved questions concerning the Palestine Mandate and the Balfour Declaration. MacCallum reported Passfield's four declarations: it rejected the Zionist view that the Palestine Mandate's principal purpose was the establishment of the Jewish National

\footnotetext{
335 Terms refers to the Jewish settlement in Palestine.

336 Scheffer, "Intentions and Results of British Policy in Palestine," p. 51.

337 Ofer, "The Commission on the Palestine Disturbances of August 1929," p. 354.
} 
Home, and that the passages designed to safeguard the rights of non-Jews were merely secondary considerations; it recommended the establishment of a Legislative Council along the lines indicated in the 1922 White Paper; it endorsed Hope Simpson's recommendation that a more methodical approach to agricultural development should be implemented; and it said that the British high commissioner should have greater control over legal and illegal Jewish immigration. ${ }^{338}$

As MacCallum summarized it, the Passfield report made it very clear that the "mandatory must be the deciding authority in immigration policy." 339 If the immigration of Jews prevented the Arab population from obtaining the work necessary for its maintenance, or if Jewish unemployment unfavorably affected the general labour position, then the mandatory must reduce or suspend immigration. ${ }^{340}$ Strictly speaking, the economic capacity of the country to absorb new immigrants must be judged in relation to unemployment in Palestine as a whole. This was undoubtedly a direct threat to the Jewish Agency's control over immigration and their aspirations for Jewish statehood. In addition, the report criticized the Jewish Agency and its subordinates for adopting a policy that prevented Arab labour from participating in any Jewish enterprise. Moreover, it accused the Jews of trying to impose a new social order on Palestine. ${ }^{341}$

The White Paper of 1930 unleashed a torrent of condemnations against Lord Passfield and MacDonald's government, noted MacCallum. The Zionist leadership was

\footnotetext{
${ }^{338}$ MacCallum, "Great Britain and the Race Problem in Palestine," p. 162.

${ }^{339}$ Ibid

${ }^{340}$ Ibid.

${ }^{341}$ Ibid.
} 
outraged by the British decree. The Times (London) stated that there was no comfort to be found in the policy for "those uncompromising Zionists who pressed successive British governments to permit unrestricted Jewish immigration, and transfer all state lands to Jewish colonists, in the hope that Palestine may thus become not only a Jewish National Home but a mainly Jewish State." 342 Dr. Weizmann, the president of the Zionist Organization, saw the Passfield policy as a "concerted effort ... on the part of the British government to retract the promise made to the Jewish people in the Balfour declaration." 343 Upon receiving an advanced copy of the Passfield text, Weizmann immediately recognized the ramifications of the new policy's restrictions on the Yishuv. In an October 21, 1930 open letter to The Times, the Zionist president said the Passfield programme represented a "profound change in the policy of 1922 [the Churchill White Paper]" and went a long way in "denying the rights and sterilizing the hopes of the Jewish people in regard to the National Home in Palestine." ${ }^{344}$ Moreover, as he pointed out in his 1949 autobiography, the policy confirmed that the British were attempting to extricate themselves from their Balfour and Mandate pledges. Weizmann knew full well that "it would crystallize the Jewish National Home at its present stage of development," words exactly the same as MacCallum's analysis of Passfield, the difference being that MacCallum approved of the policy and Weizmann emphatically did not. ${ }^{345}$ In practical

\footnotetext{
342 "British Policy in Palestine," The Times, October 21, 1930, p. 15.

${ }^{343}$ Chaim Weizmann, Trial and Error: The Autobiography of Chaim Weizmann, Vol. 2 (Philadelphia:: The Jewish Publication Society of America, 1949), p. 335.

344 "Palestine: A Statement of Policy," The Times, October 21, 1930, p. 15. Also see: MacCallum, "Great Britain and the Race problem in Palestine," p. 162.

${ }^{345}$ Weizmann, Trial and Error, p. 334; MacCallum, “Great Britain and the Race Problem in Palestine,” p. 162.
} 
terms, the future development of the Yishuv had been brought to an abrupt standstill with the introduction of the Passfield policy.

The international backlash was equally harsh. American Jewish leaders threatened to organize an unspecified anti-British campaign. Jan Smuts, the former prime minister of South Africa and an ardent supporter of a Jewish State, cabled MacDonald and declared that "the Balfour declaration was an international agreement which could not be modified by unilateral British action." ${ }^{346}$ In Britain, the MacDonald government received equally harsh denunciations of its White Paper. In a joint letter from Stanley Baldwin, Sir Austen Chamberlain, and Leo Amery to The Times, the three leading Conservatives stated that "a change of emphasis was required in the document to bring it into harmony with former announcements." 347

In what was clearly a disappointing setback for the Arabs and MacCallum, MacDonald's government retreated from Lord Passfield's policy. In a February 13, 1931 letter to Dr. Weizmann, commonly known in the Arab World as the "Black Letter," MacDonald tried to mollify the Jews by repudiating, point by point, everything asserted in Passfield's policy. ${ }^{348}$ The prime minister acknowledged that the Mandate was an obligation, not only to those Jews living in Palestine, but to all Jews worldwide. His letter further pledged that the Palestine administration would minimize its interference with the transfer of lands. In doing so, MacDonald ignored Shaw's and Simpson's considered

\footnotetext{
${ }^{346}$ MacCallum, “Great Britain and the Race Problem in Palestine,” p. 162.

347 Weizmann, Trial and Error, p. 334.

348 J. C. Hurewitz, The Struggle for Palestine (New York: W. W. Norton \& Company, Inc., 1950), p. 22.
} 
opinions about the causes of Arab unrest. He pointed out that the proposals for ameliorating Arab conditions did not imply placing limits on Jewish aspirations. ${ }^{349}$ This proved to be a dangerous and short-sighted concession. Dr. Weizmann noted in his memoir, Trial and Error, that as a response to MacDonald's letter, Jewish legal immigration into Palestine was permitted to reach 40,004 in 1934 and 62,000 for $1935 .{ }^{350}$ The prime minister promised further that an inquiry would be undertaken to discover what state lands could be used for close settlement by the Jews. ${ }^{351}$ The promised inquiry was carried out by Lewis French, the newly appointed director of the Development Department in the Colonial Office. His findings, Reports on Agricultural and Land Settlement in Palestine, ${ }^{352}$ reiterated the central conclusion reached in the Simpson report; that is, that there were "no state lands available for the settlement of either Jews or landless Arabs." 353 French's report added that the Arab farmers had to be protected from eviction. The Jewish Agency rejected French's findings in 1932, as did the MacDonald (now national) government.

Following the withdrawal of the Passfield White Paper, there was little doubt in MacCallum's judgment that the British government was under tremendous pressure from

\footnotetext{
349 Ibid, p. 163. Also see: Weizmann, Trial and Error, Vol. 2, p. 335. Weizmann believed that the letter "rectified the situation," and that it was an "official reversal of policy."

350 MacCallum, "Great Britain and the Race Problem in Palestine," p. 165. According to MacCallum, Jewish immigration rose from approximately 7,000 in 1932 to 33,000 in 1933.

351 Ibid, pp. 163-164. French added that the Arab farmers had to be protected from eviction. The Jewish Agency rejected the French findings in 1932. The British response was a $£ 2,000,000$ loan to Palestine to resettle displaced Arabs, plus other infrastructure projects.

352 Ibid, p. 163.

${ }^{353}$ For a detailed examination of Britain's agricultural policy in Palestine, see: Roza I. M. El-Eini, "The Implementation of British Agricultural Policy in Palestine in the 1930s," Middle Eastern Studies, Vol. 32, No. 4 (October, 1996), pp. 211-250.
} 
pro-Zionist forces to maintain the status quo in Palestine. Britain's lack of decisiveness concerned MacCallum. After almost a decade of writing about the Palestine Mandate and Arab unrest, MacCallum had seen little effort on the part of British government to resolve the inconsistencies and contradictions inherent in the Mandate. Whitehall had failed or was unwilling to construct a durable policy that defended the interests of both national communities in Palestine. At the heart of the British problem, believed MacCallum, was the Balfour Declaration. It had proven to be a profound miscalculation, in principle and practice. Balfour had prevented British officials from creating a structure of local government that would accommodate both national communities in Palestine, as they had done in Iraq. Even with an overwhelming body of evidence that substantiated the view that the aims of the Jewish National Home policy were at variance with the principles of the Mandates System, the interests and welfare of Palestine's majority population, and the collective advice of three royal commissions, the British government remained unwilling or incapable of extricating itself from the commitments made to the Zionists. As John Marlowe pointed out in The Seat of Pilate, after years of turmoil and Arab unrest in Palestine, the British government had not come to grips with eliminating impediments to Palestinian peace. The British were unwilling to take the necessary steps to curb Jewish immigration, land transfers, or the encouragement of Arab development. ${ }^{354}$

\footnotetext{
${ }^{354}$ Marlowe, The Seat of Pilate, p. 129.
} 
Britain's indecisiveness on a Palestine policy also indicated to MacCallum an absence of consensus or an overarching vision for the country. ${ }^{355}$ Professor Albert Hourani, a British-Lebanese historian specializing in the Middle East, stated that:

There was no adequate machinery for forming a [Middle East] policy, no proper co-ordination between the two different departments concerned with the Arab countries, no central responsibility for decision. The conceptions of the Foreign Office, the War Office, the Cairo Residency and the Government of India were not wholly in agreement with one another, and each carried on its own policy with at most an imperfect agreement with the rest. ${ }^{356}$

With no clear-cut lines of authority, the Colonial and the Foreign Offices were often left competing for control of the Mandate policy. ${ }^{357}$ At the end of the day, this clash exacerbated organizational rivalries and undermined the government's ability to produce a clear and concise policy on Palestine. In practical and political terms, without a clearlydefined policy that addressed both Arab self-rule in Palestine and limited Jewish immigration on a scale that would not endanger the economic, political, and cultural development of the Arabs, MacCallum feared that a radicalizing nationalist fervour would result and go largely unchecked by the British. ${ }^{358}$ By 1934, it was apparent to MacCallum that events would soon unravel the Palestine Mandate, as Britain's efforts to

\footnotetext{
355 Elizabeth MacCallum, “The Arab Nationalist Movement," FPR, Vol. 11, No. 5 (May 8, 1935), p. 55. For information on the lack of unity in the British government, see: Albert Hourani, Great Britain and the Arab World (London: J. Murray Publishers, 1945) p. 19; Aaron S. Klieman, "The Divisiveness of Palestine: Foreign Office versus Colonial Office on the Issue of Partition, 1937," The Historical Journal, Vol. 22, No. 2 (June, 1979). With respect to Britain's Middle East policy, the Colonial Office maintained responsibility for the mandated territories of Iraq, Palestine, and Transjordan as well as Aden, while the Foreign Office was responsible for conducting relations with the independent states of the region. Britain's Middle East defence policy was overseen by the Air Minister, but the Admiralty was responsible for the problems of strategy and defence in the Persian Gulf.

${ }^{356}$ Hourani, Great Britain and the Arab World, p. 19.

${ }^{357}$ Ibid.

${ }^{358}$ MacCallum, "Great Britain and the Race Problem in Palestine," p. 167.
} 
maintain the status quo became more and more difficult. ${ }^{359}$ Britain's lack of progress on meeting Arab demands convinced MacCallum that the British had failed to appreciate the extent of Arab anger over the continued immigration of Jews into Palestine.

In her final article for the Foreign Policy Association in 1935, and the last comment that she would make on Palestine before entering the Department of External Affairs, MacCallum warned the West of the imminent dangers associated with the suppression of Arab rights, and with the growing extremism in the ranks of the Arab movement. Palestine, in her judgement, had become the epicenter of the Arab awakening. It was here that the Arab desire for emancipation from foreign control was most keenly felt. ${ }^{360}$ Patriotic clubs and secret societies were quickly forming; nationally organized demonstrations and boycotts were held; religious agitation campaigns targeted both agricultural and urban centers; and anti-Mandate and anti-Jewish propaganda thrived. ${ }^{361}$

\section{The Arab Rebellion, Peel, and Woodhead}

For MacCallum and the Arabs, the MacDonald government's abandonment of the Passfield report and the findings of its royal commissions indicated Britain's unwillingness to treat the Arab claims justly. ${ }^{362}$ Report after report supported the Arab case, and yet nothing concrete was done to address their grievances. Arab leaders were convinced that the British government was so much under the influence and control of

\footnotetext{
359 Ibid, p. 167.

${ }^{360}$ MacCallum, "The Arab Nationalist Movement," p. 54.

${ }^{361}$ Ibid, p. 55.

362 Frank C. Sakran, Palestine Dilemma: Arab Rights Versus Zionist Aspirations (Washington, D. C.: Public Affairs Press, 1948), p. 137.
} 
the Jews that their case would never be given a fair hearing. ${ }^{363}$ Moreover, the lack of action in curtailing Jewish immigration indicated that Britain was steadfastly committed to furthering the Jewish National Home, and quite possibly, assisting the Jews in creating their own state in Palestine.

By 1935, Arab feelings of resentment had reached their zenith following an unprecedented wave of Jewish immigration during 1933-1934. Middle East Historian John Marlowe suggested the "tempo and bitterness of Palestine Arab nationalism increased pari passu with the increase in Jewish immigration." ${ }^{364}$ In sheer numbers, illegal and legal Jewish immigration in 1933 was in excess of 52,727. ${ }^{365}$ It constituted the second-highest total since the introduction of the British Mandate. The Arabs no longer viewed Jewish immigration as a "creeping conquest"; it was now a landslide that threatened to cover all their lands and property. As MacCallum had predicted, Jewish immigration became the most dangerous threat to the Palestinian future. According to a report sent to the Colonial Office, the Palestinian administration warned that the Arab attitude appeared "to have crystallized in the concept that the so-called Jewish policy of the mandatory is but a screen for oppressive imperialism and an excuse for withholding from the people of Palestine their elementary right of independence.”366

\footnotetext{
${ }^{363}$ Lord Peel, "The Report of the Palestine Commission," International Affairs, Vol. 16, No. 5 (September, 1937), p. 762.

${ }^{364}$ Marlowe, The Seat of Pilate, p. 131.

365 W. F. Abboushi, "The Road to Rebellion: Arab Palestine in the 1930s," Journal of Palestine Studies, Vol. 6, No. 3 (Spring, 1977), p. 26. In 1933, legal immigration jumped to 30,327, while illegal immigration accounted for an estimated 22,400.

${ }^{366}$ Marlowe, The Seat of Pilate, p. 131.
} 
In March 1933, with more than 500 Arab delegates in attendance, the National Arab Congress met in Jaffa, Palestine, to discuss the British government's growing indifference to Arab demands, and the risks associated with its Jewish National Home policy. The Congress charged that the purpose of Britain Mandate policy was "to pave the road for driving the [Arab] nation away from its homeland for foreigners to supersede it." ${ }^{367}$ The Congress, therefore, charted a new course for Arab diplomacy. It would no longer co-operate with the British government in Palestine, and, consequently, it laid out a manifesto that called for open defiance of the British Palestine administration's authority.

The tipping point for the Arab rebellion came in 1935, when British customs officials discovered a shipment of arms and ammunition secreted in a consignment of cement from Belgium to a Jewish firm. Arab newspapers described the cache as enough weapons to meet any possible Arab attack. In protest, the Arabs declared a general strike for October 26, 1935, and presented a formal petition to the high commissioner repeating their demands for the establishment of a democratic form of government; prohibition against the further transfer of land to Jews; the immediate stoppage of Jewish immigration; and the creation of a committee to ascertain the absorptive capacity of the country, in accordance with the policy laid down in the Churchill White Paper of 1922. The Arab request met harsh opposition in the British Houses of Lords and Commons. On March 24, 1936, the British government rejected the Arab demands, arguing that the

\footnotetext{
${ }^{367}$ Esco Foundation, Palestine: A Study of Jewish, Arab, and British Policies, Vol. 2 (New Haven, Conn.: Yale University Press, 1947), p. 768.
} 
Arab people were not ready for self-government. When news reached Jerusalem that the British government had rejected the Arab demands, the Arab revolt began. The anger quickly turned into a widespread rebellion against the Mandate and the Mandatory power. The rejection of Arab demands was in line with MacCallum's analysis of the problem: broken promises had been heaped on broken promises.

The British, with practiced precision, responded swiftly and harshly to the Arab insurrection. Collective punishment, and punishment by association, were the common features of the British response. British military forces jailed relatives of Arab guerrillas, imposed collective fines on Arab towns and villages, and interned Arabs in camps. ${ }^{368}$ Most shocking, British authorities used Arabs as forced labour for a variety of purposes, and blew up complete towns or villages suspected of giving sanctuary to the guerrillas. Then, in an effort to placate the Arab anger, the British government organized a royal commission to report on the underlying cause of the Arab attitude and the disturbances of $1936 . .^{369}$

Chaired by Lord Peel, the Royal Commission on Palestine found two irreconcilable and entrenched communities that were unwilling to co-operate in any fashion. The commission concluded that the causes of the disturbances were the Arab desire for national independence, and their hatred and fear of the establishment of the Jewish National Home. ${ }^{370}$ The commission also concluded that the Mandate should not

\footnotetext{
368 Abboushi, “The Road to Rebellion,” p. 35.

${ }^{369}$ Peel, "The Report of the Palestine Commission," p. 761.

${ }^{370}$ Esco Foundation, Palestine, p. 820.
} 
continue under the existing terms and limitations. The Balfour Declaration and the Mandate had denied national independence to the Arabs. It was simply impossible to arrive at any solution under the present circumstances. Therefore, Peel proposed that Palestine should be partitioned into two independent states, with Great Britain retaining a permanent Mandate. ${ }^{371}$ As Lord Peel stated in the fall of 1937:

We should get rid at one blow of all ambiguity about the difference between Palestine as a Jewish Home and a Jewish Home in Palestine; all that bundle of controversy and difference would be swept away. There would be no bickering with the Government at Jerusalem, no more wrangling about absorptive capacity, no more sorting out categories of immigrants. The Jews could decide without hindrance on the countries from which they desired to bring immigrants into Palestine; there would be no limit on Jewish immigration except what the Jews themselves thought ought to be applied. . . . The Jews would be able to conduct their own government in their own way. There would be no necessity to make allowances for variations in the different economic and cultural standards of two races. The Arab grievances, the Arab hostilities, the Arab fear of the Jews would be at once turned into other channels. ${ }^{372}$

While the Peel Commission did not provide a detailed scheme of partition, it did propose a scheme whereby Palestine and Transjordan would be re-divided into three regions: a Jewish State, an Arab State, and a British enclave.

Initially, the Peel plan was hailed as a success by the British government. In a White Paper, which accompanied the publication of the Peel report, the British government declared itself "satisfied that the scheme of partition on the general lines recommended by the Royal Commission represented the best and most hopeful solution

\footnotetext{
${ }^{371}$ Elizabeth MacCallum, "Palestine: Postwar Policy and the 1939 White Paper," [n.d.], King Papers, LAC, MG 26, J4, Vol. 310, File 3308, C214533-C214534.

372 Peel, "The Report of the Palestine Commission," p. 772.
} 
to the deadlock." ${ }^{\prime 373}$ However, in less than a year's time, the British government's approval was rescinded in the face of Arab-Jewish opposition. ${ }^{374}$ The idea of partition was wholly unacceptable to the Arabs. ${ }^{375}$ Not only was the Arab leadership unwilling to consider redrafting Palestine's and Transjordan's boundaries, but it doubted whether the Zionists would accept "a Jewish state comprising a smaller or less advantageous area in Palestine" ${ }^{\text {376 }}$ Arab opposition was not just found among Palestinian Arabs, but it was felt throughout the whole region. For example, in a letter to the secretary-general of the League of Nations, the Iraqi prime minister condemned the idea of partition, arguing that the proposed plan was an injustice to the Arab people of that country. The letter further asserted that the hope of a permanent settlement depended upon the recognition of an independent Palestine, in which the Jews accepted finally the position of a minority. ${ }^{377}$ The sentiment of the letter represented the ever-increasing tensions throughout the region and the broad-based animosity towards the Jews.

The Zionists were equally resistant to Peel's partition scheme. At the 20th Zionist Conference held in Zürich, Switzerland, from August 3-17, 1937, the hawkish "Revisionist" party, led by Vladimir Jabotinsky, opposed the idea of partition because it did not yield their ultimate goal of establishing a Jewish state in the whole area of Palestine. Other political factions opposed partition on practical terms, pointing out that a

\footnotetext{
${ }^{373}$ RIIA, Great Britain and Palestine, p. 100.

374 Elizabeth Monroe, Britain's Moment in the Middle East, 1914-1956 (Baltimore: John Hopkins Press, 1963), p. 81.

${ }^{375}$ Sakran, Palestine Dilemma, p. 142.

${ }^{376}$ RIIA, Great Britain and Palestine, p. 102.

${ }^{377}$ Ibid, pp. 104-105.
} 
small state would not be economically viable or militarily defensible. The only supporter of partition was Dr. ChaimWeizmann, who argued that for the first time since the Jewish dispersal, recognition of Jewish statehood had been explicitly accepted. ${ }^{378}$

For the Arab and Jewish communities, Britain's retreat from the Peel recommendations appeared to support the case that, in the face of opposition, the British government would always give way. At the end of September 1938, with the world's gaze squarely focused on developments in Germany, the British government postponed a final decision on the partition of Palestine. To play for time, the British government proposed yet another royal commission, which would "consider in detail the practical possibilities" of the Peel Commission's partition scheme. ${ }^{379}$ The Commission on Partition, better known as the Woodhead Commission, unanimously concluded that partition was impracticable. Published on November 8, 1938, the Woodhead Report stated that partition was irreconcilable with the distribution of Arab and Jewish populations throughout Palestine. Without the use of force, it seemed improbable that the Jewish settlements and Arab populations could be moved en masse. Economic and financial constraints, moreover, prohibited the Arab state, and to a lesser degree the Jewish state, from becoming self-sufficient sovereign states. Therefore, the Woodhead Report concluded that no reasonable prospect existed for the eventual establishment of self-supporting Arab or Jewish states.

\footnotetext{
${ }^{378}$ Ibid, p. 105.

379 John Woodhead, "The Report of the Palestine Partition Commission," International Affairs, Vol. 18, No. 2 (March-April, 1939), p. 171.
} 
On the day the British government released the Woodhead Report, it simultaneously issued a communiqué that affirmed what the Woodhead report had already articulated. ${ }^{380}$ The communiqué further announced the government's intention to hold tripartite meetings in London with Arab and Jewish delegations in the hope of finding a compromise to the Palestine impasse. ${ }^{381}$ Most importantly, it declared, in MacCallum's words, that "if a joint policy could not be worked out within a reasonable length of time the government itself would draw up and put into effect a policy of its own." She also pointed out that the Commission was "willing to support provisional cantonization or the establishment of two separate Mandates." 382

The Jewish Agency immediately rejected the Woodhead findings, declaring their disappointment with its interpretation of the situation. The Agency believed that the true purpose of the Commission's work was to abandon the Jewish National Home, the Palestine Mandate, and the Balfour Declaration. Concerning the proposed meetings in London, the Jewish Agency stated that it would attend only on "the basis of the Mandate and Balfour Declaration." 383 The League of Nations' Permanent Mandates Commission was equally concerned about the Woodhead findings. It advised against the immediate creation of two independent states. The Arab leadership, in contrast, expressed satisfaction with the abandonment of partition, believing that British attitudes were

\footnotetext{
${ }^{380}$ Ibid, p. 11. For details of the British statement, see: Great Britain, Palestine: Statement by His Majesty's Government, Cmd. 5893 (London: Hiss Majesty's Stationary Office, 1938).

381 "The Report of the Partition Commission," Bulletin of International News, Vol. 15, No. 23 (November 19, 1938), p. 8.

382 MacCallum, "Palestine: Postwar Policy."

${ }^{383}$ Woodhead, "The Report of the Partition Commission," p. 12.
} 
finally changing. Consequently, the Arab leadership agreed to attend the London discussions. $^{384}$

By the time the invitations to attend the Round Table Conference in London had been sent out to the Palestinian Arabs, the neighbouring states of Egypt, Iraq, Saudi Arabia, Yemen, Transjordan, and Jewish Agency officials, the British government's thinking regarding Palestine had once again changed. It had been overtaken by events. It was the year "of Munich and the seizure of Austria, of Italian demands for Tunisia, Corsica and Nice, Japan's 'new order in East Asia,' of the slow collapse of the Spanish Republicans under fire from shells made in Germany." 385 The Foreign Office and the British Chiefs of Staff had repeatedly been warning the government that the Palestine question needed to be resolved in a fashion that was satisfactory to the Arabs. It was anticipated that Britain would soon be at war with Germany and Italy, and the Eastern Mediterranean theatre of action would play a pivotal role in Britain's war efforts. For British strategic thinkers, noted historian Bernard Wasserstein, the Middle East was the British Empire's Achilles' heel. ${ }^{386}$ Eastern Mediterranean security was dependent upon good relations with the Arab states in the region. If Arab unrest continued and required ever-increasing policing, it would force Britain to transfer some of its Middle Eastern Reserve Force to Palestine. It would also require the Royal Navy to tie up some of its naval assets in preventing illegal immigration into Palestine. This meant that part of the British land and sea forces designated to defend the Suez Canal would be assigned to

\footnotetext{
${ }^{384}$ Woodhead, "The Report of the Partition Commission," p. 13.

${ }^{385}$ Monroe, Britain's Moment in the Middle East, p. 87.

386 Ibid.
} 
Palestine. This reallocation, concluded British officials, would have a significant impact on the Eastern Mediterranean theatre. Peace in Palestine was essential.

In a candid speech on February 14, 1939, Colonial Secretary Malcolm MacDonald told the Jewish delegation attending the London Conference "that in the event of war, "the security of British forces in the Middle East and the lines of communication with India and the Far East' depended on the maintenance of friendly relations with governments in the region. ${ }^{״ 87}$ MacDonald stressed the importance of the Suez Canal, the British naval base at Alexandria, and British oil interests in Iraq. A "continuation of the estrangement in Palestine" would not only threaten the entire British position in the Middle East, declared MacDonald, but it would produce "a good deal of unrest among the Muslims of India." 388

The London meeting had quickly become two parallel conferences. The Arabs and Jews stated their cases in extreme forms, showing little room for compromise. Since the Arab and Jewish delegations to the Conference were unable to accept the proposals laid out by British officials, Malcolm MacDonald, as promised in the White Paper of 1938, imposed a plan that would see the creation of an independent Palestine State. MacDonald's scheme was embodied in the British White Paper of 1939.

\footnotetext{
387 Bernard Wasserstein, Britain and the Jews of Europe, 1939-1945 (Oxford: Clarendon Press, 1979), p. 17. ${ }^{388}$ Ibid.
} 


\section{The MacDonald White Paper of 1939}

On May 17, 1939, after the tripartite meetings failed to resolve the Palestine impasse, Malcolm MacDonald enunciated the British government's policy on Palestine. The Colonial Office's new decree was a bold and unvarnished statement of Britain's intent regarding the Palestine Mandate. No longer were British intentions shrouded in vague definitions and ambiguous pledges. As Elizabeth Monroe noted, the MacDonald White Paper of 1939 was:

the first official British attempt to come to an honest and definitive decision about reconciling the two halves of the Balfour declaration - the half which gave British blessing to a Jewish national home, and the half that said "it being clearly understood that nothing shall be done which may prejudice the civil and religious rights of existing non-Jewish communities in Palestine." 389

The statement recognized that the new political circumstances in Palestine and Europe required a new praxis, a new approach to Palestine and the Arabs. Accordingly, Britain's policy set out a three-part plan for the renovation of the Mandate that included constitutional, immigration, and land reforms.

In Section 1: "The Constitution," the White Paper unequivocally rejected the Jewish claim that the "framers of the Mandate in which the Balfour declaration was embodied could not have intended that Palestine should be converted into a Jewish State against the will of the Arab population of the country." ${ }^{390}$ With respect to Arab claims to Palestine, the new policy rejected all rights and entitlements promised under the auspices of the McMahon-Husayn agreement. McMahon's pledge was considered by London as

\footnotetext{
389 Monroe, Britain's Moment in the Middle East, p. 88.

${ }^{390}$ Great Britain, "British White Paper on Palestine,” Cmd. 6019 (London: His Majesty’s Stationary Office, 1939), see Section 2: "Immigration." Section 1: "The Constitution."
} 
an inadequate basis for the Arab claims to Palestine. With both Arab and Jewish claims rejected, the White Paper of 1939 proposed the basis for a new independent state in Palestine. In this state, the two peoples of Palestine - Arabs and Jews - would "share authority in a government in such a way that the central interest of each are secured."391 This shared authority, and the establishment of self-governing institutions, would be an evolutionary process that would be instituted over a ten-year period. ${ }^{392}$ During the interregnum, Palestine would remain a mandatory territory administered by Britain, but where both Arabs and Jews could serve as heads of government departments "approximately in proportion to their respective populations."

In Section 2: "Immigration," the White Paper of 1939 tackled the thorny issue of Palestine's future. Britain recognized that the large number of Jewish immigrants who had entered Palestine raised the fear among the Arab majority that this influx would continue indefinitely until the Jewish population outnumbered the Arabs. ${ }^{393}$ This influx gave rise to the "lamentable disturbances of the past three years," declared the White Paper. For that reason, immigration would not be based solely on the economic absorptive capacity of the country, a policy that had governed immigration since Churchill articulated it in 1922. The British government instead proposed that Jewish immigration into Palestine would be allowed to continue for a five-year period until their numbers reached approximately one-third of the total population of the country. The total of immigrants necessary to achieve a one-third status was 75,000 , if economic absorptive

\footnotetext{
391 Wasserstein, Britain and the Jews of Europe, p. 18.

392 "British White Paper on Palestine," Section 2: "Immigration."

393 Ibid.
} 
capacity permitted. After the allotted five years, ending in 1944, further Jewish immigration would be wholly dependent on Arab consent. Concerning the transfer of land, as stipulated in Section 3: "Land," the White Paper prohibited the purchasing of Arab land by Jews in certain areas of the country, and severely restricted it in other areas.

The White Paper of 1939, contrary to the belief of Zionists, was neither a radical nor a revolutionary departure in British thinking; it was the culmination of a decade of deliberations, as expressed in numerous royal commissions and White Papers. It also reflected the changing attitude toward Zionism in Great Britain. For Middle East historian John Marlowe, with the generational change in Britain's political and administrative leadership in the mid-1930s, Zionism had lost most of its influence. "The idealism, sometimes genuine, sometimes more dilettantism, which had seen Zionism as part of a new phase of the European revival and expansion was so much outmoded and so much at odds with the actual state of Western Europe as to seem, not merely ridiculous, but perverse." ${ }^{394}$ The 1939 British policy embodied the view that the Jewish National Home had become a strategic liability to the British government.

The new policy was for the Zionists, declared historian Wasserstein, "a total reversal of the Balfour declaration policy which, notwithstanding some concessions to their views on inessential matters, had been the anchor of British administration of Palestine for the previous two decades." ${ }^{395}$ Zionists around the world were appalled by

\footnotetext{
${ }^{394}$ Marlowe, The Seat of Pilate, p. 158.

395 Wasserstein, Britain and the Jews of Europe, pp. 17-18.
} 
the new British policy, believing Whitehall had cowered in the face of Arab coercion and terrorism - a lesson not lost on Jewish hardliners. In the words of one expert:

World Jewry responded with vehement indignation to what it saw as the subversion of the Jewish national revival in Palestine and the abandonment of European Jewry. Chief Rabbi Isaac Herzog of Palestine wrote to the London Times that the White Paper was "a sin against the spirit of God and the soul of man."396

In the United States, the State Department was inundated with a flood of requests for American official opposition to Britain's new policy. American Jews insisted that the MacDonald White Paper was a violation of the Anglo-American Convention of 1924. The convention, argued Americans Zionists, prohibited the Mandatory power from making any change in the terms of the Mandate without first obtaining the consent of the United States. ${ }^{397}$ By preventing Jews from entering Palestine and purchasing land in the country, claimed American Zionists, the British policy discriminated against Jews and violated the terms of the Mandate. The League of Nations' Permanent Mandates Commission (PMC) was divided over the question of whether the mandatory's policy breached the Mandate. As a result, the PMC decided to delay discussion of the British policy until it had clear instructions from the League's Council. This delay reflected the discord among the PMC's members. ${ }^{398}$

\footnotetext{
${ }^{396}$ Efraim Karsh, Palestine Betrayed (New Haven, Mass.: Yale University Press, 2010), p. 58.

397 Cyrus Adler and Aaron M. Margolith, With Firmness in the Right: American Diplomatic Actions Affecting Jews, 1840-1945 (New York: The American Jewish Committee, 1946), p. 392. For details on the Convention, see: "Convention between the United States of America and Great Britain," December 3, 1924, in Foreign Relations of the United States (FRUS), 1924, Vol. 2 (Washington D. C.: Government Printing Office, 1939), pp. 212-222.

${ }^{398}$ RIIA, Great Britain in Palestine, pp. 126-127.
} 
Shortly after the announcement of MacDonald's policy, Palestine was rocked by violent Jewish demonstrations and proclamations. The Jewish leadership in Palestine declared "the White Paper was a treacherous document which would never be accepted by the Jews." ${ }^{399}$ Sensing a profound shift in British policy, the Arab Higher Committee called the British statement unacceptable, but for different reasons. They objected to the length of the transitional period of ten years as proposed in the White Paper. Pointing to the Franco-Syrian treaty of 1936, the Arab leadership demanded that a Palestinian national government should be instituted at the beginning and not the end of the ten-year transition period. Nor would the Arabs yield in the matters of immigration and land settlement. That should be the prerogative of the national government. They demanded an immediate end to all Jewish immigration and land transfers.

In Canada, the tone surrounding the White Paper was restrained. The Israeli scholar, Zachariah Kay, described the Canadian media coverage of the White Paper as mostly "sympathetic for Zionism and World Jewry." 400 The official Canadian response to the Balfour Declaration and the Palestine Mandate had been circumspect and noncommittal. According to O. D. Skelton, the under-secretary of state for external affairs, the government believed that Palestine was a British problem, and decisions as to its future administration rested firmly with Whitehall. ${ }^{401}$ In a 1939 memorandum to the

\footnotetext{
${ }^{399}$ Esco Foundation, Palestine, p. 909.

400 Zachariah Kay, "The Canadian Press and Palestine: A Survey, 1939-48," International Journal, Vol. 18, No. 3 (Summer, 1963), p. 363.

${ }^{401}$ O. D. Skelton, "Memorandum to the Political Secretary of the New Zionist Organization," June 2, 1937, External Affairs Records, LAC, RG 25, Vol. 1839, Part 1. A. Abraham, the political secretary of the New Zionist Organization, had asked Skelton to support the partition of Palestine as recommended by the 1937 Peel Commission. In response, Skelton restated the view that the Palestine mandate was
} 
prime minister, Skelton repeated his response to Zionist protestations over Britain's policy: "the Canadian Government had not been in any way consulted . . . and I did not imagine the Canadian Government would wish to offer any advice on the matter."402

\section{Emergent Canadian Government Thinking About Palestine}

This lengthy discussion of British policy has been necessary to set the context for a discussion of MacCallum and the emergence of Canadian thinking on Palestine in the war years. The lack of any Middle East specialist in the department had been undoubtedly a limiting factor in the setting out of a Canadian approach to Middle East problems. With no one to study the issue, or offer expert advice, the department was wary about offering an official comment on the Jewish National Home. The government was even more wary about commenting on the 1939 British White Paper. ${ }^{403}$ Canada's absence on the question of Palestine's future also reflected the government's general attitude to the Mandate System as a whole. There is no indication that Canadian officials ever took an interest in any of the "Class A" Mandates - Palestine, Iraq, Transjordan, Syria and Lebanon. The region held very little interest for External Affairs officials or the prime minister.

Britain's responsibility alone. Also, see: Anne Trowell Hillmer, "Canadian Policy on the Partition of Palestine 1947," [Unpublished M.A. Thesis] (Ottawa: Carleton University, 1981), p. 10, footnote 1.

402 O. D. Skelton, "Memorandum for the Prime Minister," May 12, 1939, King Papers, LAC, MG 26, Vol. 199, File: 1865, C138736. Also see: Hume Wrong, "Letter to Cora T. Casselman, M.P.," October 28, 1943, External Affairs Records, LAC, RG 25, Vol. 1839, Part 2; Hume Wrong, "Memorandum for Dr. Gibson," May 8, 1944, King Papers, LAC, MG 26, J4, Vol. 310.

${ }^{403}$ Norman Robertson, "Memorandum for the Prime Minster," October 29, 1942, External Affairs Records, LAC, RG 25, Vol. 1839, Part 2. Robertson warned the prime minister that there was no useful purpose to be served by sending an official Canadian representative to a Zionist conference, since the Zionists were attempting to put the meeting on record as condemning British policy on the Palestine mandate. 
In December 1943, A. J. Freiman, a founding leader of the Zionist Organization of Canada (ZOC), wrote Mackenzie King urging him to clarify his government's stance on the 1939 British White Paper. Freiman argued that the 1939 White Paper was born in an hour of British strategic weakness. It had been denounced by leading British members of Parliament, including Winston Churchill, the colonial secretary at the time of the 1922 White Paper on Palestine, as well as by the Archbishop of Canterbury, who characterized it as "a plain breach of a solemn obligation ... and the destruction of the Balfour Declaration." ${ }^{404}$ Freiman further claimed that the League of Nations' Permanent Mandates Commission had "formally disapproved" of it, and consequently, it had never been submitted to the League's Council. In turning his attention to the purpose of his letter, Freiman stated that the "Canadian government is not without responsibility in this matter and could quite properly, in view of Canada's membership in the League of Nations, make appropriate representations to the British Government . . ."405 Believing that King had a moral and legal obligation to honour the terms of the Mandate and the Balfour Declaration, Freiman solicited the prime minister's support in repudiating MacDonald's Palestine policy.

Freiman's letter was one of a number of efforts made by Canadian Zionists during the war to raise the profile of the issue and press the Canadian government for a response. Since 1941, Zionist groups had tried unsuccessfully to draw King's government into a public debate on Britain's Palestine policy. Their aim was simple: to get the Canadian

\footnotetext{
404 A. J. Freiman, "Letter to Prime Minister Mackenzie King," December 3, 1943, External Affairs Records, LAC, RG 25, Vol. 1839, Part 2, p. 2.

405 Ibid.
} 
government off the sidelines; to convince it to lobby the British to repudiate the 1939 White Paper; and to build popular support among Canadians for a Jewish National Home. Yet Canadian officials remained steadfast in their unwillingness to get drawn into the Palestine question. In the fall of 1943, for example, Samuel Zacks, president of the United Zionist Council, had requested the Canadian Broadcasting Corporation (CBC) for airtime to commemorate the twenty-sixth anniversary of "Balfour Day." Zacks hoped to initiate a public discussion on the Jewish National Home. In response, Saul Rae, a wartime assistant to the under-secretary of state for external affairs, made it clear to CBC officials and Zacks that:

no arrangements have been made by Canadian authorities for marking this anniversary ... While there is no objection on the part of this department to Mr. Zacks' talk on the general subject of Zionism, I think we should avoid any suggestion that this particular programme is associated with any official observance of this anniversary. ${ }^{407}$

Before responding to Freiman's letter, King sought the advice of External Affairs.

He had concluded, perhaps in part because of the growing number of Jewish refugees loosened from war-torn Europe, that the Palestine issue must be reviewed. George Glazebrook, the temporary wartime assistant to the under-secretary, Norman Robertson, asked Elizabeth MacCallum for her comments and a draft response to Freiman's letter. ${ }^{408}$ This provided her with the opportunity to step out from behind the curtain and professionally address the Palestine question. MacCallum's response was divided into

\footnotetext{
406 Peter Aylen, "Letter to Saul Rae," October 2 27, 1943, External Affairs Records, LAC, RG 25, Vol. 1839, Part 2.

${ }^{407}$ Saul Rae, "Letter to Peter Aylen, Program Liaison Officer of the CBC," November 4, 1943, External Affairs Records, LAC, RG 25, Vol. 1839, Part 2.

${ }^{408}$ George Glazebrook, "Memorandum for Mr. Wrong," December 22, 1943, External Affairs Records, LAC, RG 25, Vol. 1839, Part 2.
} 
two parts. First, she offered general comments regarding the British White Paper of 1939 and Canada's obligations as a member of the League of Nations. Second, she drew up a draft letter for the prime minister's response that targeted Freiman's claims.

MacCallum made it clear, first and foremost, that Canada had no legal or moral obligation to the Mandate because of its membership in the League of Nations. The Council of the League of Nations, not its Assembly, had taken the decisions concerning the establishment of the Mandates. With respect to Freiman's allegations that the 1939 White Paper had been denounced by the British Parliament and the League's PMC, MacCallum acknowledged that Churchill had attacked the White Paper, but added that his government, which had been in power since May 1940, "had repeatedly reaffirmed its support" of the 1939 policy. With regard to the PMC, MacCallum declared that four members of the Commission "did not feel able to state that the policy of the White Paper was not in conformity with the Mandate." Although three other members were unable to share this opinion, they considered that the existing circumstances justified the policy of the White Paper, provided that the League Council did not oppose it. Moreover, four of the eleven members of the Commission were not present during the discussion. ${ }^{409}$

As for Canadian policy, MacCallum declared that, "if Canada was to support Zionist aims, it would dismantle the principle of direct consultation." 410 She strongly believed that the Zionists had consistently circumvented direct negotiation with the Arabs, opting instead to allow the British to advance Jewish demands, as the British had

\footnotetext{
409 Elizabeth MacCallum, "Memorandum for Mr. Glazebrook: Mr. Freiman's Letter of December 3, 1943,” December 17, 1943, External Affairs Records, LAC, RG 25, Vol. 1839, Part 2, p. 1. ${ }^{410}$ Ibid, p. 3.
} 
done with the Balfour Declaration and the Palestine Mandate. In her judgement, the Zionist dependence on Britain to push for a pro-Zionist solution did not serve Jewish interests in Palestine. In fact, it had the opposite effect: it jeopardized the Jewish presence in Palestine by alienating the Arabs. ${ }^{411}$ There is little doubt that MacCallum supported the logic of the 1939 White Paper. She viewed it as an attempt to redress the inequalities found in the Mandate. She hoped the MacDonald policy would compel the Jews and Arabs to negotiate a more agreeable and equitable solution.

In concluding her analysis, MacCallum argued that the crux of Freiman's letter resided in its assertion that the "opportunity to live and work" would be denied if Jewish immigration to Palestine were curtailed after March 1944. Implicit in Freiman's statement, said MacCallum, was the belief that the opportunity to live and work was dependent on increasing Jewish population through immigration. It was not the aim of the White Paper, claimed MacCallum, to cut off Jewish immigration into Palestine. Rather, the point of the new British policy was to create a situation whereby an independent Palestinian state could be established and the rights of both Arab and Jewish Palestinians could be equally protected. ${ }^{412}$

In MacCallum's draft letter for the prime minister, she stressed that the intent of the British White Paper was not to close the doors to further Jewish immigration, but instead to create the political conditions that would facilitate the peaceful development of

\footnotetext{
411 Ibid.

412 Ibid, p. 2.
} 
the Jewish National Home through the elimination of perceived Arab threats. She rejected Freiman's idea of repudiating the White Paper, instead cautioning:

To ask for withdrawal of the White Paper now would be for the Canadian government to condemn in advance the effort to establish democratic procedures and the principle that both elements of the Palestinian population must be consulted about policies, which closely affect their interests. $^{413}$

The alternative to the White Paper policy, contended MacCallum, would be for the British government to impose a Jewish state by force of arms upon a non-Jewish society. Not only would this deny the indigenous Arab majority the same right of selfdetermination that the Zionists sought, but it would lead to greater Arab unrest and violence. MacCallum believed that the denial of Arab rights would only result in Jewish refugees having less security in Palestine than they presently enjoyed in Europe. ${ }^{414}$

Following his review of MacCallum's draft letter, Robertson sent a memorandum to the prime minister, in which he reported that the draft response to Freiman's letter had been prepared by Elizabeth MacCallum, who had "expert knowledge of the politics of the Middle East, and although her sympathies rather obviously inclined towards the Arabs, I think her statement of the difficulties of the position is objective and realistic." 415 King authorized Robertson to dispatch the letter, which was sent to Freiman and the Zionist Organization unchanged. ${ }^{416}$ Robertson's comments were precisely correct. While

\footnotetext{
${ }^{413}$ Ibid, p. 5.

414 Ibid.

415 Norman Robertson, "Memorandum for the Prime Minister," December 24, 1943, External Affairs Records, LAC, RG 25, Vol. 1839, Part 2.

416 Mackenzie King, “Letter to Mr. A. J. Freiman,” March 30, 1944, External Affairs Records, LAC, RG 25, Vol. 1839, Part 2, pp. 1-2.
} 
MacCallum was sympathetic to Arab arguments, her memorandum was an objective assessment of the situation. MacCallum's detractors have often cited the Robertson memorandum as evidence of her bias or her limited perspective regarding Palestine. There is, however, a difference between sympathy and prejudice. MacCallum was clearly able to provide External Affairs and the prime minister with a considered commentary on the complicated Arab-Jewish question. It was just as clear that her emerging reputation in the department was making her known to the highest levels of the department, the prime minister's office, and Zionist organizations in Canada.

On the morning of March 31, 1944, a delegation from the Canadian Palestine Committee (CPC) presented Mackenzie King a briefing paper outlining their grievances about the 1939 White Paper. After a short meeting, the prime minister's office sent the CPC brief to External Affairs for a response. The prime minister's office directed the department to undertake at once a comprehensive assessment of the 1939 White Paper, since the prime minister expected that the issue would be raised shortly in Parliament. ${ }^{417}$ The job of drafting the response once again fell to MacCallum. ${ }^{418}$ She eagerly accepted the new assignment, since it gave her an opportunity to provide the department and the prime minister with a more expansive understanding of the historical, economic, and political dimensions of the Palestine problem — an approach, in her judgement, that had been lost in much of the flurry of rhetoric concerning the issue. MacCallum believed that

\footnotetext{
${ }^{417}$ J. W. Pickersgill, "Memorandum for the Under-Secretary of State for External Affairs," April 7, 1944, External Affairs Records, LAC, RG 25, Vol. 1839, Part 2.

418 David Bercuson, Canada and the Birth of Israel: A Study in Canadian Foreign Policy (Toronto: University of Toronto Press, 1985), p. 23.
} 
the debate surrounding the issue had been shaped, distorted, and dominated by the Zionist movement in Canada and beyond. ${ }^{419}$

It is most unfortunate that a case as urgent and just as that of the political Zionists should be made to depend so frequently on assertions no reputable historian would regard as adequate. It is true that there is little knowledge on this continent of what has actually happened in the Near and Middle East in the past 50 years, and that it is consequently easy to manipulate the record so as to encourage the view that Arab claims in the present controversy may be dismissed as all but irrelevant. It is obvious, however, to many who have followed developments attentively that a just decision would have been much easier to arrive at today had the literature of the controversy been less imaginative. ${ }^{420}$

MacCallum was concerned with ensuring that any approach Canadian officials considered was not based on an "either-or" interpretation, but rather rooted in a clear and broad understanding of the facts.

MacCallum's seventeen-page memorandum, "Palestine: Postwar Policy and the 1939 White Paper," was the most comphensive departmental document ever to examine and question Britain's Middle East policy, and its impact on Canadian domestic affairs. ${ }^{421}$ She was tasked with two objectives: to provide an overview of the British White Paper of 1939, and to present a detailed analysis of the arguments advanced by the Canadian Palestine Committee's briefing paper. To meet these requirements, MacCallum used a five-pronged approach: a brief assessment of the factors that contributed to the promulgation of the 1939 British White Paper; an analysis of the substance and implication of the White Paper's provisions; an overview of the responses to the paper

\footnotetext{
419 Elizabeth MacCallum, "Palestine: Postwar Policy," C214545.

${ }^{420}$ Ibid, C214544.

${ }^{421}$ Bercuson, Canada and the Birth of Israel, p. 26.
} 
from Zionists, Arabs, Canadians, and the League of Nations; a detailed response to the Canadian Palestine Commission's allegations about the White Paper; and an outline of Canada's responsibilities with respect to the Jewish National Home and the Palestine Mandate.

In her analysis of the circumstances surrounding the White Paper, MacCallum showed that by 1936 British officials had recognized that Britain's Palestine policy had failed to achieve its intended results. Far from achieving a co-operative relationship, the Mandate had bred suspicion, antagonism, and violence between the two competing populations. By 1938, Whitehall had conceded that it needed to take a fresh approach to settling the long-standing Arab-Jewish stalemate. Indeed, Malcolm MacDonald, the colonial secretary, cabinet, and the prime minister concluded that it was time to end the Mandate. ${ }^{422}$ The colonial secretary believed that the recommendations of the 1937 Peel Commission and the 1938 Woodhead Commission provided the roadmap for a muchneeded change in their policy approach. Throughout the seventeen-year process of the Mandate, British officials had hoped that the Arabs and Jews could put their own houses in order. The British dream of a united Palestine was consistently dashed by extremist attitudes emanating from the two sides. According to MacCallum, Britain believed it had little choice but to impose a settlement on both parties. Thus, following the failed tripartite conference, MacDonald and the Foreign and Colonial Offices decided to draft their own plan and published it as the White Paper on May 17, 1939.

\footnotetext{
${ }^{422}$ MacCallum, "Palestine: Postwar Policy,” C214534.
} 
MacCallum repeated the uncontested view that the ambiguities, complexities, and contradictions of the Balfour Declaration and the Palestine Mandate were the root causes of the wholesale unrest and Arab violence. ${ }^{423}$ The Mandate's unclear definitions and functions, stated MacCallum, were the direct result of the British government's attempt to advance their own strategic interests. For MacCallum, Britain's policy of stewardship and development of the region was nothing more than a cover for their imperial ambitions in the region, which had led to a contradictory and inconsistent set of policies, as reflected in the Balfour Declaration of 1917, the Palestine Mandate of 1920, and the British White Paper of 1922.

In her assessment of the White Paper's context, MacCallum identified Britain's intent to maintain a long-term presence in Palestine. By dismissing the McMahonHusayn agreement as invalid, and the Zionist claims that the Balfour Declaration and the Palestine Mandate were intended as instruments for transforming Palestine into an independent Jewish State, ${ }^{424}$ it appeared to her that London was preparing Palestinians for a binational state, where Britain would indeterminately hold the reins of power. While MacCallum disagreed with the logic and substance of British thinking, she supported the establishment of an independent binational state. Yet, in her judgment, this would be difficult to achieve if it was imposed by the threat of force. In any future independent

423 Ibid., p. 2. Also see: Arnold Toynbee and Frank T. Ashton-Gwatkin (eds.), Survey of International Affairs, 1939-1946: The World In March, 1939 (London: Oxford University Press, 1952), p. 137. Toynbee and Ashton-Gwatkin asserted that on four occasions between 1920 and 1933, violent attacks occurred on Jewish settlers by Arabs, who refused to accept the Balfour Declaration as the basis of the Mandate. Many Arabs were angered by being precluded from having any influence on the immigration policy of the Mandatory Power.

${ }^{424}$ MacCallum, "Palestine: Postwar Policy,” C214542. 
Palestinian state, suggested MacCallum, Arabs and Jews would have to work out a relationship by "sharing authority in such a way that the essential interests of both would be secured." ${ }^{425}$ She believed that a binational plan was achievable by the gradual integration of both Arabs and Jews into the state apparatus until they were in charge of departments of government, assisted by British advisers. These appointments, said MacCallum, would occur over a period of ten years, and would reflect Palestine's population. ${ }^{426}$ The implications of this proposal were unmistakeable to MacCallum; with a clear majority of the population, the Arabs would eventually control the state's key administrative posts, and thereby, the government apparatus. Consequently, the Jewish National Home would be put under Arab control — a situation she knew the Zionists would never accept. It would mean war.

The most crucial portion of the White Paper, and certainly the most contentious in MacCallum's judgment, was the revision of Palestine's long-standing immigration policy. According to the British plan, London had decided to end the long-standing policy of "Economic Absorptive Capacity" (EAC), which had been the guiding principle of the Jewish Agency's immigration policy since $1920^{427}$ and had afforded the Zionists a framework for building up a Jewish majority in Palestine. ${ }^{428}$ In its place, the British government introduced an immigration mechanism that reflected the economic and social

\footnotetext{
425 Ibid, C214535.

${ }^{426}$ Ibid.

${ }^{427}$ MacCallum, "Palestine: Postwar Policy,” C214536. For a discussion of EAC, see: M. Mossek, Palestine Immigration Policy under Sir Herbert Samuel: British, Zionist and Arab Attitudes (London: Frank Cass and Company Ltd., 1978), p. 59.

${ }^{428}$ Mossek, Palestine Immigration Policy under Sir Herbert Samuel, p. 59.
} 
conditions of all Palestinians, not just the Jewish community. The abolishment of the EAC, however, was anathema to the Zionists.

As a writer on Palestinian affairs and the Mandates System, MacCallum had appreciated how effective the EAC had been. It had not only been successful in justifying the constant increases in Jewish immigration quotas, but it had refuted all those critics who opposed the steady entry of Jews into Palestine. Yet British officials could ill afford to continue a policy that so angered and alienated the Arab population. Arguing that the EAC had met the objectives of establishing and ensuring the continued existence of the Jewish National Home in Palestine, British officials believed the time had come to develop an alternative immigration plan for Palestine's long-term development. They were confronted with two available options: either London could continue its present course of expanding the Jewish National Home indefinitely by immigration, against the strongly expressed will of the Arab inhabitants, or the British could permit immigration only through a compromise agreement with the Arabs. ${ }^{429}$

Given the Arab animosity, MacCallum believed that the second option was the only practical solution for the British. To carry the first option to its logical conclusion meant helping the Jews to acquire a majority population, and thereby, facilitating the creation of a Jewish state in Palestine. The first option also undoubtedly meant violating the spirit of the Palestine Mandate. ${ }^{430}$ MacCallum referred to Article 6 of the Mandate, which ensured that "the rights and position of other sections of the population are not

\footnotetext{
${ }^{429}$ MacCallum, “Palestine: Postwar Policy,” C214536.

${ }^{430}$ Ibid.
} 
prejudiced." Article 11 provided similar pledges: "The Administration of Palestine shall take all necessary measures to safeguard the interests of the community in connection with the development of the country." MacCallum believed unrestricted immigration endangered employment opportunities for Arab farmers, as well as undermining the safety and well-being of the community as a whole. Moreover, in MacCallum's judgment, unrestricted immigration could only be maintained by force.

Since the League's adoption of the Mandate in 1922, MacCallum had seen a link between Arab violence and unrestricted Jewish immigration practices. The 1936 rebellion was proof enough of that belief. There was no doubt in her mind that the Arabs would violently resist any approach that encouraged Jewish immigration against the will of the majority population. She also knew that the use of force had proven to be an ineffective counter-measure to Arab unrest, since it required an ever-increasing military contingent to maintain peace and order. Against a determined Arab opposition — inside and outside of Palestine - this option would only lead to greater violence, and quite possibly, involve all the Arab countries against the Jews. This was a danger MacCallum believed the British officials could ill-afford to risk, and it was not a policy that Canada should support.

But the second immigration option also posed serious threats to British policy makers. By basing Jewish immigration on Arab consent, it was very likely that a considerable political and military Jewish resistance would emerge in Palestine. However, the British believed that this was less risky than unleashing the anger of the Arab and Moslem Worlds. Yet, as MacCallum noted, it was unlikely the Arabs would 
accept Britain's second's option. To do so, meant an implicit acceptance of the Balfour Declaration, the recognition of the Jewish National Home, and special Jewish rights. It would be political suicide for any Arab leader to support such a policy. With the policy's announcement, many Arab scholars and activists questioned what would happen when the quota of 75,000 was reached. Would Zionists demand more territory or concessions? Would they attempt to seize territory by force? The Zionists had made it clear that they would arm themselves and contest any outcome that did not transform Palestine into a Jewish state. It was apparent to the Arabs that the Zionists would not willingly accept a permanent minority status in Palestine. ${ }^{431}$

Reporting on the final section of the White Paper, MacCallum outlined Britain's proposed policy on land transfers. According to the White Paper, the British high commissioner to Palestine would be empowered to restrict and regulate the transfer of Arab lands to Jewish individuals or holding companies. Purchases of Arab lands by Jews were to be prohibited in some areas, and restricted in other areas. In MacCallum's opinion, the policy had failed to explain in detail how the high commissioner would manage this process. What geographic areas were to be prohibited and which were to be restricted? Was there to be a specific calculus for determining which lands would be transferred? Would the transfers be permanent or temporary? Would the high commissioner's calculus be based on ethnic, religious, or economic considerations?

\footnotetext{
${ }^{431}$ Ibid.
} 
In assessing the MacDonald White Paper, it was evident to MacCallum that the underlying thrust of Britain's policy was to buy London time by appeasing the Arab World. This meant freeing up British forces dedicated to policing Palestine. Britain would neither partition Palestine, nor establish independent Jewish or Arab states. George Kirk, the Middle East archaeologist and commentator, underlined this point when he stated that "the Zionists, however infuriated, could obviously be relied on not to make common cause with their Nazi persecutors, whereas the hostility of the Arab world ... presented immediately a formidable threat to the vital British position in the Middle East." ${ }^{432}$ The British knew that the Arabs were the key to keeping the peace in the region. The White Paper offered the Arabs an independent Palestine state within ten years if they kept the peace. Not to do so meant alienating the moderate Arab nationalists and jeopardizing the security of Britain's Middle East Empire. Thus, the White Paper was well defined in its intent, and striking in its boldness. The British were prepared, or so they claimed, to create and recognize an independent Arab Palestinian state.

In the second part of her memorandum, MacCallum surveyed the various responses, at home and abroad, to the MacDonald White Paper. While she acknowledged the seriousness of the Arab objections to the policy, ${ }^{433}$ she primarily focused her analysis

\footnotetext{
432 Toynbee and Ashton-Gwatkin, The World In March, 1939, p. 138.

433 MacCallum, "Palestine: Postwar Policy," C214537. MacCallum stated that the Arabs also rejected the White Paper because it still involved the recognition of the Jewish National Home. They believed the Balfour Declaration was in conflict with Article 22 of the League Covenant, which stated: "The wishes of these communities must be a principal consideration in the selection of the Mandatory." They also argued that it violated Article 20, which stated that the Covenant "is accepted as abrogating all obligations or understandings inter se, which are inconsistent with the terms thereof, and solemnly
} 
on the Zionist objections, and the reaction of Canadian Zionists in particular. In her judgment, the Zionists' central concern was achieving statehood. In May 1939, reported MacCallum, acting on a cabled request from Zionist Headquarters in London, the president of the Zionist Organization of Canada "protested to the Canadian Government . . against a policy which would limit the Jews forever to one-third of the population of Palestine, close parts of the country to Jewish settlement altogether, and give the territory independence, which meant the establishment of an Arab government. ${ }^{434}$ As far as MacCallum was concerned, this petition was part of a well-co-ordinated effort by the international Zionist movement to reverse the British policy.

It was an all-to-familiar strategy to MacCallum. The Zionist Organization of Canada (ZOC), in association with other foreign pro-Zionist groups, were attempting to persuade the Canadian government to repudiate a British policy. ${ }^{435}$ MacCallum was firmly convinced that the Zionists and Jewish activists would do everything in their power to prevent the implementation of the British White Paper policy. ${ }^{436}$ They were particularly determined to bring to an end Britain's proposed immigration and land reforms. Overt international pressure on the British government had been successful in

undertake that they will not hereafter enter into any engagements inconsistent with the terms thereof."

${ }^{434}$ Ibid, C214540.

435 Mackenzie King, "Secretary of State for External Affairs to Dominions Secretary,” May 15, 1939, in Documents on Canadian External Relations (DCER), Vol. 6, 1936-1939 (Ottawa: Government of Canada, 1972), p. 872. For example, on May 15, 1939, the Zionist Organization of Canada asked the department to transmit a note to the Dominions Secretary, which stated: "'the hope that in the approaching Palestine settlement no policy will be adopted which will make impossible a definitely substantial and continuing flow of immigration of Jews from the various troubled areas of the world or the building up a Jewish National Home in accord with what they consider the commitments given twenty years ago."”

436 Ibid. 
the past, and there was no reason to believe that Britain was any more committed to MacDonald's plan than they had been to the Peel or Simpson reports.

In assessing the Zionist response, MacCallum turned her attention to the specific claims made by the CPC regarding Canada's legal and moral obligations to the Palestine Mandate. By challenging the substance and veracity of Zionist allegations, she hoped to place Canada's tentative Palestine policy in a less defensive posture. First, she refuted the claim that Canada, as one of the "52 nations signatory to the measure by which the Mandate was conferred on the United Kingdom government," was responsible to uphold the terms of the Mandate. ${ }^{437}$ MacCallum explained that the "Mandates were not allocated in a manner conforming to the spirit of Article 22 of the Covenant, and precautions were taken by the League Council to prevent the Assembly . . . from discussing officially the terms of the Mandate, whose acceptance the Council kept in its own hands." MacCallum further argued that Charles J. Doherty, Canada's representative to the League in $1920,{ }^{439}$ had protested vigorously against the League's lack of consultation in allocating Mandates, and particularly against the Council's refusal to allow the Assembly to study the Mandates. Therefore, any interest Canada may have had in the White Paper derived not from the League's authority, insisted MacCallum, but "from its membership

\footnotetext{
${ }^{437}$ MacCallum, "Palestine: Postwar Policy,” C214541

438 Ibid, C214542. MacCallum is referring to the San Remo Conference held in April 1920, which confirmed the pledge contained in the Balfour Declaration concerning the establishment of a Jewish National Home in Palestine.

439 "List of Principal Persons," in DCER, Vol. 2, The Paris Peace Conference of 1919 (Ottawa: Department of External Affairs, 1969), p. xii. Charles Doherty was Minister of Justice, 1911-1921, and Plenipotentiary of Canada at the Paris Peace Conference.
} 
in the United Nations and the responsibility it will share for establishing a just and durable peace." $" 440$

The second charge that MacCallum tackled was the Zionist allegation that the Balfour Declaration was issued by the British as the prospective conqueror of the Ottoman Empire. More precisely, the Zionists claimed that the Arabs may have expected a sovereign Arab State, which included Palestine, based on majority occupancy after the First World War, but that they were incorrect to do so. MacCallum countered this assertion by stating that the right of conquest "was not the sense in which the Mandate system was generally understood." ${ }^{\prime 41}$ The Canadian delegation explicitly rejected this viewpoint in 1920. The position taken by Doherty during the League's deliberations was sufficient evidence that the Canadian Government did not, implicitly or explicitly, accept or recognize the British Palestine Mandate as a right of conquest. ${ }^{442}$

The Zionists' brief further insisted that the American and British governments intended the Balfour Declaration to be the first step in the establishment of a Jewish state. ${ }^{443}$ MacCallum responded that, while the British and American governments may have wished to have an independent Jewish State emerge from the colonization of Palestine, the vagueness of the Balfour Declaration and the Palestine Mandate reflected the fact that there was not a universal consensus on the matter. The form that the

${ }^{440}$ MacCallum, "Palestine: Postwar Policy," C214542. The United Nations was the name given to the alliance of Second World War Allies.

${ }^{441}$ MacCallum, "Palestine: Postwar Policy," C214542.

${ }^{442}$ Ibid.

${ }^{443}$ Government of Britain, “The British White Paper of 1939," Section 1. This claim had already been struck down by the British, who asserted that it was never the intention of its framers of the Balfour Declaration or the Mandate to transform Palestine into a Jewish state. 
declaration took, said MacCallum, was evidence that a compromise was needed to bridge the differences among the interested parties. This was particularly evident in the decision to include provisions that secured the rights of both Arabs and non-Zionist Jews.

In responding to the $\mathrm{CPC}$ charges that the MacDonald White Paper violated the Balfour Declaration's pledge to deliver the Jews from a great wrong — "the relegation of Jews to a perpetual minority status in every country where they were permitted to live" — MacCallum declared that this belief was based on the "popular illusion that the Jewish dispersion was forced." ${ }^{\prime 44}$ On the contrary, argued MacCallum, by the time the Romans conquered Palestine, most Jews had voluntarily left Palestine in search of a better life. While MacCallum regretted the discrimination and persecution that the Jews had experienced in Europe, she rejected the Zionist argument that there was moral equivalency between persecution and minority status, "since the Balfour Declaration itself makes reservations on behalf of those Jews who preferred minority status in the Diaspora to the prospect of majority status in Palestine." 445

On the Zionist assertion that the White Paper was "an offspring of the pre-war policy of appeasement, now fully discredited," MacCallum disparaged the charge as Britain's constant companion, which habitually followed it no matter what its policy. In her most passionate critique, MacCallum attacked the Zionist argument that Britain's White Paper reflected the British government's capitulation to Arab threats and violence and thus "To satisfy any Arab demand whatsoever will be to "yield to a truculent people

\footnotetext{
${ }^{444}$ Ibid, C214543.

${ }^{445}$ Ibid.
} 
who have resorted to arms." Seeing hypocrisy in the statement, she remarked that in 1939 Zionist leaders had themselves threatened to resort to violence to prevent the White Paper from going into effect. ${ }^{446}$ "They were willing to fight in order to win the majority status, which Arabs had already been fighting to keep. The secret arming of Jews in Palestine is held to be not unconnected with the threats heard in 1939." ${ }^{\prime 47}$ Abandoning her normally sober analysis, MacCallum forcefully declared that the "worldwide clamour, insistently brought to the attention of every western nation by its Jewish citizens," was worse than the apparent appeasement of Arabs. Like the Munich Agreement, MacCallum warned, the Balfour Declaration was done without consulting those in possession of the region concerned. It was wrong that a territory could be transferred into the hands of an ambitious people who were able to put forward a claim of historic association.

Concluding her critique of the CPC brief, MacCallum examined the consequences of closing Palestine to Jewish immigration. The CPC brief suggested that Jewish refugees would want to come to Canada as Canadian officials attempted "to cope with the rehabilitation of almost a million demobilized service men and women." She noted drily that this was "not the first time it has been suggested to Canadians that it would be to their advantage to support unrestricted immigration into Palestine in order to reduce the number of applicants for admission to this country." Non-Zionist Jews in Canada considered "such an approach to be treasonous both towards European Jews and toward

\footnotetext{
${ }^{446}$ Ibid.

${ }^{447}$ Ibid.
} 
themselves." ${ }^{448}$ This tactic, insisted MacCallum, reflected just how far the Zionists would go to "establish quickly the desired numerical majority in Palestine even if it should increase the sufferings of those who have survived the terror in Europe." It also suggested discrimination against non-Zionist Jews wanting to enter Canada, which in turn, argued MacCallum, would "adversely affect the status of the Jewish citizens in Canada." 449

Regarding the White Paper's impact on Canadian policy, MacCallum made no specific or explicit recommendations. She believed it was not her place to do so, since that was the role and responsibility of her superiors. However, she did formulate some observations or, as she described them, "considerations," that she felt the government needed to think through. First and foremost, she believed that an unjust Palestine settlement would affect "the stability of postwar arrangements as a whole." ${ }^{450}$ If Zionists were denied statehood in Palestine, it would have consequences for international harmony everywhere. On the other hand, if Arab Palestinians became the minority within a Jewish state, it could unleash forces in the whole region hurling the Great Powers and the Middle East into war. Furthermore, she stressed the difficulty in negotiating a settlement, since neither Arab nor Jew would contemplate any outcome that assured them anything less than total independence. In principle, claimed MacCallum, the partition proposal would not satisfy the Zionist movement or the Arabs. The Jews, on the one hand, believed that the portion of Palestine offered to them in the White Paper was too small and utterly inadequate for the purpose of statehood. The Arabs, on the other hand,

\footnotetext{
${ }^{448}$ Ibid, C214544.

${ }^{449}$ Ibid.

${ }^{450}$ Ibid.
} 
found the British policy unacceptable since it would give the Jews a foothold in Palestine and only serve to "drive the Jewish wedge more firmly than ever into a strategically important part of the Arab heritage." 451

No matter the outcome, warned MacCallum, Canada would come under intense international pressure to take an active role in ensuring a peaceful and equitable outcome. "Insofar as Canada is recognized as a leader among smaller powers it will be expected to watch with sympathy — and to aid when it can properly do so — the efforts to achieve nationhood and political independence of such peoples as the Arabs and the Jews." ${ }^{\prime 452}$ MacCallum speculated that Canada would also be expected to defend the interests of Jews, who continued making their homes in Europe and North America. ${ }^{453}$ Given the fact that neither the Arabs nor the Jews would accept partition or negotiate a compromise, MacCallum suggested that Canada should adopt, and encourage other nations to adopt, a more liberal policy toward Jewish immigration. In doing so, she believed, Canada could lessen the pressure on Palestine to accept Jewish refugees flooding out of Europe.

Domestically, MacCallum warned the government that it needed to be conscious of the struggle taking place at home between Zionists and Arabs. These clashes would make it necessary to weigh carefully any proposed action that Canada was asked to support. Even with a full knowledge of Palestine's history and each community's claims, opined MacCallum, just decisions would be difficult, if not impossible, to make. An

\footnotetext{
${ }^{451}$ Ibid, C214548

452 Ibid, C214545.

${ }^{453}$ Ibid.
} 
uneven playing field presently existed, claimed MacCallum, where only one side was "organized and equipped to carry on active propaganda in Canada, and when newspapers, radio broadcasts and public lectures serve to disseminate" the views of only one of the contesting parties. MacCallum cautioned that the government would come under increasing pressure from Zionist organizations seeking to force the prime minister's hand. While Canada's involvement in the struggle for Palestine seemed unavoidable, she recommended that the government should remain at arm's length from the situation. Failure to do so could lead Canada to being drawn into the Arab-Jewish maelstrom.

MacCallum's memorandum quickly found supporters within the department, and in the prime minister's office. Among her strongest supporters were George Glazebrook and Hume Wrong. In a note to Wrong, the associate under-secretary of state for external affairs, Glazebrook remarked, "this is a valuable paper that will form a source of information ... wherever the question comes up."454 A week later, Wrong wrote Dr. James Gibson of the prime minister's office and stated that he thought MacCallum had made a detailed study of the arguments advanced by the Canadian Palestine Committee, in the course of which she had explained the Arab point of view. Wrong found MacCallum's study an important contribution to the Palestine question, particularly in the study's strategic assessment of the potential dangers to international peace and security. He further suggested that "it might be useful to have on the files at Laurier House," the

\footnotetext{
${ }^{454}$ George Glazebrook, "Memorandum for Hume Wrong," May 1, 1944, External Affairs Records, LAC, RG 25, Vol. 1839, Part 2, p. 1.
} 
prime minister's home. ${ }^{455}$ The memorandum indeed, had already been taken to London for use by the prime minister at the Commonwealth Prime Minister's Conference.

Glazebrook and Wrong appeared to have come to the same conclusion as she had — Canada should be careful in taking a position on Palestine. Glazebrook warned that it was Britain's affair and Canada needed to be cautious in its support for the Arab or the Jewish position. ${ }^{456}$ "No matter what may be done about the White Paper, Palestine will remain, for a long time, a troubled area in a region of the world in which it is most unlikely that Canada will have any very direct interest," advised Wrong. ${ }^{457}$ However, not all of the department's officers agreed with MacCallum's assessments or indeed her conclusions. Dr. Paul-Emile Renaud, a foreign service officer, disputed the premise of MacCallum's study. In a June 10, 1944 memorandum to MacCallum, Renaud, who had a doctorate in law, ${ }^{458}$ challenged her claim that the "Canadian Government had nothing to do' with the ratification by the Council of the League of Nations of the Mandate for Palestine." 459 Renaud argued that Canada, in ratifying the Treaty of Versailles, implicitly ratified Section 8 of Article 22 of the League of Nations' Covenant. ${ }^{460}$ "The legal effect

\footnotetext{
455 Hume Wrong, "Memorandum for Dr. Gibson,” May 8, 1944, King Papers, LAC, MG 26, J4, Vol. 310, p. 1.

${ }^{456}$ George Glazebrook, "Memorandum for Hume Wrong,” p. 2.

${ }^{457}$ Ibid, p. 2.

458 John Hilliker, Canada's Department of External Affairs: Vol. 1, The Early Years, 1909-1946 (Montreal \& Kingston: McGill-Queen's University Press, 1990), p. 121.

459 Paul-Emile Renaud, "Note for Miss MacCallum, Re: Canada and the Mandate for Palestine," June 20, 1944, External Affairs Records, LAC, RG 25, Vol. 1839, Part 2, p.1.

${ }^{460}$ League of Nations Covenant, Section 8, Article 22.
} 
of this provision," asserted Renaud, "was to confer upon the Council the power to ratify the terms of the Mandate for Palestine." 461

Rarely shying away from a debate on Palestine, MacCallum countered that the Council of the League of Nations had prevented the Assembly from officially discussing the terms of the Mandates. ${ }^{462}$ Consequently, the Council alone approved the Mandate's acceptance. ${ }^{463}$ She further argued that, at the time of the Chanak incident of 1922 , Mackenzie King had suggested to Arthur Meighen, the Opposition leader, that "Canada was not bound by anything in the Treaty of Sèvres, owing to the repudiation of the document by the Turkish government and its non-ratification by the United Kingdom government."464 Therefore, insisted MacCallum, this could not be the "act of endorsement to which Zionist communications habitually refer." 465

While isolated departmental disagreements continued over Canada's commitment to the Balfour Declaration and the British Mandate in Palestine, MacCallum's study was generally accepted by the department's senior officers. In fact, it was considered a valuable political tool in the government's efforts to neutralize the Zionist campaign and distance itself from the Palestine problem. On April 20, 1944, the prime minister rose in the House of Commons and gave Canada's response to the British White Paper of 1939.

\footnotetext{
461 Ibid.

462 Elizabeth MacCallum, "Memorandum for Mr. Renaud,” [n.d.], External Affairs Records, LAC, RG 25, Vol. 1839, Part 2, p. 1. The Treaty of Sèvres stripped Turkey of the Arab and North African provinces.

463 MacCallum, "Palestine: Postwar Policy," C214541. Also, see: Elizabeth MacCallum, "The Turco-Iraq Boundary Dispute," FPAIS, Series 1925-1926, No. 3 (November 5, 1925), p. 2.

464 Elizabeth MacCallum, "Memorandum for Mr. Renaud," [n.d], External Affairs Records, LAC, RG 25, Vol. 1839, Part 2, p. 1.

465 Ibid.
} 
King insisted that whether or not Palestine became a single or partitioned state largely depended on British efforts and goodwill. "[T]he British, long the friends of the Arabs and for centuries the most just and humane in their treatment of the Jews, will do their utmost in a sincere endeavour to reach the best settlement possible." ${ }^{466}$ The prime minister also made it clear to the Zionists that the Canadian government's position was to allow the British to resolve the issue.

Yet Palestine was not MacCallum's sole concern during this period. In late 1944 and early 1945, as the Department of External Affairs looked beyond the Allied Powers' victory over the Axis Powers, MacCallum's skills were summoned to take on broader topics of postwar international security arrangements. ${ }^{467}$ In March 1945, she was charged by the under-secretary to prepare an overview of the February 12, 1945, official communiqué of the Crimea Conference for the prime minister. ${ }^{468}$ In response, MacCallum prepared a 13-page summary of the Conference, along with a credible assessment of the dangers associated with the postwar international system. The document mirrored many of concerns expressed by the prime minister. She clearly spelled out the practical challenges that the postwar period would pose for the Canadian government in dealing with the growing differences among the Great Powers, and with the dominant role that the United States and the Soviet Union would play in shaping the postwar international landscape.

\footnotetext{
${ }^{466}$ R. G. Riddell and Saul Rae, "The British White Paper on Palestine," [n.d.], King Papers, LAC, MG 26, J4, Vol. 310, p. 2.

467 J. W. Pickersgill and D. F. Forster (eds.), The Mackenzie King Record: Vol. 4, 1947-1948 (Toronto: University of Toronto Press, 1970), p. 27.

${ }^{468}$ Elizabeth MacCallum, “The Crimea Conference,” March 1945, King Papers, LAC, MG 26, J4, Vol. 310.
} 


\section{Conclusion}

For Elizabeth MacCallum, the war was a period of intense professional transformation. Her career with the department began in relative obscurity; however, her position was quickly transformed by the worsening conditions in Palestine, and the pressure on the King government to take a stand on the issue. By early 1943, Norman Robertson, the under-secretary of state for external affairs, had formally acknowledged her work and abilities. She became a person to whom the department could turn on matters concerning Middle East affairs. She was also recognized for her knowledge of the Mandate and Trusteeship system.

Consistent in all of her efforts was a firm grasp of the issues. In the case of Palestine and the British White Paper of 1939, MacCallum knew that the MacDonald policy was not just an act of pre-war appeasement, but that it reflected the culmination of a decade of British thinking regarding their place in the Middle East. After years of research and analysis, she recognized that Palestine was the epicenter of the Arab nationalist movement, and a catalyst for anti-Western sentiment. In the face of Arab and Jewish threats and lobbying efforts in Palestine and beyond, MacCallum did not doubt that the Palestine crisis had the potential of becoming a spark for international conflict and Great Power differences.

While MacCallum had sympathy for the Palestinian Arabs' position, her approach remained well considered, and professional - even if it sometimes ran contrary to the accepted wisdom held in the department. She demonstrated little fear in taking on contentious positions. Equally valuable, on a pragmatic level, MacCallum's work 
reflected an appreciation of the government's domestic priorities and the prime minister's sensibilities; she anticipated King's concerns about Canada's engagement in contentious international issues and the manner in which international problems could become domestic ones. Her major Palestine memorandum was sufficiently powerful that it became the sole briefing note on the Palestine question for Canadian delegates to the United Nations Conference on International Organization. ${ }^{469}$ Her voice was beginning to be heard.

469 “Memorandum for Delegates and Advisors," External Affairs Records, LAC, RG 25, Vol. 1027, p.2. 


\section{Chapter 4 San Francisco: MacCallum and Canada at the Margins, 1945}

With the winding down of the Second World War, MacCallum's thoughts turned to the postwar period and her future with the Department of External Affairs (DEA). Her principal motivation in joining the department no longer seemed as compelling; the war was almost over, and as a result, the department's staff shortages would soon be remedied by the influx of returning male veterans. ${ }^{470}$ Non-critical personnel, such as the undersecretary's special wartime assistants and wartime clerks, had already begun to leave the department and return to their civilian lives. ${ }^{471}$ Before long External Affairs, and much of the government's bureaucracy, would return to business-as-usual, with men as the mainstay of the workforce. The diplomatic branch of External Affairs would similarly remain a male province, off limits to MacCallum.

However, not all the department's doors were closed to MacCallum. The department would need to increase its personnel to meet its expanded postwar responsibilities. Not only would experienced staff be encouraged to remain in their present positions, but new positions would be structured around the skills of exceptional candidates in order to increase the department's reach and depth. As the department

\footnotetext{
${ }^{470}$ John Hilliker, Canada's Department of External Affairs: Vol. 1, The Early Years, 1909-1946 (Montreal \& Kingston: McGill-Queen's University Press, 1990), p. 279. In January 1944, the department began a three-year program for the recruitment of Foreign Service Officers. The positions were advertised to all ranks overseas, and to prisoners-of-war who had been Canadian residents at the time of their enlistment. Examination boards in Europe conducted interviews at Canada House beginning in August 1944.

471 Gilles Lalande, "The Department of External Affairs and Biculturalism," Studies of the Royal Commission on Bilingualism and Biculturalism, Vol. 3 (Ottawa: Government of Canada, 1969), p. 11.
} 
moved towards a more expanded role in international affairs, it would require the employment of specialized personnel. ${ }^{472}$ Perhaps there would be a role for MacCallum.

Or MacCallum could leave External Affairs and return to New York, where she could further her work as a Middle East analyst for the Foreign Policy Association. There was also the possibility of employment at the U. S. State Department, which was interested in acquiring experts who had a comprehensive understanding of the Middle East. MacCallum, however, wanted to stay in Canada and work for External Affairs. The prospect of serving the Canadian delegation at the upcoming United Nations Conference on International Organization (UNCIO) in San Francisco was in view. She would have a small role, but to be recognized at all, as a woman and an outsider, was undoubtedly a boost to her confidence. The Conference, moreover, was going to take on the issue of International Trusteeship, a subject that was at the heart of her expertise, interests, and hopes.

\section{The Making of a Delegation}

During March of 1945, Ottawa was a hotbed of activity. Following the First Political Division's extensive assessment of the Dumbarton Oaks proposals for a new postwar international organization, ${ }^{473}$ Norman Robertson, the under-secretary of state for external affairs, marshalled the division to prepare for the San Francisco Conference.

"There was the need to prepare positions and to get the prime minister's approval of

${ }^{472}$ Hilliker, Canada's Department of External Affairs, Vol. 1, p. 278.

473 Blair Fraser, "Our Diplomats at Work," Behind the Headlines, Vol. 5, No. 3 (1945 Series), p. 7. The Department of External Affairs' First Political Division was created in January 1945 to oversee and report on international organizations. Its primary duty in early 1945 was to study the implications of the Dumbarton Oaks Proposals, and prepare advice for the government on the San Francisco Conference. 
them. And there were endless meetings to thrash out policy," stated Robertson's biographer, J. L. Granatstein. ${ }^{474}$ The Wartime Information Board (WIB), the successor to the Directorate of Public Information, ${ }^{475}$ was ordered to create and orchestrate an information campaign, which would school Canadians on the forthcoming United Nations Conference. ${ }^{476}$ A twenty-two page booklet, entitled Dumbarton Oaks Proposals, was created by the WIB to provide an overview and brief analysis of the text of the Dumbarton proposals. It was circulated to newspapers, periodicals, discussion groups, and citizen education groups. ${ }^{477}$ As part of its information campaign, the government provided Members of Parliament with detailed briefing notes on the proposals. As diplomat John Holmes later noted, this effort to involve the public in the discussion was an innovative aspect of Canada's preparation for the San Francisco Conference. ${ }^{478}$

474 J. L. Granatstein, A Man of Influence: Norman Robertson and Canadian Statecraft, 1929-1968 (Toronto: Deneau, 1981), p. 150.

${ }^{475}$ Hilliker, Canada's Department of External Affairs, Vol. 1, p. 274. The Wartime Information Board was established on September 9, 1942, succeeding the Directorate of Public Information. Its function was to facilitate distribution of Canadian war news and information at home and abroad.

${ }^{476}$ P. J. Philip, "Debate in Canada Clarifies Oaks Aim: Parliament Removes Public Misconceptions on Security," New York Times, March 24, 1945, p. 29. The proposal embodied the four-power declaration of the Dumbarton Oaks Conference of 1944. For a more detailed analysis of the Dumbarton Oaks Conference, see: Foreign Relations of the United States (FRUS), Vol. 1: General, 1944 (Washington D. C.: Government Printing Office, 1966); Dumbarton Oaks Conference, Proposals for the Establishment of a General International Organization (New York: Woodrow Wilson Foundation, 1944).

${ }^{477}$ Canada, Dumbarton Oaks Proposals (Ottawa: Wartime Information Board, n.d.); F. H. Soward, Canada in World Affairs: From Normandy to Paris, 1944-1946 (London: Oxford University Press, 1950), p. 130. Soward stated than more than 40,000 copies of the pamphlet were distributed throughout Canada.

478 John Holmes, The Shaping of Peace: Canada and the Search for World Order, 1943-1957, Vol. 1 (Toronto: University of Toronto, 1979), p. 245. Also, see: War Information Board, "Public Attitudes towards the San Francisco Conference," [n.d.], External Affairs Records, Library and Archives Canada (LAC), RG 25, Vol. 1021, File: 6-F, pp. 1-2. According to this preliminary memorandum, which reported the findings of an opinion survey conducted between April 6-10, 1945, 82 percent of Canadians, as compared to 62 percent of Americans, were aware and in favour of the forthcoming Conference. Its findings suggested that the Canadian government's information campaign had been successful. However, the survey also suggested that the government had been less successful in informing Canadians about the purpose of the Conference. Canadians generally understood it to be "an 
In late March 1945, a special session of Parliament was convened to endorse the prime minister's three-point plan ${ }^{479}$ — to accept the invitation to San Francisco for the United Nations' founding conference; to support Canadian membership in the new international organization; and to approve the purposes and principles set forth in the Dumbarton Oaks Proposals ${ }^{480}$ — as "a satisfactory basis for a discussion of the Charter of the proposed international organization." ${ }^{\prime 41}$ This open and frank discussion of foreign policy ran contrary to King's instinct, and yet it took place. ${ }^{482}$ After a week of sometimes heated debate on the issue, ${ }^{483}$ Parliament passed the government's motion by a vote of two-hundred and two to five. ${ }^{484}$

Before the special session ended, the prime minister announced the names of the members of the Canadian delegation to the forthcoming San Francisco Conference. For the first time in Canadian history, a sitting government had chosen an all-party delegation to represent the country. ${ }^{485}$ Encouraged by Robertson and Hume Wrong, the associate under-secretary state for external affairs, King would not repeat the same mistake that

international conference about world peace," not a conference to establish "an international organization for maintaining peace and dealing with aggression in the future." Over 30 percent of Canadians — but not Quebecers - were willing to leave future global security to the Big Five Powers.

479 Soward, Canada in World Affairs, p. 130. Soward noted that the Canadian government had already accepted the invitation but subsequently invited Parliament to endorse its acceptance of the invitation.

${ }^{480}$ Dumbarton Oaks Conference, See Chapter 1: Purpose and Chapter 2: Principles.

481 “5 Canadian M.P.’s Oppose Conference,” New York Times, March 29, 1945, p. 10.

482 Holmes, The Shaping of Peace, Vol. 1, p. 245.

483 “5 Canadian M.P.'s Oppose Conference,” p. 10. Also see: Soward, Canada in World Affairs, p. 131. Soward stated that "the sole opponents were independent members from Quebec, who objected, in the words of Wilfred Lacroix, to being 'irrevocably launched into a policy of internationalization and cooperation in the establishment of a programme of world security dependent on the good will of Stalin the dictator or which would be still worse, of international high finance.",

${ }^{484}$ Soward, Canada in World Affairs, p. 130.

485 Canada, Department of External Affairs Report on the United Nations Conference on International Organization, Conference Series, No. 2 (Ottawa: The King's Printer, 1945), p. 10. 
American president Woodrow Wilson had made in seeking to "monopolize international matters" for one political party at the Paris Peace Conference of 1919. Nevertheless, in choosing opposition members as part of the Canadian delegation, the prime minister had selected individuals, not given a voice to the other political parties. In his closing remarks to the special session, the prime minister stressed that, while his government would not prevent any member of the delegation from making their own views known, ${ }^{486}$ the sole responsibility for all positions adopted rested with the government. ${ }^{487}$

The delegation's composition was seen by the New York Times as tangible proof of "a real desire by the prime minister to keep security organization decisions above party politics. $" 488$ As a master of political manoeuvre, King saw the opposition members' presence and participation as a means of neutralizing any criticism of the delegation's deliberations on the eve of a federal election. Commentators, however, could and did claim that the government took the San Francisco Conference seriously, and no longer, as in days of the old League of Nations, saw international conferences simply as a means to bolster the country's status as an independent entity in international affairs. ${ }^{489}$ Journalist Blair Fraser enthused that the Canadian delegation arrived at San Francisco unified, confident, and well prepared. ${ }^{490}$

\footnotetext{
486 “5 Canadian M. P.’s Oppose Conference," p. 10.

${ }^{487}$ Holmes, The Shaping of Peace, Vol. 1, p. 246.

${ }^{488}$ P. J. Philip, "Wide Parley Voice Hailed in Canada," p. 23.

${ }^{489}$ F. H. Soward and Edgar McInnis, Canada and the United Nations (New York: Manhattan Publishing Company, 1956), p. 1.

${ }^{490}$ Fraser, "Our Diplomats at Work," p. 7.
} 
Supporting the delegates at the conference was a group of experienced senior advisors from External Affairs. At its heart were the department's three top officials: Norman Robertson, under-secretary of state for external affairs, Hume Wrong, associate under-secretary for external affairs, and Lester B. Pearson, the Canadian ambassador to the United States. Joining them were Dana Wilgress, Jean Désy, W. F. Chipman, and Major-General M. A. Pope, the Canadian ambassadors to the Soviet Union, Brazil, and Chile, and Military Staff Officer to the prime minister, respectively. ${ }^{491}$ In Robertson's view, the conference's dynamic was to be very fluid and rapidly changing. ${ }^{492}$ With four proposed commissions, and twelve technical committees, the government needed to ensure that its delegates were well prepared. ${ }^{493}$ Consequently, the under-secretary included a group of technical advisors to support the work of Canada's delegates and committees. ${ }^{494}$ The technical advisers included four foreign service officers: J. R. B. Chaput, Escott Reid, Paul-Emile Renaud, and Charles Ritchie. Rounding out this group were Louis Rasminsky, assistant to the governor of the Bank of Canada, and Elizabeth MacCallum, who was appointed as technical advisor to assist the delegation on matters concerning International Trusteeship. These advisers ensured that the delegates received timely answers to all the technical questions that were likely to arise during the course of the various committees' deliberations. They would also work with the technical

\footnotetext{
${ }^{491}$ Canada, Report on the United Nations Conference on International Organization, p. 10.

${ }^{492}$ Norman Robertson, "Memorandum for Members of the Canadian Delegation," April 4, 1945, External Affairs Records, LAC, RG 25, Vol. 1021, File: 6-F.

${ }^{493}$ Fraser, "Our Diplomats at Work," p. 8.

${ }^{494}$ Norman Robertson, "Informal Memorandum on Possible Organization the of Conference," External Affairs Records, LAC, RG 25, Vol. 1021, File: 6-F.
} 
committees in preparing amendments and drafting responses to the Charter's proposed principles and mechanisms. ${ }^{495}$

MacCallum's appointment to the delegation must have raised some eyebrows among the Canadian representatives. As Escott Reid later noted, “only five members of the Canadian External Affairs service below the rank of Ambassador were appointed to the delegation." ${ }^{496}$ Having been in External Affairs a mere three years, MacCallum's name would have been unfamiliar to the political members of the delegation. She was neither a professional diplomat of note, nor did she possess notable experience for such a landmark event. Nevertheless, Robertson trusted her judgment. MacCallum had already proven the value of having a Middle East specialist on staff, especially one who was conversant with the complex issues of International Trusteeship. There was little doubt that in the weeks and months to come that the formation of Trusteeships and Colonial policy would become - or ought to become - critically important to the establishment of the new organization. MacCallum's knowledge of the League of Nations' Mandates System would enable her to assist in giving the delegation an appreciation of the pitfalls and complexities of a new International Trusteeship system, and in assessing the Great Powers' proposed Trusteeship framework. ${ }^{497}$

\footnotetext{
495 Ibid. Also see: "Canadian Delegation Membership of Commissions and Committees," External Affairs Records, LAC, RG 25, Vol. 1021, File: 6-F.

${ }^{496}$ Escott Reid, Radical Mandarin: The Memoirs of Escott Reid (Toronto: University of Toronto Press, 1989), p. 193.

${ }^{497}$ See The Charter of the United Nations (Scranton, Penn.: The Haddon Craftsmen, 1945), Chapter 11, 12, and 13. These chapters dealt with the management of dependent territories, trust territories, and the Trusteeship Council, respectively.
} 
Just prior to the beginning of the conference, Canadian officials at External Affairs were blindsided by the unexpected news that U. S. President Franklin D. Roosevelt (FDR) had suddenly died on April 12, 1945, in Warm Springs Georgia. Speculations and editorial predictions about the upcoming conference fell to the wayside as newspapers and radio broadcasts across Canada covered Roosevelt's death. FDR was the chief architect of the new international organization and the San Francisco Conference. His vision for a new international entity was now seriously in jeopardy. With his death, stated historian Peter Clarke, the slate had been washed clean of any and all commitments made to the Allies by the American president. ${ }^{498}$ Canadian officials speculated whether the San Francisco Conference would or should even go forward. ${ }^{499}$

\section{MacCallum, Trusteeship, and Palestine}

Hume Wrong characterized MacCallum as a "person with a well-defined point of view." To Wrong and other officials in the department, such as George Glazebrook, ${ }^{500}$ she had demonstrated an expertise in some of Canada's key postwar foreign policy issues - Great Power politics, the Arab-Jewish dispute, and the fate of the postwar Mandate system. She, like Wrong, never backed away from asserting a contentious position; there was never a doubt where she stood on an issue. She exuded a quiet confidence, which

\footnotetext{
498 Peter Clarke, The Last Thousand Days of the British Empire (New York: Bloomsbury Press, 2008), p. 294.

499 J. W. Pickersgill and D. F. Forster (eds.), The Mackenzie King Record: Vol. 2, 1944-1945 (Toronto: University of Toronto Press, 1968), p. 360.

500 George Glazebrook, "Memorandum for Mr. Wrong," December 22, 1943, External Affairs Records, LAC, RG 25, Vol. 1839, Part 2; Hume Wrong, "Memorandum for Mr. St. Laurent," [n.d.], External Affairs Records, LAC, RG 25, Vol. 1839, Part 2.
} 
reflected a sound judgment of the facts and a reasoned understanding of the political and diplomatic impacts of policy positions.

As noted in previous chapters, MacCallum's experiences and studies of the Middle East informed her critical view of the Western imperial powers and her belief that their policies had had a disastrous impact on political, cultural, and economic development in lesser-developed territories. MacCallum embraced the Wilsonian view that Western colonialism and imperialism were obstacles to international co-operation and stability. She, moreover, believed that, as long as imperial interests dictated the actions of the Great Powers and dominated international organizations, international collaboration and peace would be difficult to achieve.

MacCallum's concerns about the Great Powers and their intentions regarding International Trusteeship during the United Nations Conference were presaged in her interwar commentaries and her departmental analyses of the Palestine issue and the Yalta Communiqué. MacCallum's perspectives, when examined collectively, reveal a consistent and cohesive worldview that shaped her thoughts about the United Nations Conference, the work of the Trusteeship Committee, and ultimately, Canada's approach to the management of dependent territories and peoples. She believed that the International Trusteeship System, as an instrument conceived and controlled exclusively by the Great Powers, was destined to fail.

This outlook was rooted in three assumptions running consistently throughout her writings. First, she believed that it was unlikely that the Great Powers could overcome their colonial and imperial impulses to make the co-operative management of dependent 
territories viable. ${ }^{501}$ Second, she reasoned that an International Trusteeship system would be unworkable as long as the Great Powers were determined to maintain exclusive control over its design, policies, and administration. ${ }^{502}$ Third, MacCallum was firmly convinced that Trusteeship's credibility and effectiveness were inextricably linked to the Palestine Mandate, a lens through which smaller powers viewed the new organization's legitimacy, and yet a problem that the Great Powers, particularly Great Britain, seemed unable or disinclined to confront.

MacCallum's analysis of the Yalta Communiqué had confirmed what she and the department had already suspected: ${ }^{503}$ Great Power relations had become increasingly discordant. ${ }^{504}$ Uncertainty, mistrust, and competition had supplanted the resolve and cooperativeness that had previously characterized the Allied wartime relationship. Rather than promoting a collaborative postwar international system that respected "sovereign equality," ${ }^{205}$ Yalta exposed not only the Great Powers' determination to continue the practice of balance of power politics, but also the emergent fault lines in their grand alliance over the postwar colonial system and the role that the new international organization would play in global politics. There was a striking lack of consensus with respect to International Trusteeship and colonial policy, as reflected in their near

\footnotetext{
${ }^{501}$ Elizabeth MacCallum, "The International Problem in Tangier," Foreign Policy Association Information Service (FPAIS), Vol. 2, No. 15 (September 29, 1926), pp. 170-71.

502 Elizabeth MacCallum, "The French Mandate in Syria," Editorial Information Service (EIS), Series 1925-26, No. 5 (December 5, 1925), pp. 1-3.

${ }^{503}$ Hume Wrong, "Assistant Under-Secretary of State for External Affairs to First Secretary, High Commission in Great Britain," March 6, 1944, in Document in Canadian External Relations (DCER), Vol. 11, 1944-45, Part 2 (Ottawa: Supply and Services Canada, 1990), pp. 576-77.

504 Adam Chapnick, The Middle Power Project: Canada and the Founding of the United Nations (Vancouver: UBC Press, 2005), p. 115.

${ }^{505}$ Soward, Canada in World Affairs, p. 128.
} 
omission from the Dumbarton Proposals of 1944, the Yalta Communiqué of 1945, and in the heated discussions emanating from Tehran and Moscow Conferences of 1943.506

The Yalta Communiqué also confirmed for MacCallum that the Big Three Powers had returned to the traditional notions of Great Power politics. Virtually every issue was viewed through the prism of diverging postwar territorial and security requirements. This raw Great Power calculus was articulated in the Communiqué, where the Soviets declared their desire to establish a cordon sanitaire around the liberated Eastern Europe States — Poland, Czechoslovakia, and Yugoslavia — thereby ensuring that the Soviets would become the dominant political and economic power in the region. ${ }^{507}$ In effect, the Soviets were determined to establish a colonial or satellite system beyond the scope of the new security organization.

The Americans were themselves outspoken in their determination to expand their influence and control. With the demise of British and French imperial power in the Far East by 1942, and the end of Japan's dreams for a Pan-Asian Empire by 1945, the United States military expressed a strong desire to annex the former Japanese mandated islands in the Western Pacific. ${ }^{508}$ In doing so, they acknowledged their ambition to seize strategic

506 Elizabeth MacCallum, “The Crimea Conference,” March 25, 1945, King Papers, LAC, MG 26, J4, Vol. 310. In MacCallum's précis of the Yalta Communiqué, she described Stalin's attempts to keep the London Poles in exile, and allow the pro-Soviet Warsaw Poles to remain in power. She also described the determination of the pro-Soviet Tito forces in Yugoslavia to take power. The partitioning of Germany into Allied sectors confirmed Stalin's aim to consolidate large portions of Eastern European territory, or at the very least, neutralize territories that the Soviets could not control or directly influence.

507 Ibid.

${ }^{508}$ Edward Stettinius Jr., "Secretary of State to President Roosevelt," Edward Stettinius, April 9, 1945, in FRUS, Vol. 1, General: United Nation, p. 211. Stettinius told the president that the Secretaries of War and the Navy expressed the view that the U. S. Government "should retain complete control over certain strategic areas in the Pacific and that we should make this known unequivocally to other nations and to 
control of the Western Pacific, and thus protect their previously exposed sea lines of communication. ${ }^{509}$ The annexation of these territories would ensure that the Americans would play a larger role in Far Eastern affairs in the postwar period. The British were meanwhile resolved, in association with France and the Netherlands, to maintain a tight grip on their colonial and mandated territories without interference from the new world organization. MacCallum could see that the fate of the postwar order rested almost exclusively with the Great Powers.

As the Yalta Communiqué stipulated, the United Nations Conference in San Francisco would replace the League of Nations' Mandate System with an International Trusteeship System. ${ }^{510}$ The Trusteeship System would place under its authority the League's Mandate territories and colonial territories seized by the Axis Powers during the Second World War. The purpose of an International Trusteeship system, as American political scientist Quincy Wright stated, was to establish a "better system for the administration of backward areas than has existed under the regime of colonies, protectorates, or spheres of influence — better in the sense that it would more effectively secure the liberty, material welfare, and opportunity for development of the native

the world . . they believe that the United States policy should be to hold any reserve strategic rights in a very real sense as trustee in the interests of the same cause for which we are now fighting."

${ }^{509}$ For a detailed explanation of the term, see: Alfred Thayer Mahan, The Influence of Sea Power Upon History, 1660-1783 (Boston: Little, Brown and Co., 1890), p. 34. The term "sea lines of communication" is generally described as the primary sea or trade routes between ports; it is also considered by naval historians and strategists as a necessary element of Mahan's Command-of-the-Sea doctrine.

510 Arthur N. Holcombe, "The International Trusteeship System," Annals of the American Academy of Political and Social Science, Vol. 246, Making the United Nations Work (July, 1946), p. 101. The Great Powers negotiated, behind closed door, an agreement on the draft provisions regarding the International Trusteeship System and Trusteeship Council, before presenting it to the General Assembly. 
inhabitants. . .."511 The future Trusteeship Council was the organ of the United Nations chosen to supervise the nations administering the trust territories. It was to be given more powers than the League's Permanent Mandates Commission in carrying out this responsibility.

While, in theory, MacCallum considered International Trusteeship a legitimate mechanism for assisting dependent peoples in the achievement of political maturity and independence, she believed that, if the Great Powers maintained control, it would fall far short of its intended aim. ${ }^{512}$ This was not a new phenomenon for MacCallum. She had witnessed how the victorious European powers of the First World War had used the principle of Trusteeship to seize control of the former territories and colonies from the defeated Ottoman and German Empires, adding them to Western imperial holdings. In her judgement, the Allies had exercised no regard for the rights of dependent peoples they were pledged to protect. For MacCallum, Trusteeship, and the Mandates System in particular, was a façade that camouflaged the Great Powers' efforts to seize resource-rich and strategically valuable territories without fear of domestic or international condemnation or reprisal. ${ }^{513}$ This view was especially evident in MacCallum's various assessments of the Palestine Mandate. ${ }^{514}$

\footnotetext{
${ }^{511}$ Quincy Wright, Mandates Under the League of Nations (New York: Greenwood Press, Publishers, 1930), p. 64.

${ }^{512}$ MacCallum, "The French Mandates in Syria," p. 2.

${ }^{513}$ Elizabeth MacCallum, “The Middle East,” MacCallum Papers, [n.d.], (Unpublished paper), p. 1.

514 Elizabeth MacCallum, "The Palestine Conflict," Foreign Policy Association Information Service (FPAIS), Vol. 5, No. 16 (October 16, 1929); "Great Britain and the Race Problem in Palestine," Foreign Policy Report (FPR), Vol. 10, No. 13 (August 29, 1934).
} 
In MacCallum's estimation, the Big Three Powers were prepared once again, in the aftermath of a Second World War, to construct a Trusteeship mechanism that endorsed their immediate strategic requirements. For her, the Great Powers' desire to dominate the Trusteeship system was manifested in several ways. The major powers ensured that all discussions pertaining to the construction of a Trusteeship system were conducted exclusively through their wartime conferences. Beginning in 1941 and ending in 1945, there were nine wartime conferences attended by Britain, United States, and the Soviet Union. Yet, none of the conferences involved the lesser powers or the territories involved, MacCallum reported. ${ }^{515}$ Roosevelt, Churchill, and Stalin had collectively crafted at Yalta a formula through which the principles and mechanisms of the Trusteeship system would operate. In doing so, they unilaterally defined what territories would fall under international supervision. More importantly, they made sure that colonial reform was gradual and would not occur without the consent of the colonial powers.

MacCallum saw the Trusteeship arrangement as an imperial condominium, which maintained and ensured the Great Powers' strategic interests, addressed Anglo-American differences, and prolonged the existing colonial system. In that condominium, the Great Powers determined the fate of millions of people without their consent. ${ }^{516}$ Churchill made

\footnotetext{
${ }^{515}$ Elizabeth MacCallum, “The Crimea Conference,” March 25, 1945, King Papers, LAC, MG 26, J4, Vol. 310, pp. 4-5.

516 MacCallum had written extensively on Imperial condominiums and commercial multi-dominiums during the interwar period for the Foreign Policy Association. In particular, she wrote on the French and Spanish quasi-mandate in Morocco, under the General Act of the Conference of Algeciras of 1906. See: "The International Problem of Tangier," FPAIS, Vol. 2, No. 15 (September 29, 1926), pp. 168-180; "American Oil Interests in Mesopotamia," FPAIS, Vol. 2, No. 6 (May 22, 1926), pp. 68-77.
} 
it clear at Yalta that he would brook no interference from lesser powers. He chided the Americans and warned them that "under no circumstances would he ever consent to forty or fifty nations thrusting interfering fingers into the life's existence of the British Empire." 517 Stalin concurred with Churchill's view: "He would never agree to having any action of any of the Great Powers submitted to the judgement of the smaller powers." MacCallum's belief that Trusteeship was a Great Power compact was further strengthened by the decision taken at Yalta to hold informal "conversations" among the major powers, prior to the San Francisco Conference, to draft the framework for the new Trusteeship System. The decision to pre-empt the Conference's deliberations must have led MacCallum to conclude that the major powers were only willing to submit the issue to the international community after it had been decided. In her mind, the Great Powers were determined to deny the lesser powers, Canada included, any role or say in formulating the principles and mechanisms for a Trusteeship System. Thus, International Trusteeship would not be decided by the world community. This constituted a mockery of the Big Three's stated principle of sovereign equality. ${ }^{519}$

The greatest of MacCallum's concerns about the Trusteeship deliberations was the Arab-Jewish dispute over Palestine. She was certain that Palestine would spill over into the Trusteeship Committee's deliberations and thereby have a deleterious effect on the committee's work, and exacerbate tensions in Great Power relations. While the Big

\footnotetext{
517 Charles Bohlen, "Bohlen Minutes," February 9, 1945, in FRUS, The Conferences of Malta and Yalta, 1945 (Washington D. C.: Government Printing Office, 1955), p. 844.

518 Alexander Dallin, The Soviet Union and the United Nations: An Inquiry into Soviet Motives and Objectives (New York: Frederick A. Praeger, 1962), p. 22.

${ }^{519}$ Soward, Canada in World Affairs, p. 128.
} 
Three had agreed not to discuss any specific territory or Mandate at San Francisco, ${ }^{520}$ it was evident to MacCallum that the question of Palestine was unavoidable. Since the fall of 1943, she had been given the opportunity to comment on and draft official Canadian responses to both Zionist and Arab concerns about Palestine. ${ }^{521}$ This had given her an official vantage point and inside information on the growing problem emerging out of Palestine, and it confirmed her suspicions that both the Arabs and Zionists would use the San Francisco Conference to further their political aims in Palestine.

By the spring of 1945, MacCallum had come to realize that the Arab-Jewish struggle would dominate the Trusteeship Committee's efforts to establish a framework for addressing dependent territories. For months leading up to the conference, MacCallum witnessed a torrent of Zionist lobbying, the goal of which was to bring the issue of Palestine to San Francisco. ${ }^{522}$ On March 9, 1945, for example, Sir Ellsworth Flavelle, chairperson of the Canadian Palestine Committee, petitioned the King government to allow that, since five Arab States were to be represented at the United Nations Conference, the same opportunity should be given to the Jewish people. ${ }^{523} \mathrm{He}$

520 David Bercuson, Canada and the Birth of Israel: A Study in Canadian Foreign Policy (Toronto: University of Toronto Press, 1985), p. 30. Fearing how divisive the Palestine issue was, Churchill announced in February 1945, two months before the commencement of the conference, that the Palestine Mandate would not be considered at San Francisco. Britain would continue to administer the Mandate without United Nations interference.

${ }^{521}$ Mackenzie King, "Letter to Mr. Freiman,” December 24, 1943, External Affairs Records, LAC, RG 25, Vol. 1839, Part 2, p. 593. See: Norman Robertson, "Memorandum to the Prime Minister," December 24, 1943, External Affairs Records, LAC, RG 25, Vol. 1839, Part 2, p. 593. According to the undersecretary of state's note to the prime minister, MacCallum drafted the letter to Mr. Freiman.

522 “A Task for the United Nations," Toronto Star, January 29, 1945, p. 6. Also see: "Need for Jewish Delegates at San Francisco Stressed," Globe and Mail, March 23, 1945, p. 12; "Ask Guarantee for Europe Jews," Globe and Mail, April 5, 1945, p. 8.

${ }^{523}$ Canadian Palestine Committee, "Memorandum to Prime Minister of Canada," March 9, 1945, External Affairs Records, LAC, RG 25, Vol. 1839, Part 3, p. 593. 
requested that the prime minister propose to President Roosevelt that the World Zionist Organization or the Jewish Agency in Palestine should be invited to the Conference as the representatives of the Jewish nation. ${ }^{524}$ All the Zionist efforts to convince Ottawa to help them get invited to participate in the San Francisco Conference failed. Nevertheless, MacCallum was convinced that they would not relent.

MacCallum noted similar efforts in the United States. In April 1945, on the eve of the San Francisco Conference, in meetings with State Department officials, the American Jewish Conference (AJC), composed of sixty organizations representing every major Jewish community in the United States, insisted that it was only "elementary justice" that the voice of the Jewish people should be heard at the world conference. The American Zionists also submitted a petition requesting the right to present to the appropriate committees of the United Nations Conference:

an International Bill of Rights, to speed the reconstitution of Palestine as a Jewish Commonwealth, to restore the civil and political rights of Jews in Europe, to undertake measures for their rehabilitation and resettlement and restoration of their property confiscated by the Nazis and their collaborators, and to punish those responsible for war crimes against the Jewish people. ${ }^{525}$

Such actions in the United States and Canada made it clear to MacCallum that the Zionists were not willing to rely on the offices of their national governments to represent their interests in Palestine. They wanted the international community to recognize Palestine as a de facto Jewish state, which had a right to represent its own interests at all international conferences. Thus, they were determined to use the San Francisco

\footnotetext{
524 Ibid.

525 “Jewish Groups Asks Hearing at Parley,” New York Times, April 3, 1945, p. 23.
} 
Conference to plead their case to the world. To MacCallum, this was just one part of the Zionists' new approach to Palestine, which had emerged with the proclamation and adoption of the Biltmore program in $1942 .{ }^{526}$ As international relations professor Alan Taylor put it, the Biltmore program led to one incontestable conclusion: the Zionists were fully committed to the creation of a Jewish state in Palestine, even if it meant war with the Arabs. The Zionists refused to countenance a permanent minority status, and they were not willing to accept the establishment of a binational state in Palestine. ${ }^{527}$

The Zionists, however, were not alone in their desire to use the upcoming San Francisco Conference to secure Palestine's fate. Given the Zionists' public statements regarding the Biltmore Program, the Arabs anticipated that the Zionists would make every effort at San Francisco to end the British Mandate, nullify the White Paper of 1939, and intensify their demand that the Jewish Agency take immediate control of immigration into Palestine. On March 17, 1945, just over a month before the Conference began, the newly created League of Arab States met in Cairo and prepared the Arab campaign for participation in the United Nations Conference. ${ }^{528}$ The New York Times ${ }^{529}$ reported that there was only one issue at stake in the minds of the Arab leaders: the full independence

526 Alan R. Taylor, Prelude to Israel: An Analysis of Zionist Diplomacy, 1897-1947 (New York: Philosophical Library, 1959), pp. 58-60. On May 11, 1942, a conference of American, European, and Palestinian Zionists convened at the Biltmore Hotel in New York to decide how to proceed in establishing the Jewish state. Commonly known as the Biltmore Conference, the meetings led to the adoption of a set of resolutions collectively referred to as the Biltmore Program. The program contained a set of protocols for a new policy towards Palestine. On November 6, 1942, the World Zionist Organization endorsed the program.

${ }^{527}$ Ibid, pp. 59-60.

${ }^{528}$ In 1945, the League of Arab States was composed of Egypt, Iraq, Lebanon, Saudi Arabia, Syria, Transjordan, and Yemen. The last two of these states had not been invited to the San Francisco Conference.

${ }^{529}$ Sam Pope Brewer, "7 Arab Countries Study Next Moves," New York Times, March 18, 1945, p. 18. 
and sovereignty of all Arab nations. This meant addressing the future status of Palestine, ${ }^{530}$ because, as MacCallum knew and preached, Palestine was crucial in Arab identity. ${ }^{531}$ While it was unmistakable that the Arab states were growing politically and economically apart, Palestine continued to be the thread that unified them. The Pact of the League of Arab States substantiated this interpretation. As Annex 1 of the Pact clearly showed, the Arabs believed they had legal rights to Palestine.

Even though Palestine was not yet able to control its own affairs, the Covenant of the League in 1919 made provision for a regime based upon recognition of its independence. Its international existence and independence among the nations can, therefore, no more be questioned, de jure, than can the independence of the other Arab countries. ${ }^{532}$

The Arab League's declaration confirmed MacCallum's suspicion that Palestine would be the focal point of Arab demands during the United Nations Trusteeship deliberations. On numerous occasions, the Arabs had laid bare their concerns about Palestine to the American and British governments, which both had significant economic interests in the Middle East. The Arabs made their intentions clear: there would be profound repercussions if unlimited Jewish immigration into Palestine was not halted. While sympathetic to the Jewish refugee crisis, the Arabs did not believe that the Zionist demand for control of immigration into Palestine was a result of the refugee crisis in

\footnotetext{
${ }^{530}$ Ibid.

${ }^{531}$ Elizabeth MacCallum, "Palestine: Postwar Policy and the White Paper," [n.d.], King Papers, LAC, MG 26, J4, Vol. 310, C214548.

532 "Egypt-Iraq-Lebanon-Saudi Arabia-Syria-Transjordan-Yemen: Text of the Pact of the Arab League," The American Journal of International Law, Vol. 39, No. 4, Supplement: Official Documents (October 1945), p. 271.
} 
Europe. The Zionists were undoubtedly using the argument to further the creation of a Jewish State in Palestine. ${ }^{533}$

MacCallum also knew that the Arabs had little faith that the Great Powers would protect Arab rights and interests at San Francisco. After all, the Americans, British, and French had already betrayed them on numerous occasions: repudiating the HusaynMcMahon Agreement, the secret Sykes-Picot Agreement, and honouring Roosevelt's pledges to the Arabs. ${ }^{534}$ It was now entirely possible, under pressure from American Zionist groups, that the Great Powers would introduce measures at San Francisco to open Palestine's gates to millions of postwar Jewish refugees from Europe without the consent of Palestine's majority population. Moreover, the Arabs feared that the Zionists' efforts would not stop at Palestine; they would attempt to seize Transjordan and parts of Southern Syria as well. There was little inclination on the Arabs' part, therefore, to have any confidence in the Great Powers, which had so far accommodated Zionist ambitions time and again. MacCallum recognized that the Palestine question had built an enormous critical momentum. Any attempt to delay its discussion would only breed further suspicion and anger in the Arab World. If the Great Powers tried to sidestep the issue,

${ }^{533}$ MacCallum, "Palestine: Postwar Policy,” C214548.

534 "Statement to the Press," May 25, 1945, in FRUS, Vol. 1, p. 926. Roosevelt, following the Yalta Conference, travelled to Egypt on February 13-14, 1945, and met with King Farouk of Egypt, Emperor Haile Selassie of Ethiopia, and King Abdul Aziz al-Saud of Saudi Arabia. Each, in turn, demanded that Palestine's immigration quotas remain unchanged — according to the British White Paper of 1939 and they also indicated that they would go to war if quotas were changed under the proposed United Nations Charter. The U. S. president pledged to do nothing that would harm the Arabs. 
even temporarily, they risked imperilling the prestige of the new world organization and the "stability of the postwar arrangements as a whole." 535

\section{"There is Really Nothing to be Discussed There"}

On April 23, 1945, the Canadian delegation arrived in San Francisco by special trains and chartered aircraft. The 36-member delegation was billeted along with 26 other delegations at the 32-story, turn-of-the-century Sir Francis Hotel near Union Square. It was a chaotic and confusing time; "no one seemed to know what they were doing," recalled Lester Pearson. ${ }^{536}$ For MacCallum, her early duties were light. There was little to do until the Great Powers presented their tentative proposals to the Trusteeship Committee. In the meantime, she took the occasion to attend some of the social functions offered by the Conference. It was a chance not only to meet members of the other delegations, especially women delegates, but an opportunity to obtain valuable information concerning the characteristics and the points of view of foreign representatives and their delegations.

Of the fifty governments represented at the San Francisco Conference, only twelve delegations had women members with functions other than secretarial and clerical. There were only six women delegates, representing approximately two percent of the total number of delegates, and fifteen assistant delegates, advisers, consultants, counselors or

\footnotetext{
${ }^{535}$ MacCallum, “Palestine: Postwar Policy,” C214548.

${ }^{536}$ Lester B. Pearson, Mike: The Memoirs of the Right Honourable Lester B. Pearson, Vol. 1, 1897-1948 (Toronto: University of Toronto Press, 1972), p. 273.
} 
experts. ${ }^{537}$ Thus, MacCallum was in a rarefied group. Conference women got together in informal and intimate settings. The various women's organizations and delegates to the Conference hosted numerous teas and luncheons. It was at one of these gatherings that Virginia Gildersleeve, dean of Columbia University's Barnard College, and the lone woman on the American delegation, met MacCallum. The "very intelligent Canadian ... who knew a lot about the Near East" immediately impressed her. ${ }^{538}$ They had a lot in common: they had both studied at Columbia, had a shared passion for Middle East and Arab politics, and a keen interest in the deliberations of the Trusteeship Committee. Most of the women delegates to the Conference, recalled Gildersleeve, were consigned to the committee overseeing the Economic and Social Council. The American delegate speculated that the work of the Council was regarded as a "suitable feminine field." 539 MacCallum, however, was Canada's "special adviser" to the Trusteeship Committee, a committee with which Gildersleeve would have preferred to be associated. ${ }^{540}$

At the commencement of the Second Plenary Session of the Conference, held in the San Francisco War Memorial Opera House on April 27, 1945, Canadian Prime Minister Mackenzie King told participants and onlookers that the Canadian delegation's overall approach to the United Nations deliberations was "to co-operate as completely as it could

\footnotetext{
${ }^{537}$ Torild Skard, "Getting Our History Right: How were the Equal Rights of Women and Men included in the Charter of the United Nations?" Norwegian Institute for International Affairs, No. 1 (June, 2008), p. 43.

${ }^{538}$ Virginia Crocheron Gildersleeve, Many a Good Crusade (New York: The MacMillan Company, 1955), p. 351.

${ }^{539}$ Ibid, pp. 330-331.

${ }^{540}$ Ibid, p. 331.
} 
with the delegations of other nations in bringing into being, as soon as possible, a Charter of world security." ${ }^{, 541}$ King added that:

It is not the intention of the Canadian delegation to put forth in plenary session special amendments to the proposals. Our delegation will express its point of view at an appropriate time and place on specific questions as they arise. Our sole preoccupation in any amendment, which we may put forward or support at a later stage, will be to help in creating an organization, which over the years and decades to come will be strong enough, and flexible enough to stand any strains by which it may be subjected. ${ }^{542}$

In other words, the Canadian delegation's general aim was "to build the most efficient organization possible without estranging from it the Great Powers upon whose participation its success must depend. ${ }^{, 543}$ As diplomat John Holmes recalled, this meant not pushing points of view that might endanger the lively participation of the United States in the organization. ${ }^{544}$ A deferential approach to the Great Powers was in keeping with the prime minister's preferred role and tactic, which encouraged consensus among the British and American delegations, while rebuffing Soviet efforts to highlight difference.

King's attitude was particularly evident in Canada's approach to the Trusteeship deliberations. The official Canadian Report on the United Nations Conference recorded that the delegation, "because of the lack of any direct responsibility on the part of the

\footnotetext{
${ }^{541}$ Canada, Report on the United Nations Conference on International Organization, p. 10.

${ }^{542}$ Ibid, p. 11. Also see: "Minutes of Meeting of Canadian Delegation, United Nations Conference on International Organization," April 27, 1945, in DCER, Vol. 11, 1944-45, Part II, pp. 751-752. "The prime minister opened the meeting by stating that he thought that the Canadian delegation would be best advised to withhold suggestions for amendment and positive comment for the time being ...."

${ }^{543}$ Soward, Canada in World Affairs, p. 137.

${ }^{544}$ Holmes, The Shaping of Peace, Vol. 1, p. 254.
} 
Canadian Government for the administration of Colonial dependencies, took no active part in the discussions, but followed them with close attention." ${ }^{545}$ A review of the minutes of the Canadian delegation's meetings confirms that the issue of Trusteeship seldom appeared. While these meetings do not represent the full measure of Canada's deliberations on the subject, they do offer a good perspective on the general approach and attitude of the delegates towards Trusteeship. And they go a long way in explaining MacCallum's attitude to the delegation's approach.

Twenty-three officially recorded meetings of the Canadian delegation took place between April 25 and June 19, 1945. When the prime minister was in attendance, ${ }^{546}$ they were the nexus of Canada's foreign policy decision making, affirmed John Hilliker. ${ }^{547}$ Yet, in a May 8th diary entry, the prime minister stated that: "I did not attend [the] meeting with members of the Canadian delegation. There is really nothing to be discussed there. The whole purpose is to keep the group in good humour." ${ }^{\circ 48}$

Trusteeship was discussed only six times at the meetings of the Canadian delegation. ${ }^{549}$ What is more, when it was discussed, it was in the form of a report presented by the principal Canadian official to the Trusteeship Committee. There were few open discussions about the ongoing developments in the Committee, and there were

\footnotetext{
${ }^{545}$ Canada, Report on the United Nations Conference on International Organization, p. 49.

546 Pickersgill and Forster, The Mackenzie King Record, Vol 2, p. 386. Mackenzie King left the San Francisco Conference on May 14, 1945 and returned to Vancouver to attend his first election meeting.

${ }^{547}$ Hilliker, Canada's Department of External Affairs, Vol. 1, p. 306.

${ }^{548}$ Pickersgill and Forster, The Mackenzie King Record, Vol. 2, p. 382.

549 R. G. Riddell, "Minutes of Meetings of the Canadian Delegation from April 27 to June 19, 1945," External Affairs Records, LAC, RG 25, Vol. 1021, File: 6-F.
} 
certainly no debates about Canada's position. The format of the meetings and the lack of debate among the delegates may have reflected Norman Robertson's careful vetting of each report. It was customary for the principal delegate to each committee to brief the under-secretary in the mornings, prior to presenting findings to the whole delegation. ${ }^{550}$ As a result, the reports tended to concentrate on Canada's two major goals: running interference for the United States and Great Britain and softening the message that those two powers delivered to the Soviet Union and China.

Privately, MacCallum must have been frustrated not only by the Canadian government's decision to remain silent during the Trusteeship discussions, but also that she was not given an opportunity to utilize her knowledge and skills. Trusteeship was the one area where she felt confident that she could have made a contribution. MacCallum must have also been perplexed by the logic of the government's decision to play a passive role in the Trusteeship Committee's discussions. This position appeared to run contrary to the activist mood of the country and the department's "enthusiastic response" to the new role that the United Nations Organization would create for External Affairs. ${ }^{551}$

At the heart of MacCallum's reservations about Canada's approach to Trusteeship was apt to be three concerns: the Great Powers' intentions towards Trusteeship; the Anglo-American disagreement over dismantling the Colonial System; and the British Palestine Mandate dispute. As a witness to interwar events, and, subsequently, to the diplomatic démarches that took place during the latter half of the Second World War,

\footnotetext{
${ }^{550}$ Escott Reid, Radical Mandarin, p. 194.

${ }^{551}$ Hilliker, Canada's Department of External Affairs, Vol. 1, p. 304.
} 
MacCallum saw little evidence that the colonial powers had substantially altered their attitude towards administering dependent territories. In fact, by 1945 they had attempted to strengthen and insulate their Empires from future international interference or scrutiny. Britain introduced the British Colonial Development and Welfare Bill, ${ }^{552}$ the French proposed to unite all of their colonies into a union controlled and administered by Paris; and the Dutch were preparing to integrate their colonies into the Dutch state. ${ }^{553}$ MacCallum had seen, in both the Covenant of the League of Nations and the Versailles Treaty, how Article 22 was conceived and used by the Great Powers to preserve and expand their colonial empires. ${ }^{554}$ Instead of building accountability and safeguards into the Covenant, as promised by the Great Powers at Versailles, Article 22 only succeeded in providing the colonial powers a larger imperial landscape within which to work. Without enforcement or exculpatory mechanisms, the Great Powers were free to disregard the "wishes of the mandatory communities" and world opinion. ${ }^{555}$

${ }^{552}$ E. R. Wicker, "Colonial Development and Welfare, 1929-1957: The Evolution of a Policy," Social and Economic Studies, Vol. 7, No. 4 (December, 1958), p. 184. The Colonial and Welfare Act of January 31,1945 , was an overall plan to increase by $£ 120$ million British investment in their Colonial Empire. While the new investment scheme did improve the living conditions for Britain's Colonial peoples, it did not change their status as dependent peoples.

${ }^{553}$ Huntington Gilchrist, "V. Colonial Questions at the San Francisco Conference," The American Political Science Review, Vol. 39, No. 5 (October, 1945), p. 982. Also, see: C. A. Julien, "From the French Empire to the French Union," Royal Institute of International Affairs, Vol. 26, No. 4 (October, 1950), pp. 492-493. The French Imperial Conference of January 30-February 8, 1944, held at Brazzaville, Congo, proposed Colonial reforms, which attempted to strengthen France's grip on its African Colonies, not establish a path towards independence or self-government.

${ }^{554}$ H. Duncan Hall, Mandates, Dependencies, and Trusteeship (London: Stevens \& Sons Limited, 1948), p. 3. Hall argued that international frontiers were contested areas among the Great Powers, as in the case of the Anglo-French desires for the former Ottoman provinces. Article 22 was an attempt to put a patch on the Anglo-French contest by dividing the territories in mandated lands, which both parties would administer. For further detail on Mandate territories, see: Elizabeth MacCallum, "The French Mandate in Syria," EIS, Series 1925-1925, No. 5 (December 5, 1925), 1. Article 22 was embodied in both the Treaty of Versailles and the League of Nation Covenant.

${ }^{555}$ See League of Nations Covenant, Article 22. 
It was obvious to MacCallum that post-World War One Britain and France felt a far greater duty to their own Empires than they did to the Covenant's guiding principles on international stewardship. In the case of the British Mandate in Palestine, MacCallum saw an agreement that manipulated both Arab and Jewish desires for statehood, and encouraged the hatred and suspicions between the two political adversaries. The Mandate agreement, made without consultation with the indigenous population, ran contrary to the will and interests of the majority in Palestine. The British had created a culture of conflict and bloodshed that would continue for decades to come.

In Syria and the Lebanon, France's promises had been equally empty. They failed to discharge their pledge to develop self-governing democratic institutions and ensure the well-being of the Syrian population. To make matters worse, the French partitioned the Syrian territory into five provinces, and imposed a harsh military and autocratic rule over the Arab inhabitants. When confronted with a call from Syrian Arabs for greater personal liberties and democratic self-government, as promised in the Franco-Syrian Mandate agreement of September 1923, the French responded with brutal force and repressive measures to quell all democratic demands. ${ }^{556}$ Each mandated Arab territory suffered a similar fate under British and French administrations. MacCallum concluded that the League's Mandate system in general, and the Class A Mandates in particular, had failed to deliver on their promise of international stewardship and security for dependent

\footnotetext{
${ }^{556}$ Elizabeth MacCallum, The Nationalist Crusade in Syria (New York: The Foreign Policy Association, 1928), p. 127. For further analyses on the Syrian mandate, see: Sandra Mackey, Lebanon: A House Divided (New York: W. W. Norton \& Co., 1989); Michael Provence, The Great Syrian Revolt and the Rise of Arab Nationalism (Austin, TX: University of Texas Press, 2005); and, Quincy Wright, "Bombardment of Damascus," The American Journal of International Law, Vol. 20, No. 2 (April 1926), pp. 263-280.
} 
peoples. The Mandate system revealed itself to be a mechanism designed by and for the European imperial powers.

\section{Anglo-American Differences, and Canada in the Middle}

Equally alarming to MacCallum was the Anglo-American rift over British colonial policy, a subject that requires the following sketch of wartime developments in that domain. As MacCallum could see, two very different postwar visions emanated from Washington and London. Tensions had been growing between the two governments regarding the future of the colonial system and the fate of dependent territories. These tensions found their roots in the wartime views and declarations of Franklin D. Roosevelt, the anti-imperialist American president, and Winston Churchill, the staunch imperialist prime minister and the defender of the British Empire. While both leaders had departed their national scenes, their strong convictions continued to shape both nation's attitudes and policies.

Roosevelt was committed to ending imperialism and the colonial system. His wartime government made no secret of its distaste for imperialism, and British imperialism in particular. ${ }^{557} \mathrm{He}$ was convinced, despite the existence of an informal American Empire, that the maintenance of the colonial system was no longer a legitimate ${ }^{558}$ or moral policy. The wretched conditions in French Indo-China and Gambia were evidence for the president; their administrations were tantamount to slavery and

\footnotetext{
${ }^{557}$ Wm. Roger Louis, Imperialism at Bay: The United States and the Decolonization of the British Empire, 1941-1945 (New York: Oxford University Press, 1978), p. 9. The British Empire controlled fifty-five colonies with a combined population of more than sixty million people.

558 Foster Rhea Dulles and Gerald E. Ridinger, "The Anti-Colonial Policies of Franklin D. Roosevelt," Political Science Quarterly, Vol. 70, No. 1 (March, 1955), p. 1.
} 
exploitation. ${ }^{559}$ Roosevelt and the State Department concluded that the liquidation of the colonial system would serve world peace by preventing postwar struggles for independence. However, Roosevelt was a gradualist; he believed that it would take time to wrestle the dependent territories from the colonial powers. Moreover, he understood that independence could be achieved only after a lengthy period of tutelage by a "parent" state. ${ }^{560} \mathrm{He}$ believed it could take as many as twenty years to prepare a dependent population for independence.

In Roosevelt's estimation, a short-term strategy was needed. Cordell Hull, the American secretary of state, proposed that the colonial status quo could be changed by making colonial regimes accountable to an international organization, and by instituting mechanisms for international supervision of the colonial powers' administrations. Roosevelt agreed and proposed to other Great Powers an International Trusteeship System under the aegis of the newly proposed United Nations Organization. According to his proposal, three or four Great Powers would take responsibility for the tutelage and development of trust territories. ${ }^{561}$ This was in keeping with Roosevelt's belief that international security could only be maintained by the four Great Powers - Britain, China, the Soviet Union, and the United States. ${ }^{562}$

\footnotetext{
559 Louis, Imperialism at Bay, p. 4.

560 Robert Dallek, Franklin D. Roosevelt and American Foreign Policy, 1932-1945 (New York: Oxford University Press, 1979), p. 342.

561 Ibid.

562 The Soviets and Americans were hesitant to include France in this role. Stalin believed that France should no longer be considered a Great Power following its ignominious surrender to the Nazis. The Americans, as previously mentioned, also questioned France's Great Power status.
} 
In addition, Roosevelt proposed a system of international inspection and publicity for areas under colonial rule, ${ }^{563}$ thereby "inducing colonial powers to develop their colonies for the good of the dependent peoples themselves and the world." ${ }^{564}$ Following his return from the Teheran and Cairo Conferences in 1943, Roosevelt told a gathering of American journalists that if the "Britishers don't come up to scratch . . . then the United States will let the whole world know." ${ }^{565}$ At the same time, Roosevelt hoped the Trusteeship System would allow the United States to establish air and naval bases at strategic points in the Pacific region. As historian Robert Dallek concluded, "A system of collective rule for the benefit of emerging nations would effectively de-emphasize United States military control. ${ }^{.566}$

The British government wholly rejected the American interpretation of Trusteeship — the development of self-governing institutions and ultimately independence - and the role the new world organization would play in that respect. The British suspected, rightly, that the Americans sought to weaken the British Empire in the postwar period. Churchill was convinced that the Americans were challenging his determination that the "postwar world order would be based on the power, prosperity, and prestige of the British Empire, as it had in the nineteenth century." ${ }^{257}$ Mackenzie King, reflecting on Churchill's unwavering commitment to the British Empire, wrote that

\footnotetext{
${ }^{563}$ Cordell Hull, The Memoirs of Cordell Hull, Vol. 1 (New York: MacMillan Company, 1948), p. 1234.

${ }^{564}$ Dallek, Franklin D. Roosevelt and American Foreign Policy, p. 429.

${ }^{565}$ Dulles and Ridinger, "The Anti-Colonial Policies of Franklin D. Roosevelt," p. 13.

${ }^{566}$ Dallek, Franklin D. Roosevelt and American Foreign Policy, p. 429.

${ }^{567}$ Louis, Imperialism at Bay, p. 5.
} 
it was a religion to him. ${ }^{568}$ Churchill believed that any diminishment of a constituent part of the Empire would weaken the whole and have dire consequences. Therefore, Churchill considered the imposition of the American-style Trusteeship System and international supervision as an outright attack on the British Empire. Churchill saw Trusteeship and international supervision as "merely a cloak of American expansion." 569 At the Teheran Conference of 1943, he made his view clear: "nothing would be taken from England without a war." $" 570$

The British prime minister was not alone in his suspicions. Colonial and Foreign Office officials, and Anthony Eden, the secretary of state for foreign affairs, believed that the “Americans wished to undermine Britain's place in the world in order to establish for themselves an informal empire to pursue their economic interests." ${ }^{571}$ Eden speculated that Roosevelt "hoped that former Colonial territories, once free of their masters, would become politically and economically dependent upon the United States. . . ..572 According to Dallek, British officials were not far off the mark:

Believing that American internationalists would object to the acquisition of postwar air and naval bases for keeping the peace, Roosevelt disguised this plan by proposing that dependent territories come under the control of three or four countries designated by the United Nations. The "trustees"

568 J. W. Pickersgill, (ed.), The Mackenzie King Record: Vol 1, 1939-1944 (Toronto: University of Toronto Press, 1960), p. 679.

${ }^{569}$ Louis, Imperialism at Bay, p. 9.

${ }^{570}$ Richard Toye, Churchill's Empire (New York: Henry Holt and Company, 2010), p. 245.

571 William Bain, Between Anarchy and Society: Trusteeship and the Obligations of Power (London: Oxford University Press, 2003), p. 114.

572 Anthony Eden, The Eden Memoirs: The Reckoning (London: Cassell and Company, 1965), p. 513. Also see: Raymond Daniell, "New British Colonial Policy Forged by War," New York Times, March 22, 1942, p. E3. Daniell reported that the "granting of bases to the United States in the West Indies, it is believed here [London], is bound eventually to weaken their tie to the old country and direct their eyes more and more to the United States than to Britain for her protection ...." 
were to assume civil and military responsibilities for the dependent peoples until they were ready for self-rule. In this way, the United States would both secure strategic bases and assure self-determination for emerging nations around the globe. ${ }^{573}$

The Anglo-American wartime disagreements over colonialism set the context for many of MacCallum's apprehensions about the development of a postwar Trusteeship System. From the time she joined the department in 1942, she had seen in her work two impulses emanating from the United States and Great Britain: American press criticisms of British colonialism and imperialism, and British efforts to enlist Canada's support for British colonial policies. Tasked with collating and summarizing weekly media reports on the Allies' war effort for the prime minister, ${ }^{574}$ MacCallum was aware of the animosity emanating from the American press towards the British Empire in general, and British imperialism in particular. While the resentment towards the British Empire had always been an underlying characteristic of the Anglo-American relationship, it was more pronounced following the 1942 defeat of British forces in South-East Asia. As a result of their humiliating defeat at Singapore, Malaya, and Burma, the British were ridiculed in the American press not merely as imperialists, but as bungling imperialists, according to Neville Butler, a minister at the Foreign Office. ${ }^{575}$ Life and Fortune magazines attacked

\footnotetext{
573 Dallek, Franklin D. Roosevelt and American Foreign Policy, p. 537.

574 K.A. McCloskey, "Memorandum to the Civil Service Commission from the Department of External Affairs," July 9, 1942, Civil Service Commission Papers, LAC, RG 32, Vol. 451, File: Elizabeth Pauline MacCallum. As previously noted, in 1942 MacCallum duties included: preparing briefs for the prime minister's attention on current and international affairs; the review and interpretation of current and international affairs for foreign service officers in the department, using the "most secret documents" and information supplied from officers abroad; and extracting from newspapers and periodicals.

575 J. E. Williams, "The Joint Declaration on the Colonies: An Issue of Anglo-American Relations, 194244," British Journal of International Studies, Vol. 3, No. 3 (October, 1976), p. 268.
} 
British imperial policy and found no justification for the continued existence of the British colonial system, especially in the Western Pacific and South-East Asia. ${ }^{576}$

These attacks, which continued throughout the war, did not go unnoticed in Canada. G. H. Lash, the director of the bureau of public information in Canada, cautioned the national press about criticizing Canada's wartime partners. In addressing the issue, Lash urged them to:

[S]et an example in unity that our partners must follow. Look about you and what do you find? "Doubt of the courage of American naval men voiced in Canada: American papers and speakers hammering at British policy and British leadership until today." British prestige is lower in the U. S. than it has been within memory of any of us. ${ }^{577}$

Britain attempted to enlist the support of Canadian officials in mollifying the anticolonial and anti-British feeling in America. ${ }^{578}$ London suspected that the anti-colonial sentiment would force Roosevelt to take a hard line on British colonial policies. This conjecture was reported by Richard Law, the parliamentary under-secretary of state for foreign affairs. "The Roosevelt Administration," observed Law, "cannot go further than its public opinion will allow ...." 579 The Foreign Office also feared that, unless the American mood toward the British was contained and properly managed, domestic pressures in the United States would push Roosevelt to alter the balance of his force

\footnotetext{
576 Ibid.

577 “Criticize Canadians Who Belittle Allies, Toronto Star, March 12, 1942, p. 34.

${ }^{578}$ Hume Wrong, "Memorandum to Under-Secretary of State for External Affairs," December 14, 1942, in DCER, Vol. 9, 1942-1943, p. 1001. Wrong told Robertson that he "agreed that it is a matter of considerable importance to deal with the criticism rampant in the United States of British Colonial policy." Also see: J. R. Baldwin, December 15, 1942, in Documents on Canadian External Relations (DCER), Vol. 9, p. 1003.

579 Anthony Eden, "Mr. Richard Law's Visit to the United States," October 26, 1942, The National Archives (TNA), War Cabinet Papers, W.P., Vol. 42, No. 492, p. 8.
} 
distribution between the Far Eastern and European theatres of war, or demand an immediate commitment to dismantle the British Colonial System before further American forces were committed to the defence of British territories. ${ }^{580}$

The British wasted little time following Law's report in approaching the Canadian prime minister and External Affairs. Lord Cranborne, the secretary of state for dominion affairs, asked Mackenzie King for his comments on a proposed memorandum to be sent to the Roosevelt administration. ${ }^{581}$ In referring to the widespread American criticism regarding the British Empire, Cranborne stated that it was: "essential that we should act now to convince United States opinion that our colonial policy is not a danger and an anachronism as certain quarters in that country are inclined to regard it." ${ }^{\circ 82}$ Cranborne proposed to the Canadian prime minister a plan that would seek America's military assistance in defending the Empire's colonial territories. The plan further proposed the creation of regional colonial commissions, comprised of Great Powers and other powers, which would guide and develop the social and political institutions of the territories with which they were concerned. The plan would also ensure that the natural resources of the territory were properly organized and marketed not for the promotion merely of commercial ends, but in the best interests of the peoples concerned and of the world as a whole.

\footnotetext{
${ }^{580} \mathrm{Ibid}, \mathrm{p} .9$.

${ }^{581}$ Lord Cranborne, "Dominions Secretary to Secretary of State for External Affairs," December 11, 1942, in DCER, 1942-1943, Vol. 9, pp. 998-1000. Similar telegrams were sent to the Governments of Australia, New Zealand, and South Africa.

582 Ibid.
} 
The importance and intent of the British dispatch was not lost on External Affairs officials or the prime minister. The British wanted Canada to support a revamped colonial policy, thereby backing London in its dispute with Washington. In accordance with Britain's request for a timely response to Cranborne's memorandum, ${ }^{583}$ the proposal was reviewed by the Department of External Affairs, officials of the Privy Council Office (PCO), the Bank of Canada's Foreign Exchange Control Board, and the Prime Minister's Office (PMO) ${ }^{584}$ These departments were unanimously critical of the British scheme. Some of the Canadian officials, such as Louis Rasminsky of the Bank of Canada, suggested that the British scheme was largely an effort to roll back the League's Mandates System and allow the colonial powers free rein over dependent territories. ${ }^{585}$ More importantly, he saw the plan as only exacerbating Anglo-American tensions. ${ }^{586}$ "If the British put up this proposition which is unimaginative and unprogressive," contended Rasminsky, "not only will no good be accomplished, but positive harm. For the critics, including the friendly critics, of British policy will find in such a proposition confirmation of their suspicions and fears." 587 J. R. Baldwin of the PCO echoed Rasminsky's apprehensions. He regarded the British proposal as a reactionary initiative

\footnotetext{
583 Norman Robertson, "Memorandum from Under-Secretary of State for External Affairs to Prime Minister," December 16, 1942, in DCER, Vol. 9, p. 1008.

${ }^{584}$ For a further explanation of Ottawa's response to British memorandum D. 538, see: Vincent Massey, "High Commissioner in Great Britain to Secretary of State for External Affairs," December 12, 1942, in DCER, Vol. 9, pp. 1000-1001; Hume Wrong, "Memorandum to Under-Secretary of State for External Affairs," December 14, 1942, in DCER, Vol. 9, pp. 1001-1003; J. R. Baldwin, "Privy Council Office to Secretary to the Cabinet," December 15, 1942, in DCER, Vol. 9, pp. 1003; Louis Rasminsky, "Alternate Chairman, Foreign Exchange Board, to Assistant Under-Secretary of State for External Affairs," December 15, 1942, in DCER, Vol. 9, pp. 1004-1005.

${ }^{585}$ Rasminsky, "Alternate Chairman, Foreign Exchange Board, to Assistant Under-Secretary of State for External Affairs," p. 1005.

${ }^{586}$ Ibid

${ }^{587}$ Ibid, pp. 1004-1005.
} 
that attempted to gut the limited safeguards built into the League's Covenant. ${ }^{588}$ Specifically, it would eliminate the Permanent Mandates Commission and replace it with a Regional Commission managed by the colonial powers. Baldwin also saw the dangers that the scheme posed for the wartime alliance. The plan "would appear to be largely a justification of British policy in the past, and would indicate no major change in that policy. This would not help matters, since the existing criticism is largely based on past British policy." 589

Reviewing the British memorandum in a broader context, officials in External Affairs were convinced that the British initiative represented a dangerous turn in AngloAmerican relations, especially at such a critical time in the Allied war effort. The undersecretary was particularly concerned about the impact Britain's unwavering commitment to its Empire would have on American public opinion, and to a lesser degree, on Canadian public attitudes. Robertson cautioned the prime minister that the British proposal would only increase Americans' suspicions of and contempt for Britain's wartime aims, and present serious problems for future Anglo-American relations. ${ }^{590}$

In his December 23, 1942 response to Lord Cranborne, ${ }^{591}$ Mackenzie King chose not to raise Robertson's principal objection, which was to criticize the substance of the

\footnotetext{
${ }^{588}$ Baldwin, "Privy Council Office to Secretary to the Cabinet," p. 1003.

589 Ibid.

${ }^{590}$ Norman Robertson, "Memorandum for the Prime Minister," in DCER, Vol. 9, p. 1007.

${ }^{591}$ Mackenzie King, "Secretary of State for External Affairs to Dominions Secretary,” December 23, 1942, in DCER, Vol. 9, p. 1009.
} 
proposed plan for future British colonial policy, and how the plan should be developed. ${ }^{592}$ Instead, he talked of the public debate that would inevitably arise over such a contentious issue. He believed the war years were neither the proper time nor occasion for such a debate. It would only inflame Anglo-American differences over colonialism and intensify the growing anti-British sentiment in the United States, declared King. With one eye on the world, and one on Canada, King confessed to Cranborne "the criticisms of British colonial policy found in the United States [were] also present to some degree in Canada."

By using an American lens, King gently guided his critique into a call upon the British to internationalize colonial policy, place greater emphasis on the rights of indigenous peoples, renew or clarify their commitment to the Atlantic Charter, and downplay the plan's emphasis on the United States defence of colonial territories. ${ }^{594}$ In doing so, King hoped to sidestep the question of where Canada's support lay. The prime minister undoubtedly believed that his reply to Cranborne had enabled him to retain room to maneuver and to influence British officials. However, the Foreign Office drew very different conclusions from the prime minister's response. According to J. E. Williams, the British believed that the Canadians were on board. They had approved — with minor

\footnotetext{
592 Robertson, “Memorandum for the Prime Minister,” in DCER, Vol. 9, p. 1007.

${ }^{593}$ King, "Secretary of State for External Affairs to Dominions Secretary," p. 1009. 594 Ibid.
} 
changes - Britain's blueprint for the development of a new and more robust colonial policy, devoid of the encumbrances of supervision..$^{595}$

The under-secretary's warnings to the prime minister accurately predicted the Anglo-American difficulties to come. From their opposing perspectives, Roosevelt and Churchill had decided to try to steer a course away from any formal discussions of the postwar Trusteeship System until the San Francisco Conference. ${ }^{596}$ This was particularly evident when the U. S. secretary of state decided to have "Chapter 11: Arrangements for Territorial Trusteeships" ${ }^{\prime 597}$ removed from the Americans' draft proposal for the new international organization at the Dumbarton Oaks Conference in 1944. Frustrated by the impasse, both Roosevelt and Churchill agreed to allow their delegations to try to find a way out of their differences. ${ }^{598}$ In late December 1944, the British delegation, following the end of the Dumbarton Oaks Conference, presented the American delegation with a memorandum entitled: "International Aspects of Colonial Policy." 599 Once again, the British attempted to change the Roosevelt administration's anti-colonial mindset. ${ }^{600}$ In doing so, they tried to enlist Canadian officials in their efforts. To the chagrin of British officials, the Canadians refused to be drawn into the quarrel. The prime minister voiced

\footnotetext{
${ }^{595}$ Williams, "Joint Declaration on the Colonies," p. 279.

${ }^{596}$ Brian Urquhart, Ralph Bunche: An American Odyssey (New York: W. W. Norton \& Co., 1998), p. 112.

597 "United States Tentative Proposals for a General International Organization," July 18, 1944, in FRUS, Vol. 1 (Washington D. C.: Government Printing Office, 1966), p. 665, footnote 22.

${ }^{598}$ George Ignatieff, “Territorial Trusteeship,” March 21, 1945, External Affairs Records, LAC, RG 25, Vol. 1021, File: 6-F, p. 1. The British working paper was forwarded to Ottawa and the other Dominions on December 27, 1944 for review.

${ }^{599}$ Ibid. Also see: Lester Pearson, Mike: The Memoirs of the Right Honourable Lester B. Pearson, Vol 2, 1948-1957 (Toronto: University of Toronto Press, 1973), p. 269. Also, see: "New Zealand's Part in the Establishment of an International Security Organization," Part II: International Trusteeship, p. 93, [Unpublished Manuscript], Hillmer Papers.

${ }^{600}$ Louis, Imperialism at Bay, p. 392.
} 
his unwillingness to comment on questions of colonial policy because Canada controlled no dependent territories. ${ }^{601}$

With only weeks left before the commencement of the San Francisco Conference, the British government tried to coax the Dominions to support their position. In accordance with the British promise to brief Commonwealth leaders on the outcome of the Crimea and Dumbarton Oaks Conferences, British officials from the Colonial and Foreign Offices met with Dominion representatives in London in early April 1945. The British, suggested John Holmes, viewed the gathering, as little more than a "“dress rehearsal for San Francisco." ${ }^{602}$ Taking the lead, Lord Cranborne and Lord Stanley, secretary of state for the colonies, forcefully defended the British prime minister's determination to repulse any American effort to alter the Mandate System, which Churchill believed would dilute the status and legitimacy of the British Empire's Colonial System. Cranborne and Stanley insisted that the only way forward must lay in the roadmap articulated in the modified version of "International Aspects of Colonial Policy," the guiding principle of which was to avoid international supervision of Britain's colonial and mandated territories. The British pronouncement set off a heated response from Australia's, New Zealand's, and India's representatives.

The Canadians tried to contain the dispute. Represented by Vincent Massey, Canadian high commissioner to London, and Hume Wrong, the associate under-secretary of state for external affairs, the Canadians encouraged British officials to harmonize their

\footnotetext{
${ }^{601}$ Ignatieff, "Territorial Trusteeship,” pp. 1-2.

${ }^{602}$ Holmes, The Shaping of Peace, Vol. 1, p. 244.
} 
colonial policy with that of the United States. ${ }^{603}$ Wrong suggested that, if Britain's imperial policies were not moderated, the British government risked further alienating American public opinion and the country's policymakers. He cautioned his British hosts that it would be equally dangerous if they attempted to remove the colonial question from the San Francisco agenda. "Any attempt to 'muzzle' discussion of the colonial question at San Francisco," urged Wrong, "would antagonize Americans otherwise friendly to the Commonwealth."604

After considering Canada's conciliatory attitude, and fearing a profound split with the other Commonwealth countries, Lords Stanley and Cranborne softened their stance on Trusteeship. As a trade-off, the British agreed to maintain mechanisms used by the Permanent Mandates Commissions for supervision of the mandated territory. In exchange, they refused to allow international accountability to go beyond the League of Nations' provisions. ${ }^{605}$ In other words, they would not accept any additional powers for the proposed Trusteeship Council. By the end of the meetings, it was clear that Britain had failed to establish its much-needed united front. On the contrary, the sharp differences that had been expressed in London made British officials realize that their desire to establish unanimity on colonialism at the San Francisco Conference was

\footnotetext{
${ }^{603}$ Holmes, The Shaping of the Peace, Vol. 2, p. 22.

${ }^{604}$ Louis, Imperialism at Bay, p. 508.

605 Ibid, p. 504.
} 
unattainable. The resulting divisions, wrote imperial historian Wm. Roger Louis, "cracked the façade of the Commonwealth."606

With Wrong's return to Ottawa carrying news that there were clear-cut divisions over Trusteeship and colonial policy in the Commonwealth, MacCallum's opinion that Canada's intended course for San Francisco was a miscalculation had been strengthened. Privy to the correspondence exposing Britain's wartime proposals, MacCallum could see that Canada was avoiding the question of colonial policy whenever possible, that Britain was determined to involve Canadian officials in the Anglo-American rift, and that the United States believed that the British White Paper of 1939 was illegal. ${ }^{607}$ She must have felt that a strong and clearly-defined Canadian policy on colonialism and Trusteeship was desperately required, and it is clear what she thought that policy should be. Nevertheless, there were larger issues at stake, going to the future direction of the Empire and the Commonwealth. Was it to be a Commonwealth based on Churchill's Victorian notion of Empire? Or would the traditional Canadian view of Empire — as a decentralized institution - prevail?

There is little doubt, based on MacCallum's interwar writings, that she favoured a fundamentally different approach to Trusteeship and a new mechanism for international stewardship. Firmly opposed to the Canadian view that the Great Powers should have the exclusive right to construct the postwar Trusteeship System, MacCallum believed that it was the collective responsibility of all member nations of the new organization to erect a

\footnotetext{
${ }^{606}$ Ibid, p. 511.

607 “Minutes of 56th Meeting of the U. S. Delegation,” May 28, 1945, in FRUS, General, Vol. 1, p. 950.
} 
more just system for the management and supervision of dependent territories. If Great Power privilege over Trusteeship continued, it would ensure continued inequalities between nations, unrelenting unrest in the Middle East, and an ever-increasing instability in the international system. MacCallum saw no evidence that the colonial and Great Powers had changed their attitude in the direction of a more equitable system of administering dependent territories.

MacCallum believed that solving the Palestine problem was essential to successful deliberations on the Trusteeship System. It was, to her, an unavoidable issue for the conference and the Canadian delegation. When the transfer of the remaining Mandates of the League of Nations to the United Nations came up for discussion, she believed that the Arab and Zionist forces, inside and outside the Trusteeship Committee, would push the Conference to take up the issue, at least indirectly. Based on what she had seen from the Zionist campaign in Canada, and the news reports emanating from the United States over the last two years, MacCallum must have believed that both party's uncompromising positions would pose a threat to the Conference's efforts to draft a blueprint for Trusteeship.

\section{The Working Paper on Trusteeship}

In accordance with the principles and purposes set forth by the Great Powers in the Proposals for the Establishment of a General International Organization, ${ }^{608}$ the Conference's Steering Committee officially organized the proceedings into twelve

\footnotetext{
${ }^{608}$ Woodrow Wilson Foundation, Proposals for the Establishment of a General International Organization, as submitted by the Dumbarton Oaks Conference, October 9, 1944 (New York: The Woodrow Wilson Foundation, 1944), pp. 1-12.
} 
technical Committees. ${ }^{609}$ Each committee specialized in a particular element of the organization's Charter.

The discussion of and responsibility for International Trusteeship fell to Committee II, which subsequently established Committee IV, a technical committee to study the principles and machinery for Trusteeship. Huntington Gilchrist, a former member of the international secretariat of the League of Nations, described Committee IV as the showpiece of the Conference. The committee had a "large and steady audience of delegates, advisers, members of the United Nations' Secretariat, and it met in the largest of the Committee rooms." 610 Added to the drama was the fact that, unlike the other conference committees, which had the Dumbarton Oaks proposals as the framework for their discussions, the Trusteeship Committee had no certain direction since Trusteeship had been omitted from the Dumbarton discussions. ${ }^{611}$ The committee, at best, could answer many of the pressing colonial questions, and address the issue of Palestine; at the very least, it could attempt to create a framework for fairness and justice.

However, it was not long after Committee IV's work began that MacCallum's doubts about Canada's approach, and the problems inherent in it, were illuminated. As she had anticipated, Trusteeship's operating principles and machinery were destined to be

${ }^{609}$ Ruth B. Russell and Jeannette E. Muther, A History of the United Nations Charter: The Role of the United States, 1940-1945 (Washington, D.C.: Brookings Institute, 1958), p. 640. The Steering Committee was composed of the chairperson and representatives from all of the delegations. The Steering Committee directed the Conference and dealt with questions of major policy or procedure submitted to it by the president or the chairperson of any delegation.

${ }^{610}$ Gilchrist, "V. Colonial Questions at San Francisco Conference," p. 984.

${ }^{611}$ Canada, Report on the United Nations Conference on International Organization, 49. Trusteeship was referred to a Five-Power Consultative Group scheduled to meet prior to San Francisco Conference. However, because of time constraints, the meetings were held concurrently with the Conference. 
dictated by the Great Powers, and the promise of Great Power collaboration to advance the interests of all dependent peoples would soon be abandoned as competing strategic interests dominated deliberations and proposals. Beginning on April 30th, in the drawing room of the Fairmont hotel's penthouse, the Great Powers met over the course of nine weeks to hammer out an agreement on Trusteeship. Initially, the meetings were only attended by the Conference's four sponsoring powers - Britain, China, Russia, and the United States. However, after several days of debate in which delegates pondered whether France should be included in the deliberations, it was decided to invite France to join a Five-Power Consultative Group. ${ }^{612}$ With Edward Stettinius Jr. as the presiding officer, the group decided that it would attempt to work out a joint proposal that would form the basis of discussion in Committee IV. ${ }^{613}$ They also agreed that no changes could be made to their final Trusteeship proposal without the unanimous agreement of the group. The smaller powers immediately understood the implications of this arrangement; they would not be able to make any change to a Great Power proposal without Great Power consent. ${ }^{614}$

At the preliminary meeting on April 30, 1945, Commander Harold Stassen, the chairperson of the consultative group, presented the U. S. draft proposal on Trusteeship and called for a recess so the other delegations could review the American plan. ${ }^{615}$ The

\footnotetext{
${ }^{612}$ Russell and Muther, A History of the United Nations Charter, p. 808, footnote 1. Representing the five powers were: V. K. Wellington Koo (China), Paul-Emile Naggiar (France), Viscount Cranborne (Great Britain, A. A. Sobolev (Soviet Union), and Commander Harold Stassen (United States).

${ }^{613}$ Ibid.

${ }^{614}$ Gildersleeve, Many a Good Crusade, p. 337.

615 "Minutes of the Twenty-third Meeting of the United States Delegation," April 30, 1945, in FRUS, 1945, Vol. 1, p. 491.
} 
American draft proposal for Trusteeship, referred to as the "Working Paper for a Chapter on Dependent Territories and Arrangements for International Trusteeship" (the Working Paper), was more than three years in the making and the product of countless iterations beginning with the draft of the Atlantic Charter of 1941, and ending with the U. S. Interdepartmental Committee's draft document on dependent areas in mid-March 1945. ${ }^{616}$ The document's central goal was to establish minimum political, economic, and social standards that would be applied to all dependent territories, whether they were Mandates, protectorates, colonies, or trust territories. The paper's core principles assumed that the fate of dependent peoples and their territories were the proper concern of the international community as a whole, and that states responsible for such dependencies must be held accountable for their administration. Therefore, the American plan called for a Trusteeship committee that had the authority to "consider reports submitted by the administering authority, to accept petitions, to institute investigations, and to take other action within their competence as defined by the Trusteeship arrangements." ${ }^{\prime 617}$ Lastly, the Working Paper called for the establishment of strategic and non-strategic trust areas. "All functions of the Organization relating to strategic areas, including the approval of the Trusteeship arrangements and their alteration or amendment, should be exercised by the Security Council," concluded Stassen.

\footnotetext{
${ }^{616}$ Russell and Muther, A History of the United Nations Charter, p. 576.

${ }^{617}$ Ibid, “Appendix K: Arrangements for International Trusteeship,” pp. 1030-1031.
} 
The Working Paper was seen by Britain and France as a self-righteous and hypocritical document, reported MacCallum's colleague, Gerry Riddell. ${ }^{618}$ When informed of the American proposal, and particularly the provisions pertaining to strategic trusts, Lord Stanley telegraphed Cranborne and insisted that the American plan was "unacceptable." Stanley was angered by "the U. S. effort to foist Trusteeship upon the Conference and then seek to escape its obligations by designating their territory as strategic." ${ }^{619}$ Cranborne's military aide, Brigadier-General Ian Jacob, declared that the American strategic proposal was merely a means to escape "the odium of becoming classified as an imperialist power." 620

As for the exercise of authority over Trusteeship, Stanley was unwilling to accept the guidance of future United Nations General Assembly member states because he believed that the Assembly would push for increased international accountability and intervention. ${ }^{621}$ France was equally suspicious about the proposed Trusteeship machinery. As political scientist Kenneth Twitchett stated, the French suspected that Trusteeship "would result in interference in what [France] considered to be purely domestic matters."622 The American proposal had evidently disregarded France's previous assertions that Trusteeship could not exceed the framework established by the League of Nations Mandate system. Paris believed that, without the consent of the Mandatory

\footnotetext{
618 Gerry Riddell, "Minutes of Canadian Delegation Meeting," May 18, 1945, External Affairs Records, LAC, RG 25, Vol. 1021, File: 6-F, p. 2.

${ }^{619}$ Louis, Imperialism at Bay, p. 524.

${ }^{620}$ Ibid, p. 523.

621 Ibid.

${ }^{622}$ Kenneth J. Twitchett, "The Colonial Powers and the United Nations," Journal of Contemporary History, Vol. 4, No. 1, Colonialism and Decolonialism (January, 1969), p. 177.
} 
powers, the new Trusteeship System only applied to Japanese possessions in the Pacific and Italian possessions in Africa. The French made it quite clear that they would not permit an expanded framework for Trusteeship.

On May 3rd, the Consultative Group reconvened. Following a lengthy discussion of the American proposal, Cranborne presented Britain's proposal for Trusteeship. ${ }^{623}$ In contrast to the Americans' vision, the British presented a flimsy draft designed to counteract the American proposal. ${ }^{624}$ The American political scientist, Ernst Haas, characterized the British plan as "a mixture of conservative humanitarian, economic and strategic motivations in the effort to minimize international control." ${ }^{625}$ The British submission declared that the general principles for the administration of dependent peoples should not exceed the line laid down in Article 22 of the League of Nations' Covenant. Moreover, Cranborne stressed that the achievement of self-government, rather than independence, should be the primary goal of both the trust authority and the nonself-governing territories. ${ }^{626}$ Like the French and the Dutch delegations, British officials believed that independence should naturally evolve, not be imposed by an international forum. ${ }^{627}$

\footnotetext{
623 See: United Nations Information Organization, Documents of the United Nations Conference on International Organization, Vol. 3, p. 609.

${ }^{624}$ Brian Urquhart, Ralph Bunche: An American Life (New York: W. W. Norton \& Company, 1993), p. 119.

${ }^{625}$ Ernst Haas, "The Attempt to Terminate Colonialism: Acceptance of the United Nations Trusteeship System," International Organization, Vol. 7, No. 1 (February, 1953), p. 16.

626 Twitchett, "The Colonial Powers and the United Nations," p. 177.

${ }^{627}$ Haas, "The Attempt to Terminate Colonialism," p. 17.
} 
In contrast to the American military and strategic recommendations, the British proposal rejected the need for strategic and non-strategic trusts. ${ }^{628}$ The British pointed out that the restrictions imposed on strategic trust territories would deny indigenous inhabitants international supervision on social and economic problems. ${ }^{629}$ The British also questioned how large Mandated territories could be partitioned into strategic and non-strategic territories. Instead of strategic trusts, Cranborne recommended a "general provision affecting security matters which would make it possible to use resources and facilities in any territory for purposes of security and local defense." ${ }^{630}$ In other words, the British sought the right to conscript forces and establish military facilities in any trust or colonial territory. Cranborne subsequently proposed that the responsibilities for trusts should reside with the United Nations Social and Economic Council instead of with the General Assembly. On the matter of non-discriminatory policy, the British opposed the American call for an "open door" commercial policy in mandated areas and on strategic bases. ${ }^{631}$ The British instead held that trade should be left to the trustee to decide whether such a policy was in the interests of the dependent territory. ${ }^{632}$ Stassen rejected Britain's proposal outright. He insisted that:

\footnotetext{
628 "Minutes of Thirty-Fourth Meeting of the United States Delegation," May 9, 1945, in FRUS, 1945, Vol. 1, p. 656.

629 United Nations Information Organization, Documents of the United Nations Conference on International Organization, Vol. 10, pp. 678-680.

630 "Minutes of Thirty-Seventh Meeting of the United States Delegation," May 12, 1945, in FRUS, 1945, Vol. 1, p. 686.

631 "Minutes of Thirty-Fourth Meeting of the United States Delegation," May 9, 1945, in FRUS, 1945, Vol. 1, p. 656.

${ }^{632}$ D. K., "The Trusteeship Proposals at San Francisco," The World Today, Vol. 1, No. 2 (August, 1945), p. 83.
} 
It was weaker than ours, there was no spelling out, and there was no division of strategic and nonstrategic areas. Moreover, it did not include a clear statement of objectives and the British placed the Trusteeship Council as a commission under the economic and social Council. ${ }^{633}$

Following Britain's exchange with the U. S. over strategic trusts and international accountability, the Chinese and Soviet representatives joined the fray. They questioned the objectives of Trusteeship and the supervising machinery for the Trusteeship System. The Soviet delegate, A. A. Sobolev, insisted that the objective of Trusteeship must be independence. While Stalin saw the United Nations as largely insignificant, ${ }^{634}$ he used the divisions among the Western powers over the question of independence to undermine the entire basis of colonialism, and present the Soviets as the sole protector of the defenseless peoples now under capitalist domination. ${ }^{635}$ As for the Mandate System, Stalin believed it was little more than a "bourgeois" interwar arrangement.

Cranborne argued strongly against the inclusion of the word independence. ${ }^{636}$ The French supported the British in opposing any effort to diminish the authority of the colonial powers, dismantle the colonial system, or, at the very least, to put it under the United Nations' authority. ${ }^{637}$ On the issue of international supervision, Britain and France wanted an expert commission, similar to the League of Nations Permanent Mandates

\footnotetext{
633 "Minutes of the Twenty-Ninth Meeting of the United States Delegation," May 4, 1945, in FRUS, 1945, Vol. 1, p. 597.

${ }^{634}$ Dallin, The Soviet Union and the United Nations, pp. 24-25. According to Dallin, "Stalin's hopes for the postwar world - and for his own power position in it - lay outside the future world organization."

${ }^{635}$ Gerry Riddell, "Minutes of Canadian Delegation Meeting," May 18, 1945, External Affairs Records, LAC, RG 25, Vol. 1021, File: 6-F, p. 2.

636 "Minutes of the Fourth Four-Power Consultative Meeting on Charter Proposals," May 4, 1945, in FRUS, 1945, Vol. 1, pp. 601-602.

637 "Minutes of the Thirty-Fourth Meeting of the United States Delegation," May 9, 1945, in FRUS, 1945, Vol. 1, p. 656.
} 
Commission, which would inform the General Assembly through the Economic and Social Council whether the terms of the Trusteeship agreement were being met. ${ }^{638}$ The United States, on the other hand, believed that, given the fact that the issues involved would require dealing with governments, a high-level organization was necessary. Therefore, the Trusteeship Council should "logically report directly to the Assembly."639 The Soviets added that Security Council members should be permanent members of the Council, presumably being able to use their veto.

It was clear to Cranborne, Britain's point person on colonial policy at the San Francisco Conference, that an anti-colonial block, or more specifically, an anti-British movement, composed of China, the Soviet Union, the United States, the Latin American states, and quite possibly some of the Commonwealth Dominions, was rapidly emerging. It appeared to him that their goal was quite possibly to isolate the British if they did not capitulate on Trusteeship. ${ }^{640}$ In a note to the War Cabinet, Cranborne cautioned that this anti-colonial block could outvote Britain and force it and the colonial powers to accept a more radical Trusteeship scheme, one that could cripple or even end the colonial system. ${ }^{641}$ This would leave Britain little choice, thought Cranborne: Britain would be forced either to accept the findings of the Committee or refuse to sign the Charter. To circumvent this potential crisis, Cranborne recommended to the War Cabinet that Britain act quickly and bring its colonial policy in alignment with America's Trusteeship plan.

\footnotetext{
${ }^{638}$ Russell and Muther, A History of the United Nations Charter, pp. 838-839.

${ }^{639}$ Ibid, p. 839.

${ }^{640}$ Louis, Imperialism at Bay, p. 525.

${ }^{641}$ H. V. Evatt, the Australian minister of external affairs, proposed on May 10, 1945 that all colonial powers should be forced to turn over all of their Colonial territories to the United Nations Organization.
} 
This meant finding accommodations that would not imperil the British Empire's strategic interests. $^{642}$

On May 14, 1945, Churchill and his War Cabinet concurred with Cranborne's assessment and authorized the British delegation immediately to bring their proposals in line with the American plan. This resulted in an Anglo-American compromise on the contentious issues of strategic trusts, commercial policy, and self-determination. They agreed, in short, to fuse their plans for Trusteeship. By late afternoon of May 19th, a draft of the Anglo-American plan for Trusteeship was completed. It addressed both countries' core interests. The following day Stassen submitted the plan to Committee IV. ${ }^{643}$ The amended American document was submitted in two parts, owing to some still unresolved differences regarding the composition of the Trusteeship Council, powers of inspection, visits, and petitions. ${ }^{644}$ Part A presented a broad statement of the principles for the new organization's Trusteeship System, and Part B laid out the mechanisms and objectives for governing Trusteeship. ${ }^{645}$

\footnotetext{
642 "Minutes of the Forty-Fifth Meeting of the United States Delegation," May 18, 1945, in FRUS, 1945, Vol. 1, p. 794. Stassen pointed out during the meeting that the United States "did not wish to find ourselves committed to breaking up the British Empire." More importantly, he affirmed Cranborne's assessment that, if the U. S. sided with China and the Soviet Union, there would be no Trusteeship system since Britain would refuse to sign the Charter. Therefore, without Britain, there would be no Trusteeship. They would take their mandated territories with them.

${ }^{643}$ Gilchrist, "V. Colonial Questions at the San Francisco Conference," p. 985.

644 "Minutes of the Fifty-Fourth Meeting of the United States Delegation," May 26, 1945, in FRUS, 1945, Vol. 1, p. 925.

${ }^{645}$ Gilchrist, "V. Colonial Questions at the San Francisco Conference," p. 985. On May 25, 1945, after much discussion and negotiation, Australia's proposal was presented to the Committee as Part C of the American Working Paper.
} 
On June 20, 1945, on behalf of Committee IV, Chairman Peter Fraser announced the adoption of the amended American Working Paper. ${ }^{646}$ Of the eventual nineteen chapters that made up the United Nations Charter, Trusteeship, following directly the wording adopted by Committee IV, would occupy three: Chapter 11: Declaration Regarding Non-Self-Governing Territories; Chapter 12: International Trusteeship System; and Chapter 13: The Trusteeship Council. To many delegates, the Trusteeship System thus established was San Francisco's crowning achievement. Jan Christian Smuts, the prime minister of the Union of South Africa and valued advisor to Churchill, acclaimed it as "“one of the most important pieces of work that had been done at this Conference." $" 647$

However, for MacCallum, the Trusteeship deal was far from a landmark achievement in international relations. Her apprehensions about the Great Powers' intent and the developing Great Power cleavages were surely justified after she studied the amended American draft proposal, and the other Great Power submissions. ${ }^{648}$ She had in the past exhaustively studied instances of Great Power international administration, and judged them to be flawed. In her 1926 study, "The Internationalization of Tangier," she insisted that "the record of international administration . . . had been one of notorious inefficiency."649 It was a device to maintain the status quo when Great Powers had

\footnotetext{
646 Ibid.

${ }^{647}$ Urquhart, Ralph Bunche: An American Odyssey, p. 120.

648 Ibid. Australia's, France's, and the United States' draft proposals were published as Conference documents on May 5, 1945. The following day, Britain's proposal was published.

${ }^{649}$ Elizabeth MacCallum, "The International Problem of Tangier," Foreign Policy Association Information Service (FPAIS), September 29, 1926, Vol. 2, No. 15, p. 170.
} 
competing interests in a given area. MacCallum reasoned that the "governing body was accountable for its official acts not to the citizens ... but to a number of more or less distant European governments." ${ }^{650}$ International Trusteeship, she concluded, "rested on too many shoulders; none was vested with sufficient power to put vitality into administration." $" 651$

An assessment of the Working Paper would have led MacCallum to reach a similar conclusion. In general terms, she would have seen Part A's declaration as little more than a compromise between the United States and Great Britain, which allowed the colonial empires to remain safely removed from international supervision and interference. The United States, in return, received guarantees that an "open door" commercial policy for those territories would be affirmed; more importantly, the acceptance of strategic trusts enabled the United States military to annex and arm territories without interference from the General Assembly. ${ }^{652}$

MacCallum was undoubtedly struck by the language and intent of Part A's declaration. ${ }^{653}$ The amended Working Paper would have had an all too familiar tone to it. Part A's general declaration was remarkably similar to Article 22 of the League of

${ }^{650}$ Ibid, p. 171.

${ }^{651}$ Ibid.

${ }^{652}$ Secretary of State, Charter of the United Nations: Report to the President (Washington, D.C.: Department of State, 1945), see: Article 82 and 83, p. 198.

653 "Chapter 11: Declaration Regarding Non-Self-Governing Territories," The Charter of the United Nations, p. 194. Article 73 declared that the primary objective of all members of the United Nations which have or "assume responsibilities for the administration of territories whose people have not yet attained a full measure of self-government recognize the principle that the interests of the inhabitants of these territories are paramount, and accept as a sacred trust the obligation to promote to the utmost, within the system of international peace and security established by the present Charter, the well-being of the inhabitants of these territories ...." 
Nations' Covenant. ${ }^{654}$ It was the offspring of the same parents. The declaration reflected the Colonial Powers' interwar tradition of "Imperial Trusteeship," emphasis on protecting empires and ensuring rapid economic development of a territory for the empire's advantage. ${ }^{656}$ It was obvious that the Great Powers were unwilling to cede power to the United Nations in order to investigate complaints, punish administering countries for failing to live up to their international responsibilities, or in the worst case, to strip a trust power of its authority over a dependent territory. Instead, the wording of paragraph one, "On General Policy," the statement of principles, only obligated the Great Powers to "recognize the interests of the inhabitant" and "accept as a sacred trust the obligation to promote ... the well-being of the inhabitants of the territories." ${ }^{967}$ MacCallum unquestionably saw in this provision, as she had in Article 22 of the League's Covenant, as an empty affirmation, failing to invest the General Assembly with any substantive enforcement mechanisms or suitable machinery for bringing offenders promptly before the Trusteeship Council.

Nor were there embodied in the Charter methods for assessing and ensuring the timely development of dependent peoples and their democratic institutions. The document stated loftily that there would be "due respect for the culture of the peoples concerned, their political, economic, social, and educational advancement, their just

\footnotetext{
${ }^{654}$ Russell and Muther, A History of the United Nations Charter, p. 816.

${ }^{655}$ Lord Hailey, The Future of Colonial Peoples, p. 15.

${ }^{656}$ For a fuller explanation, see: Kenneth Robinson, The Dilemmas of Trusteeship: Aspects of British Colonial Policy between the Wars, Chapter 1: The Imperial Context of Trusteeship (London: Oxford University Press, 1965), pp. 1-28.

${ }^{657}$ Russell and Muther, A History of the United Nations Charter, p. 814. Italics included by authors.
} 
treatment, and their protections against abuses." 658 Yet, as MacCallum would feel keenly, there was no explicit mention of how dependencies were going to be protected against abuses, or how protections would be enforced. In addition, there was a failure to explain how the international body planned to "develop self-government," assess "the political aspirations of the peoples," or "assist them in the progressive development of their free political institutions." ${ }^{659}$ MacCallum could see that the United Nations had no intention of intervening in colonial or Trusteeship affairs. This was certainly the view held by British officials. ${ }^{600}$ The Soviets were also not prepared to authorize the United Nations to have any sort of enforcement mechanism over which it did not have a veto. ${ }^{661}$ MacCallum understood that the Great Powers had promised little except to further their own self-interest. How frustrating it must have been for MacCallum to watch post-First World War developments repeat themselves.

The second part of the working paper, which allowed the major powers to militarize strategic trust territories, was equally problematic to those who thought like MacCallum. These proposals threatened to reverse the thrust of the League's Covenant, which had ensured "the prevention of the establishment of fortifications or military and naval bases and of military training of the natives for other than police purposes and the

\footnotetext{
${ }^{658}$ Ibid, Article 73(b), p. 195.

${ }^{659}$ Ibid.

${ }^{660}$ Duncan Hall, Mandates, Dependencies, and Trusteeship (London: Stevens \& Sons Ltd., 1948), p. 285. Hall asserted that the "British commentary on the Charter noted that 'the general declaration . . . does not empower the United Nations Organization to intervene in the application of these principles by the powers concerned."”

${ }^{661}$ Dallin, The Soviet Union and the United Nations, p. 23.
} 
defence of territory." ${ }^{662}$ However, in the new space-time relation created by new weapons of war, these trust territories were judged by the Great Powers to be vital bastions of national and international security. By giving the exclusive authority for strategic trusts to the Security Council, the Great Powers ensured that the General Assembly could not meddle in the affairs of these security outposts. In delegating authority to the Security Council, the Great Powers had circumvented the main grievance mechanism for Trusteeship — investigation in the trust territories and the acceptance of petitions from local inhabitants. In other words, Part B removed from the purview of the Trusteeship Council many of the "trusts" for which the system was primarily designed. Equally alarming, for those with MacCallum's skepticism about imperial powers, was the provision that all strategic trust territories would play their part in the maintenance of international peace and security. The Trusteeship Power could raise armies by conscription, not just to defend their territory, but to fulfill obligations mandated by the Security Council.

In defining the composition of the Trusteeship Council, the Working Paper proposed that trust countries would have a seat on the Council. The Council's responsibilities included: the considering of reports submitted by the administering authority; the examining of petitions in consultation with the administering authority; and the taking of actions, if necessary, in conformity with the terms of the Trusteeship

662 United Nations Information Organization, Documents of the United Nations Conference on International Organization, Vol. 10, pp. 678-680. This proposed provision allowed a trust power to make use of "volunteer forces, facilities, and assistance from the trust territory in carrying out the obligations towards the Security Council ...." 
agreements. ${ }^{663}$ These stipulations, however, failed to address the inherent conflict of interest: how could a member of the Trusteeship Council investigate itself, and would it wish to?

MacCallum's earlier study of the Permanent Mandates Commission (PMC) set out to examine how the imperial powers, through their membership in the League of Nations Council and the PMC, used their position effectively to block efforts by the PMC to investigate grievances made against a mandatory power. ${ }^{664}$ MacCallum pointed out that, following the French bombardment of the Syrian capital in 1925, when 5000 Syrian Arabs had been killed or wounded, the PMC attempted to interview French representatives regarding the assault. France promptly interceded, by using its seats on the League Council and the PMC, to stop the Commission's inquiry. In place of the PMC's independent investigation, France launched its own probe using their own investigators. As MacCallum noted, the French had used their influence on both the League Council and the Mandates Commission to muzzle any impartial examination of France's wrongdoings in Syria. In the end, the French investigation failed to uncover any wrongdoing, nor did it deter French conduct or the policy of crushing Arab opposition to France's mandatory rule. The crackdown against Arab opposition went on unabated. ${ }^{665}$ The Great Powers would surely exercise a similar influence if they became members of

\footnotetext{
${ }^{663}$ Ibid, Article 86 (1 a), and Article 87, 199.

${ }^{664}$ MacCallum, "Functions of the Permanent Mandates Commission," p. 51. As MacCallum noted, the Council rejected PMC initiatives for more reporting "in light of the criticisms of the mandatory governments." The PMC was established under Article 22 (h) of the Covenant as an "advisory" commission. For a more detailed examination of the PMC, see: "Part 1: Mandates and Dependencies: A General View," in H. Duncan Hall's Mandates, Dependencies and Trusteeship.

${ }^{665}$ Phillip S. Khoury, "Factionalism Among Syrian Nationalists During the French Mandate," International Journal of Middle East Studies, Vol. 13, No. 4 (November, 1981), p. 452.
} 
the Trusteeship Council. Without the ability to conduct independent reviews of the trust states, to summon witnesses, to question trust administrators, or to impose sanctions, the Trusteeship Council would be powerless to intervene, leaving trust powers to administer their territories as they saw fit, just as MacCallum had seen under Article 22. ${ }^{666}$

The Canadian delegation, as the government's official report stated, “opposed the principle that the permanent members of the Security Council, whether or not they were trust powers, should be permanent members of the Trusteeship Council." ${ }^{667}$ Canada's attempt to amend the membership criteria, however, was soundly defeated. ${ }^{668}$ According to its Report on the United Nations Conference, and the minutes of the delegation's meetings, Canada did not propose or discuss any other amendments to the proposed provisions on the Trusteeship Council. In the end, the Working Paper's recommendations on the Trusteeship Council constituted a compromise that fused American ideas with the British and French determination to protect administering powers from undue interference by the Council. ${ }^{669}$ Canada had had no impact on the Trusteeship deliberations. Even if MacCallum had been able to make her voice heard in Canadian policy-making, her influence would have carried no further than that. There was, however, a small consolation prize, or perhaps she thought it no consolation at all.

\footnotetext{
${ }^{666}$ Elizabeth MacCallum, “The Class A Mandates,” [n.d.], p. 3, MacCallum Papers.

${ }^{667}$ Canada, Report on the United Nations Conference on International Organization, p. 53. Also see: R. G. Riddell, "Minutes of Meeting for Canadian Delegation," June 6, 1945, External Affairs Records, LAC, RG 25, Vol. 1021, File: 6-F, p. 2.

668 Ibid.

${ }^{669}$ Evan Luard, A History of the United Nations, Vol. 1: The Years of Western Domination, 1945-1955 (New York: The MacMillan Press, 1982), p. 60.
} 
MacCallum was likely the drafter of the section on Trusteeship in the DEA's official Conference report.

\section{Trusteeship Confirmed, Palestine Unresolved}

As previously noted, MacCallum believed that the Palestine dispute posed a threat to the success of the Conference's efforts to construct a Trusteeship system, and foster Great Power co-operation. She knew that the deliberations were bound to influence the future development of Palestine by virtue of the guidelines and mechanisms that the Committee would establish. With increased clashes in Palestine among Arabs and Jews, and the promulgation of the Biltmore Program, MacCallum knew that it was only a matter of time before the British government turned Palestine over to the United Nations. And when the British did so, the importance of the decisions taken at the San Francisco Conference would become critically important. As Eliahu Elath recalled in 1976, the principles that the United Nations adopted for Trusteeship could "undermine the suigeneris provisions of the Palestine Mandate." ${ }^{670}$ Any framework adopted governing the Trusteeship System and the Trusteeship Council would have a profound effect on the outcome of the Palestine dispute.

Following an April 30th mass pro-Zionist demonstration in San Francisco, ${ }^{671}$ Arabs and Jews alike demanded that the issue of the Palestine Mandate be raised at the

${ }^{670}$ Eliahu Elath, Zionism at the United Nation: A Diary of the First Days (Philadelphia: The Jewish Publication Society of America, 1976), p. 6.

671 “60,000 at Rally Back Zionist Plea,” New York Times, April 30, 1945, pp. 22. With more than 60,000 supporters of the Zionist cause in attendance, prominent Americans like Senator Robert Wagner and Mayor La Guardia of New York demanded that the British Government honour its commitment to "facilitate Jewish immigration into Palestine and to help set up a national home for the Jews." Addressing the purpose of the San Francisco gathering, Zionist spokesperson Dr. Stephen Wise 
Conference. Even though the Zionists were denied official status at the Conference, it was obvious - as the demonstration showed - that they were prepared to launch a wide-ranging campaign to advance their cause. The various Jewish groups, and their supporters, seized "on every contact or sign of understanding and sympathy in influential circles or by individuals, whether in national delegations, in public bodies, or among the host of journalists covering the proceedings." 672 The Arabs, on the other hand, used their position as official delegations at San Francisco to press the Conference to annul Jewish rights granted under the Balfour Declaration and the British Mandate agreement of $1922 .^{673}$

MacCallum was well versed in the tactics of Middle East interest groups, and she must have sensed that, in the coming days and weeks, Arab and Zionist efforts would focus on the question of territorial and indigenous rights, which had been articulated in paragraph 5 of Part B of the American working paper. The proposed provision, commonly referred to as the Conservatory Clause, declared that:

Except as may be agreed upon in individual Trusteeship arrangements made under paragraph 4 and 6, placing each territory under the Trusteeship system, nothing in this chapter should be construed in and of itself to alter in any manner the rights of any state or any peoples in any territory, or the terms of any Mandate. ${ }^{674}$

While the provision did not mention Palestine specifically, it was apparent that the intent of the clause was to preserve the existing Mandate until a Trusteeship agreement replaced

\footnotetext{
declared that: "“the first and immediate appeal of this mass demonstration . . . is that the Jewish case be placed upon the agenda of San Francisco."”

${ }^{672}$ Elath, Zionism at the United Nations: A Diary of the First Days, pp. 7-8.

673 The Arab delegations were Egypt, Syria, Iraq, Saudi Arabia, and Lebanon.

${ }^{674}$ Russell and Muther, A History of the United Nations Charter, pp. 827-828.
} 
it. ${ }^{675}$ At their June 1 st meeting, the Canadian delegates were informed of a Commonwealth meeting in which paragraph five was discussed, and of the divisions, it raised among the Great Powers, the Arabs, and the Zionists. ${ }^{676}$ The U. S. wording appeared to confirm the Arabs' worst fear — the American proposal was a thinly veiled attempt to maintain Jewish rights at the expense of Arab democratic rights. It proposed to extend the British promise found in Article 4 of the Mandate, which accorded Zionists and the Jewish Agency "special rights" in Palestine ${ }^{677}$ Egypt challenged the proposition, arguing for a change in wording to "Nothing in this chapter should be construed in and of itself to alter in any manner the rights of the people of any territory or the terms of any mandate." ${ }^{678}$ At the very least, the Arab States "wanted to 'freeze' the status of Palestine, so it could not be placed under Trusteeship on terms they might consider less advantageous to the Palestine Arabs."

The problem of special rights was further complicated by the question of Jewish immigration. If special rights were granted to the Jewish Agency, would they have the authority to alter the immigration quotas set by the 1939 White Paper? Once again, the Egyptians protested, claiming that paragraph five made clear "that only the rights of the inhabitants of a territory were to be protected." ${ }^{\prime 80}$ MacCallum had stated, in "The

\footnotetext{
${ }^{675}$ Urquhart, Ralph Bunche: An American Life, p. 120.

${ }^{676}$ R.G. Riddell, "Minutes of Meeting of Canadian Delegation," June 1, 1945, External Affairs Records, LAC, RG 25, Vol. 1021, File: 6-F, p.2.

677 "British Mandate for Palestine," San Remo Conference, April 24, 1920.

${ }^{678}$ Russell and Muther, A History of the United Nations Charter, p. 828. Egypt's statement was based on the view that Britain's 1939 White Paper was an amendment to the Palestine Mandate of 1922.

${ }^{679}$ Ibid.

${ }^{680}$ Ibid, p. 828.
} 
Palestine Conflict," that the Arabs believed that any "special rights" given to the Jewish Agency, or for that matter, the Zionists, were illegal. ${ }^{681}$ In explaining the Arab perspective, MacCallum pointed out that the Arabs thought that the Jewish Agency constituted an imperium in imperio - a government independent of the authorized government - and should be abolished. MacCallum concurred with this interpretation, believing that neither Zionists nor the Jewish Agency had a legal basis for claiming they had "special rights" in Palestine. ${ }^{62}$ If special rights for minority groups were written into a Trusteeship system, the case for Jewish statehood would be virtually guaranteed. More importantly, the Arabs disputed the assumption that the Big Three powers possessed the moral justification or the legal authority to deny Arab Palestinians their lawful rights.

The issue of "special rights" was a particular concern to the colonial powers. Britain and France were worried that special rights would open up a multitude of demands by various minority groups in their Middle East and North African holdings. ${ }^{683}$ For the Americans, the issue was equally hazardous. The freezing of existing rights would make it impossible, in the interim, to enlarge the rights of "peoples" throughout all of the mandated territories, not just Palestine. This would breed a restiveness the Soviets would surely exploit. The Great Power calculus rested on a precipice: "One mis-step

\footnotetext{
${ }^{681}$ Elizabeth MacCallum, "The Palestine Conflict," October 16, 1929, FPAIS, Vol. 5, No. 16, p. 283.

682 Ibid.

${ }^{683}$ Russell and Muther, A History of the United Nations Charter, p. 828.
} 
would have the Jews as well as the Arabs in an uproar at one or the other being given an advantage. ${ }^{\prime 684}$

Given these developments, MacCallum must have concluded that the weeks of deliberations on Trusteeship had been only marginally successfully. The framework for Trusteeship transferred without a change from the Working Paper of the Consultative Group, was only fractionally better than Article 22 of the League of Nations Covenant. Moreover, the proposed provisions on Trusteeship were clearly mechanisms intended to maintain the Great Power status quo and perpetuate the colonial system. The Five-Power Consultative Group had protected the strategic, territorial, and commercial interests of the colonial and Great Powers, and provided the Trusteeship Council with little or no authority to inspect, reprimand, or seize a Trusteeship after its provisions had been violated. As far as MacCallum was concerned, Trusteeship systems provided no means of improving the lives of millions of disenfranchised peoples. They lacked a coherent blueprint of how the international organization would mentor dependent territories, or protect their interests. More importantly, the plan for Trusteeship had neither resolved the basic differences between the American and British governments on colonialism, nor altered Soviet suspicions concerning Western intentions. MacCallum surely thought, rightly so, that the Great Powers were prepared to use Trusteeship, and Palestine in particular, as a political weapon against their rivals.

\footnotetext{
${ }^{684}$ Louis, Imperialism at Bay, p. 544.
} 
The continued differences that dogged America's and Britain's approach to Trusteeship and Palestine confirmed MacCallum's belief that the Canadian approach had been a serious miscalculation that would haunt them. The Canadian strategy had done nothing to resolve the Anglo-American differences concerning colonialism and Palestine, or strengthen the safeguards that would protect the interests of dependent peoples around the world. It only succeeded in ensuring that Canada did not commit itself on the Colonial question - something that was distasteful to MacCallum but not to the prime minister. Regarding Palestine, MacCallum saw the Western powers abruptly cast all notions of Arab rights and grievances aside. Canada had failed to bridge the AngloAmerican differences on Palestine; instead, in true Kingsian style, Canada had navigated a steady course away from contested land.

\section{Conclusion}

At the United Nations Conference on International Organization in San Francisco, International Trusteeship was one of the great challenges. Throughout the war years, with only a half-hearted conviction to establish a comprehensive system of international administration, the Great Powers had avoided addressing the question of liberating colonial and mandated territories. The Great Powers now continued to be divided over how best to define, administer, and supervise the management of the old League of Nations' Mandates System, and of colonial and protectorate territories.

The problems of Trusteeship were the problems of power. Trusteeship pitted the interests of the colonial powers against the anti-colonial powers. The Great Powers' strategic and commercial concerns were the fundamental ingredients in their equation. 
They outweighed any consideration of the rights of dependent territories. As the United Nations Conference wrapped up, the Trusteeship bargain that emerged was one that favored the Great Powers. It provided the United States with the exclusive control of strategically vital territories in the Pacific, while ensuring that the colonial powers' empires were kept intact, beyond the reach of the United Nations.

For Elizabeth MacCallum, the San Francisco Conference was a bittersweet episode in her career. On the positive side, she was just one of two women chosen to represent Canada at the Conference. It was a singular distinction for her to be selected for the Canadian delegation, and more importantly, to be assigned to the Committee on Trusteeship. Her selection reflected the high opinion of her ability and judgment held by the department's senior officers, notably under-secretary Robertson and associate undersecretary Wrong. Yet, she was undoubtedly frustrated by the fact that she was given little opportunity to prove her value or demonstrate her expertise. The Great Powers' decision to draft the Trusteeship framework behind closed doors had left little room for lesser powers to play meaningful roles. As long as Great Powers' strategic and commercial interests dictated the form that Trusteeship would take, MacCallum knew there would be little work for the smaller powers. Furthermore, Canada deferred to the interests of the Great Powers on the issue, since, Mackenzie King insisted, it did not administer any mandated territories or possess any colonies.

MacCallum's frustration was intensified by what she surely believed was a miscalculation in the government's approach to Trusteeship. The Canadian government had ignored the abuses of the Great Powers in the Middle East, Africa, and the Far East 
during the interwar period. Why was the prime minister willing to accept, without reservation, Great Power domination of the Trusteeship system? If the goal of the Canadian approach was to facilitate agreement among its major partners, Britain and the United States, how did Canada attempt to facilitate that outcome? By leaving the blueprint for Trusteeship in the hands of the Great Powers, MacCallum knew that Canada had sacrificed a legitimate opportunity to strengthen the safeguards that would have protected the interests of the dependent territories. Even if Canada's challenge had been cast aside by the Great Powers, the debate which would have ensued might have contributed to the development of a fair and just Trusteeship system.

The consequences of this failed approach were especially evident with respect to Palestine. MacCallum recognized that the provisions covering "special rights" would do little to resolve the outstanding questions regarding Palestine's future status. The British and American impasse over Jewish rights meant that the issue was once again deferred until a clearer picture of Great Power objectives and interests was defined. MacCallum knew this would intensify Arab suspicions of the Western powers, and embolden Arab and Zionist extremists to take matters into their hands.

The Great Powers had failed to entrust the Trusteeship Council — the United Nations' purported watchdog — with the authority to inspect, reprimand, or seize a Trusteeship after a violation of Council rules had been committed. Moreover, as MacCallum feared, the Council possessed no meaningful machinery for improving the lives of millions of disenfranchised peoples. It lacked the means to mentor the dependent 
territories, establish self-governing institutions, or balance the interests of the indigenous population and the strategic and commercial interests of the Great Powers.

MacCallum, like her country, remained on the sidelines during the San Francisco deliberations. Yet she had met many of the influential players involved in shaping Colonial and Trusteeship policy, particularly many of the leading Arab intellectuals and policymakers involved in the Palestine question. She was given the opportunity to work more closely with senior department officials, who had an increased awareness of her capabilities and her willingness to be a team player. While MacCallum recognized her limited role, San Francisco had provided her with insights and experiences that would be useful as her analyst's career moved forward. 


\section{Chapter 5 Palestine and MacCallum's Warnings, 1945-46}

With the conclusion of the San Francisco Conference on June 26, 1945, and a welcome respite in view, Elizabeth MacCallum returned to Ottawa, where she resumed her duties as head clerk with the Department of External Affairs' (DEA) Second Political Division. ${ }^{685}$ Soon after her return, international events conspired to overtake the United Nations' effort to establish itself as the principal agent for international peace and conflict management. The Palestine dispute remained MacCallum's chief preoccupation. As she had anticipated, it threatened to imperil Great Power relations, hijack Canada's foreign policy, and quite possibly, trigger a major war in the Middle East. ${ }^{686}$ During the next nineteen months, MacCallum was compelled to draw to the government's attention the dangers associated with its anemic Palestine policy, the growing European refugee crisis, and the mounting Anglo-American tensions over Jewish statehood. In warning Canadian officials of the dangers associated with Palestine, MacCallum challenged the logic of the government's thinking towards the Middle East — it was not, after all, only a British issue. In doing so, she provided the substance and context for a more informed and balanced departmental approach to Palestine.

Before proceeding to an examination of MacCallum's efforts regarding the Palestine issue, and how and why External Affairs found itself involved in a region where

685 J. L. Granatstein, A Man of Influence: Norman A. Robertson and Canadian Statecraft, 1929-68 (Toronto: Deneau, 1981), p. 195. The Second Political Division, which came out of the January 1945 reorganization of the department, was responsible for Commonwealth, European, Middle Eastern, and African Affairs. George Glazebrook was the head of this new division. For more detailed information on the reorganization, see: John Hilliker, Canada's Department of External Affairs: Vol. 1, The Early Years, 1909-46 (Montreal \& Kingston: McGill-Queen's University Press, 1990), p. 276.

${ }^{686}$ Elizabeth MacCallum, "Palestine: Postwar Policy and the 1939 White Paper," [n.d.], King Papers, Library and Archives Canada (LAC), MG 26, J4, Vol. 310, File: 3308, C214545, C214549. 
its government apparently had no vested national interests, it is necessary to consider how three transformative international events altered the fragile landscape of the Middle East and led Canada to engage finally with the issue of the Palestine Mandate.

\section{Transformations}

With the death of Franklin Delano Roosevelt (FDR) on April 12, 1945, and the ascension of Harry S. Truman to the presidency, America's vacillating Palestine policy came to a hasty end. Throughout the war years, Roosevelt had avoided any formal commitment to either the Arabs or the Jews. He regarded the Palestine Mandate as Britain's responsibility. ${ }^{687}$ To interfere would have had dire domestic and international consequences that could conceivably affect the Anglo-American war effort. Therefore, Roosevelt and his State Department officials reasoned that they would do nothing to change the status quo. ${ }^{688}$ Instead, the Roosevelt administration concluded that it was best to leave the question of Palestine for the soon to be created United Nations Organization (UNO). ${ }^{689}$ Until then, the Americans were resolved that the administration's course of action in the region should not exceed the president's 1943 pledges that "no decision altering the basic situation of Palestine should be reached without fully consulting with

${ }^{687}$ Samuel Halperin and Irvin Oder, "The United States in Search of a Policy: Franklin D. Roosevelt and Palestine," The Review of Politics, Vol. 24, No. 3 (July, 1962), p. 322.

${ }^{688}$ Ibid, p. 340.

${ }^{689}$ Lieutenant-Colonel Harold B. Hoskins, "Memorandum to Deputy Director of Office of Near East and African Affairs," March 5, 1945, in Foreign Relations of the United States (FRUS), 1945, The Near East and Africa, Vol. 8 (Washington D. C.: Government Printing Office, 1969), p. 691. Harold Hoskins, the economic adviser to the U. S. Legation in Egypt, noted in his memorandum that the "President said he thought such a plan [Trusteeship for Palestine] might well be given to the United Nations Organization after it had been set up to work out problems along these lines." 
both Jews and Arabs," ${ }^{690}$ and that "he would make no move hostile to the Arab people and would not assist the Jews . . . against the Arabs. ${ }^{" 691}$ Although loosely worded and subject to varying interpretations, these pledges became the de facto policy of the State Department and President Roosevelt until the end of the war.

President Truman, on the other hand, seized the Palestine and Jewish problem as a personal and political mission. As he noted in his memoirs, the "plight of the victims who had survived the mad genocide of Hitler's Germany was a challenge to Western civilization, and as President I undertook to do something about it.."${ }^{992}$ Truman rejected Roosevelt's assessment that Palestine's political future, and the exodus of Europe's Jewry to Palestine, were exclusively British issues, and equally important, that they should be treated separately. Truman viewed them as ethical issues, ${ }^{693}$ holding that obligations to the Jews were a moral imperative. For that reason, Truman believed that the British should be compelled to honour the Balfour Declaration, a promise that "should be kept just as all promises made by responsible civilized governments should be kept. ${ }^{" 694}$ For Truman, the "Balfour Declaration always seemed to go hand in hand with the noble policies of Woodrow Wilson, especially the principle of self-determination." ${ }^{965}$ Truman,

\footnotetext{
${ }^{690}$ Cordell Hull, "Secretary of State to the Minister of Egypt," May 26, 1943, in FRUS, 1943, The Near East and Africa, Vol. 4 (Washington, D. C.: Government Printing Office, 1964), p. 787.

${ }^{691}$ Wallace Murray, "Memorandum by Director of the Office of Near Eastern and African Affairs to Acting Secretary of State," April 6, 1945, in FRUS, 1945, Vol. 8, pp. 701-702.

${ }^{692}$ Harry S. Truman, Memoirs, Vol. 2: Years of Trial and Hope, 1946-1952 (Garden City, N. Y.: Doubleday \& Company, Inc., 1956), p. 132.

${ }^{693}$ J. Philip Rosenberg, "The Belief System of Harry S. Truman and Its Effect on Foreign Policy DecisionMaking during his Administration," Presidential Studies Quarterly, Vol. 12, No. 2 (Spring, 1982), p. 231.

${ }^{694}$ Truman, Years of Trial and Hope, p. 132.

${ }^{695}$ Ibid, p. 133.
} 
therefore, was prepared to use his new political power to oppose the British White Paper of 1939 and facilitate the establishment of a Jewish state in Palestine. In making Palestine and the Jewish people his personal undertaking, Truman effectively side-lined the State Department's Office of Near Eastern and Africa Affairs (ONEAA), his government's chief interpreter of and adviser on Middle East affairs. ${ }^{696}$

However, for many senior State Department officials, such as Loy Henderson, the director of the Office of Near Eastern Affairs, Truman's support for a Jewish homeland was largely motivated by domestic political considerations. ${ }^{697}$ For Truman, the politician, the rewards were obvious. David McCullough, the biographer of Truman, acknowledged that the president's support for a Jewish homeland was of course good politics. In particular, McCullough suggested that:

in such big states as Pennsylvania or Illinois, and especially in New York where there were 2.5 million Jews. More important even than Jewish votes to the destitute Democratic Party could be Jewish campaign contributions. Nor was there any doubt that the Republicans stood ready to do all they could for the Jewish cause and for the same reasons. But beyond the socalled "Jewish vote" there was the country at large, where popular support for a Jewish homeland was overwhelming. ${ }^{698}$

696 Evan M. Wilson, “The Palestine Papers, 1945-1947," Journal of Palestine Studies, Vol. 2, No. 4 (Summer, 1973), p. 45. Also see: Gordon Merriam, "Memorandum to Director of the Office of Near Eastern and African Affairs," September 26, 1945, in FRUS, 1945, Vol. 8, footnote 42, pp. 745-746. In a hand-written note to Loy Henderson, George Allen, the deputy director of the Office of Near Eastern and African Affairs, asserted that: "It seems apparent to me that the President (and perhaps Mr. Byrnes as well) have decided to have a go at Palestine negotiations without bringing NEA [ONEAA] into the picture for the time being."

${ }^{697}$ Bruce J. Evensen, "The Limits of Presidential Leadership: Truman at War with Zionists, the Press, Public Opinion and His Own State Department over Palestine," Presidential Studies Quarterly, Vol. 23, No. 2, President Perception and Persuasion (Spring, 1993), p. 270.

${ }^{698}$ David McCullough, Truman (New York: Simon \& Schuster, 1992), p. 596. 
Scholar Bruce Evensen, suggested that President Truman's new position was at variance with Senator Truman's stance on Palestine. During his ten years in the Senate, stated Evensen, Truman's voting record on a Jewish State in Palestine was unspectacular and smacked of political opportunism.

In May of 1942, Truman officially endorsed the creation of a Jewish Army in Palestine, but abruptly withdrew his endorsement when a Jewish group used his stand to criticize American policy in Palestine. On the 25th anniversary of the Balfour Declaration, which pledged the British government to the building of a Jewish "homeland" in Palestine, Truman joined 68 other senators and 194 representatives in hailing the event. But when he had the opportunity in the fall of 1944 to support unlimited Jewish immigration to Palestine, he followed the will of the Roosevelt administration and refused. ${ }^{699}$

At the same time that American policy on Palestine was being remodelled, the British political landscape was undergoing a profound redesign of its own. To the surprise of Whitehall and Britain's wartime allies, Churchill's government was defeated in the general election of 1945 by the British Labour Party. The political repercussions of Labour's victory were apparent in Washington's and London's Palestine policies. For the Arabs, Labour's victory represented the "dawn of a new political era," which would bring with it a "radical change in British Imperial policies." 700 The Zionists, however, believed that Labour's win was a positive step forward for Jewish statehood. While Churchill had championed the Jewish cause, Zionists believed that the Labour party was more likely to support the establishment of a Jewish state. At the 1944 Labour party congress, the rank and file of the party wholly endorsed the national executive's report, which called for the

\footnotetext{
${ }^{699}$ Evensen, “The Limits of Presidential Leadership,” p. 270.

${ }^{700}$ Youssef Chaitani, Dissension Among Allies: Ernest Bevin's Palestine Policy between Whitehall and the White House, 1945-1947 (London: Saqi Books, 2002), p. 13.
} 
repudiation of the 1939 White Paper policy and the establishment of a Jewish state in Palestine. The party's executive advocated a policy of unrestricted Jewish immigration, the timely expulsion of the Arabs to other Arab states, and a re-examination of Palestine's borders. ${ }^{701}$ Labour's position was not an election manoeuvre to curry favour with Anglo-Jewry; the party had supported the Zionist project eleven times since the enunciation of the Balfour Declaration in $1917 .^{702}$ Clement Attlee, the party leader and new prime minister, had advocated throughout the war years for an independent Jewish state. $^{703}$

The U. S. State Department was skeptical about the Labour Party's intentions. In a July 30, 1945 memorandum, Loy Henderson informed Joseph Grew, the acting secretary of state, that it was unlikely "that the Labour government will attempt to implement the resolution passed at the 43rd Annual Conference of the Labour Party of December, 1944. It does, however, appear likely that the Labour Government will modify or repeal the White Paper policy of 1939, especially with respect to Jewish immigration."704

Labour's commitment to repealing the 1939 White Paper would not see the political light of day. In early October 1945, Prime Minister Clement Attlee struck down the Party's Palestine policy and closed Jewish immigration to Palestine indefinitely. More

\footnotetext{
${ }^{701}$ Harold Wilson, The Chariot of Israel: Britain, America, and the State of Israel (New York: W. W. Norton \& Company, 1981), p. 123. Also see: Hugh Dalton, The Fateful Years, 1931-1945, Vol. 1 (London: Frederick Muller, Ltd., 1957), pp. 425-426.

702 Wilson, The Chariot of Israel, p. 123.

${ }^{703}$ Ibid, p. 125.

${ }^{704}$ Loy Henderson, "Memorandum to the Acting Secretary of State," July 30, 1945, in FRUS, 1945, Vol. 2, p. 1405.
} 
importantly, he opposed a Zionist state in Palestine, and sought to maintain control over Palestine as a British strategic asset. ${ }^{705}$ It is unclear if this meant that the British government was considering the making of Palestine into a strategic Trusteeship. "This obviously came as a shock to Zionists," stated British historian Peter Clarke. No longer would a British prime minister, implicitly or explicitly, champion the interests of the Jewish people in Palestine, as Churchill had done. ${ }^{706}$ As Labourite Harold Wilson maintained, "There cannot have been in twentieth-century British history a greater contrast between promise and performance than was shown by the incoming Government over Middle Eastern issues." ${ }^{, 707}$ The Jewish people would now have to seek the support of the American president for their future.

The change in Anglo-American leadership created a fundamentally different and confrontational relationship between the United States and Great Britain, particularly in respect to their diametrically opposed approaches to the resolution of the Palestine and European refugee crises. In Britain and the Jews of Europe, 1939-1945, Bernard Wasserstein stated:

Towards the end of the war, differences emerged . . . . In the U.S.A., this led to a modification of policy on the refugee question, in Britain to renewed consideration of the vexed problem of the future of Palestine. On both issues the British and American governments now found themselves drifting dangerously apart. ${ }^{708}$

\footnotetext{
705 Michael Makovsky, Churchill's Promised Land: Zionism and Statecraft (New Haven, Conn.: Yale University Press, 2007), p. 229.

${ }^{706}$ Peter Clarke, The Last Thousand Days of the British Empire: Churchill, Roosevelt, and the Birth of the Pax Americana (New York: Bloomsbury Press, 2008), p. 389.

707 Wilson, The Chariot of Israel, p. 125.

${ }^{708}$ Bernard Wasserstein, Britain and the Jews of Europe, 1939-1945 (Oxford: Clarendon Press, 1979), pp. 321-322.
} 
The last transformational change in the international context occurred as a result of the Allied forces' liberation of Nazi forced labour and concentration camps. What the Allies discovered throughout Germany, Austria, and Poland was the carnage of Hitler's "final solution."709 While the Allied governments had known about the mass deportations and murders of Jews as early as May $1942,{ }^{710}$ the scope only became apparent after the Allied Powers had seized Nazi-occupied territory. Daily newspapers, newsreels, and magazines overwhelmed American, British, and Canadian readers and viewers with images and stories of the slaughter of six million Jews. ${ }^{711}$ Graphic scenes depicted "corpses stacked like firewood and piled in mass graves, crematoria full of ashes and charred bones, emaciated survivors wearing striped uniforms, electrified barbed wire fences, empty canisters of cyanide pellets, gas chambers disguised as shower rooms. . . .${ }^{9712}$ For those Jews who had survived, ${ }^{713}$ Europe only promised more misery. "Their homes, synagogues, and community centres had been destroyed or seized . . ." though postwar European states, such as Rumania, Hungary, and Poland, had pledged to safeguard their Jewish populations, anti-Semitism quickly returned. In Kielce, Poland, on

709 Irving Abella and Harold Troper, None is Too Many: Canada and the Jews of Europe, 1933-1948 (Toronto: Lester \& Orpen Dennys Ltd., 1982), p. 192.

${ }^{710}$ Ibid, p. 148.

711 Tony Judt, Postwar: A History of Europe since 1945 (New York: Penguin Books, 2005), p. 804.

712 Lawrence Baron, "The First Wave of American 'Holocaust' Films, 1945-1959," The American Historical Review, Vol. 115, No. 1 (February, 2010), p. 95.

713 Gerard Daniel Cohen, In War's Wake: Europe's Displaced Persons in the Postwar Order (New York: Oxford University Press, 2012), p. 126.

714 David Bercuson, Canada and the Birth of Israel: A Study in Canadian Foreign Policy (Toronto: University of Toronto Press, 1985), p. 34. 
July 4, 1946, the medieval charge of blood libel ${ }^{715}$ was revived, and in the pogrom that followed, forty-two Jews who had survived the camps were brutally murdered while the authorities stood passively by. ${ }^{716}$ The fate of the remaining Jewish Displaced Persons (DPs) and the rise of postwar anti-Semitism in Europe became a trip wire for the heated debates that would surface among American, British, and Zionist leaders in late 1945 and early 1946.

\section{Canada's Growing Unease and MacCallum's Concerns}

Since her return from San Francisco, MacCallum had closely followed the developments concerning Palestine — assessing British political intelligence reports and monitoring ongoing diplomatic correspondence, press coverage, and American and British declaratory statements — and the efforts of pro-Zionist forces in Canada. By the late summer and early fall of 1945, many of the department's concerns about deteriorating Anglo-American relations had been realized. ${ }^{717}$ The Great Power alliance appeared to be crumbling under the weight of evolving strategic interests. ${ }^{718}$ More disconcerting to King and External Affairs was that the Anglo-American wartime relationship had become an association that was remote, stiff, and at times adversarial.

\footnotetext{
${ }^{715}$ Alan Dundes (ed.), The Blood Libel Legend: A Casebook in Anti-Semitic Folklore (Madison: University of Wisconsin Press, 1991). The first written accounts of the blood libel appeared in the 12th century, but the roots of the term go back to antiquity. Blood libel refers to the use of Christian children's blood for the purpose of preparing Passover Matzo or unleavened bread. This legend caused the persecutions and killings of Jews. Even in the 21th century, echoes of it were heard among many Moslem Mullahs and clerics.

${ }^{716}$ Michael Cohen, "Churchill and the Jews: The Holocaust," Modern Judaism, Vol. 6, No. 1 (February, 1986), p. 33.

717 James Eayrs, In Defence of Canada: Peacemaking and Deterrence (Toronto: University of Toronto Press, 1972), p. 174.

${ }^{718}$ Ibid.
} 
Unlike the Roosevelt-Churchill relationship, which admittedly became less close as the war progressed, the Truman-Attlee relationship seemed unable to transcend their differences. It seemed that there was no longer a common cause or purpose, just selfinterest. The qualities that had defined and strengthened the wartime Anglo-American alliance never fully blossomed for the two postwar leaders.

In his memoirs, Lester Pearson called to mind the Department of External Affairs' (DEA) mounting concerns about the United States' growing dominance, and equally important, its impact on Canadian foreign policy.

The country whose policies would now concern us most would not be Great Britain but the United States. That country was now a super-power. Washington, not London, would determine, with Moscow, whether peace, progress, and even survival were possible. American policies, therefore, must be watched closely. From their consequences Canada could not escape. . . ${ }^{719}$

This new reality forced Ottawa to consider how best to adapt to the rapidly changing Great Power circumstances. Historian Robert Bothwell observed that "the main adjustment was curiously traditional, responding to a situation that had existed ever since Canada took a distinct form, back in the eighteenth century, with the clash between the revolutionary American republic and the British Empire."720 For the East Block, this meant a policy and course of action that were also traditionally Canadian: the amelioration of Anglo-American differences.

\footnotetext{
${ }^{719}$ Lester B. Pearson, Mike: The Memoirs of the Right Honourable Lester B. Pearson, Vol. 1, 1897-1948, (Toronto: University of Toronto Press, 1972), p. 284.

${ }^{720}$ Robert Bothwell, Alliance and Illusion: Canada and the World, 1945-1984 (Vancouver: UBC Press, 2007) p. 41.
} 
The growing divergence between Canada's two partners was particularly evident in their approaches to Palestine and the Jewish refugee crisis of 1945. Throughout the war years, there had been an implicit understanding among American and British, and to a lesser degree, Canadian officials, that there were domestic and international dangers inherent in supporting Jewish statehood or repudiating the 1939 British White Paper. Given the Arabs' implacable opposition to unrestricted Jewish immigration and a Jewish state in Palestine, ${ }^{721}$ Churchill, Roosevelt, and King recognized that a Jewish state could only be imposed on Palestine and its Arab majority by force of arms, a proposition the Allies were unwilling to support. Consequently, all three leaders avoided any policy that formally or implicitly committed their countries to a position on Palestine's status until after the war. On the question of immigration of Jews to their respective countries, all three leaders resisted substantial reforms of their immigration policies to allow the entrance of the wartime refugees,${ }^{722}$ leaving the question of Europe's Jewry unresolved.

As a result of a series of arbitrary American pronouncements and calculated British responses, beginning at the Potsdam Conference and continuing throughout 1946, there was little doubt within External Affairs that Canada would be unable to avoid being

721 J. W. Pickersgill and D. F. Forster (eds.), The Mackenzie King Record: Vol. 2, 1944-1945 (Toronto: University of Toronto Press, 1968), p. 325. On March 9, 1945, at a White House meeting with Mackenzie King, Roosevelt briefed the Canadian prime minister on his meeting with King Ibn Saud of Arabia and Haile Selassie of Ethiopia. Undoubtedly, FDR told the prime minister that Ibn Saud and Selassie had made it clear that the Arab and Moslem Worlds would never tolerate the establishment of a Jewish State in Palestine.

${ }^{722}$ For the various national perspectives, see: Irving Abella and Harold Troper, None is Too Many: Canada and the Jews of Europe, 1933-1948 (Toronto: Lester \& Orpen Dennys Ltd., 1982), p. 149; Robert Dallek, Franklin D. Roosevelt and American Foreign Policy, 1932-1945 (New York: Oxford University Press, 1979), p. 446; Bernard Wasserstein, Britain and the Jews of Europe, 1939-1945 (Oxford: Clarendon Press, 1979), p. 337; Peter Clarke, The Last Thousand Days of the British Empire (New York: Bloomsbury Press, 2008), p. 230; Ben Shephard, The Long Road Home: The Aftermath of the Second World War (New York: Anchor Books, 2012), pp. 331-334. 
drawn into an Anglo-American clash over Palestine. And yet, there was no indication that Mackenzie King had altered his view that Palestine was a British issue and no concern of Canada. King's position would have been reinforced by the fact that there was no longer a consensus among the three countries regarding the Jewish question. On August 31, Viscount Christopher Addison, ${ }^{723}$ who had replaced Viscount Cranborne as the British minister in charge of the Commonwealth, alerted DEA officials to the consequences if the United States maintained its present course concerning Palestine. Addison reported that, on July 24, 1945, Churchill was handed a memorandum at the Potsdam Conference from President Truman urging the British government to disregard their commitment to the 1939 policy and their previous commitments to the Arabs. Truman insisted that:

There is great interest in America in the Palestine problem. The drastic restrictions imposed on Jewish immigration by the British White Paper of May, 1939, continue to provoke passionate protest from Americans most interested in Palestine and in the Jewish problem. They fervently urge the lifting of these restrictions which deny to Jews, who have been so cruelly uprooted by ruthless Nazi persecutions, entrance into the land which represents for so many of them their only hope of survival. Knowing your deep and sympathetic interest in Jewish settlement in Palestine, I venture to express to you the hope that the British government may find it possible without delay to take steps to lift the restrictions of the White Paper on Jewish immigration into Palestine. ${ }^{724}$

Truman's memorandum made it clear to the Foreign Office, and undoubtedly to External Affairs officials as well, that the new president's request was based upon a narrowly political calculus — placating American Zionists.

723 Viscount Addison was secretary of state for dominion affairs in Attlee's first cabinet, directing the transformation of the Dominions Office into the Commonwealth Relations Office.

${ }^{724}$ Viscount Addison, "Secretary of State for Dominion Affairs to Secretary of State for External Affairs," Circular D. 107, August 31, 1945, External Affairs Records, LAC, RG 25, Vol. 5745, File: 47-B (1), Part 1, p. 1. 
Equally concerning to British officials was Truman's implicit suggestion that this action should be taken without consulting the Arabs. According to Evan Wilson, Canada's chief contact on the Palestine Desk at the State Department, a Zionist delegation led by David Ben-Gurion, a prominent Zionist leader in Palestine, had conveyed to him the view that the Jewish people would not "recognize that an Egyptian pasha or a Bedouin sheikh, or an Iraqi bey had any rights or interest in the Palestine question." 725 In other words, Jewish leaders saw the claims of any Arab outside of Palestine as preposterous, which may partially explain Truman's effort to remove nonPalestinian Arabs from any discussion of the matter.

To MacCallum, Truman's proposal constituted a major threat to the Arab World and peace in the region. She had already concluded in 1944 that a mass migration of Jewish refugees into Palestine would constitute a threat in the minds of the Arabs. Denying the Arab people a voice in Palestine's future would surely be looked upon as a further act of Western betrayal and aggression, for Palestine was not the property of Western Powers to give away. To impose an immigration program of this scale on Palestine, MacCallum stated, would violate the core principle of the Atlantic Charter, Woodrow Wilson's principle of self-determination, and Roosevelt's pledges to do no harm to the Arab people. ${ }^{726}$

\footnotetext{
${ }^{725}$ Evan Wilson, “Memorandum of Conversation,” June 27, 1945, in FRUS, Vol. 8, p. 714.

726 Elizabeth MacCallum, "Palestine: Postwar Policy and the 1939 White Paper," [n.d.], William Lyon Mackenzie King Papers (King Papers), LAC, MG 26, J4, Vol. 310, File: 3308, C214548.
} 
Churchill, undoubtedly relieved that he did not have to deal with the president's request, side-stepped the issue and turned Truman's memorandum over to Attlee and his incoming Labour government. However, before Attlee could respond, Truman told members of the American press, "we want to let as many Jews into Palestine as is possible. . .."727 The president had made his position clear. America was no longer willing to respect Britain's Palestine policy or take a backseat in Palestinian affairs. Moreover, Truman was sending a clear message to the British that the United States was determined to take a leading role in the Palestinian question. ${ }^{728}$ Whether intended or not, Truman's statement was a rebuff of Britain's Middle East policy, and it challenged Canada's policy of non-interference in Britain's colonial policies.

In a second cautionary message, Addison informed the secretary of state for external affairs that Truman had sent a personal message to Attlee on August 31 urging him to approve certificates for the immediate entry into Palestine of 100,000 Jews then in refugee camps in Germany and Austria. ${ }^{729}$ Addison added that Truman's new demand not only incensed Attlee, given the fact that he had told the president on July 31 st that he

727 James Byrnes, "Secretary of State to the Consul General at Jerusalem," August 18, 1945, in FRUS, 1945, Potsdam Conference, Vol 2, p. 1407.

728 "Memorandum by Mr. William Yale of the Division of Near Eastern Affairs," July 25, 1945, in FRUS, 1945, Vol. 8, p. 718. In assessing the Palestine mandate, Yale stated that: "the British Government cannot continue to administer Palestine under a mandate of the League of Nations, which will cease to exist after the United Nations comes into existence on the ratification of the Charter. It is therefore inevitable that the status of Palestine will be changed." Yale noted that the British Government could not change the existing rights of the United States in Palestine without the assent of the United States.

${ }^{729}$ Viscount Addison, "Secretary of State for Dominion Affairs to Secretary of State for External Affairs," Circular D. 1816, September 26, 1945, External Affairs Records, LAC, RG 25, Vol. 5745, File: 47B(1), Part 1, p. 1. Also see: "President Truman to Prime Minister Attlee," August 31, 1945, in FRUS, 1945, Vol. 1, The Near East and Africa (Washington: United States Government Printing Office, 1969), pp. 737-739. 
could not respond to the request until his government had time to consider the matter, ${ }^{730}$ but it had also infuriated Arab and Moslem leaders in the Middle East and India, who demanded to know what business the American president had in their affairs. ${ }^{731}$ The Arabs publicly chided the Americans for trying to impose a solution of the Jewish problem on the Arab and Moslem Worlds. ${ }^{732}$ Arab leaders believed, as did MacCallum, that Jewish colonial settlement in Palestine was merely another variant of Western imperialism. As Richard Crossman, who later represented Britain in the Anglo-American Committee of Inquiry, stated: "How can the Arab nationalists, who are determined to end the British regime and to clear the British troops out of Egypt, possibly consent to a slow conquest of Palestine by settlers, who may be Semitic by origin, but behave exactly like European colonialists." ${ }^{, 733}$ As a show of force and solidarity, Arab leaders called for general strikes throughout the Arab and Moslem worlds against American targets.

Even officials in the U. S. ONEAA and the War Department were deeply concerned by the president's statement. The State Department imagined that Truman's statement could transform the Middle East into a violent bloc of anti-American Arab

\footnotetext{
${ }^{730}$ Clement Attlee, "British Prime Minister Attlee to President Truman," July 31, 1945, in FRUS, 1945, Vol. 8, p. 719. Attlee's note to Truman acknowledged the July 24th request but stated that they would respond after studying the matter.

731 "Mr. Jinnah and Palestine: Indignation at American Proposal," The Times (London), October 4, 1945, p. 3. In a telegram to Attlee, Mr. Jinnah, the president of the All-India Muslim League, called Truman's proposal an "unwarranted encroachment on another country, monstrous and highly unjust." Also, see: "Iraq Protest to U. S.," The Times (London), October 4, 1945, p. 3.

${ }^{732}$ Wm. Roger Louis, The British Empire in the Middle East, 1945-1951 (Oxford: Oxford University Press, 1984), p. 410.

${ }^{733}$ Richard Crossman, Palestine: A Personal Record (New York: Harper \& Brothers Publishers, 1947), p. 111.
} 
states, and ultimately hamper America's long-term Middle East policy. ${ }^{734}$ The War Department was also deeply concerned by Truman's proposal. A.D. Reid, assistant to the secretary of war, suggested that, if 100,000 Jewish refugees entered Palestine without Arab consent, it would take a military force of 400,000 to maintain law and order. This, he affirmed, would require the introduction of approximately 200,000 or 300,000 American troops to augment the 100,000 British troops already present in Palestine. It would mean an "indefinite delay in demobilization of U. S. Army forces."735

Viscount Addison further explained to the Canadians that, as Attlee's reply to Truman suggested, ${ }^{736}$ the British prime minister was angered by Truman's less-thansubtle efforts to force Attlee to turn his back on the obligations the British government had made to the Arabs. ${ }^{737} \mathrm{He}$ saw the president's approach as self-serving, largely stemming from his "domestic political calculation, sentimentality and impulse."738 James Byrnes, the American secretary of state, later confirmed Attlee's assessment of Truman's motives. ${ }^{739}$ Addison relayed Attlee's response to Truman, warning the president that a public declaration, before any considered long-term policy was adopted, would do "harm

\footnotetext{
${ }^{734}$ Louis, The British Empire in the Middle East, p. 423.

735 A. D. Reid, "Memorandum by the War Department to the Department of State," September 19, 1945, in FRUS, 1945, Vol. 8, p. 742.

${ }^{736}$ Clement Attlee, "British Prime Minister Attlee to President Truman," September 14, 1945, in FRUS, Vol. 8, p. 739. Attlee's note was an open criticism of the Zionists, who, he stated: "are not now using the number of certificates which are being made available to them ... It appears that they are insisting upon the complete repudiation of the White Paper and the granting of 100,000 certificates, regardless of the effect on the situation in the Middle East which this would have."

737 "Chargé in Iraq to the Secretary of State," September 26, 1945, in FRUS, 1945, Vol. 8, p. 744. The Chargé wrote that local newspapers in Baghdad accused Truman of trying to coerce the British government into dishonouring its obligations to the Arabs of Palestine.

738 Trevor Burridge, Clement Attlee: A Political Biography (London: Jonathan Cape Ltd., 1985), p. 248.

739 Alan Bullock, Ernest Bevin: Foreign Secretary, 1945-1951 (New York: W. W. Norton \& Company, 1983) p. 175.
} 
to relations between our two countries." 740 Following Attlee's warning, Truman appeared to step back from the edge. He promised Attlee that he would postpone addressing the issue until after the London Conference in the fall of 1945. The assurance, however, was short-lived. On September 29, 1945, Truman met with members of the American press and presented his request for the immediate admission of 100,000 Jews into Palestine. In his statement, he claimed that he did so because Britain had yet to respond to his request.

The British press immediately pounced on Truman's statement. ${ }^{741}$ British officials, outraged and embarrassed by the president's ill-timed statement, questioned whether the Americans had a coherent strategy for Palestine. "[T] 100,000 seemed to be the only consistent aim of American policy," stated Ernest Bevin. ${ }^{742}$ While the British foreign minister admitted that large-scale immigration would go a long way in addressing the situation in the refugee camps, he advised that it would not by itself "provide sufficient opportunity for grappling with the whole problem." ${ }^{743}$ Therefore, he questioned Truman's broader strategic plan for the region. Did Truman in fact have a plan or was it just a political gambit to win Jewish votes? Whatever the answer was, MacCallum must have been convinced that it was a big risk to take.

\footnotetext{
${ }^{740}$ Clement Attlee, "The British Prime Minister to President Truman," September 14, 1945, in FRUS, 1945, Vol. 8, p. 739.

741 "Immigration to Palestine," The Times (London), October 2, 1945, p. 3. The newspaper's Parliamentary correspondent condemned the president's statement by asserting that: "Mr. Attlee replied a fortnight ago to President Truman's letter to him on the subject of Jewish immigration into Palestine."

${ }^{742}$ Louis, The British Empire in the Middle East, p. 386.

743 "Text of Statements by Bevin and Truman on Jews and Palestine," New York Times, November 14, 1945, p. 12.
} 
For External Affairs officials and the Canadian prime minister, Addison's dispatches demonstrated the growing disparities between the Americans and the British regarding Palestine. MacCallum had warned in her 1944 paper that the question of Jewish immigration was crucial to postwar stability and Great Power relations. ${ }^{744}$ What would happen when the 50,000 Jewish immigrants and 25,000 refugees, allowed under the terms of the 1939 White Paper policy, entered Palestine? More importantly, what would happen after the allotted number of immigrants and refugees had been apportioned? That time was quickly approaching. Lowell Pinkerton, the American consul-general in Jerusalem, reported to the U. S. secretary of state that, according to the immigration quotas stipulated in the 1939 White Paper, the number of remaining immigration certificates, as of August 1 1945, was 7,881. It was expected, reported Pinkerton, that, with admissions limited to 1,500 a month, without carry-over from previous unfilled monthly quotas, the "total balance will therefore last through December [1945] unless policy is changed." 745

MacCallum knew that it was highly unlikely that the Arabs would consent to further Jewish immigration, and certainly not in the numbers that the Truman had proposed. Nor was it likely that an agreement between the United States and Britain could be easily found. Addison's memoranda had made it clear that American and British authorities were fundamentally divided on this question. The British believed the solution to the Jewish problem lay in finding them homes outside of Palestine, a position strongly

\footnotetext{
${ }^{744}$ MacCallum, "Palestine: Postwar Policy," C214536.

${ }^{745}$ Lowell Pinkerton, "Consul General at Jerusalem to the Secretary of State," August 9, 1945, in FRUS, 1945, Vol. 8, p. 720.
} 
endorsed by the Arab World. ${ }^{746}$ The Americans, on the other hand, called for virtually unlimited immigration into Palestine, which would have resulted in hundreds of thousands of Jewish refugees flooding into the tiny territory. If the American position prevailed, Palestine would become a de facto Jewish state overnight, with or without Arab consent. For MacCallum, this was a recipe for war.

MacCallum recognized that the dilemma posed a serious problem for External Affairs officials and the prime minister. If External Affairs accepted the British position, it would force Canada to open its doors to a torrent of Jewish refugees and displaced persons. ${ }^{747}$ On the other hand, if the Canadian government sanctioned the American proposal, millions of Jewish refugees and displaced persons would pour into Palestine, thereby destabilizing the region and leading to war. ${ }^{748}$ However, if the status quo was maintained, further illegal immigration attempts would be made and increased violent conflict would ensue. In these last two outcomes, it was likely that Canada would be asked by the Security Council to provide troops to keep the peace. This situation would be further complicated by potential Soviet actions. The leading edge of the Great Power clash might well be in the Middle East, and as MacCallum later warned, Truman's actions could be the spark. ${ }^{749}$

\footnotetext{
${ }^{746}$ MacCallum, "Palestine: Postwar Policy," C214548.

${ }^{747}$ Ibid.

${ }^{748}$ Ibid, C214545-C214546.

749 Elizabeth MacCallum, "Background of Discussions on Palestine," August 2, 1946, External Affairs Records, LAC, RG 25, Vol. 5745, File: 47-B (1), Part 1, p. 1.
} 


\section{MacCallum, External Affairs, and the Anglo-American Dispute}

In a reply to Truman's request for the admission of 100,000 Jewish refugees, Bevin counter-proposed the creation of a joint Anglo-American commission to study the questions of displaced persons in Europe and the "absorptive capacity" of Palestine to accept refugees and displaced persons. ${ }^{750}$ The British government had toyed with the idea of turning the Palestine question over to the United Nations; however, the Foreign Office's increased suspicions of Soviet motives in the Middle East led them to propose instead a joint commission of inquiry. ${ }^{751}$ The Foreign Office hoped that the AngloAmerican commission would inform American officials and "get them to act responsibly both on Palestine and the refugee issue."752

Truman initially rejected Bevin's proposal, believing that it was a calculated ploy to delay or defer the issue until a later date. ${ }^{753}$ Then the president, seeking speedy results, seized upon the idea but insisted that the joint commission's final report had to be delivered within 120 days of the commencement of its investigation. ${ }^{754}$ Furthermore, he wanted Palestine to be the sole geographic focus of the study. ${ }^{755}$ Brynes told the British ambassador to the U. S. that, no matter what the findings of the inquiry were, the

\footnotetext{
${ }^{750}$ Ibid.

751 J. C. Hurewitz, The Struggle for Palestine (New York: W. W. Norton \& Company, Inc., 1950), p. 231. Also see: Esco Foundation for Palestine, Palestine: A Study of Jewish, Arab, and British Policies, Vol. 2 (New Haven, Conn.: Yale University Press, 1947), p. 1205. This study suggested there was evidence that during 1946 that the Soviet Union was "displaying interest, not only in the Dardanelles, Iran, and other parts of the Middle East, but also in Palestine."

${ }^{752}$ Louis, The British Empire in the Middle East, p. 392.

${ }^{753}$ Ibid, p. 390.

${ }^{754}$ Ibid.

${ }^{755}$ Ibid.
} 
president was committed to the mass immigration of 100,000 Jews into Palestine. ${ }^{756}$ After getting the 120-day and geographic focus concessions, Truman agreed to the establishment of the commission. However, there was little support for the inquiry among the Arab states and Jewish communities in the United States and Palestine. The Arabs resented the United States' meddlesome role in Palestine. The Zionists, as well, complained about the terms of the inquiry, insisting that Bevin's "interim policy" of limited immigration offered them "a cup of poison with a frigid diplomatic hand.",757

While the British and the Americans wrestled with the purpose and scope of the joint inquiry's mandate, Canadian officials tried to assess what steps they should take in improving Anglo-American relations. John Holmes, writing for the high commissioner for Canada in Great Britain, reported to Ottawa that he had spoken directly with Addison about the growing Anglo-American differences over Palestine. Addison confessed that: "in [British] Government circles and in the press there is considerable exasperation with United States for proposing a step (that is, the immigration of 100,000 Jews), which it is considered would set the Middle East aflame."758 A brief note from Hume Wrong, acting under-secretary of state for external affairs, alerted Lester Pearson, the Canadian ambassador to Washington, to the growing Zionist pressure on the Canadian government,

\footnotetext{
756 James Byrnes, "Secretary of State to British Ambassador to Washington," October 24, 1945, in FRUS, 1945, Vol. 8, p. 786.

${ }^{757}$ Hurewitz, The Struggle for Palestine, p. 238.

758 John Holmes, "High Commissioner for Canada in Great Britain to Secretary of State for External Affairs," No. 2855, October 2, 1945, External Affairs Records, LAC, RG 25, Vol. 5745, File: 47-B (S), p. 1.
} 
citing Holmes' account of his discussion with Addison. ${ }^{759}$ Pearson informed Ottawa that he planned "to make a visit to the Palestine Desk at the State Department to obtain whatever information they might be prepared to give us on the subject."760 In particular, he wanted to get a better picture about the pressures that were pushing Truman's hasty actions. $^{761}$ The department gave Pearson its full approval to proceed with his informal inquiry.

On October 31, 1945, MacCallum wrote her first memorandum in a series of assessments of Anglo-American policies about Palestine and the Jewish refugee crisis. Entitled "Jewish Refugees and the Palestine Problem," 762 her memorandum presented an overview of the possible short-term course of action that the British government could take towards formulating an interim Palestine policy. The basis of her analysis was three British draft statements - Circulars D.1912, D.1971, and D.2005, which had all been sent to Commonwealth governments for comment. ${ }^{763}$ The first part of MacCallum's memorandum compared D.1912, a statement intended for the State Department, with D.1971, a speech prepared for Bevin to be delivered in the House of Commons. She saw D.1912 as a conciliatory note to meet Truman's strongly held belief about the unique misery that the Jewish people had suffered in German-occupied Europe. She believed

\footnotetext{
${ }^{759}$ Hume Wrong, "Acting Secretary of State for External Affairs to Canadian Ambassador to the United States," October 3, 1945, External Affairs Records, LAC, RG 25, Vol. 5745, Part 1.

${ }^{760}$ Lester B. Pearson, "Canadian Ambassador to the United States to the Secretary of State for External Affairs," October 9, 1945, External Affairs Records, LAC, RG 25, Vol. 5745, File: 47-B (1), Part 1, p. 1.

${ }^{761}$ Ibid.

${ }^{762}$ Elizabeth MacCallum, "Jewish Refugees and the Palestine Problem," October 31, 1945, External Affairs Records, LAC, RG 25, Vol. 5745, File: 47-B (1), Part 1, pp. 1-2.

${ }^{763}$ Circular D.1912 (Oct. 12 1945), D.1971 (October 22, 1945), and D.2005 (October 26, 1945) were sent to all Commonwealth governments for comment.
} 
that the note was meant to express Britain's sympathies for the plight of Jewish displaced persons. While MacCallum generally agreed with the document's sentiment, she pointed out that D.1912 had not addressed the full extent of the Nazi persecution. She was concerned that the British draft had not taken into account the non-Jewish peoples, such as the Roma, Communists, and Slavs, who had also suffered terribly at the hands of their Nazis tormentors.

By elevating the plight of Jewish refugees, MacCallum argued that the British were tacitly supporting Truman's goal of focusing the inquiry's efforts entirely on Palestine's capacity to support the influx of a mass Jewish immigration. She was convinced that this would prevent a comprehensive study of all available solutions to the problem. More than that, MacCallum recognized that an investigation that only looked at Palestine would never gain the Arabs' approval. She believed that the "“Arabs regard it as a matter of essential justice that Europe itself should make reparations to the Jews for the sufferings it has inflicted on them." "764 She contended that a "fundamental element in the Arab position is the belief that Asia is not the property of westerners, to be parcelled out among European interests as was done at the close of the last war." By 1945, this view was being strongly voiced by virtually all of the Arab and Moslem leaders in the Middle East. $^{765}$

\footnotetext{
${ }^{764}$ MacCallum, “Palestine: Postwar Policy,” C214548.

765 Ibid. Also see: John Holmes, "High Commissioner for Canada in Great Britain to Secretary of State for External Affairs," October 2, 1945, External Affairs Records, LAC, RG 25, Vol. 1839, Part 3. Holmes reported that he had received a memorandum from Tewfic Saleh Husseini, the acting chairman of Palestine Arab Party, warning the Canadian government that the Arabs would not tolerate any solution that involved Jewish immigration and land transfers in Palestine.
} 
MacCallum also saw a substantial difference between the two British statements. She remarked that D.1971 "had omitted or toned down striking statements that were present" in D.1912. ${ }^{766}$ For example, D.1912 described as "incompatible" the ways of thought and conduct of the two Palestinian communities and their national aspirations, whereas document D.1971 called them merely "difficult to reconcile.",767 More importantly, D.1912 made it clear that British authorities would not tolerate the use of force by either the Zionists or the Arabs. They considered such an action a "breach of faith," which they believed would undoubtedly lead to greater "disturbances throughout the Middle East, involving large military commitments, as well as providing a platform for agitation and unrest in India." D.1971, on the other hand, replaced the term "disturbances" with "reactions" in the Middle East. That document also made no reference to military commitments. D.1971 declared that: "Any attempt to do so [use force] by any party will be resolutely dealt with. The problem must be settled by discussion and conciliation." $" 768$ When read together, contended MacCallum, D.1912 and D.1971 enabled one "to form an impression of how the transition period is to be dealt with." ${ }^{769}$ For the Foreign and Colonial Offices, the Anglo-American inquiry was not meant to recommend or impose a long-term policy. Rather, it was intended to placate the Americans and provide the necessary time for the parties involved in the dispute to find common agreement through peaceful negotiation.

\footnotetext{
${ }^{766}$ MacCallum, "Jewish Refugees and the Palestine Problem," p. 1.

${ }^{767}$ Ibid.

${ }^{768}$ Ibid, p. 2.

${ }^{769}$ Ibid.
} 
In the second part of her memorandum, MacCallum grappled with draft document D.2005, which outlined the proposed terms of reference for the joint Anglo-American Committee of Inquiry on Palestine. The terms revealed to MacCallum that Britain's principal approach to resolving the Jewish refugee problem was not to have Palestine solely bear the brunt of the Jewish refugee crisis. Believing that Palestine was incapable of absorbing the surviving Jewish population of Europe, British officials hoped to repatriate as many Jewish refugees as they could to their countries of origin with the rest provided homes in other countries. This would ensure that the principle of Arab consent was upheld and the White Paper policy respected.

As MacCallum's assessment noted, the British goal would be achieved by looking at the conditions beyond the British- and American-occupied portions of Europe. An investigation of all European countries where Jews had been victimized would enable British authorities to implement practical measures that would enable Jewish refugees to live in Europe free from discrimination and oppression, maintained MacCallum. ${ }^{770}$ As for displaced persons, those who chose not to return to their countries of origin, the investigation would assess the impact that a small group of Jewish displaced persons would have on the "well-being of the peoples now living in that country [Palestine]." The Americans, on the other hand, wanted the joint inquiry to examine the political, economic, and social conditions in Palestine, as they bore upon the problem of Jewish immigration and settlement. For all practical purposes, Truman wanted a study that

\footnotetext{
${ }^{770}$ Ibid.

${ }^{771}$ Ibid.
} 
would estimate the number of Jews wishing to immigrate to Palestine. ${ }^{772}$ The American proposal, therefore, attempted to link Palestine's fate to the Jewish refugee problem. This clearly violated Roosevelt's promise to the Arabs.

MacCallum had two thoughts on the issue. How could the Anglo-American Committee reasonably expect to find a solution in 120 days, given the two communities' intractable differences ${ }^{773}$ Moreover, what recommendation could be crafted that would satisfy all the parties involved? MacCallum's memorandum had set the table for Canadian policy makers. Her analysis mapped out Britain's interim course of action for Palestine and its attitude to unrestricted Jewish immigration. As she correctly pointed out, British officials would continue the course laid out by the White Paper of 1939. As historian Wm. Roger Louis wrote, "the White Paper policy continued to govern Foreign Office thought." 774 MacCallum certainly suspected that Foreign Office officials hoped the joint Committee would prove to the Americans that Palestine was incapable of supporting the mass introduction of Jewish refugees, and consequently, that the Truman administration would be forced to seek other alternative sites for the resettlement of Jewish refugees and displaced persons. MacCallum's study argued that America's sole ambition in the joint inquiry was to seek evidence that Palestine was the only solution to the Jewish refugee crisis. In doing so, America was seeking the means to abrogate the 1939 British White Paper and dramatically alter Britain's present course in Palestine. In other words, the Americans sought to subvert the authority of the Mandatory power.

\footnotetext{
772 MacCallum, “Jewish Refugees and the Palestine Problem,” p. 2.

773 Ibid.

${ }^{774}$ Louis, The British Empire in the Middle East, p. 393.
} 
MacCallum undoubtedly concluded that these aims would create an ever-widening gap in the intentions of the two Great Powers towards Palestine and the plight of the Jewish refugees.

MacCallum's appraisal must have raised serious concerns among senior departmental officials. An investigation that only lasted for 120 days, and one which was so limited in scope, was entirely inadequate to address the deep problems regarding the future status of non-Zionist Jews in Europe. Moreover, the inquiry in MacCallum's judgement would do little to resolve Anglo-American differences over Palestine or the question of Jewish statehood. On the contrary, it appeared that the inquiry would only exacerbate Anglo-American differences, threatening a collision of Great Power interests in the Middle East, which would undoubtedly draw the attention of the Soviets and the rest of the colonial powers. ${ }^{775}$

On November 13, less than two weeks after MacCallum's memorandum was completed, Ernest Bevin delivered a speech in the British House of Commons on the proposed Anglo-American Committee of Inquiry. ${ }^{776}$ Bevin's statement closely echoed the analysis in MacCallum's October 31st memorandum. The Holocaust, said Bevin, was not limited to the Jews; the settlement of the Jewish refugee problem should not be restricted to Palestine alone; and the joint committee's recommendations needed to be acceptable to the Arabs, Moslems, and non-Zionist Jews alike. The foreign secretary also articulated his concern about the influence that political Zionism was having in the United States,

\footnotetext{
${ }^{775}$ Ibid.

${ }^{776}$ Richard P. Stevens, American Zionism and U. S. Foreign Policy, 1942-1947 (New York: Pageant Press, Inc., 1962), p. 141.
} 
Britain, and the Dominions. This was a clear criticism of American Zionists and their aims for the inquiry. At the same time, he declared that "the cause of Palestinian Arabs has been espoused by the whole Arab World and more than 90,000,000 co-religionists in India."777 In Palestine itself, remarked Bevin, "there is always a serious risk of disturbance on the part of one community or the other, and such disturbances are bound to find their reflections in a much wider field." 778 Palestine had become a powder keg that threatened the whole international community.

In closing, Bevin voiced the British government's commitment to fulfill its obligations as the Mandatory power in Palestine. In doing so, he signaled to the Americans that authority for Palestine would remain firmly in British hands and warned that Palestine was not a problem that could be resolved by force of arms. More importantly, it would be settled through conciliation and discussion. Any attempt to use violence or encourage the use of violence would be viewed by the British government as a "breach of faith" that would affect the disposition of the outcome. In other words, Bevin and the British would brook no interference from American Zionists.

Over the next few months, MacCallum paid greater attention to the growing influence of international Zionist lobbying, which in her view had caused cleavages in government bureaucracies and threatened the effectiveness of decision-making. On December 10, 1945, MacCallum presented the department with a précis of the proceedings of a special debate on Palestine, which had recently taken place in the British

\footnotetext{
${ }^{777}$ Ibid.

${ }^{778}$ Ibid.
} 
House of Lords. Her examination captured the competing impulses of Zionist and antiZionist forces in Britain. ${ }^{779}$ While the Foreign and Colonial Offices were decidedly antiZionist, MacCallum witnessed significant elements in the United Kingdom that remained sympathetic to the Zionist cause. Her report paid particular attention to the speeches of Viscount Herbert Samuel, a former high commissioner to Jerusalem, and Viscount Cranborne, former secretary of state for dominion affairs. Her analysis noted that Samuel, an ardent Zionist, had strongly defended Zionist rights in Palestine, and repudiated the Arab rights and claims to Palestine. ${ }^{780}$ Only Jews, he declared, had been promised Palestine in the Balfour Declaration and the Palestine Mandate agreement of 1922. Both of these declarations, he contended, were internationally recognized. Consequently, he called on the British government to repudiate the White Paper of 1939. Samuel, however, stopped short of calling for an independent Jewish state in Palestine, remarked MacCallum. With the present ratio of the population, he reasoned, "“it was impossible to have a Jewish state." ${ }^{781}$ Instead, Samuel insisted that Palestine should be put under an International Trusteeship for some years, as Roosevelt had insisted in early 1945.

In contrast, Lord Cranborne's statement focused on the root causes of the current violence in Palestine - the Jewish Agency's agitation and propagandistic activities in the United States and Britain. He asserted that the Agency had not only succeeded in

779 Elizabeth MacCallum, "Palestine and the Jews of Europe," December 10, 1945, External Affairs Records, LAC, RG 25, Vol. 1839, Part 3.

${ }^{780}$ Ibid, p. 2. Viscount Samuel's central argument was that Britain had never promised Palestine to the Arabs, since it was not included in the McMahon letter. Also see: Viscount Samuel, "Alternatives to Partition," Foreign Affairs, Vol. 16, No. 1 (October, 1937), pp. 143-155.

${ }^{781}$ Ibid, p. 3. 
inflaming the situation and risked destroying "the work of the Commission before it was begun" but had inspired the extreme supporters of Zionism. ${ }^{782}$ Cranborne appealed for a policy that would "harmonize the aims and aspirations of two mutually mistrustful communities and weld them into one nation." $" 783$ Thus, he promoted the idea of a binational state.

While MacCallum recognized how influential and divisive political Zionism was in Britain, it was the Zionist influence in the White House that concerned her the most. ${ }^{784}$ The two ardent champions of the Jewish cause on the White House staff, stated historian David McCullough, were Clark Clifford, White House Counsel, and David K. Niles, Truman's special assistant for minority affairs. "Niles and Clifford would keep key Zionists informed of what was going on in Washington and within the White House at almost every step." ${ }^{785}$ It was through the efforts of Niles that the Zionists made their strongest gains in the White House. He created an intelligence network wholly independent of the State Department, through which the Zionists could "provide the President with information on conditions in Palestine, negotiations between Britain and the Jewish Agency, opinions in the United Nations, and complicity between U. S. and British diplomats in trying to scuttle the President's policy." ${ }^{786}$ Niles also effectively

\footnotetext{
782 Ibid, p. 5.

783 Ibid.

${ }^{784}$ Elizabeth MacCallum, "United States Policy on Palestine," August 30, 1946, External Affairs Records, LAC, RG 25, Vol. 3831, File: 8903-40, Part 1, p. 1. Also see; King Diaries, February 13, 1944. King met with German author Emil Ludwig, who warned the prime minister of the growing Zionist influence in the White House.

${ }^{785}$ McCullough, Truman, p. 596.

786 Joseph A. Pita, "Interest Groups and the White House under Roosevelt and Truman," Political Science Quarterly, Vol. 102, No. 4 (Winter, 1987-1988), p. 657. For further detail, see: John B. Judis, Genesis:
} 
countered "State Department arguments and strategies detrimental to the Jewish cause while devising gambits of his own." This left a cleavage between the State Department and the White House, the latter shaping the president's pro-Zionist perceptions of the situation. Consequently, the State Department's influence on the key decisions regarding the Palestinian question was neutralized.

MacCallum recognized similar Zionist efforts to influence Canada's position on Palestine and publicly influence King's government into supporting their cause. Throughout 1945 and 1946, she had witnessed the renewed efforts by pro-Zionist forces to recruit government officials, and target individual members of the governing party, who could be used to draw out the Canadian government publicly to support Zionism. One such example was the newly appointed Liberal senator, Arthur Roebuck. In a January 27, 1946 speech delivered at Massey Hall in Toronto, Roebuck challenged the federal government's and the prime minister's positions on Palestine. ${ }^{787}$ In a distasteful diatribe, Roebuck derided both the Arabs and British for trying to destroy the Jewish community in Palestine. The Arabs, he roared, would destroy the Jewish settlement if they could. "They would deport the Jews from Palestine, or render them politically impotent. . ...788 As for the British, Roebuck suggested that they had been largely responsible for the Jewish Holocaust. ${ }^{789}$ "Had Great Britain vigorously promoted Jewish

Truman, American Jews, and the Origins of the Arab/Israeli Conflict (New York: Farrar, Straus, and Giroux, 2014).

787 Arthur W. Roebuck, "Palestine: A Cross-World Route and War," January 27, 1946, External Affairs Records, LAC, RG 25, Vol. 3831, File: 8903-40, Part 1, p. 1.

${ }^{788}$ Ibid, p. 4.

${ }^{789}$ Ibid, p. 3. 
immigration to Palestine instead of limiting it as a concession to the Arabs," declared Roebuck, "there would have been a different tale to tell in the second great war." ${ }^{790}$ His statement implicitly questioned why the Canadian government had left the fate of the Jewish people in Palestine to the British.

Soon MacCallum became a target of Zionist attention. Zionist organizations in Canada understood the importance of her role - she was the co-ordinator of Canadian thinking on Palestine, such as it was. Most of the briefings on Palestine and the Jewish question that the prime minister received were in whole or part handled by her. Therefore, the various pro-Zionist organizations and Jewish community leaders focused resources on getting MacCallum's support or neutralizing her influence. They sent her books, statements, and petitions that promoted or defended particular Zionist positions. ${ }^{791}$ This attention was reflected in her May, November, and December meetings with Samuel Zacks, president of the Zionist Organization of Canada. ${ }^{792}$

The Zionists also tried to circumvent MacCallum by lobbying the prime minister directly. The Jewish leadership recognized that it was the prime minister and Cabinet that

790 Ibid.

791 Elizabeth MacCallum, “Letter to Harry Batshaw," July 11, 1946, External Affairs Records, LAC, RG 25, Vol. 3831, File: 8903-40, Part 1. In this letter MacCallum thanked Harry Batshaw, a Montreal lawyer, who served as the head of the National Council of the United Zionist Council, for his letter of June 21, 1946, that provided her with “an abbreviated account of Dr. [Chaim] Weizmann's speech of June 18th . . .."Her letter added that "If I should be here when you are in Ottawa again I should be glad to have you ring me if you are not too busy."

792 See: Bercuson, Canada and the Birth of Israel, p. 29. Also see: Elizabeth MacCallum, "Note for Mr. Pearson," November 15, 1946, External Affairs Records, LAC, RG 25, Vol. 3831, File: 8903-40, Part 1, pp. 1-3; "Note for Mr. Pearson," November 29, 1946, External Affairs Records, LAC, RG 25 , Vol. 3831, File: 8903-40, Part 1, pp. 1-2. 
ultimately determined policy; ${ }^{793}$ therefore, they needed to appeal directly to King. In a March 14, 1946 letter to Mackenzie King, for example, Zacks questioned why the prime minister had failed to live up to his promises to the Jewish people. Zacks insisted that Canada had made a commitment to the creation of a Jewish state in Palestine by way of its vote in the League of Nations on the Palestine Mandate and the government's decision not to support publicly the 1939 White Paper on Palestine. ${ }^{794}$ He further suggested that a majority of Canadians supported Zionist aims. According to a Canadian Gallup Poll, he pointed out, 47 percent of Canadians favored free immigration of Jews to Palestine and only seven percent were opposed. ${ }^{795}$ "It was apparent," suggested Zacks, "that there is only $7 \%$ of Canadians who are favorable to the consummation of the White Paper policy which, if allowed its logical development, will cut off all Jewish immigration to Palestine." 796

Arab interest groups, such as the Canadian-Arab Friendship League (CAFL), also lobbied the department and the prime minister's office. The CAFL was only one of several interest groups that petitioned the Canadian government on behalf of the Arabs. The Anglo-Arab Friendship Society in London ${ }^{797}$ and the Arab Office in Washington D.

\footnotetext{
793 Abella and Troper, None is Too Many, p. 209.

${ }^{794}$ Samuel Zacks, "Letter to the Prime Minister," March 14, 1946, External Affairs Records, LAC, RG 25, Vol. 3831, File: 8903-40, Part 1, pp. 1-2.

${ }^{795}$ Ibid, p. 1.

${ }^{796}$ Ibid.

${ }^{797}$ Francis Newton, "Anglo-Arab Friendship Society Memorandum on the Palestine Problem to the United Nations," April 21, 1947, External Affairs Records, LAC, RG 25, Vol. 3694, File: 5475-CD- 40C, Part 1 .
} 
C. were also both active in lobbying MacCallum and the department. ${ }^{798}$ Former State Department officials, now working for oil companies like ARAMCO, assisted the Arabs in shaping their anti-Zionist campaign. These well-connected and savvy American professionals were instrumental in honing the Arab message and coaching them in how to create a favourable public opinion and influence policymakers. ${ }^{799}$ Foreign Office officials were more direct in their support. They quietly passed to the Arabs memoranda that methodically laid out the Arab grievances. These documents helped the Arabs effectively promote the justice of their legal case.

While less skilled in the art of diplomatic persuasion, the western consultants helped the Arab groups favourably impress key players in the Canadian government. The Arabs made a strong and cogent argument for King to support the 1939 White Paper policy. ${ }^{800}$ They insisted that unrestricted Jewish immigration in Palestine denied them the principles of justice and equality; their democratic rights would be violated, and the concept of self-determination - the bedrock of Wilsonian internationalism - would forever be seen as an empty promise made by western and imperialist powers. ${ }^{801}$

\footnotetext{
798 The Arab Office published a monthly journal, Arab News Bulletin, which was issued to every western mission as well as the United Nations. Several copies are present in the DEA's archived records. See: External Affairs Records, LAC, RG 25, Vol. 3831, File: 8903-40, Part 1.

${ }^{799}$ Michael Cohen, "William A. Eddy, the Oil Lobby and the Palestine Problem," Middle Eastern Studies, Vol. 30, No. 1 (January, 1994), pp. 167-169.

${ }^{800}$ M. S. Massoud, I Fought as I Believed (Montreal: Ateliers Des Sourds Inc., 1975), p. 15.

${ }^{801}$ L. B. Grafftey Smith, "British Ambassador in Jeddah to the Secretary of State for External Affairs," February 20, 1946, External Affairs Records, LAC, RG 25, Vol. 3831, File: 8903-40, Part 1, pp. 1-2. Also see: Phillip K. Hitti, "Zionist Claims and Arab Rights," World Affairs, Vol. 109, No. 1 (March, 1946) External Affairs Records, LAC, RG 25, Vol. 3831, File: 8903-40, Part 1, pp. 1-3.
} 


\section{The Anglo-American Report and MacCallum's Responses}

The character and substance of the discourse regarding Palestine and the Jewish refugee crisis changed dramatically with the release of the Anglo-American Committee of Enquiry on Palestine Report, ${ }^{802}$ the result of 120 days of hearings in Washington, London, Vienna, Cairo, and Jerusalem. The recommendations of the 40,000 word, 64page report were designed to be "integral parts of a single whole, with concessions to one side balanced against the concessions to the other." 803 The proposals called for the international community to find homes outside of Palestine for the Jewish refugees and displaced persons; for the immediate admission of 100,000 Jews to Palestine; for Palestine to be transformed into a binational state with autonomous Arab and Jewish provinces; for Palestine to continue to be governed under the present Mandate, pending a United Nations-approved Trusteeship agreement; for the Mandatory power to continue to administer immigration and ensure rights were protected; for the land transfers regulations of 1940 to be rescinded and replaced by unrestricted transfers; for an examination, discussion, and execution of an economic development plan in consultation with the Jewish Agency and governments of neighbouring Arab states; for a general improvement in Arab education and standard of living; and, for the Jewish Agency to

\footnotetext{
${ }^{802}$ Lester B. Pearson, "Canadian Ambassador to Washington to Secretary of State for External Affairs," May 2, 1946, External Affairs Records, LAC, RG 25, Vol. 5745, File: 47-B (s), Part 1. See attachment: State Department, "Report of Anglo-American Committee of Enquiry on Palestine," No. 103. Also see: "The Report of the Anglo-American Palestine Committee," Chronology of International Evens and Documents, Vol. 2, No. 9 (April 22-May 5, 1946), p. 265. The report contained ten recommendations, comments, and appendices that dealt with the itinerary of the Committee, the position of Jews in various European countries, the estimated Jewish population in Europe, the historical background of Palestine, public security in Palestine, and the text of the Palestine Mandate of 1922.

${ }^{803}$ Evan Wilson, "The American Interest in the Palestine Question and the Establishment of Israel," Annals of the American Academy of Political and Social Science, Vol. 401, America and the Middle East (May, 1972), p. 68.
} 
resume immediately co-operation with the Mandatory power in the suppression of terrorism, illegal immigration, and the maintenance of law and order throughout Palestine. ${ }^{804}$

On July 26, 1946, following the completion of the Anglo-American inquiry, Canadian officials were presented an aide mémoire by P. A. Clutterbuck, the British high commissioner to Canada. ${ }^{805}$ The document provided an advanced summary of and response to the Anglo-American Committee Report. In addressing the Anglo-American Committee's proposal for the immediate immigration of 100,000 Jews into Palestine, the high commissioner's three-page letter requested that the Canadian government take in a portion of the Jewish displaced persons from Europe:" 806 "It seems essential, if Arab opposition . . . is to be overcome, ${ }^{\prime 807}$ for Canada and other countries to demonstrate to the Arabs that they would not bear the burden of immigration alone. The British high commissioner further requested that the prime minister make a public statement, before the end of July 1946, declaring his government's support for the United Nations' call for all member states to receive a portion of displaced persons from Europe. More

\footnotetext{
804 "The Report of the Anglo-American Palestine Committee," pp. 266-268. Also see: Jewish Agency for Palestine, Memorandum Submitted to the Anglo-American of Inquiry on Palestine (Jerusalem: Jewish Agency for Palestine, March 1946).

${ }^{805}$ Great Britain, “Aide Mémoire,” July 26, 1946, External Affairs Records, LAC, RG 25, Vol. 5745, File: 47.B (S), Part 1, pp. 1-3.

806 The aide mémoire included a letter from the British High Commissioner and an 11-page draft announcement of Anglo-American agreement on the Committee of Inquiry's findings. The draft announcement also included a 28-point plan, which fleshed out the aims and methods for implementing the recommendations of the Anglo-American Committee Report.

${ }^{807}$ Great Britain, “Aide Mémoire letter,” p. 1.
} 
importantly, Clutterbuck wanted the prime minister publicly to declare the number of Jewish displaced persons that his government would take in. ${ }^{808}$

Within days of receiving the British aide mémoire, Hume Wrong, the acting under-secretary of state for external affairs, wrote Louis St. Laurent, the acting prime minister, informing him of Clutterbuck's request. Ever blunt, Wrong insisted that, in his judgment, the British dispatch had suggested that Canada was not doing its fair share in alleviating the refugee crisis, and in particular, meeting the Jewish problem. ${ }^{809}$ Wrong believed the Americans and British were, in effect, trying to cajole or strong-arm Canada and the other Commonwealth Dominions into accepting Jewish refugees and displaced persons from Europe. ${ }^{810}$ Wrong was particularly irritated that Britain wanted Canada to protect Britain's interests in Palestine, and that Canada was being used to counter American demands to open Palestine to the Jews. The acting under-secretary seriously doubted that "Cabinet would solve British problems by creating Canadian ones." $" 811$ Wrong concluded that: "We shall have to give some reply in writing." 812 However, without a clearly defined policy on Palestine or the Jewish refugee problem, ${ }^{813}$ Wrong conceded that Canada needed to build a better foundation of understanding for the

\footnotetext{
808 Ibid.

${ }^{809}$ See “Aide Mémoire: Draft Public Statement," p. 2. The document stated that Britain had already taken in 70,000 Jews and was prepared to accept 225,000 Polish troops, dependents, and their dependents. It also noted that the United States have already resettled 275,000 refugees, including 180,000 Jews, and was prepared to accept another 53,000 European immigrants.

${ }^{810}$ Hume Wrong, "Memorandum for Mr. St. Laurent," July 29, 1946, External Affairs Records, LAC, RG 25, Vol. 5745, File: 47-B (s), Part 1, p. 1.

811 Abella and Troper, None is Too Many, p. 204.

${ }^{812}$ Wrong, "Memorandum for Mr. St. Laurent," p. 2.

813 R. G. Riddell, "Memorandum by Second Political Division," January 3, 1946, in Document on Canadian External Relations (DCER), Vol. 12, 1946 (Ottawa: Supply and Services Canada, 1977), p. 353.
} 
government's response to the two problems. He asked MacCallum, in whom he placed confidence, to prepare a series of responses and working papers addressing Canada's efforts regarding refugees and displaced persons, and the key issues surrounding the Anglo-American dispute over Palestine.

On July 31st, in the first of three working papers, entitled: "Statement on Displaced Persons and Palestine," MacCallum described the contributions that Canada had already made to the international refugee problem. Since the beginning of the war, she argued, Canada had done its part in addressing the refugee crisis. Between 1939 and the end of hostilities in 1945, Canada had admitted 3,500 European refugees. Under Privy Council (P. C.) Order 6687 of October 26, 1945, refugees had been given permanent status. As a further contribution, MacCallum declared, the Canadian government had enacted P. C. Order 2071 on May 28, 1946, which broadened "the classes of persons admissible to Canada." ${ }^{814}$ MacCallum added that, on July 25, 1946, the government had authorized the admission, on a conditional basis, of 4,000 veterans of the Polish Army who served with Allied forces. These initiatives, argued MacCallum, had shown the government's "willingness to play its part in solving the problems of refugees and displaced persons. . .."815

\footnotetext{
814 MacCallum, "Statement on Displaced Persons and Palestine," p. 2. Also see: M. G. Glassco, "Preliminary Report of Interdepartmental Committee on Immigration Policy to the Cabinet Committee on Immigration," April 4, 1946, in DCER, Vol. 12, 1946, p. 355; R. G. Riddell, "Secretary of State for External Affairs to Acting High Commissioner in Great Britain," July 3, 1946, in DCER, Vol. 12, 1946, pp. 358-359.

${ }^{815}$ Ibid.
} 
MacCallum further advanced the argument that the government's international efforts had been equally constructive. At recent international conferences, Canadian delegations had consistently supported the principle that the problem of Jewish and nonJewish refugees and displaced persons could only be dealt with on a broad international basis, with many countries collaborating in succouring and receiving the victims of war and persecution. ${ }^{816}$ This approach was particularly evident, explained MacCallum, "during recent meetings of the General Assembly of the United Nations, the Economic and Social Council, the Council of U.N.R.R.A., the Inter-Governmental Committee on Refugees, and the Special Committee on Refugees and Displaced Persons established by the General Assembly. ${ }^{" 17}$ Canada would continue, she asserted, to be internationally and domestically engaged in the problems of displaced persons and refugees.

In the second part of her memorandum, MacCallum addressed the aide mémoire's proposed architecture for a new binational Palestine, and Canada's attitude towards it. She contended that, in principle, the Canadian government ought to support the AngloAmerican Committee's recommendation that:

Palestine should be neither a Jewish nor an Arab state; neither community should dominate the other; the form of government to be established should protect the interests in the Holy Land of Christendom and of the Moslem and Jewish faiths. ${ }^{818}$

By supporting the proposal, MacCallum made clear that the Canadian government was prepared to assist equally Arabs and Jews in constructing an independent state, a state

\footnotetext{
${ }^{816}$ Ibid.

${ }^{817}$ Ibid, p. 1.

${ }^{818}$ Ibid.
} 
where the Arab and Jewish provinces would exercise an equal degree of autonomy, while foreign affairs, defence, and customs and excise, would continue to be administered by a central government.

On immigration, MacCallum concurred with the Committee's recommendation that the Mandatory power should oversee its operation, while the provinces would administer it. The Jewish province, asserted MacCallum, would be entitled to admit 100,000 Jewish refugees from Europe immediately, and thereafter, to receive what newcomers it desired. The Canadian government, recommended MacCallum, should support the replacement of the Palestine Mandate with a Trusteeship agreement, after consultation with the respective parties to the agreement. She urged Canadian Arabs and Jews to throw their support on the side of "moderation and reason and against the dissemination of inflammatory propaganda." ${ }^{819}$

On the surface, MacCallum's "Statement on Displaced Persons and Palestine" appears to have been constructed to refute the British accusation that Canada had not pulled its weight in addressing the international refugee problem. On a closer inspection, however, it can be argued that her study was intended to discredit domestic and political criticisms of Canada's postwar immigration and refugee policies. MacCallum's report effectively used a series of largely administrative actions — redefining resident status' and broadening classes for immigrant admissions - as evidence of Canada's commitment and contributions to resolving the Jewish refugee problem, even though

\footnotetext{
${ }^{819}$ Ibid, p. 3.
} 
none of the 3,500 European refugees or 4,000 Polish soldiers who had been taken in were Jewish. MacCallum's study also suggested, erroneously, that Canada took a leading role in establishing international mechanisms for resolving the refugee problems. She had written what the government expected: a justification of a restricted immigration policy, one that particularly restricted Jewish immigration. ${ }^{820}$ The paper was distributed throughout the department and was part of the government's formal response to the British aide memoire.

On August 2, 1946, MacCallum's second memorandum, "Background of Discussions on Palestine," was presented to Hume Wrong and the acting prime minister. MacCallum's survey of Anglo-American relations regarding Palestine came on the heels of her "Statement on Displaced Persons and Palestine." Her second study, however, embodied her concerns about growing Anglo-American differences, and the everworsening situation in Palestine. There was little doubt in her mind that, by the summer of 1946, Palestine had become a seriously divisive issue between the British and Americans. This concern became apparent in MacCallum's assessment of the AngloAmerican Committee's findings, contained in her "Background" memorandum.

MacCallum's study focused almost exclusively on the strategic implications of three of the report's most contentious recommendations:

A) The first recommendation called for an effort to find new homes outside of Europe elsewhere than in Palestine for certain classes of displaced persons, regardless of creed or nationality, and to safeguard the

\footnotetext{
${ }^{820}$ Abella and Troper, None is Too Many, p. 204.
} 
position of the great majority of European Jews who will continue to live on the continent.

B) The second recommendation called for the immediate granting of 100,000 Palestine immigration certificates to Jews in assembly centers in Germany and Austria.

C) The third recommendation called on the Jewish Agency to resume at once active co-operation with the Mandatory power in suppressing terrorism and the legal immigration and in maintaining law and order. ${ }^{821}$

It is important to note that MacCallum's August study was not intended to be anything more than an overview of Anglo-American positions and their apparent disagreements over Palestine and the Jewish refugee crisis. Nor was it meant to provide External Affairs officials with a comprehensive assessment of the Anglo-American Committee's report, or to propose any particular Canadian position regarding the Committee's findings.

Why then did MacCallum focus her attention exclusively on these three recommendations? Were they more noteworthy than the other seven proposals? We can speculate that her comments reflected her concern about the risk of the three recommendations' imminent implementation, and the immediate effect that they could have on Canadian domestic and foreign policy.

For MacCallum, the recommendation for finding new homes for Jewish refugees and displaced persons represented a serious domestic problem for the Canadian government. The proposal recalled MacCallum's warnings that Canada would be hard pressed by the United States and Britain to admit a significant number of refugees and displaced persons. ${ }^{822}$ She had already witnessed a similar effort in $1944,{ }^{823}$ and knew it

\footnotetext{
${ }^{821}$ MacCallum, "Background of Discussions on Palestine," p. 2.

${ }^{822}$ MacCallum, "Palestine: Postwar Policy," and the "Statement on Displaced Persons and Palestine."
} 
was only a matter of time before international humanitarian organizations and the Great Powers pushed Canada to take a larger share of Jewish refugees and displaced persons. ${ }^{824}$ These demands would ultimately lead domestic interest groups, such as the Zionist Organization of Canada, to demand the unification of Jewish families in Canada, ${ }^{825}$ and even further expand the Jewish community in Canada. Yet she was also aware that King and his cabinet would strongly resist efforts to increase admissions of refugees and displaced persons. Expanded immigration ran contrary to the prime minister's principal postwar responsibility of ensuring that Canada's economy did not slide into an economic recession, as had occurred after World War I. The influx of new refugees and displaced persons threatened this goal. This would almost certainly derail his plan of creating a "smooth and gradual reabsorption of the Canadian military into civilian life" before immigration matters could be considered. ${ }^{826}$

Putting economic considerations aside, the prime minister was well aware that the public was strongly divided over the issue of Jewish immigration. As noted by Abella and Troper, there was a 'lurking hostility to 'foreign' immigrants,' particularly eastern Europeans and, most particularly, Jews." 827 This was especially evident in largely

\footnotetext{
${ }^{823}$ For a detailed discussion, see: Abella and Troper, None is Too Many, pp. 177-180.

${ }^{824}$ Riddell, "Memorandum by Second Political Division," p. 354. Riddell's memorandum predicted that as soon "as a group of permanent exiles begins to emerge from the mass of displaced persons in Europe and transportation across the Atlantic becomes available for civilian passengers, the question of finding homes for refugees in the American hemisphere will almost certainly confront Canadian representatives on international humanitarian bodies."

${ }^{825}$ Ibid.

${ }^{826}$ Abella and Troper, None is Too Many, p. 197. Also see: King Diaries, February 13, 1944; R. G. Riddell, "Memorandum by Second Political Division," January 3, 1946, in DCER, Vol. 12, 1946, p. 355.

${ }^{827}$ Ibid, p. 198.
} 
Catholic Quebec, where strong attitudes about on the matter existed. ${ }^{828}$ There were indeed many Canadians, maintained historian Donald Avery, "who warned that the country could not afford the luxury of accepting 'unproductive' immigrants or those who could not easily assimilate." ${ }^{829}$ Even advocates of a liberalized immigration policy were at odds over who should be allowed into Canada, and, more importantly, in what numbers. ${ }^{830}$ This was made worse by an immigration bureaucracy that insisted its principal duty was to guard Canada's gates from undeserving refugees. ${ }^{831}$ MacCallum recognized this sentiment and believed that the domestically sensitive prime minister would do little to challenge the negative public opinion surrounding Jewish immigration even if the Great Powers pressed him.

MacCallum was convinced that the immediate granting of 100,000 Palestine immigration certificates was the most alarming of the Committee's recommendations. She knew that, if granted, this recommendation would dramatically worsen AngloAmerican tensions and provoke an already restive Arab World. MacCallum's apprehensions were confirmed when Truman made a public statement following the release of the Committee's report. In his April 30, 1946 press release, the president declared that:

\footnotetext{
${ }^{828}$ Norman Hillmer and J. L. Granatstein (eds.), The Land Newly Found: Eyewitness Accounts of the Canadian Immigrant Experience (Toronto: Thomas Allen Publishers, 2006), p. 12.

829 Donald Avery, Reluctant Host: Canada's Response to Immigrant Workers, 1896-1994 (Toronto: McClelland \& Stewart Inc., 1995), pp. 144-145.

${ }^{830}$ Abella and Troper, None is Too Many, p. 231.

831 Harold Troper, “Canada’s Immigration Policy since 1945," International Journal, Vol. 48, No. 2, Migrants \& Refugees (Spring, 1993), p. 259.
} 
I am very happy that the request which I made for the immediate admission of 100,000 Jews into Palestine has been unanimously endorsed by the Anglo-American Committee of Inquiry. . . . I am also pleased that the Committee recommends in effect the abrogation of the White Paper of 1939 including existing restrictions on immigration and land acquisition to permit the future development of the Jewish National Home. It is also gratifying that the report envisages the carrying out of large-scale economic development projects in Palestine, which would facilitate further immigration and be of benefit to the entire population. ${ }^{832}$

Truman's pronouncement was blunt, prejudicial, and contemptuous of Arab rights and British authority. It must have seemed a dangerous misstep to MacCallum. Whether or not his comments were only intended for a domestic audience, Truman's remarks unleashed an immediate firestorm in Britain and the Middle East.

As MacCallum had anticipated, the British reacted rapidly and angrily to Truman's statement. British Foreign Secretary Ernest Bevin "was in a black rage because Truman had chosen to pluck one recommendation out of the report and feature it." 833 The following day, the wrath of the British House of Commons was unleashed. Publicly chiding Truman, Prime Minister Attlee declared that the Anglo-American report "must be considered as a whole in all its implications. $"{ }^{834}$ In effect, the prime minister had scolded Truman for "cherry picking" from the committee's findings. Attlee concluded that

${ }^{832}$ Dean Acheson, "Acting Secretary of State to Secretary of State," April 30, 1946, in Foreign Relation of the United States (FRUS), 1946, Vol. 7, The Near East and Africa (Washington, D. C.: Government Printing Office,1969), p. 589. On April 28, 1946, Bevin expressed the hope to the American secretary of state, James Byrnes, that the United States would not make a statement of policy on Palestine without consulting with the British government. Truman refused the British request.

${ }^{833}$ Herbert Feis, The Birth of Israel: The Tousled Diplomatic Bed (New York: W. W. Norton \& Company, 1969), p. 28.

${ }^{834}$ Averell Harriman, "U. S. Ambassador in the United Kingdom to Secretary of State," May 1, 1946, in FRUS, 1946, Vol. 7, p. 589. 
"Britain would not permit large-scale Jewish immigration into Palestine unless the Zionists disbanded their underground armed forces and ended their terrorism." $" 835$

The Arab response to Truman's statement was equally hostile. In a May 3, 1946 memorandum addressed to the U. S. secretary of state, Pinkney S. Tuck, the ambassador to Cairo, reported that "he had been besieged by representatives of every Arab state." Arab newspapers criticized Truman's widely-printed remarks, added Tuck. According to Cairo dailies, the president's statement revealed America's true intentions in Palestine. In discussing the matter with Tuck, Azzam Pasha, the secretary general of the Arab League, declared, "America had shown that it was now an enemy" to the Arabs. ${ }^{837}$ Pasha further added that the report gave the Zionists the essentials of a Jewish state — immigration and the right to purchase unlimited land — while denying Arabs the right to control their own immigration and land transfers. It was a repudiation of all Arab rights. ${ }^{838}$ Less than a week later, George Wadsworth, the American ambassador to Syria and Lebanon, made a similar report to the secretary of state. He reported that "the reaction in press, public and official circles has been disillusionment, hardening into determination to resist implementation of [the] Commission's recommendations." 839 Wadsworth recounted that Emir Feisal of Saudi Arabia accused Truman of being a pro-Zionist, "whose attitude was

\footnotetext{
${ }^{835}$ Feis, The Birth of Israel, p. 28.

${ }^{836}$ Pinkney S. Tuck, “U. S. Ambassador in Egypt to Secretary of State,” May 3, 1946, in FRUS, 1946, Vol. 7, pp. 592-593.

837 Ibid.

838 Ibid

${ }^{839}$ George Wadsworth, "Memorandum for the Secretary of State," May 9, 1946, in FRUS, 1946, Vol. 7, p. 599.
} 
shocking to all those who had long counted on [America's] erstwhile seeming ardor to implement principles of international justice in [the] postwar world." 840

In a May 1st New York Times article, which undoubtedly found its way to MacCallum, James Reston reported that:

The President's comment on the report was considered in the embassies to be of more importance than the report itself, since the committee of inquiry merely had the power of recommendation, while the President's comment is regarded as a statement of United States policy. ${ }^{841}$

According to various publications in the Arab and Muslim Worlds, Americans, and Truman in particular, were accused of conspiring with American Zionists to steal Palestine from its rightful owners. These antagonistic sentiments were not limited to the British and Arabs. Georges Vanier, the Canadian ambassador to France, and Paul Malone, the speaking for the acting Canadian high commissioner to Australia, described similar criticisms emanating from Paris and Canberra. ${ }^{842}$ To drive home the dangers emanating from the Arab World, MacCallum distributed throughout the department a copy of a May 10, 1946 essay, which appeared in the British journal The Spectator. Written by Edward Atiyah, an Anglo-Lebanese political activist, "Palestine: An Arab View" reported that the leaders of the Arab World were convinced that the AngloAmerican Committee had been co-opted by American Zionists into approving the 100,000 immigration certificates. "The issue," claimed Atiyah, "had been prejudged and

\footnotetext{
840 Ibid.

841 James Reston, “Truman Comment Arouses Concern,” New York Times, May 1, 1946, p. 13.

${ }^{842}$ Georges P. Vanier, "Canadian Ambassador to Paris to Secretary of State for External Affairs," May 24, 1946, External Affairs Records, LAC, RG 25, Vol. 3831, File: 8903-40, Part 1; Paul Malone, "[For] Acting-Canadian High Commissioner to Australia to Secretary of State for External Affairs," June 5, 1946, External Affairs Records, LAC, RG 25, Vol. 3831, File: 8903-40, Part 1, pp. 1-2.
} 
determined even before the Committee was formed." He suggested that the Committee's recommendations were a complete denial of Arab rights. ${ }^{843}$

MacCallum agreed with many of Atiyah's criticisms. She was convinced that the American administration had bent over backwards to appease American Zionists. As she noted in "Background of Discussions on Palestine," Truman had "welcomed the features which were most pleasing to Zionists and promised to take 'under advisement' those which they might be expected to oppose." ${ }^{\prime 44}$ She undoubtedly saw the recommendation to allow 100,000 Jews into Palestine as violating the spirit, if not the letter, of the United Nations Charter. It directly contravened Articles 73, 74, 76(b). ${ }^{845}$ According to these provisions, United Nations member states, and especially permanent members of the Security Council, were honour-bound to respect and base their policies regarding Trusteeship on the principles of good neighbourliness, ensuring the well-being of the people, and advancing the wishes of the people. MacCallum without a doubt believed that, without Arab consent, the introduction of 100,000 Jewish refugees into Palestine violated the UN's stated goals of maintaining international peace and security.

\footnotetext{
843 Edward Atiyah, "Palestine: An Arab View," The Spectator, May 10, 1946. A copy of Atiyah's article was found in External Affairs Records, LAC, RG 25, Vol. 3831, File 8903-40, Part 1, pp. 1-3. and approved for distribution by MacCallum.

${ }^{844}$ MacCallum, "Background of Discussions on Palestine," p. 2.

${ }^{845}$ Charter of the United Nations. Article 73 held "States responsible for administering dependent territories recognize that the interests of the dependent peoples are a primary concern and accept the obligation to promote their well-being ...." Article 74 stated that: "the members also agreed to base their policy with respect to dependent territories on the principle of good neighborliness, taking due account of the interests and well-being of the other members of the world community and social, economic, and commercial matters." In outlining the basic objective of the Trusteeship system, Article 76(b) used the words "to promote the advancement of dependent peoples and their development towards selfgovernment or independence in accordance with their particular circumstances, the wishes of the peoples, and the terms of the subsequent Trusteeship agreements."
} 
MacCallum also knew that the recommendation, if implemented, would further de-stabilize the fragile politics of Palestine and its Arab neighbourhood. ${ }^{846}$ Arab leaders had already made their position plainly known. They would go to war with the Zionist interlopers before they would accept a Jewish state in Palestine. ${ }^{847}$ MacCallum was sure that the recommendation's formal adoption by Canada would discredit the country in the eyes of the Arab and Moslem Worlds, making it impossible for Ottawa to mediate in any future Arab-Jewish conflict. More importantly, the plan would do little to mend the Anglo-American divide.

MacCallum's third worry about the Anglo-American Committee Report centered on the recommendation which insisted that the Jewish Agency co-operate with British authorities in suppressing terrorism in Palestine; that is, preventing illegal Jewish immigration and maintaining law and order. When the Anglo-American Committee of Inquiry reached Jerusalem on March 6, 1946, to conduct its interviews, it found that the attitudes of Arabs and Jews were dominated by extremist viewpoints. Therefore, the recommendation seemed untenable. It was obvious to British delegation officials that something had to be done to curtail or diminish the Agency's actions and authority. Since 1945, the Jewish Agency, in association with Haganah, an illegal Jewish paramilitary force formed to protect Jewish settlers, ${ }^{848}$ and Irgun Zvai Leumi, a Zionist extremist

\footnotetext{
${ }^{846}$ MacCallum, “Palestine: Postwar Policy,” C214548.

847 Wadsworth, "Memorandum for Secretary of State," p. 599. Wadsworth reported that Emir Feisal, the Saudi Arabian foreign minister, had asserted that: "I am afraid we Arabs will have to resist, by force if necessary. ...."

${ }^{848}$ Hurewitz, The Struggle for Palestine, p. 239: Haganah "had been forged during the war into a wellorganized illegal army of an estimated 60,000 troops, with the striking force, a static defense force, and reservists." To these units belonged most of the enlistees in the Jewish brigade in various branches of
} 
military organization, had carried out numerous anti-British operations in Palestine, such as the destruction of the Palestine's railroad network, radar installations, police stations, and bridges. ${ }^{849}$ Bevin's biographer, Alan Bullock, stated that:

The Haganah not only cooperated with the extremist groups in raids on police and army installations but resumed illegal immigration on an increased scale: both were intended as a challenge to the British authorities and a provocation to take action which could then be blazed into the world as persecution in a Nazi-style British police state. ${ }^{850}$

Given the fact that the Jewish Agency and the British government were on irreconcilable courses, it must have seemed impossible to MacCallum that a peaceful accommodation could be reached between the two. ${ }^{851}$ Such an assessment was bolstered by the British high commissioner's warning to Mackenzie King that “His Majesty's government in the United Kingdom has come to the conclusion that drastic action can no longer be postponed." ${ }^{" 852}$ Following British intelligence sources, the high commissioner declared that Zionists in Palestine were "acquiring large supplies of arms, most of them with money furnished by American Jews. ${ }^{" 853}$ London was especially concerned that the proposed influx of Jewish refugees would soon provide the Zionists' private armies with

the British Armed Forces, which were gradually being mobilized. Moreover, the equivalent of one year's compulsory military training for high school seniors was inaugurated in November 1945. The considerable military supplies acquired in the war years had been distributed throughout the community."

${ }^{849}$ Feis, The Birth of Israel, p. 22.

${ }^{850}$ Bullock, Ernest Bevin, p. 254.

${ }^{851}$ MacCallum, "Background of Discussions on Palestine," p. 2.

${ }^{852}$ P. A. Clutterbuck, "Memorandum for the Prime Minister," June 28, 1946, External Affairs Records, LAC, RG 25, Vol. 5745, File: 47.B (5), Part 1. See attachment, p. 1.

${ }^{853}$ H. Freeman Mathews, "Memorandum of Conversation," April 27, 1946, in FRUS, 1946, Vol. 7, pp. 587-588. According to Matthews, Bevin was worried that "most of the immigrants were carefully selected for their military qualities by the Jewish Agency . . .." 
new recruits. ${ }^{854}$ Clutterbuck stated his government's intention to raid the offices of the Jewish Agency, arrest members of the Agency's executive who were implicated in the violence, and search for documents and weapons that incriminated the Agency, and, quite conceivably, American Zionists. ${ }^{855}$ If London failed to achieve its goals — uncovering the incriminating evidence against the Zionists - Anglo-American relations would be further endangered and violence in Palestine would expontially increase.

The British determination to end the Agency's role in fomenting violence and terror in Palestine was spelled out in the high commissioner's dispatch of July 4, 1946 to Norman Robertson, the under-secretary of state for external affairs. ${ }^{856}$ Clutterbuck informed Robertson that London was prepared to eliminate the private Jewish armies, which the British believed were determined to end London's authority in Palestine. Within days of Clutterbuck's memorandum, British forces had moved in and arrested 2,700 Jewish suspects, including Moshe Shertok, Bernard Joseph, and other members of the Jewish Agency Executive. ${ }^{857}$ They also seized large caches of contraband weapons and occupied the Agency's headquarters for more than three weeks. ${ }^{858}$

The ensuing Zionist response was not surprising to MacCallum. On July 22, 1946, a 15-member commando group from Irgun Zvai Leumi blew up a portion of Jerusalem's

\footnotetext{
854 James Byrnes, "Secretary of State to President Truman," May 9, 1946, in FRUS, 1946, Vol. 7, p. 602.

${ }^{855}$ Clutterbuck, "Memorandum for the Prime Minister," June 28, 1946, attachment, p. 1.

${ }^{856}$ P. A. Clutterbuck, "High Commissioner to Under-Secretary of State for External Affairs," July 4, 1946, External Affairs Records, LAC, RG 25, Vol. 3831, File: 8903-40, Part 1, pp. 1-3.

${ }^{857}$ Moshe Shertok was the secretary of the Jewish Agency's Political Department, and Bernard Joseph was legal adviser to the Political Department of the Jewish Agency.

${ }^{858}$ MacCallum, "Background of Discussions on Palestine,” p. 2.
} 
King David Hotel, housing the British Army's headquarters in Palestine. The explosion killed 95 British officers, as well as Jews and Arabs. Two days later, as MacCallum noted in "Background of Discussions on Palestine," a British White Paper was published alleging that evidence showed that the Jewish Agency's leaders had conspired and "authorized acts of terrorism and sabotage" against British strategic assets in Jerusalem. ${ }^{859}$ Whether MacCallum accepted Britain's evidence is unclear. What was more certain was that Palestine was now in a free-fall state and extremists dominated the Jewish Agency's agenda.

With respect to the other Arab states, MacCallum's study warned of wholesale Arab and Moslem uprisings throughout the Middle East. She also alerted the department to the ever-increasing "distorted and inflammatory anti-British propaganda" that was emanating from pro-Zionist and anti-Zionist Communist groups in the United States. ${ }^{860}$ It appeared that both Jewish groups now had a common enemy: Britain. In the case of the anti-Zionist Communists, MacCallum believed their anti-British propaganda was being directed from Moscow. The former intelligence officer with the State Department, J. C. Hurewitz, asserted that the U.S.S.R. was determined "to play a mischievous role in the Near East. ${ }^{" 861}$ In Soviet radio broadcasts into Arab states, Radio Moscow accused Britain and the United States of having imperialist designs throughout the Middle East, particularly in the Arab heartland. As for the Anglo-American inquiry, communist propagandists challenged the legitimacy and authority of London and Washington to

\footnotetext{
${ }^{859}$ Ibid.

${ }^{860}$ Ibid.

${ }^{861}$ Hurewitz, The Struggle for Palestine," p. 246.
} 
bypass the United Nations and the Arab states in resolving the Palestine issue. ${ }^{862}$ There was no doubt that Stalin wanted to discourage the establishment of a binational state in Palestine, where the British would be the trust authority. With Britain as the principal administrator, noted MacCallum, Russia feared that the British would set up military bases in Palestine and Transjordan that would thwart Stalin's ambitions in the region. These military facilities would enable Britain to establish a firewall that would deter Soviet encroachment on Turkey and Iran, explained MacCallum. ${ }^{863}$

On a strategic level, MacCallum's study revealed not only her apprehensions about the escalation of religious and nationalist tensions in the region, but about the Great Powers as they jockeyed for position. Great Power actions were motivated in large part by balance of power calculations, a view wholly supported by the State Department's Loy Henderson, who wrote in 1946 that he believed that four of the world's Great Powers — Britain, France, the United States, and the Soviet Union - were carrying out four different and opposing policies in the Middle East that might, if unchecked, "give birth to a third world war." 864

In an August 5th memorandum to St. Laurent, Wrong took up the question of Palestine's future status. He attached a copy of MacCallum's "Background Discussion" memorandum, and told the acting prime minister that the study included "a good deal of secret information," which provided a "useful summary of the stages whereby the present

\footnotetext{
${ }^{862}$ Ibid.

${ }^{863}$ Ibid.

${ }^{864}$ Loy Henderson, "Aspects of Thinking in the Department of State on Political and Economic Policies of the United States in the Near and Middle East," [n.d.] in FRUS, 1946, Vol. 6, pp. 1-6.
} 
difficulty and dangerous situation has risen." ${ }^{965}$ Wrong's support for MacCallum's analysis suggested that he saw her conclusions as reasonable and consistent with his own understanding of the facts. Overall, MacCallum findings suggested that the Canadian government should exercise extreme caution, carefully avoiding domestic and international pitfalls. She believed that this could be achieved by adapting the AngloAmerican Committee's recommendations to create a policy aimed at the creation of a United Nations Trusteeship recognizing and protecting the rights of both the Arab and Jewish peoples.

On August 13, 1946, MacCallum's draft response to the British aide memoire of July 26, 1946 was given to St. Laurent and Wrong. In addressing the British high commissioner's request for Canada to make a declaration setting forth the prime minister's steps for securing an international agreement on displaced persons, and announcing the numbers of refugees that Canada would accept, MacCallum insisted that, in "the opinion of the Canadian government," the prime minister had already declared his commitment to the problems of refugees and displaced persons. This was a matter of public record, she declared. ${ }^{866}$ Given Canada's previous statements, which provided ample proof of the government's intention to support the establishment of the International Refugee Organization (IRO), MacCallum had asserted that: "It is hardly necessary therefore for the Canadian Government to make now a further general statement on this statement." MacCallum's response further argued that "the suggestion

\footnotetext{
${ }^{865}$ Hume Wrong, "Memorandum for Mr. St. Laurent," August 5, 1946, in DCER, Vol. 12, 1946, p. 368.

${ }^{866}$ Elizabeth MacCallum, “Aide Mémoire,” August 13, 1946, External Affairs Records, LAC, RG 25, Vol. 5745, File: 47-B(s), Part 1, p. 1.
} 
that the Canadian government should at once declare its willingness to accept a specified number of displaced persons raised other issues." ${ }^{" 867}$ She noted that the King government believed that in the long run Canada could make a more effective contribution to the refugee crisis by modifying its existing immigration regulations rather than by an immediate public declaration of willingness to accept a substantial quota of refugees. ${ }^{868}$ On August 19th, Wrong handed Britain's high commissioner Canada's response to Clutterbuck's aide mémoire. ${ }^{869}$ No changes had been made to MacCallum's draft. Ten days later, Gerry Riddell, the acting secretary of state for external affairs, sent a copy of the memorandum to Canada's acting high commissioner in Great Britain. ${ }^{870}$

By the end of August 1946, with MacCallum's memoranda on Palestine and the Anglo-American rift before them, External Affairs officials began to explore in greater detail the American point of view with regard to Palestine. Thomas Stone, the Canadian Chargé d'Affaires in Washington, reiterated MacCallum's concerns about the nature of American decision making regarding Palestine. ${ }^{871}$ Stone reported that the views of the Zionists, the State Department's Middle East experts, White House advisers, and the president himself were at variance. In Stone's judgement, this had led to a muddled

\footnotetext{
${ }^{867}$ Ibid, p. 2.

${ }^{868}$ Ibid.

869 Hume Wrong, "Acting Under-Secretary of State for External Affairs to Minister of Mines and Resources," August 19, 1946, in DCER, 1946, Vol. 12, p. 369.

${ }^{870}$ R. G. Riddell, "[For] Acting Secretary of State for External Affairs to Acting High Commissioner in Great Britain," August 29, 1946, in DCER, 1946, Vol. 12, pp. 371-372.

871 Thomas A. Stone, "Memorandum," No. 1762, August 30, 1946, External Affairs Records, LAC, RG 25, Vol.3831, File: 8903-40, Part 1, p. 1.
} 
policy on Palestine. ${ }^{872}$ The chargé's assessment substantiated MacCallum's concerns about American thinking. In her August 30, 1946 memorandum, MacCallum went so far as to suggest that in America's long-term approach to Palestine, and the Middle East in general, American policy would be based, not on the strategic interests of the United States and considerations of world peace, but on the continued influence of the Zionists. $^{873}$

In an effort to hold an Anglo-Jewish-Arab conference to discuss the binational plan that the Anglo-American committee had recommended, Bevin invited both national communities in Palestine to London. The conference, known as the "Palestine Conference," was scheduled to begin on September 9, 1946, but both the Jewish and the Arab Palestinian communities turned down the invitations. ${ }^{874}$ Officially, the Arab Palestinian leadership declined because the Mufti of Jerusalem was refused a seat at the table because of his wartime ties to the Nazis, and the Zionists refused because of the arrest of activist Moshe Shertok and the self-imposed exile of David Ben-Gurion. ${ }^{875}$ In reality, the Jewish Agency refused to attend unless the British accepted as preconditions "that there must be a Jewish state with immediate control of immigration during the transition [and], they no longer claimed the whole of Palestine but were prepared to see it

\footnotetext{
872 Ibid.

${ }^{873}$ MacCallum, "United States Policy on Palestine," p. 1.

874 Elizabeth MacCallum, "Palestine Conference, September 9 to October 2, 1946," October 4, 1946, External Affairs Records, LAC, RG 25, Vol. 3831, File: 8903-40, Part 1, p. 1. See attachment: Government of Great Britain, "Account of Proceedings at Palestine Conference, London, September 9 to October 2, 1946, and of Discussion with Jews up to October 4, 1946."

${ }^{875}$ MacCallum, "Palestine Conference, September 9 to October 2, 1946," October 4, 1946, External Affairs Records, LAC, RG 25, Vol. 3831, File: 8903-40, Part 1, p. 1.
} 
partitioned and an Arab state established as well, both in treaty relations with the UK." ${ }^{\text {, }}$ The British were unwilling to accept the Zionist preconditions, knowing full well the Arabs would never agree to this initial framework. No compromise was found by the time the Palestine Conference began in September. Consequently, only three Arab states attended the meetings. While Bevin met with the representatives of the Arab states, British officials in Paris met with Jewish Agency officials to reach an agreement on London's binational plan. ${ }^{877}$

From the onset of the Conference, the British attempted to establish a scheme for provincial autonomy. As British officials expected, the Arab delegation refused to discuss any plan that would lead to a Jewish state. The Arabs believed that the establishment of a Jewish province would be, in MacCallum's words, a "bridgehead for Jewish political and economic penetration, first into the rest of Palestine and thereafter into Transjordan, Syria and the whole Arab World." ${ }^{878}$ Instead, the Arab delegation proposed a single plan for Palestine: the dissolution of the Palestine Mandate and the immediate establishment of an independent Arab Palestine, which would be instituted no later than December 31, 1946. ${ }^{879}$ The Arab scheme called for the establishment of a provisional government composed of seven Arab and three Jewish ministers of Palestinian nationality. Following the creation of the provisional government, the Arabs suggested that elections would be held for a Constituent Assembly, in which the Jews would have thirty percent

\footnotetext{
${ }^{876}$ Bullock, Ernest Bevin, p. 302.

${ }^{877}$ Ibid, p. 303.

${ }^{878}$ MacCallum, "Palestine Conference: Attachment," p. 1.

879 J. C. Hurewitz, The Struggle for Palestine, p. 263.
} 
representation. The Arab leaders demanded that future immigration of Jews be halted, and Jewish land purchase be restricted to the 1941 levels; the provisional government would control all schools, Jewish and Arab, with a view to preventing "subversive teaching"; and Arabic would be the official language of the country. ${ }^{880}$ On October 2 nd, British negotiators, knowing that the Arab proposal would never be accepted by the Zionists or the Americans, decided to suspend the Palestine Conference's deliberations until December $16,1946 .^{881}$

On October 3rd, Truman, against the advice of his acting secretary of state, W. L. Clayton, ${ }^{882}$ made a public statement about the Anglo-Arab negotiations. Truman's statement did not include an assessment of any pertinent facts or the Arab position; instead he insisted that the solution to the Palestine problem lay in the Jewish Agency's proposed partition plan. Furthermore, he urged "substantial immigration into Palestine cannot await a solution to the Palestine problem and that it should begin at once." 883

Truman's statement provoked an immediate outcry from Arab and British officials. The Arab leadership understood the statement to be a full-blown endorsement

\footnotetext{
${ }^{880}$ Ibid.

881 Viscount Addison, "Memorandum for Secretary of State for External Affairs," October 23, 1946, External Affairs Records, LAC, RG 25, Vol. 5745, File: 47.B (S), Part 1, p. 1. Addison told St. Laurent that they had "utilized the break to hold conversations with representatives of Jewish Agency with object of agreeing upon measures for reducing present tension in Palestine, if possible to a degree which might later make it possible for Jewish representatives to attend Conference."

${ }^{882}$ W. L. Clayton, "Memorandum by the Acting Secretary of State to President Truman," September 12, 1946, in FRUS, 1946, Vol. 7, p. 694. Clayton stated: "we do not believe that any statement at all should be issued by this government during the course of the present conversations. The situation in London is very delicate and without full knowledge of all the complicated elements in the situation, we might do more harm than good by intervening at this time. This is evidently the view of such observers on the spot as Secretary Byrnes and Ambassador Harriman."

883 "Statement by the President," October 4, 1946, External Affairs Records, LAC, RG 25, Vol. 3831, File: 8903-40, Part 1, p. 2.
} 
of partition and the immediate creation of a Jewish state. As historian Alan Bullock asserted: "For the first time Truman publicly committed the United States to support the Zionist plan for partition ...." ${ }^{884}$ Syrian and Iraqi officials immediately responded. They broke off their negotiations with the U. S. State Department regarding commercial air agreements. The Syrian government refused to grant transit rights to Aramco, ${ }^{885}$ and the Arabian-American Oil Company, whose projected pipeline was expected to run through Syria and end in Lebanon, deferred the project. In a charged letter to Truman, King Ibn Saud of Saudi Arabia accused the president of breaking earlier American promises to the Arabs. ${ }^{886}$ The consequences were clear. The Saudi King could cancel Aramco's oil concession. "That possibility greatly alarmed not only the interested [oil] companies, but also, of course, the U. S. State and Defense departments," wrote historian David Yergin. ${ }^{887}$

British reaction to Truman's statement, reported Thomas Stone in Washington, was predictably harsh. ${ }^{888}$ Attlee immediately wrote Truman and rebuked him for ignoring his government's plea to postpone his public statement on Palestine until after the Palestine Conference. ${ }^{889}$ Instead, insisted Attlee, the president refused "even a few hours grace" to allow the British government to find a solution to this difficult situation.

\footnotetext{
${ }^{884}$ Bullock, Ernest Bevin, p. 305.

${ }^{885}$ Daniel Yergin, The Prize: The Epic Quest for Oil, Money, and Power (New York: Simon \& Schuster, 1991), p. 410, 425. Aramco was the joint venture between Socal (Standard Oil of California) and Texaco.

886 Ibid.

${ }^{887}$ Ibid, p. 425.

888 Thomas Stone, "Memorandum to Under-Secretary of State for External Affairs," October 5, 1946, External Affairs Records, LAC, RG 25, Vol. 3831, File: 8903-40, Part 1, p. 1.

889 “British Prime Minister to President Truman," October 4, 1946, in FRUS, 1946, Vol. 7, p. 704.
} 
Angrily, Attlee told Truman that, "I am astonished that you did not wait to acquaint yourself with the reasons for suspension" of the Conference before commenting on the situation. "I shall await with interest to learn what were the imperative reasons which compelled this precipitancy." ${ }^{890}$ In response, Truman insisted that he felt "that the matter of the transfer of the displaced Jews was so urgent that it could not await the outcome of negotiations which promised to be of a protracted nature." ${ }^{891}$ Lord Inverchapel, the British ambassador to Washington, suggested it was now clear that "the President could no longer resist the pressure of groups within his party, particularly from New York, who have been "harassing and pestering him for so long." " 892

On October 4, 1946, summarizing a confidential British report on the Palestine Conference, MacCallum reported that London's assessment gave little hope that the Arabs and Jews would accept a federated Palestine, in which the Jews were given an autonomous province. ${ }^{893}$ The Arabs' chief argument, reiterated MacCallum, was that:

setting economic absorptive capacity as the only limitation on immigration into the Jewish province would enable the Zionists to establish there a dense population on the basis of an industrial and commercial economy. When they have created conditions warranting a demand for more ... living space they would encroach progressively on Syria, Transjordan, and the whole Arab World. ${ }^{894}$

This assessment echoed an earlier cautionary message by Azzam Pasha, head of the Arab League, who rejected the binational scheme on the grounds that: "Immigration into

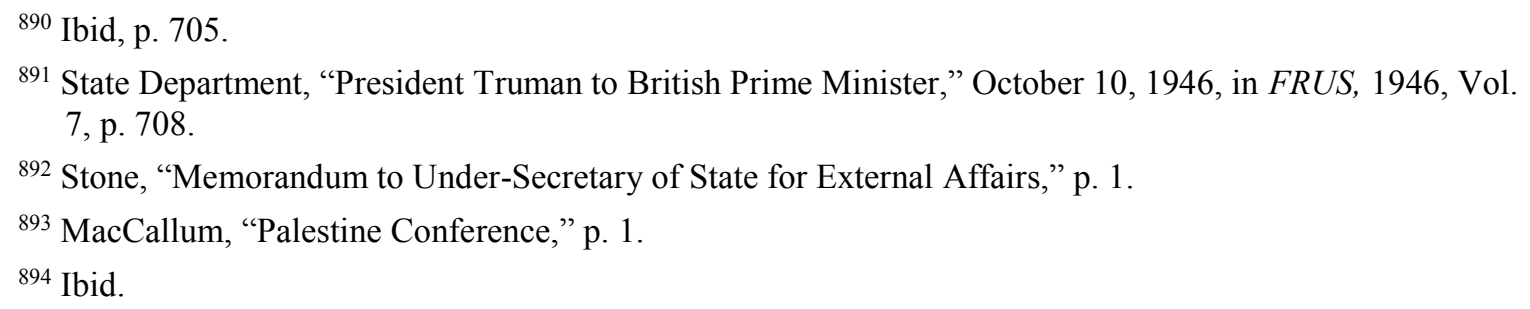


Jewish provinces as proposed could lead only to over-population there and further Zionist insistence on territorial aggrandizement." 895

For the remainder of 1946, the Anglo-American relations continued to be tense, and questions of Palestine's political status were left unanswered. Truman's policy was rigidly fixed on the immigration of 100,000 Jewish refugees into Palestine, and Attlee was unwavering in his refusal to implement the immigration recommendation. In the meantime, MacCallum continued to monitor and document Zionist efforts to build a bridgehead in Canada.

Throughout November and December 1946, MacCallum met on numerous occasions with Samuel Zacks, president of the Zionist Organization of Canada (ZOC), to discuss the Canadian government's position on Palestine. During her November 15th meeting with Zacks, he expressed the view that Canada should use its influence with Great Britain to convince it to accept Truman's proposal of October 4, 1946. MacCallum replied, "Canada could be counted upon to support any plan for Palestine on which the Governments of the United Kingdom and United States could agree." In response to MacCallum's question about conflicting ideas within the Zionist leadership, Zacks shared ZOC's concern about the growing differences among various American Zionist factions over the Biltmore Programme of 1942, which "committed Zionists to work for the establishment of a Jewish state in the whole of Palestine." Until the dust had settled on

${ }^{895}$ Cecil B. Lyon, “U. S. Chargé in Egypt to the Secretary of State," August 2, 1946, in FRUS, 1946, Vol. 7, p. 676. 
the question of partition, declared MacCallum, increasing Arab-Jewish instability would be the dominant feature of the Palestine impasse. ${ }^{896}$

In a note to Lester B. Pearson, the under-secretary of state for external affairs, following her November 15th meeting with Zacks, MacCallum voiced her concern about the dangers associated with the actions of extremist groups in the American Zionist movement, and to a lesser degree, among the Arab leaders. ${ }^{897}$ In particular, she cautioned Pearson about Rabbi Abba Hillel Silver, who had assumed the presidency of Zionist Organization of America in 1943, and his followers, who posed a significant threat to any "reasonable settlement" in Palestine. ${ }^{898}$ MacCallum saw growing signs that extremist elements in the Arab and Jewish communities were seizing control of their national communities leadership. Weizmann had been replaced by David Ben-Gurion and the Arab high commissioner was now being led by Haj Mohammed Effendi Amin elHusseini, the grand mufti of Jerusalem.

\section{Conclusion}

For MacCallum, 1946 ended in a precarious stalemate. Truman and Attlee appeared steadfastly divided over the fate of Palestine and Europe's Jewish refugees and displaced persons. With the sudden death of Roosevelt, the electoral defeat of Churchill, and a rapidly deteriorating refugee and displaced persons crisis in Europe, MacCallum witnessed a struggle among the United Kingdom, the United States, the Arab World, and

\footnotetext{
${ }^{896}$ MacCallum, "Palestine Conference," p. 1.

${ }^{897}$ Elizabeth MacCallum, "Note for Mr. Pearson," November 15, 1946, External Affairs Records, LAC, RG 25, Vol. 3831, File: 8903-40, Part 2, p. 1.

${ }^{898}$ Bercuson, Canada and the Birth of Israel, p. 40. According to Bercuson, MacCallum "believed Silver and Ben-Gurion would go to any lengths, possibly including war, to secure their aims ....."
} 
International Zionism over the fate of the Palestine Mandate and Jewish statehood. Extremist voices in the Jewish and Arab camps seemed to dominate the discourse. Acts of terrorism, attempts to smuggle Jewish refugees into Palestine, and harsh British countermeasures created an environment of conflict and escalation.

MacCallum noted that the plight of Jewish refugees and displaced persons threatened to open up greater divisions in Canada over immigration policy, and embolden the pro-Zionist forces in Canada to apply ever greater pressure on the King government to support their aims. The most pressing concern for Canadian officials, however, was the deteriorating Anglo-American relationship, the bedrock of Canada's postwar security strategy. Its breakdown would have a significant impact on the work of the Western alliance in containing Soviet expansionism, and in maintaining a fragile postwar peace. MacCallum despaired that the common approach, which the Americans, British, and Canadians had previously taken regarding the establishment of a Jewish state in Palestine, had been laid waste by conflicting Anglo-American strategies. She feared, too, that the Arab and Moslem Worlds would oppose all Western efforts to establish a Jewish state in the heart of Arab lands. They would see it as a betrayal to Arabs, violating their right of self-determination. It was a trip-wire to war.

Through a series of cautionary memoranda in late 1945 and 1946, MacCallum warned about the dangers to the Canadian government posed by the Palestine impasse and the Anglo-American schism. She revealed the growing likelihood that a major conflict in the Middle East would force the United States and Great Britain to take opposing sides, that the Arab World would be forever alienated, and that the Soviet 
Union would feast on Anglo-American divisions. Her efforts were recognized by Wrong and other senior External Affairs officials. MacCallum had proved the value of having a regional specialist on staff. She had become an effective and reliable source of information for a department inadequately prepared to deal with the eddies of Middle Eastern politics. She offered valuable historical and strategic insight into AngloAmerican ambitions for the region and into the widening Arab-Jewish conflict, which would preoccupy the department in 1947. 


\section{Chapter 6 Pearson's Triumph, MacCallum's Tragedy: Palestine 1947}

By 1947, Elizabeth MacCallum had arrived. In the span of five short years, MacCallum had demonstrated to senior officials of the Department of External Affairs (DEA) her abilities and acumen in international affairs. ${ }^{899}$ To Norman Robertson, the Canadian high commissioner to the United Kingdom, Hume Wrong, the Canadian ambassador to the United States, and Escott Reid, the assistant under-secretary of state for external affairs, she had disproven the notion that women were ill suited for policy work, and that international affairs were the exclusive domain of men. She had also demonstrated the value of having experts outside of External Affairs' traditional field of vision. MacCallum showed that the department's "generalist idea" — a diplomat of allaround ability — was a policy that ignored the postwar realities. ${ }^{900}$ External Affairs needed to possess a broader understanding of the world, and move its foreign policy from a Great Power-centric design to one that included great and small powers alike. This meant that the department must seek out individuals who possessed a specialized knowledge and understanding of areas previously overlooked — individuals like MacCallum.

899 On April 1, 1947, MacCallum was promoted to the rank of Head Clerk. Shortly thereafter, she was appointed as the department's principal drafting officer for Middle East affairs. See Charles Bland, "C.S.C Letter of Reclassification," March 28, 1947, Civil Service Commission (CSC) Papers, Library and Archives Canada (LAC), RG 32, Vol. 451, File: Elizabeth Pauline MacCallum.

${ }^{900}$ For a more detailed explanation of the generalist principle, see: James Eayrs, The Art of the Possible: Government and Foreign Policy in Canada (Toronto: University of Toronto Press, 1961), pp. 53-54; Marcel Cadieux, The Canadian Diplomat, [translated by Archibald Day] (Toronto: University of Toronto Press, 1962), p. 59. 
Following the British government's 1946 decision to allow women to enter the diplomatic corps, the DEA opened up its foreign service officers' examinations to women. ${ }^{901}$ On October 1, 1947, after successfully conquering the department's examinations and interview process, MacCallum was among the first female candidates awarded the rank of Foreign Service Officer (FSO). ${ }^{902}$ She was soon thereafter appointed "Officer Responsible for Middle East Affairs." 903 She became the face of women in the Canadian foreign service. When questioned or criticized about the lack of women in diplomatic positions, the department referred to MacCallum as proof of their commitment to gender equality. ${ }^{904}$

\footnotetext{
901 Ernest Bevin, "Memorandum by Secretary of State for Foreign Affairs," February 20, 1946, The National Archives (TNA), Cabinet Papers, Vol. 46, No. 70, p. 1. Also see: "Women to be Diplomats: British Government Approves Inclusion in Service," New York Times, March 21, 1946, p. 2. The 1946 Gowers Commission report recommended that women should be made eligible for admission to Britain's diplomatic service. Consequently, Ernest Bevin, the British foreign minister, announced on March 20, 1946 that the foreign service "was now open to women." On February 11, 1947, Lester Pearson, the Canadian under-secretary of state for external affairs, announced the opening up of the foreign service officer's examinations to women. For more detail on this announcement, see: T.W.L MacDermot, "Memorandum for Lester Pearson," February 6, 1947, External Affairs Records, LAC, RG 25, Vol. 2489, File: 156-F, Recruitment of Women as Foreign Service Officers in External Affairs.

${ }^{902}$ Civil Service Commission of Canada, "C.S.C Letter of Reclassification," March 28, 1947, Civil Service Commission Papers, LAC, RG 32, Vol. 451, File: Elizabeth Pauline MacCallum. Also see: S. D. Helmsley, "Memorandum to the Secretary of Civil Service Commission," October 10, 1947, LAC, Civil Service Commission Papers, RG 32, Vol. 451, File: Elizabeth Pauline MacCallum. She was given the rank of FSO, Grade 2 in 1947 and by 1954, MacCallum had achieved the rank of Foreign Service Officer (FSO), Grade 5. For further detail, see: "Certificate of Promotion," July 1, 1954, Civil Service Commission Papers, LAC, RG 32, Vol. 451, File: Elizabeth Pauline MacCallum.

903 Allison T. Hardy, "Women: Always Diplomatic and More Recently Diplomats," International Perspectives (July-August, 1976), p. 28.

904 Escott Reid, "Letter to Irene Campbell, Executive Secretary of the Canadian Women's Clubs," November 2, 1948, External Affairs Records, LAC, RG 25, Vol. 2489, File: 156-F, Recruitment of Women as Foreign Service Officers in External Affairs; Jules Léger, "Memorandum for the High Commissioner for Australia," April 4, 1949, External Affairs Records, LAC, RG 25, Vol. 2489, File: 156-F, Recruitment of Women as Foreign Service Officers in External Affairs.
} 


\section{Moving Palestine to New York}

As the second session of the United Nations General Assembly (UNGA) approached, officials in the East Block had much to consider. What was the best way to respond to the mounting Great Powers" "ideological brawl?"905 How would the differences between the Americans, British, and Soviets shape the discussions on disarmament and arms control, the elections to the Trusteeship Council, the fate of displaced persons in Europe, and the growing international tension concerning the Palestine question?

MacCallum focused all of her attention on preparing for the upcoming session of the Assembly. Her responsibilities had been significantly enlarged since the San Francisco Conference and the first session of the General Assembly. She was now responsible for assessing and making recommendations to Canada's UN delegation regarding the Indian-Pakistani civil tensions, India's dispute with South Africa, AngloEgyptian tensions, proposed Trusteeships agreements, and the ongoing crisis in Palestine. ${ }^{906}$ The last of these went to the heart of MacCallum's interests and concerns. On the morning of April 2, 1947, Victor Hoo, the acting secretary-general of the United Nations, notified the Canadian Secretary of State for External Affairs Louis St. Laurent that the British government had approached Trygve Lie, the secretary-general of the United Nations, formally requesting that the Palestine Mandate be placed on the agenda of the upcoming session of the Assembly. The government of Great Britain, added Hoo,

\footnotetext{
905 Maurice Western, "Canada's Role in the Second Assembly," International Journal, Vol. 3, No. 2 (Spring, 1948), p. 120.

906 C. M. Drury, "Key Plan for the Second Session of the General Assembly," September 16, 1947, External Affairs Records, LAC, RG 25, Vol. 1054, File: 6, pp. 1-4.
} 
had further requested that a special session of the General Assembly be convened to study the Palestine impasse and report thereon. ${ }^{907}$ The British foreign secretary, Ernest Bevin, had fulfilled his threat to the Jewish Agency: "If the London talks . . . could produce no agreed solution he thought the British Government would have to lay the problem without recommendation before the U.N."908 Some scholars, wrote Israel historian Benny Morris, "have suggested that by threatening the sides with the unknown and the unpredictable, Britain may have been aiming to force them to accept its latest proposals, or to accede in a prolongation of the Mandate." 909

According to the recollection of Lester B. Pearson, the under-secretary for external affairs, the British request threw everyone in the East Block into a tailspin. ${ }^{910}$ Was the department's reaction one of surprise or frustration? It is highly doubtful that Canada was surprised by London's decision, since Britain had publicly announced its decision, as early as February 15, 1947, to "shed another of her problem children and hand Palestine's woes over to the United Nations" following the abrupt termination of the

${ }^{907}$ United Nations Information Organization, Weekly Bulletin, II, pp. 423-424. Also see: UN Doc. A/286, April 3, 1947.

908 "Palestine: Memorandum by the Secretary of State for the Foreign Affairs and the Secretary of State for the Colonies," TNA, Cabinet Papers, (47) 59, February 13, 1947, p. 1. Also see: Waldemar Gallman, "Chargé in the United Kingdom to the Secretary of State," February 4, 1947, Foreign Relations of the United States (FRUS), 1947, The Near East and Africa, Vol. V (Washington D.C.: Government Printing Office, 1971), p. 1025; Viscount Addison, "Memorandum for the Secretary of State for External Affairs," February 11, 1947, External Affairs Records, LAC, RG 25, Vol. 5745, File: 47-B(S). In his memorandum to St. Laurent, Addison discussed the resumption of the Palestine Conference in London, and Britain's revision of the White Paper of 1939 plan for Palestine.

${ }^{909}$ Benny Morris, Righteous Victims: A History of the Zionist-Arab Conflict, 1881-1999 (New York: Alfred A. Knopf, 1999), p. 181.

910 John A. Munro and Alex I. Inglis (eds.), Mike: The Memoirs of the Right Honorable Lester B. Pearson, Vol. 2, 1948-1957 (Toronto: University of Toronto Press, 1973), p. 213. 
second London Conference. ${ }^{911}$ Throughout the remainder of February and March of 1947, Ottawa had discussed the issue with Robertson and Wrong and with British officials in the Colonial Office. ${ }^{912}$ Frustration and anger, however, there certainly was. In a 1979 interview with journalist Peter Stursberg, George Ignatieff admitted that many of the department's officials, and Pearson in particular, were angry at the British for the situation in which Canada had been placed.

Why were we picking up the pieces and trying to put the Humpty Dumpty of the collapsing British Empire back together again? . . . One must remember that it wasn't just Israel and Palestine. We [had] gone through the same thing over Kashmir with India and Pakistan, and the blood shed on that was just as dumb. And then, to have Palestine dumped on us and all at the same time! $!^{913}$

More importantly, Canada had now been placed into the direct path of two colliding forces: the United States and Great Britain. According to John Munro and Alex Inglis, Pearson's memoir writers, the under-secretary's expressed the department's and the prime minister's displeasure at being drawn into the British quagmire. Pearson believed that:

Before World War II, there had been no Canadian policy on Palestine or on the Arab-Jewish difficulties under the British Mandate. Mr. King had merely stated once or twice that he supported, in theory, the British pledge

\footnotetext{
911 “Britain May Call Special UN Meet Over Palestine," The Globe And Mail, February 15, 1947, p. 2. Also see: Benny Morris, Righteous Victims, p.180.

912 See: R. L. Rogers, "Palestine," February 12, 1947, External Affairs Records, LAC, RG 25, Vol. 3831, File: 8903-40, Part 2; Elizabeth MacCallum, "Comments on British Policy in Palestine," February 26, 1947, External Affairs Records, LAC, RG 25, Vol. 3831, File: 8903-40, Part 2; Hume Wrong, "Memorandum for the Secretary of State for External Affairs," February 26, 1947, LAC, External Affairs Records, RG 25, Vol. 3831, File: 8903-40, Part 2; Norman Robertson, "Memorandum for the Secretary of State for External Affairs," February 27, 1947, King Papers, LAC, MG 26, J1, Vol. 429; Viscount Addison, "Memorandum for the Secretary of State for External Affairs," March 8, 1947, External Affairs Records, LAC, RG 25, Vol. 5747, File: 47-B(S), Part 1.

913 Peter Stursberg (ed.), Lester Pearson and the American Dream (Toronto: Doubleday Canada Ltd., 1980), p. 68.
} 
in the 1917 Balfour declaration to establish a national home for the Jews. But in his view there was no need to do more about a purely British problem, even when this problem was made tragically more serious by Nazi persecution. . . . Now the British government decided that it could no longer discharge its responsibilities in Palestine and at a special session of the General Assembly called on 28 April 1947 to deal with the Palestine question, Canada became involved. ${ }^{914}$

With the British announcement, the Palestine question instantly moved from being a British problem to an issue of international concern, a matter that neither Canada nor the United Nations could ignore or avoid. ${ }^{915}$ The implications were obvious to Ottawa: if the United Nations was unable to resolve the Palestine question quickly, decisively, and peacefully, the whole region could be thrown into bloodshed, chaos, and uncertainty. ${ }^{916}$ Furthermore, if the United Nations was unable to settle the issue, the organization's legitimacy and its value as an instrument of Canadian foreign policy could be permanently damaged. For many in External Affairs, Palestine asked the question: was the United Nations up to a serious task?

MacCallum was dubious about the United Nations' capacity to resolve the ArabJewish dispute. In "Comments on British Policy in Palestine," she warned the department that there was a real danger that the world body would be unable to find a compromise, given the intractable positions that both the Arabs and Zionists had taken. ${ }^{917}$ She knew very well that the Arabs would not accept anything short of the total independence of an

\footnotetext{
${ }^{914}$ Munro and Inglis, Mike, Vol. 2, p. 212.

915 Ibid.

916 Ibid, p. 213.

917 MacCallum, "Comments on British Policy in Palestine," pp. 1-2. Also see: Elizabeth MacCallum, "United Kingdom Policy in Palestine," February 25, 1947, External Affairs Records, LAC, RG 25, Vol. 3831, File: 8903-40, Part 2.
} 
Arab Palestine. Dr. Jamal Husseini, chief spokesperson for the Arab Palestinian delegation to the London Conference, repeated this demand when he stated that the "Palestine Arabs 'will not consider any UN decision as arbitrary — we will only be bound by our rights and continue fighting until we get them.""918 The Zionists made it equally clear that they would accept nothing less than the establishment of a sovereign Jewish state. In MacCallum's mind, Arab and Jewish intractability would lead to only one possible outcome: the United Nations would be compelled to use force to impose a solution on Palestine. This would either result in the hostility of millions of Moslems or the further embitterment of the world's remaining Jewry. It would also require outsiders to administer the forced arrangement, a duty the Canadian prime minister refused to undertake. ${ }^{919}$ Hume Wrong concurred with MacCallum's assessment of the situation. In a February 26, 1947 memorandum to St. Laurent, he stated:

Not only did the United Nations offer no prospect of a speedy solution which would assist in dealing with the refugees of Europe, but also the United Nations possesses no magic wand which will harmonize the irreconcilable demands of the Arabs for a unitary state controlled by the (Arab) majority and of the Jews for partition with a viable Jewish state. . . .Over one particular point all opinion agrees, the Palestine question is the most complex yet submitted to the United Nations. . . ${ }^{920}$

For Pearson, a United Nations failure would not only raise more questions about the tying of Canadian interests to an organization that seemed incapable of exercising its primary responsibility of maintaining peace, but also undoubtedly lead Canadian

\footnotetext{
918 “Britain May Call Special UN Meet Over Palestine,” p. 2.

${ }^{919}$ King Diary, December 18, 1947, p. 4. King noted that: "we must not stay in it [the United Nations] if it means we are risking being drawn in wars; put into a position where we might become ostensibly responsible for a pretext for war."

${ }^{920}$ Wrong, "Memorandum for Secretary of State for External Affairs," pp. 3-4.
} 
Opposition parties and the press to question his management of the Canadian delegation's efforts at the United Nations. With so many people watching the deliberations unfold at the United Nations, he was not prepared to sit on the sidelines. In the weeks following Palestine's referral to the United Nations, there was intense activity in Ottawa preparing for the upcoming session of the Assembly. There were lively discussions among the department's senior officers and their American, British, and United Nations counterparts regarding the procedures governing the special session. Since the Charter had no mechanisms to deal with a special or emergency session, ${ }^{921}$ a provisional set of procedures were worked out for the General Assembly to follow.

On April 12, 1947, St. Laurent, with the reluctant approval of the prime minister, gave the United Nations Canada's formal support in convening a special session of the General Assembly to deal with the Palestine question. ${ }^{922}$ Two days later, St. Laurent received approval from cabinet to form a small delegation, led by Pearson, ${ }^{923}$ to represent Canada at the special session. R. G. Riddell, head of External Affairs' First Political Division, was chosen to serve as the delegation's alternative representative. George

${ }^{921}$ Elizabeth MacCallum, "Secretary of State for External Affairs to the General-Secretary of the United Nations Organization," [Not Sent], April 12, 1947, External Affairs Records, LAC, RG 25, Vol. 3831, File: 8903-40, Part 2, p. 1.

${ }^{922}$ Louis St. Laurent, "Memorandum for the Secretary-General of the United Nations," April 12, 1947, in Documents on Canadian External Relations (DCER), Vol. 13, 1947 (Ottawa: Government of Canada, 1993), p. 914.

${ }^{923}$ Eliezer Tauber, Personal Policy Making: Canada's Role in the Adoption of the Palestine Partition Resolution (Westport, Conn.: Greenwood Press, 2002), p. 2. Tauber claimed that the prime minister "probably felt it would be better for Canada to be represented by a mere civil servant than by St. Laurent himself." 
Ignatieff and Elizabeth MacCallum would act as special advisors to Canada's delegation. ${ }^{924}$

Palestine held a special place in Pearson's heart and childhood memories. In Mike, Pearson admitted that he "became emotionally involved in a very special way because we were dealing with the Holy Land - the land of my Sunday school lessons." Consequently, he confessed that "it made the dispute much more real in my mind. . ."925 These feelings were undoubtedly heightened by Pearson's sympathy for the plight of Jewish refugees. The Canadian government, and indeed External Affairs, had done almost nothing during the Second World War to meet the suffering of the European Jews. $^{926}$

Like Pearson, Gerry Riddell was strongly influenced by his upbringing. His father, Reverend John Henry Riddell, the principal of Wesley College in Manitoba, passed on to his son a "profound sense of public service and Christian responsibility." Riddell's faith had directed much of his personal and professional life. At the University of Toronto, he had taught the history of the church. As a member of the department, he voiced the view that the "values of the Christian civilization were key determinants of Canada's

\footnotetext{
${ }^{924}$ R. G. Riddell, "Memorandum for George Ignatieff," April 15, 1947, External Affairs Records, LAC, RG 25, Vol. 3694, File: 5475-CD-40C, Part 1; Louis St. Laurent, "Memorandum for the Secretary-General of the United Nations," April 16, 1947, External Affairs Records, LAC, RG 25, Vol. 5745, File: 47$\mathrm{B}(\mathrm{S})$, Part 2.

${ }^{925}$ Munro and Inglis, Mike, p. 213.

926 Irving Abella and Harold Troper, None is Too Many: Canada and the Jews of Europe, 1933-1948 (Toronto: Lester \& Orpen Dennys Ltd., 1982), pp. 173-177.
} 
international outlook." 927 Riddell's experiences in the building of the International Refugee Organization familiarized him with many of the horrors of the Holocaust and the plight of the Jewish refugees in postwar Europe. ${ }^{928}$ This would profoundly mark his approach to the Palestine problem. Ignatieff was also moved by the plight of the Jews and the Holocaust. In The Making of a Peacemonger, he recalled that:

Not that I was unsympathetic to the claims of the Palestinian Arabs or unaware of the contradictory promises that had been made to them and to the Jews before and during the war. . . But in 1947 the humanitarian aspect of the problem - the horrors of the holocaust and the plight of the Jewish refugees who had nowhere else to go — seemed to me to outweigh all other considerations. $^{929}$

As for MacCallum, she had watched, written, and spoke on the Arab-Jewish conflict. She understood that both Arabs and Jews had suffered under the yoke of foreign oppression. Like Pearson and Riddell, she had been raised in a Christian home where a sympathy with the Jewish culture and history were an integral part of her Christian experience. In writing the weekly wartime briefings for the prime minister, MacCallum was privy to many of the details of the Holocaust and Jewish suffering. However, she differed from her colleagues in that her experiences and memories also included knowledge of the injustices done to the Arab peoples.

In preparation for the United Nations special session, MacCallum drafted a pair of memoranda examining some of the key problems that the Canadian delegation would

\footnotetext{
${ }^{927}$ Hector Mackenzie, “Gerry Riddell: A Golden Age Idealist?,” in Greg Donaghy and Kim Richard Nossal (eds.), Architects and Innovators: Building the Department of Foreign Affairs and International Trade, 1909-2009 (Montreal \& Kingston: McGill-Queen's University Press, 2009), p. 170, 172, 175.

${ }^{928}$ Hillmer, "Canadian Policy on Partition of Palestine," p. 20.

${ }^{929}$ George Ignatieff, The Making of a Peacemonger: The Memoirs of George Ignatieff (Toronto: University of Toronto Press, 1985), pp. 102-103.
} 
encounter during the special session's deliberations. In her first memorandum, "Palestine," MacCallum summarized the growing dangers that the situation posed to the international community. In her judgment, the dispute, which had grown and festered for more than 25 years, was firmly rooted in the Palestine Mandate's inherent incongruities. "The Palestine Mandate promised the Jews a national home, providing for a virtual invasion of the country by thousands of immigrants," yet at the same time it promised the Arabs "that this was not to disturb the people in possession. These promises are mutually contradictory." 930

For MacCallum, the peaceful resolution of the Arab-Jewish dispute would not be found in extending or modifying the existing Mandate, but in establishing a Palestinian state. She wholly rejected the idea that Palestine could be administered by the British under a modified Mandate or a new Trusteeship, especially under the present conditions. ${ }^{931}$ For both the Arabs and the Jews, the presence of Britain as an administrator was no longer acceptable. For that reason, speculated MacCallum, there were four possible options that the United Nations could consider: should Palestine be a Jewish, Arab, or a binational state, or should it be placed under a United Nations-administered Trusteeship?

MacCallum's memorandum further cautioned that time was critical. If the special session could not find a speedy solution, a "much wider trouble [would] develop -

\footnotetext{
${ }^{930}$ Elizabeth MacCallum, "Palestine,” April 16, 1947, External Affairs Records, LAC, RG 25, Vol. 3831, File: 8903-40, Part 1, p. 1. ${ }^{931}$ Ibid.
} 
perhaps even another war. .. ." 932 Her memorandum was particularly blunt in warning the department about the dangers of imposing a settlement by force. Such a settlement would not end the dispute, claimed MacCallum; in all likelihood it would unleash a conflict far greater than the existing one. She believed the only solution was for Canada to seek a negotiated settlement to the impasse. After the failure of the second London conference, she was convinced that both the Arabs and Jews had shifted their positions sufficiently to facilitate an agreement. If a negotiated solution was not possible, advised MacCallum, then the only solution left to the United Nations was to impose a Trusteeship — an option in which she had little faith. ${ }^{933}$

On April 17, 1947, just days after her promotion to Head Clerk, MacCallum presented the department with a second memorandum, entitled: "Formal Decisions of Various Governments in Relation to the Balfour Declaration." "934 The memorandum was possibly a response to a memorandum sent to St. Laurent by Samuel Zacks, the president of the Zionist Organization of Canada. Zacks' memorandum claimed that Canada was morally and legally bound to support the establishment of the Jewish National Home. ${ }^{935}$ Echoing the assertions made in 1943 by the prominent Ottawa Zionist A. J. Freiman, Zacks claimed that the "Palestine Mandate, ratified by all members of the League of Nations and by the United States,' gave recognition to the historic rights of the Jewish

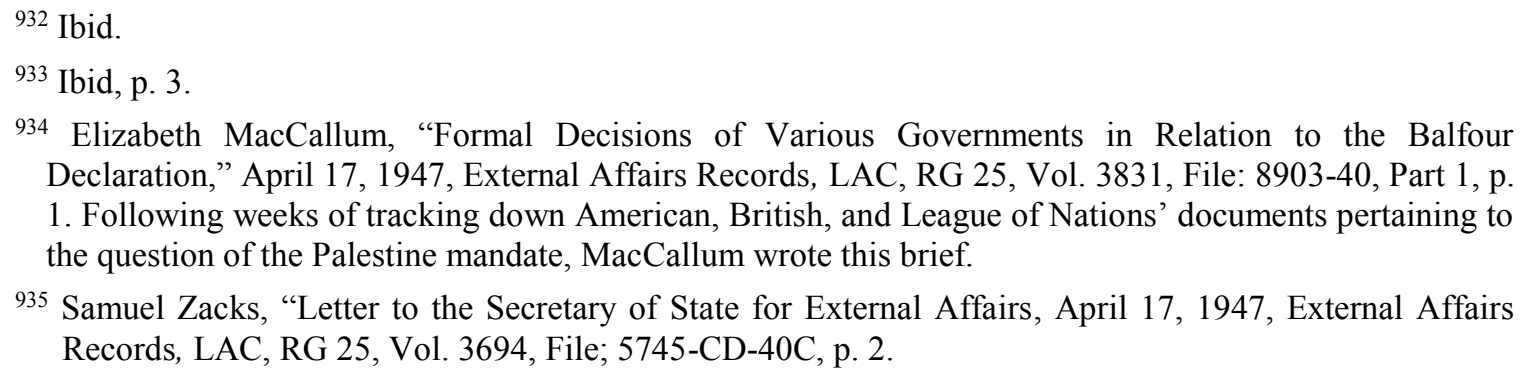
Declaration," April 17, 1947, External Affairs Records, LAC, RG 25, Vol. 3831, File: 8903-40, Part 1, p. 1. Following weeks of tracking down American, British, and League of Nations' documents pertaining to the question of the Palestine mandate, MacCallum wrote this brief.

${ }^{935}$ Samuel Zacks, "Letter to the Secretary of State for External Affairs, April 17, 1947, External Affairs Records, LAC, RG 25, Vol. 3694, File; 5745-CD-40C, p. 2. 
people to Palestine," and that it was "recognized and accepted by all the Allied Powers and indeed by 52 nations. ..." ${ }^{936}$ MacCallum saw this assertion as without merit or fact. Repeating the numerous objections that she had stated over the last five years, she rejected the Zionist view that the League of Nations Council or its Assembly were empowered to confirm Mandates. She also argued that Canada was neither morally or legally obligated to the Balfour Declaration or the British Mandate. The historical record in her view presented a very different narrative of Canada's pledges and international obligations. ${ }^{937}$

On April 23, 1947, five days before the special session was to commence, Ignatieff flew to Ottawa from New York to confer with MacCallum and Riddell. In a late afternoon meeting in the East Block, Ignatieff briefed his colleagues on the official and rumoured developments emanating from Lake Success, New York, the temporary United Nations home for the upcoming session. According to MacCallum's account of the meeting, Ignatieff told them that Washington was pushing hard for Canada's membership on the Assembly's investigative committee, which would be sent to Palestine to examine the situation and report back to the General Assembly. ${ }^{938}$ MacCallum cautioned that Canada should not take a seat on such a committee. "No Member, except the Arab States,

\footnotetext{
936 Ibid.

937 Elizabeth MacCallum, "Memorandum for Mr. Glazebrook: Re: Mr. Freiman's Letter of December 3, 1943," December 17, 1943, External Affairs Records, LAC, RG 25, Vol. 1839, Part 2.

938 The Preparatory Committee, or commonly known as the United Nations Special Committee on Palestine (UNSCOP), would be tasked with investigating the situation on the ground, and reporting back to the special assembly on Palestine.
} 
is likely to desire representation on the . . Committee."939 Yet Riddell, Ignatieff, and MacCallum believed that, if Canada was pressed to serve on the committee, it should be prepared to appoint a qualified representative. ${ }^{940}$ There was, added Ignatieff, a strong likelihood that the Americans would nominate Pearson as chairperson of the general committee, or at least to membership of one of the main committees overseeing the Palestine discussion.

The following day, at the request of St. Laurent and Pearson, MacCallum and Riddell were called to the minister's office to discuss the delegation's strategy for the upcoming session. ${ }^{941}$ The minister, who was noticeably pensive, allowed Pearson to direct much of the discussion. The meeting opened with MacCallum and Riddell elaborating on their assessments of the upcoming session and the pitfalls that Canada needed to avoid. After they had finished, Pearson voiced his own concerns about the special session. He warned that there was a real danger that the session could spin out of control and degenerate into a long drawn-out debate on the Balfour Declaration, the Palestine Mandate agreement, and the Arab and Jewish claims. Canada must avoid being drawn into any debate on Palestine's status prior to the investigative work necessary to finding a solution, advised Pearson.

MacCallum shared his suspicions that the Arabs would try to call for an early vote on the immediate independence of Palestine as a unitary Arab State. This would lead, in

939 Elizabeth MacCallum, "Memorandum: Likely Procedures at Special Session of the United Nations Assembly," April 24, 1947, External Affairs Records, LAC, RG 25, Vol. 6210, p. 1.

940 David Bercuson, Canada and the Birth of Israel: A Study in Canadian Foreign Policy (Toronto: University of Toronto Press, 1985), p. 64.

${ }^{941}$ Elizabeth MacCallum, “Memorandum for File,” April 25, 1947, in DCER, Vol. 13, p. 918. 
her opinion, to a protracted and divisive debate that would further illustrate the growing fractures between American and British policymakers, and, more importantly to MacCallum, expose the pro-Zionist sympathies among the Western powers. Concurring with MacCallum's assessment of the Arabs, Pearson stated that there should no Canadian comment on the Mandate until the investigating committee submitted its full report to the General Assembly. The first undertaking should be a procedural one: the establishment of an investigative commission. Pearson then said that Canada needed to avoid any direct participation in the committee's work, if at all possible. St. Laurent agreed with Pearson's view: "while they did not wish to shirk responsibility for things which had to be done, it would nevertheless be more convenient for us if we were left off the Special Committee."942 The meeting concluded with St. Laurent conveying the prime minister's and Cabinet's instructions that, for the time being, Pearson and his delegation were to observe and report, taking a low-key approach to the Assembly's deliberations. Most importantly, they were to avoid all commitments regarding Palestine's fate. ${ }^{943}$

\section{An UNSCOP in View}

On the morning of April 28, 1947, the United Nation's special session began its investigation into the Palestine question at its temporary quarters in a former skating rink in Flushing Meadows, New York. ${ }^{944}$ Public interest was intense; more than twenty

\footnotetext{
${ }^{942}$ Louis St. Laurent, "Secretary of State for External Affairs to the Consul General in New York," May 7, 1947, in DCER, Vol. 13, p. 923.

943 MacCallum, "Memorandum for File," p. 918.

944 David Bercuson, Canada and the Birth of Israel, p. 67.
} 
thousand people had requested tickets to the proceedings. ${ }^{945}$ Journalists from all over the world descended on Flushing Meadows to cover the historic event, and numerous radio stations planned to broadcast the proceedings. MacCallum worried that the session was liable to turn into a public spectacle. The circus-like atmosphere, she said, could "impede the business of the special session because speakers would inevitably address themselves to the gallery and it would prove harder for the delegates . . . to retreat from positions once taken." 946

Contrary to the prime minister's and cabinet's stated goal of avoiding commitments or keeping a modest profile, Pearson was elected chairperson of the First Committee and Canada was appointed to the United Nations Special Committee on Palestine (UNSCOP). ${ }^{947}$ In discussing the appointment of Canada's representative to UNSCOP, St. Laurent told Jack Pickersgill, King's special assistant, that Pearson had a keen interest in serving on the Special Committee. The prime minister, however, was steadfast in opposing Pearson's participation in the work of the UNSCOP Committee. The prime minister had grave misgivings about Pearson. King saw the under-secretary as too young and idealistic. ${ }^{948}$ Besides, King believed that Pearson's appointment to UNSCOP would take the under-secretary away from his duties for too long. ${ }^{949}$ Accepting

945 Anne Hillmer, "Canadian Policy on the Partition of Palestine, 1947” [Unpublished M. A. thesis] (Ottawa: Carleton University, 1981), p. 40.

946 Ibid. Also see: Elizabeth. MacCallum, "Note for Mr. Pearson,” April 21, 1947, Anne Hillmer Papers.

947 Trygve Lie, "Secretary-General of the United Nations Organization to the Secretary of State for External Affairs," May 15, 1947, Anne Hillmer Papers.

948 J. W. Pickersgill and D. F. Forster (eds.), The Mackenzie King Record: Vol. 4, 1947-1948 (Toronto: University of Toronto Press, 1970), p. 140.

949 Eliezer Tauber, Personal Policy Making: Canada's Role in the Adoption of the Palestine Partition Resolution (Westport, Conn.: Greenwood Press, 2002), p. 11. 
Hume Wrong's earlier advice, ${ }^{950}$ St. Laurent proposed to the prime minister that the Canadian representative should be someone acting in a "judicial capacity," and not subject to direction from the government. ${ }^{951}$ St. Laurent provided the prime minister with a short list of seven potential candidates, which included a Supreme Court justice, two provincial chief justices, two senators, an ambassador, and the chancellor of a Canadian university.

The following evening, St. Laurent met with the prime minister to finalize their choice. ${ }^{952}$ King sensed St. Laurent's anxiousness about the appointment. Of the names suggested by St. Laurent, King favoured Ivan. C. Rand, the 63 year-old Supreme Court justice, who had succeeded in arbitrating the recent and costly three-month long strike of Ford's automobile workers in Windsor, Ontario. The prime minister was confident that Rand would provide UNSCOP a fresh perspective on Palestine. On May 22, 1947, an Order-in-Council appointed Justice Rand as Canada's representative to UNSCOP. Léon Mayrand, an experienced Canadian diplomat, was appointed as Rand's alternate. ${ }^{953}$ The Canadians were joined on the Special Committee by John Hood of Australia, Karel

950 Louis St. Laurent, "Secretary of State for External Affairs to the Canadian Ambassador in United States," May 3, 1947, in DCER, Vol. 13, pp. 922-923. Accord to the document, Wrong suggested to St. Laurent that: "if Canada was to accept membership, we should inform the United States and United Kingdom that we would appoint a prominent Canadian to the Committee whom we would expect to act in an independent capacity with instruction or direction from the government. By establishing the principle that the Canadian representative on the Committee was acting in an independent capacity, we would relieve the government of pressure directed towards influencing Canadian policy."

951 J. W. Pickersgill, "Memorandum for the Prime Minister," May 16, 1947, in DCER, Vol. 13, pp. 924925.

952 Ibid, p. 925.

953 “United Nations Palestine Committee: Canadian Representatives,” May 22, 1947, Anne Hillmer Papers. Also see: William Kaplan, Canadian Maverick: The Life and Times of Ivan C. Rand (Toronto: University of Toronto Press, 2009), p. 225. 
Lisicky of Czechoslovakia, Dr. Jorge Garcia Granados of Guatemala, Sir Abdur Rahman of India, Nasrollah Entezam of Iran, Dr. N. S. Blom of the Netherlands, Dr. Alberto Ulloa of Peru, Justice Emil Sandström of Sweden, Professor Enrique Rodriguez Fabregat of Uruguay, and Vladimir Simic of Yugoslavia, ${ }^{954}$ along with Victor Hoo, Ralph Bunche, and a small number of officials from the United Nations Secretariat.

MacCallum had grave reservations about the appointment of Rand. He had neither international relations experience nor expertise in matters of international jurisprudence. Moreover, his understanding and knowledge of Palestine were virtually non-existent. ${ }^{95}$ To address her concerns and to ensure that he was adequately prepared for his duties, the department directed MacCallum to provide Rand with a course in the history of Palestine and the dispute. ${ }^{956}$ With less than ten days before the Committee's work was to begin, MacCallum faced the daunting task of familiarizing Rand with both the historical and cultural perspectives of the dispute in a way that was respectful and balanced. Her central objective in preparing Rand was to demonstrate that partition was not the only solution.

MacCallum began her mentorship of Rand by providing him with a series of articles that she hoped would acquaint him with the work being done by the General

954 United Nations General Assembly, "United Nations Special Committee On Palestine: Report to the General Assembly, Volume 1," United Nations Official Records Of The Second Session Of The General Assembly, A/364, Supplement No. 11, September 3,1947 (Lake Success, New York: United Nations Information Office, 1947), p. 10. The Government of Palestine informed the Committee that it had appointed D. C. MacGillivray to be responsible for liaison with the Committee. The Jewish Agency for Palestine named Abba Eban and David Horowitz as its liaison officers.

955 T. W. MacDermot, "Memorandum," May 23, 1947, Anne Hillmer Papers. MacDermot noted that MacCallum had recommended to him that both Rand and Mayrand seek an expert who thoroughly knew the subject and documentation surrounding the Palestine issue. The comment implied that she was concerned that neither man was sufficiently knowledgeable about the Palestine situation.

${ }^{956}$ Bercuson, Canada and the Birth of Israel, p. 76. 
Assembly. ${ }^{957}$ These documents included articles on UNSCOP's terms of reference and the work of the First Committee. Most of her time, however, was spent on explaining the distinctiveness of both Arab and Jewish cultures. Using her essay, "Historical Background of the Palestine Problem," MacCallum described the central problem confronting the international community. Palestine was the birthplace of two great historic tragedies - one that befell the Arabs seven centuries before, and kept them isolated until the close of the nineteenth century, and the other that had struck the Jews two thousand years before, causing their exodus from Palestine. Both peoples, explained MacCallum, were forced to leave their ancestral homelands by foreign conquerors. Instead of coming to the aid of the Moslems, the European powers watched as the Mongols and then the Turks seized the Moslem lands and subjugated the Arab peoples. Then the Western powers stood still as the Nazis murdered two-thirds of the entire Jewish population in Europe and Africa. ${ }^{958}$

Potent forces of abandonment and betrayal continued to be at work in modern-day Palestine, warned MacCallum. She told Rand that UNSCOP must not ignore the importance of these forces if the two sides were "to be given direction which will neither provoke nor intensify destructive tendencies in the other."959 Throughout MacCallum's mentorship, she attempted to provide Rand an understanding of the challenges confronting UNSCOP. In particular, she wanted him to recognize that alternative

\footnotetext{
${ }^{957}$ Elizabeth MacCallum, "Memorandum for Justice I. C. Rand,” May 30, 1947, Anne Hillmer Papers.

958 Elizabeth MacCallum, "Historical Background of the Palestine Problem," May 31, 1947, p. 1, Anne Hillmer Papers.

${ }^{959}$ Ibid.
} 
solutions existed beyond the ones proposed by the Jewish Agency and the Arab Higher Committee. For MacCallum, the right course was a mutually agreeable solution, not an imposed one.

To ensure that UNSCOP's process remained objective, MacCallum suggested to Rand and the department that the Special Committee needed to secure the advice of independent experts, who could evaluate the information provided by Palestine's provisional government, the Jewish Agency, and the Arab Higher Committee. ${ }^{960}$ The proposals submitted by the Arabs and Jews, insisted MacCallum, would be far from balanced; they were bound to be an extension of their political goals. ${ }^{961}$ By having all information properly vetted and contextualized, UNSCOP's needs would be better served. In particular, she insisted that:

These experts would serve as advisers both to Committee members and to the secretariat. It would be their function (a) to help the secretariat to find quickly all useful material bearing on issues under discussion, (b) to make suggestions regarding the organization and analysis of this material and, (c) to supply the Committee with any relevant data which the three accredited [U.N.] representatives may fail to draw to its attention. ${ }^{962}$

Moreover, MacCallum believed that, if the committee's recommendations were opposed by either of the disputing parties, the independent advisers could strengthen the hand of the committee and prevent the committee members from "wasting their time on the elaboration of proposals attractive enough to minds trained in the Western world but inappropriate to a region in which Moslem and Jewish tradition must be taken into

\footnotetext{
${ }^{960}$ Elizabeth MacCallum, "Memorandum for Mr. Justice Rand,” May 31, 1947, p. 1, Anne Hillmer Papers.

${ }^{961}$ St. Laurent, "Memorandum to the Canadian Consul General."

962 MacCallum, "Memorandum for Mr. Justice Rand," p. 1.
} 
serious account and where the mentality of the people is strongly affected by fears bred of long oppression unfamiliar to the majority of Committee members." $" 963$

MacCallum's recommendation, raising the thorny issue of the Special Committee's ability to distinguish evidence from propaganda, was supported in a letter by Pearson to the secretary-general to the United Nations. UNSCOP members initially were favourable to the idea, but deferred an answer until June $6,1947 .{ }^{964}$ The United Nations Secretariat, the administrative body of the United Nations, appreciated the Canadian suggestion, but the secretary-general thought that it was unnecessary given the fact that the Secretariat's Ralph Bunche had experience in dealing with the problem. ${ }^{965}$ The Secretariat believed that Bunche could provide all the necessary analysis to complete the investigative stage of UNSCOP's mission. ${ }^{966}$ MacCallum strongly disagreed and insisted that the committee could benefit by the addition of independent advisers. Although she respected Bunche's expertise in African affairs, she did not believe that he was competent to advise the Special Committee. MacCallum repeated her judgement that there must be available "several persons who have been following in detail during the last twenty years the output of more than a score of Jewish organizations, the controversies over Palestine policy, which have been carried on in the United Kingdom and the United

\footnotetext{
963 Ibid, p. 2.

964 Louis St. Laurent "Memorandum to the Canadian Consul General,” June 4, 1947, Anne Hillmer Papers.

965 Brian Urquhart, Ralph Bunche: An American Life (New York: W. W. Norton \& Company, 1993), p. 140. Urquhart recognized that Bunche had little experience in Middle East political affairs.

966 Elizabeth MacCallum, "Memorandum to the Canadian Consul-General," June 3, 1947, Anne Hillmer Papers. MacCallum gave this message to Mayrand in a telephone conversation.
} 
States, and the activities of Arab groups concerned with the problem."967 Canadian officials concurred with MacCallum’s assessment.

On June 11, 1947, Riddell proposed to Mayrand another option:

[The] best way of helping to make certain that the Commission would not be misled by inaccurate or inadequate information on the background of its discussions, would be to attach Miss MacCallum herself to the Canadian delegation when it returns to Geneva for the purpose of writing the report. . . Her experience in Geneva would also make her a more useful member of the Assembly delegation when the subject is discussed in New York. ${ }^{968}$

Riddell's recommendation only envisaged an after-the-fact role for MacCallum. It would have limited her part to advising the Canadian delegates. This did not address her principal concern — the influence that faulty information would have on UNSCOP's investigative findings. Knowing that the Jewish Agency was better prepared for the investigation than the Arabs, she feared that UNSCOP members would misjudge or misinterpret the situation on the ground. MacCallum warned of this possibility in "Historical Backgrounds to the Palestine Problem," when she cautioned that the "Arab leadership is less experienced in the ways of democracy than Jewish leaders . . . it may be a temptation to dismiss the former as feudal aristocrats determined chiefly to establish their own position in a rapidly-changing world." 969

\footnotetext{
967 Ibid.

968 R. G. Riddell, "Memorandum for Mr. Pearson,” June 11, 1947, Anne Hillmer Papers.

${ }^{969}$ MacCallum, "Memorandum for Mr. Justice Rand,” p. 3.
} 


\section{The UNSCOP Investigation and MacCallum's Misgivings}

MacCallum's apprehensions were well justified. On June 13, 1947,,$^{970}$ as UNSCOP was about to begin its investigation and hearings in Palestine, Jamal Husseini, the acting chairman of the Arab Higher Committee (AHC) in Palestine, cabled U.N. secretary-general Trygve Lie informing him that, after a thorough study of the deliberations and circumstances surrounding UNSCOP's establishment, and believing that the Special Committee's terms of reference precluded the possibility of a fair judgement, the Palestinian Arabs had decided "to abstain from collaboration with the special committee and to desist from appearing before it. . . ..971 Therefore, stated Husseini, the Arab leadership in Palestine had decided to boycott UNSCOP's investigation owing to the United Nations' decisions not to end the British Mandate and declare Palestine an independent state; to marry the Palestine question to the Jewish refugee crisis in Europe; and to ignore Palestinian Arabs' inherent rights of selfdetermination. ${ }^{972}$ To further demonstrate their resolve, the AHC called for a one-day general strike in the Arab community in Palestine, beginning on June 16, 1947. ${ }^{973}$

\footnotetext{
${ }^{970}$ Robert Macatee, "Consul General in Jerusalem to the Secretary of State," June 11, 1947, in FRUS, 1947 , Vol. 5, p. 1102. Also see: Herbert J. Liebesny and J. C. Hurewitz, "Developments of the Quarter: Comment and Chronology, June 1-August 31, 1947," Middle East Institute, Vol. 1, No. 4 (October, 1947), p. 444. UNSCOP left the United States in two groups, the first group by air on June 10, 1947 via London; the second flew directly to Palestine on June 11, 1947. The two groups reunited in Jerusalem on June 15.

${ }^{971}$ Sami Hadawi, Bitter Harvest: A Modern History of Palestine (New York: Olive Branch Press, 1991), p. 66.

972 Ibid.

${ }^{973}$ Liebesny and Hurewitz, “Developments of the Quarter: Comment and Chronology,” p. 443.
} 
With word of the boycott, ${ }^{974}$ MacCallum judged that the Arabs had made a grave error in judgement. The Palestinian Arab leadership had given away any opportunity to explain their historical connection with the Holy Land, their economic approach to the country's development, and the nature of a largely unknown society. Without direct Arab representation, MacCallum was convinced that Zionist assertions would go unopposed. She also feared that the Arab boycott would sway Rand's and Mayrand's outlook on the Palestine problem. MacCallum was not the only observer who was disheartened by Husseini's decision. Harold Beeley, the British Foreign Office's expert on Palestine, described the AHC's boycott as an example of the Arabs' "'exceedingly inept diplomacy." "975 He believed that it would only increase the sympathy for the Jewish cause, rather than increasing support for Arab nationalism. Even the Arab League and Arab governments considered the AHC's decision foolhardy. As Middle East scholar Fred Khouri explained, the Arab League believed that the AHC's action would foster anti-Arab propaganda and harm the Arab cause. ${ }^{976}$ The League, moreover, knew that it would provide the Zionists an uncontested stage for promoting their position. In order to compensate for the short-sighted AHC decision and minimize the Zionist influence, the League proposed to UNSCOP officials that they hold closed-door hearings in Lebanon and Transjordan. ${ }^{977}$ However, this was too little and too late. By the time the Arab

\footnotetext{
974 “Arab Opposition Hardens," The Economist, June 21, 1947.

${ }^{975}$ Wm. Roger. Louis, The British Empire in the Middle East, 1945-1951 (Oxford: Clarendon Press, 1984), p. 470.

${ }^{976}$ Fred J. Khouri, The Arab-Israeli Dilemma (Syracuse, New York: Syracuse University Press, 1985), p. 45.

977 Liebesny and Hurewitz, "Developments of the Quarter: Comment and Chronology, June 1-August 31, 1947," p. 445.
} 
League presented the Arab perspective to the Special Committee on July 22, 1947, the damage was permanent.

The Special Committee also saw the dangers inherent in the AHC's decision. In an effort to persuade the AHC to abandon its boycott, and provide a cooling off period for both communities, ${ }^{978}$ UNSCOP suspended formal hearings until July 3, 1947. The Jewish Agency made the most of the delay and the Arab decision. As Abba Eban, Jewish liaison officer to UNSCOP, pointed out: "We benefitted greatly from Arab errors in those days. . . ."979 In the two-week period of suspended hearings, UNSCOP members made field trips to the different districts of Palestine. ${ }^{980}$ The Jewish Agency wasted little time in exploiting the AHC miscalculation and the mounting chaos in Palestine. Without opposition, David Horowitz, the Jewish Agency's other liaison officer to UNSCOP, moved to influence the fact-finding phase of the Committee's investigation. He convinced the delegates that it was not fair to visit an equal number of Arab and Jewish factories, since they did not represent the relative strengths of Arab and Jewish industry. ${ }^{981}$ UNSCOP members accepted Horowitz's recommendation and visited a disproportionate number of Jewish industrial enterprises. The impact was almost

\footnotetext{
978 Khouri, The Arab-Israeli Dilemma, p. 44. Khouri stated that Arab, Jewish, and British tensions dramatically increased when UNSCOP arrived in Jerusalem. Jewish terror and illegal immigration activities intensified and reached a postwar high. The Zionists sent the ship "Exodus," with more than 4500 illegal Jewish immigrants aboard, to Palestine. The British seized the ship, and returned the refugees to France. Ultimately, the refugees were sent back to Germany. Zionists were outraged by the British military court's recommendation of the death sentence for three members of Irgun captured during the Acre Prison attack on May 4, 1947. These events had a lasting effect on the UNSCOP members and intensified the anti-British sentiment among some members of the Committee.

979 Abba Eban, An Autobiography (New York: Random House, 1977), pp. 76-78.

980 Léon Mayrand, "Letter to the Under-Secretary of State for External Affairs," July 7, 1947, External Affairs Records, LAC, RG 25, Vol. 3695, File: 5475-CD-1-40C.

${ }^{981}$ David Horowitz, State in the Making (New York: Alfred A. Knopf, Inc., 1953), p. 161.
} 
immediate; delegates saw some of the most modern Jewish businesses and settlements in Palestine. They observed communities that were "European, modern, dynamic . . . a state in the making." ",982

UNSCOP's tour of the settlement of Ruhama was particularly impressive to the committee. The desert community showcased the Jews' ability to convert a portion of the Negev's harsh desert region into useable agricultural land with fresh-water reservoirs. In comparison, the Special Committee was appalled by the working conditions in Arab enterprises. In Haifa, for example, they toured an Arab cigarette factory and found child labourers working under extreme and dangerous conditions. This was abhorrent to Committee members' western sensibilities. ${ }^{983}$ They perceived the Arabs as backward and not ready for statehood. The differences in attitude between the two communities must also have been startling to the Committee members. In Tel Aviv, UNSCOP members were greeted by enthusiastic Jewish crowds; in the central Palestine cities of Ramleh, Jaffa and Jerusalem, UNSCOP met only distain and indifference from the Arabs.

The Arabs fared no better during UNSCOP's public and private hearings in Jerusalem. ${ }^{984}$ With only the Palestine government, the Anglican Bishop of Jerusalem, and some British organizations countering Jewish claims, the Zionists easily overwhelmed the Special Committee with detailed testimonies of their religious, historical, and legal

\footnotetext{
982 Benny Morris, 1948: The First Arab-Israeli War (New Haven, Conn.: Yale University Press, 2008), p. 40.

983 J. C. Hurewitz, The Struggle for Palestine (New York: W. W. Norton \& Company, Inc., 1950), p. 166.

${ }^{984}$ Khouri, The Arab-Israeli Dilemma, p. 44.
} 
rights to Palestine. ${ }^{985}$ Chaim Weizmann, the former head of the Zionist Organization and the Jewish Agency in Palestine, was especially impressive in his presentation to the Committee. ${ }^{986} \mathrm{He}$ affirmed that the partition of Palestine and the establishment of a Jewish State was the proper solution to the Palestine question and the Jewish refugee crisis in Europe. Weizmann drew a vivid picture of the Jewish people as a "homeless and wandering nation, without roots or soil of its own." 987 The AHC, on the other hand, refused to make any formal statement; instead they relied on Sir Abdur Rahman, the Indian Committee representative, to convey their views. ${ }^{988}$ The only substantial statement outlining the Arab case was made in Lebanon in late July by members of the Arab League. On behalf of the six Arab League members, Hamid Bey Franjiyyah, the Lebanese foreign minister, read a joint statement that warned: "“the partition of Palestine and the creation of a Jewish State would result only in bloodshed and unrest throughout the entire Middle East." 989 The Arab strategy was clearly to threaten the Jews and the Great Powers with war in the hopes that it would erode support for a Jewish state.

The reports and testimonies could not compare, however, to what the Committee's delegates saw in Europe. On July 30, 1947, the Committee decided to send a group of seven members to tour some of the Displaced Persons (DP) camps in Germany

\footnotetext{
${ }^{985}$ Robert Macatee, "Memorandum for the Secretary of State," July 14, 1947, in FRUS, Vol. 5, p. 1125.

986 B. M. Williams, “Memorandum for R. G. Riddell,” July 29, 1947, External Affairs Records, LAC, RG 25, Vol. 3695, File: 5475-CD-1-40C. In this memorandum, Williams submitted two copies of Chaim Weizmann's July 9, 1947 testimony before the UNSCOP Committee to Riddell.

${ }^{987}$ Horowitz, State in the Making, p. 173.

988 Ibid.

${ }^{989}$ Hurewitz, The Struggle for Palestine, p. 295.
} 
and Austria. ${ }^{990}$ The effect of the camp inspections on UNSCOP members was invaluable to the Jewish case. In every camp, the Jewish Agency was present; they had initiated education programs, supplied textbooks, and given lessons in Hebrew, ${ }^{991}$ all in an effort to promote Palestine as the future home of the Jewish State. The Agency also effectively used the fear among the Jewish survivors of the growing anti-Semitism in Europe. ${ }^{992}$ Thus, when UNSCOP toured the camps, its members were met by a sea of refugees, all pleading for immediate immigration to Palestine.

The Zionist influence, felt everywhere, was perhaps greatest in their informal, one-to-one discussions with particular members of the Committee. They courted undecided Committee members, chipping away at their reservations about partition until they had won them over. Rand was the chief target of Horowitz's attention. Reading through Léon Mayrand's memoranda to Ottawa, MacCallum must have been deeply concerned about the Zionists' influence on the Canadian representatives. She had secretly suspected that both Canadian representatives to UNSCOP had already moved into the Zionist camp — contrary to her best efforts. ${ }^{993}$ Mayrand had read Richard Crossman's Palestine Mission, and concurred with the author's conclusion that "partition was the only final solution." ${ }^{994}$ Crossman had a profound impact on Mayrand who, with the

\footnotetext{
${ }^{990}$ Léon Mayrand, "Memorandum for the Secretary of State for External Affairs,” July 31, 1947, External Affairs Records, LAC, RG 25, Vol. 3695, File: 5475-CD-1-40C.

${ }^{991}$ Hadawi, Bitter Harvest, p. 66.

992 Ibid, pp. 98-99.

993 Hillmer, "Canadian Policy on the Partition of Palestine," p. 68. This view was expressed during Hillmer's interviews with MacCallum in 1980-81.

994 Richard Crossman, Palestine Mission: A Personal Record (New York: Harper \& Brothers Publishers, 1947), p. 181. Crossman was a member of the British delegation to the Anglo-American Committee of
} 
assistance of his Turkish wife, had helped numerous Jewish families escape Austria during the war. Mayrand later confessed that he recognized many of his own sensibilities in Crossman's testimony. ${ }^{995}$

But it was Rand's attitude that was of greater concern to MacCallum, since he was Canada's principal representative to UNSCOP. ${ }^{996}$ According to historian Anne Hillmer, MacCallum was convinced that, from the time that Justice Rand arrived in Ottawa to prepare for his UNSCOP duties, he had a clear bias favouring the Zionist cause. ${ }^{997}$ Rand had become acquainted with political Zionism well before his appointment to UNSCOP. ${ }^{998}$ His engagement with Zionism, suggested historian Eliezer Tauber, began with his admiration for American Supreme Court Justices Louis Brandeis and Felix Frankfurter, who were prominent in the American Zionist movement. Together they had lobbied President Woodrow Wilson to support the Balfour Declaration. ${ }^{999}$ Rand's respect for Brandeis was furthered in early 1947, when he was given an opportunity to get better acquainted with the man and his cause by reviewing Alpheus

Inquiry into the Problems of European Jewry and Palestine. His study provided a day-to-day description of the Committee's deliberations on the Arab-Jewish problem.

995 Bercuson, Canada and the Birth of Israel, p. 77.

${ }_{996}$ Elizabeth MacCallum, "Memorandum for File,” April 25, 1947, Anne Hillmer Papers.

${ }^{997}$ Hillmer, "Canadian Policy on the Partition of Palestine," p. 68.

998 Tauber, Personal Policy Making, p. 122.

999 Ibid. For greater detail on Louis Brandeis and Felix Frankfurter see: Bruce Allen Murphy, The Brandeis-Frankfurter Connection: The Secret Political Activities of Two Supreme Court Justices (New York: Oxford University Press, 1982); Louis Brandeis, Brandeis on Zionism: A Collection of Addresses and Statements by Louis D. Brandeis (Washington D. C.: Zionist Organization of America, 1942). 
Thomas Mason's 1946 biography, Brandeis: A Free Man's Life, for the Canadian Bar Review. ${ }^{1000}$

MacCallum's concern that Rand was ill-equipped to evaluate the Palestine situation was subsequently confirmed by Horowitz, who recalled that Rand struggled "to determine his own standpoint." 1001 In fact, as David Bercuson noted in Canada and the Birth of Israel, the "Jewish Agency was not sure what to make of Rand."1002 Often, Rand made decisions based on his emotional reading of a situation. For example, when Rand was informed that Horowitz was not permitted to ride with him during the 11-hour car trip to Jerusalem, he became "highly indignant" and verbally abusive of Justice Sandstrom of Sweden, the chairman of UNSCOP. ${ }^{1003}$ Rand ignored the fact that the Committee had already discussed the issue prior to their trip and had decided by a majority vote that it was inappropriate for a Jewish Agency representative to arrive with UNSCOP representatives. It was clear to Horowitz that Rand's "obstinate, fiery, and explosive" personality could be harnessed and exploited. ${ }^{1004}$ Bunche agreed with Horowitz's assessment of Rand. In his opinion, the Canadian representative was the “most irascible, voluble, argumentative old cuss I've ever seen . . . and knows nothing to boot . . . Canada could not possibly have done worse."1005 Bunche's and Horowitz's

\footnotetext{
${ }^{1000}$ I. C. Rand, "Louis D. Brandeis," The Canadian Bar Review, Vol. 25, No. 3 (March, 1947), pp. 240250.

${ }^{1001}$ Horowitz, A State in the Making, p. 167.

1002 Bercuson, Canada and the Birth of Israel, p. 77.

${ }^{1003}$ Ibid.

${ }^{1004}$ Horowitz, A State in the Making, p. 162.

${ }^{1005}$ Urquhart, Ralph Bunche: An American Odyssey, p. 148.
} 
assessments dovetailed with MacCallum's overall view that Rand lacked the proper knowledge of Palestine or the temperament to render a just and balanced verdict.

\section{"Cutting the Palestinian Knot"}

On September 1, 1947, MacCallum's suspicions and fears came to fruition with the release of UNSCOP's 111-page report. ${ }^{1006}$ Its findings included twelve general recommendations, eleven of which were unanimously approved. The report's main recommendations included: the immediate termination of the British Mandate; independence for Palestine after a two-year transitional period; and the preservation of the Holy places. The second part of the report was more contentious. It proposed two settlement schemes: A Plan of Partition with Economic Union, better known as the Majority Plan, and A Federal State Plan, commonly referred to as the Minority Plan.

Sponsored by seven member states - Canada, Czechoslovakia, Guatemala, the Netherlands, Peru, Sweden, and Uruguay — the Majority Plan proposed the creation of an Arab State, a Jewish State, and an International Trusteeship that would administer Jerusalem. The plan recommended a partition scheme that would apportion to the Arabs one-third of Palestine's total area. More precisely, it would provide them with 42.88 percent of the total area, or 4,476 square miles. This territory would consist of three noncontiguous parts: the Western Galilee; the relatively unproductive, poorly irrigated, and densely populated hilly country of Samarra; and Judea. ${ }^{1007}$ The plan allotted 56.47

\footnotetext{
1006 For the Special Committee's report see: UNSCOP, "Report to the General Assembly," September 3, 1947, Vol. 1, A/364 (Lake Success, New York: United Nations Organization, 1947).

1007 “Text of Report on Palestine by U. N. Inquiry Committee: Part II Boundaries,” September 9, 1947, The New York Times, p. C-39.
} 
percent of Palestine's total area to the Jewish State. The new state would also receive three non-contiguous territories: Eastern Galilee; the fertile plains of Esdraedon, considered the breadbasket of Palestine; and the Beersheba sub-district. ${ }^{1008}$ These three parcels of land included both of Palestine's ports in Haifa and Jaffa, most of the country's vital water supply, and the majority of the Arab, as well as Jewish, citrus plantations. With the exception of the Dead Sea potash works, nearly all of Palestine's industry, including those industries set up by foreign enterprises, would be in the Jewish State. ${ }^{1009}$ The proposal was a "good deal more favourable to the Jews than the Peel partition plan [of 1937] had been, and rather less favourable to the Jews than the Jewish Agency scheme submitted to the London Conference." 1010 The majority recommendation in favour of partition, declared historian Wm. Roger Louis, "the UNSCOP majority decision in favour of partition quickly came to represent the cutting of the Palestine knot."1011

The Minority Plan, in contrast, was considered by many a paper scheme - never seriously considered — and yet it reflected the deep-seated differences within UNSCOP. Sponsored by India, Iran, and Yugoslavia, it proposed the creation of an independent, binational state, which would be comprised of a federal government and autonomous self-governing Arab and Jewish provinces. ${ }^{1012}$ According to this proposal, the federal government would exercise full powers over defence, foreign relations, immigration,

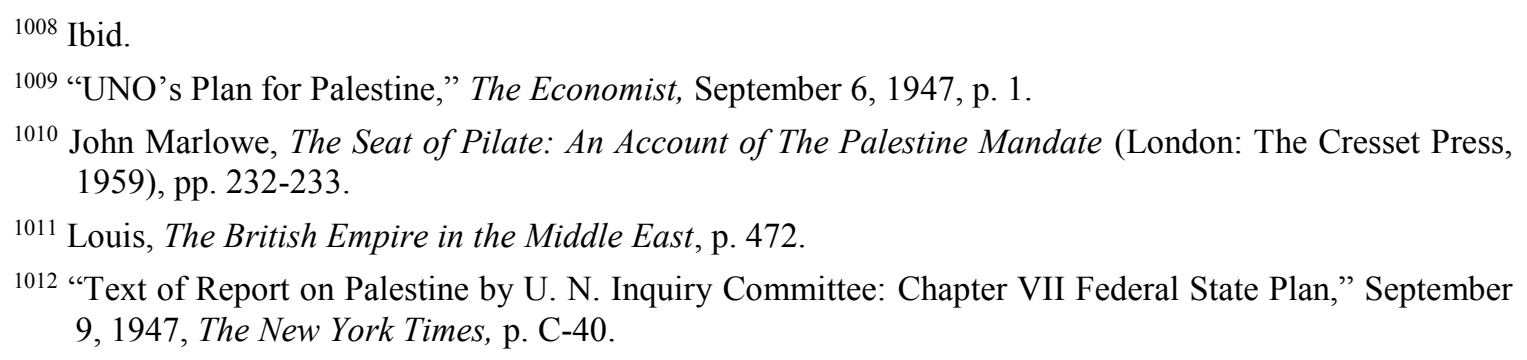
1959), pp. 232-233.

${ }^{1011}$ Louis, The British Empire in the Middle East, p. 472.

1012 "Text of Report on Palestine by U. N. Inquiry Committee: Chapter VII Federal State Plan," September 9, 1947, The New York Times, p. C-40. 
currency, transport, and communications. The Arab and Jewish semi-autonomous governments would enjoy full power over local self-government in its various aspects. The plan envisaged a single Palestinian nationality and citizenship, which guaranteed equal rights for all minorities and fundamental human rights and freedoms, as well as free access to the Holy sites.

The Arab response was universally negative towards both reports. The Arabs were outraged and promised that blood would flow like rivers. ${ }^{1013}$ The Arab Higher Committee rejected partition and expressed its "amazement and disbelief regarding the recommendations that were contrary to the UN Charter and to the principles of justice and integrity."1014 They denounced the Majority Plan, claiming that it "blatantly destroyed the territorial integrity of their homeland; made a 50\% Arab population in the proposed Jewish state officially and permanently subservient to the other $50 \%$ comprising the Jewish population; and gave the latter control over Arab land."1015 The Arab League Council echoed the AHC's denunciation. According to Israeli new school historian Avi Shlaim, Arab resistance to partition "did not stem solely from their objection to the establishment of a Jewish state, but also from their disagreements on what should be done with the Arab part of Palestine" after partition. ${ }^{1016}$

\footnotetext{
${ }^{1013}$ Morris, 1948 , p. 50.

1014 Joseph Nevo, "The Arabs of Palestine 1947-48: Military and Political Activity," Middle Eastern Studies, Vol. 23, No. 1 (January, 1987), p. 26.

${ }^{1015}$ Hadawi, Bitter Harvest, p. 67.

1016 Avi Shlaim, The Politics of Partition: King Abdullah, the Zionists and Palestine, 1921-1951 (Oxford: Oxford University Press, 1990), p. 80.
} 
MacCallum had predicted a significant upsurge in violent demonstrations following the announcement of the UNSCOP recommendations. The escalation in bloodshed and mayhem was not limited to Palestine alone; anger and protests were evident throughout the Arab World. The violence compelled many Arab leaders to toughen their already severe criticism of the United Nations' decision. No Arab leader, recalled Abd al-Rahman Azzam, the Arab League's secretary-general, "could compromise with the Zionists and hope to keep his life, much less his power."1017 Adding to their rejection of the partition plans, Arab leaders threatened the United Nations with a holy war against the Zionists. Fuad Hamza, the Saudi Arabia's ambassador to the United Nations, "warned that the creation of a Jewish state would mean war."1018

Zionist organizations, on the other hand, welcomed the report's findings and recommendations. For many moderate Zionists, the majority plan surpassed all their expectations. It fully recognized their aspirations for a Jewish State. However, not all Zionist groups were satisfied with the outcome. Many were concerned that the report had failed to propose any specific measures for the implementation and enforcement of partition. Irgun, the Zionist paramilitary organization, was the most vocal opponent to the plan. It declared that "'the partition of the Homeland' was 'illegal' and 'would never be

\footnotetext{
${ }^{1017}$ Barry Rubin, The Arab States and the Palestine Conflict (Syracuse, N.Y.: Syracuse University Press, 1981), p. 161.

${ }^{1018}$ Christopher Sykes, Cross Roads to Israel: Palestine from Balfour to Bevin (London: Collins, 1965), p. 386.
} 
recognized. . . .Eretz Israel will be restored to the people of Israel. All of it. And forever." $" 1019$

In the two weeks leading up to and during the second regular session of the General Assembly that commenced on September 16, 1947, pro-Zionist groups in Canada quickly pivoted from distancing themselves from the terrorist activities of Irgun and the Stern Gang to a more offensive diplomatic footing. Zionist organizations, capitalizing on a new-found political momentum, initiated a highly-focused lobbying effort to promote partition. ${ }^{1020}$ Through public statements, rallies, and newspaper editorials, ${ }^{1021}$ they praised the work of Justice Rand and urged Canadians to support the partition plan. ${ }^{1022}$

As part of their campaign, Zionist groups targeted specific External Affairs officials and members of Parliament. In a September 3, 1947 memorandum to Pearson, Ignatieff reported that he had met with Herbert Mowat, formerly with the United Zionist Council, who strongly urged that the under-secretary take the job of chairman of any Palestine Committee that might be struck at the United Nations. ${ }^{1023}$

\footnotetext{
${ }^{1019}$ Khouri, The Arab-Israeli Dilemma, p. 58.

${ }^{1020}$ Bercuson, Canada and the Birth of Israel, p. 107.

1021 Samuel Zacks, "Statement Issued by United Zionist Council of Canada," September 5, 1947, Anne Hillmer Papers. Also see: Marvin Gelber, "Adoption of Palestine Report Advocated," The Globe and Mail, September 15, 1947, p. 6; "U. K. Palestine Policy Scored at Jewish Rally," The Globe and Mail, September 26, 1947, p. 4.

1022 Bercuson, Canada and the Birth of Israel, p. 108. Also see: Zacks, "Statement Issued by United Zionist Council of Canada," p. 1.

1023 George Ignatieff, "Memorandum for the Under-Secretary of State for External Affairs," September 3, 1947, p. 2, Anne Hillmer Papers. Also see: "Shirking Responsibility?," The Globe and Mail, September 17, 1947, p. 2. In this Globe and Mail editorial, St. Laurent was accused of timidity if he prevented
} 
Public reaction in Canada to partition was far from wholly positive. The country appeared divided over what position the Canadian delegation should take at the United Nations. As historian David Bercuson has stated:

[P]ublic reaction to the UNSCOP majority recommendations was marked by apathy, scepticism, and outright hostility: editorials noted that strong Arab opposition to partition was inevitable and that some power or agency would have to enforce it. "If the Jewish terrorists are determined to go on killing," the Calgary Herald observed, "let them try their conclusions with the Arabs, who are not worried about the opinions of other nations."

The views held by Pearson and Riddell were neither ambiguous nor tentative following the release of the UNSCOP report. Beyond the moral and humanitarian imperative of acting on behalf of Jewish displaced persons and refugees, both men firmly believed that Canada and the United Nations had to take a position and act upon it. From a pragmatic perspective, both men believed that Britain's decision to lay the Palestinian question at the feet of the United Nations had made the issue into a Canadian interest. For Riddell, an unresolved dispute represented a clear and present danger to Canada's foreign policy interests. First and foremost, if the United Nations could or would not resolve the Arab-Jewish dispute, one of the world body's key roles — mediating regional disputes would be tarnished. Consequently, it would have a profound effect on the outcome of other regional disputes. Palestine, if left unresolved, would undoubtedly lead to an expansion of the conflict throughout the Middle East and North Africa, and could conceivably involve the intervention of the Great Powers and Canada. Given the Soviet

Pearson from serving as chairman of the Palestine Committee. The editorial also accused the King government of evading its responsibility to Palestine.

${ }^{1024}$ Bercuson, Canada and the Birth of Israel, p. 107. Also see: George Barrett, "Arabs Will Break with West if UN Divides Palestine," The Globe and Mail, September 23, 1947, p. 2; "Consensus on Palestine," The Globe and Mail, October 4, 1947, p. 6. 
interest in establishing a presence in the Mediterranean, concluded Riddell, it was likely that the Russians would exploit and manipulate the Palestine problem to serve their own strategic interests. ${ }^{1025}$ Thus, by early September, Pearson and Riddell had concluded that the only practical and feasible solution to the dispute was the partition of Palestine.

Pearson's and Riddell's early adoption of the partition scheme was evident during the September 2, 1947, meeting of the External Affairs' division heads. Chaired by Riddell and orchestrated by Pearson, the meeting sought the best methods to implement partition. ${ }^{1026}$ Neither the minority plan nor any other scheme was ever seriously considered or explicitly discussed at the meeting. ${ }^{1027}$ Although their support for partition appeared to run contrary to the prime minister's misgivings and his determination to prevent Canada from being drawn any further into the matter, Pearson and Riddell decided to go ahead anyway, taking a gradual approach to supporting partition during the Assembly's deliberations.

MacCallum, on the other contrary, believed that UNSCOP's report was entirely unsatisfactory. It represented for her an unrealistic outcome. Its recommendations had no overarching principles, such as the rights of self-determination or adherence to the Charter. As Loy Henderson, the head of Near East and African Affairs in the U. S. State Department, would later insist, while the Special Committee's report purported to be

\footnotetext{
1025 Bercuson, Canada and the Birth of Israel, pp. 112, 116.

1026 "Meeting of Heads of Divisions," September 2, 1947, External Affairs Records, LAC, RG 25, Vol. 1054, File: 6 .

${ }^{1027}$ Ibid. R. G. Riddell, instead, proposed that the department heads address the government's three policy requirements: a) the policy must not be opposed by the Arabs or Jews; b) the proposal must be practicable, workable, and effective; and, c) the proposal must be consistent with the attitudes of the Great Powers. The first requirement was untenable: the Arabs were resolutely opposed to partition.
} 
impartial, it was full of sophistry, not principle. ${ }^{1028}$ MacCallum was especially disheartened by Rand's role in the report. All of her efforts to instill in Rand a balanced historical, political, and cultural perspective of the Palestinian dispute had been a waste of time. Rand never seriously considered Arab rights. Instead he saw the dispute solely in Zionist terms. He viewed the Balfour Declaration and the Mandate of 1922 only in terms of promises made to the Jews. ${ }^{1029}$ W. H. Cullen, a Canadian trade delegate in Geneva, who had received numerous reports on UNSCOP's deliberations from Mayrand, said that "Justice Rand was by far the main contributor to the partition scheme . . ."1030 His and Canada's seal on the majority report, remarked Horowitz, "was regarded by all as being a powerful factor in the UNSCOP chapter."1031

John Holmes, Canada's acting high commissioner in London, reported in early September 1947 to St. Laurent that the UNSCOP report has had a "bad reception here in the press and in official circles." 1032 Unbeknownst to him and the Canadian government, the British Cabinet had secretly met to decide when and how the United Kingdom should withdraw from Palestine. ${ }^{1033}$ British prime minister Clement Attlee "was determined to liquidate Palestine as an economic and military liability," and as soon as possible,

\footnotetext{
1028 "Excerpts of Minutes of Sixth Meeting of U. S. Delegation to Second Session of General Assembly," September 15, 1947, in FRUS, 1947, Vol. 5, pp. 1149-1150.

${ }^{1029}$ Hillmer, "Canadian Policy on the Partition of Palestine," p. 81.

${ }^{1030}$ W. H. Cullen, "Canadian Trade Delegation in Geneva to the Secretary of State for External Affairs," September 1, 1947, External Affairs Records, LAC, RG 25, Vol. 5475-CD-1-40C, p. 1. Also see: "Canadian Trade Delegation in Geneva to the Secretary of State for External Affairs," August 28, 1947, External Affairs Records, LAC, RG 25, Vol. 5475-CD-1-40C, p. 1.

1031 Horowitz, State in the Making, p. 200.

1032 John Holmes, "Acting High Commissioner in Great Britain to the Secretary of State for External Affairs," September 3, 1947, External Affairs Records, LAC, RG 25, Vol. 5475-CD-1-40C, p. 1.

1033 Morris, Righteous Victims, p. 183. On September 20, 1947, this position was affirmed. For further detail of the meeting see: Louis, The British Empire in the Middle East, pp.473-477.
} 
asserted British historian Wm. Roger Louis. ${ }^{1034}$ The general sentiment towards evacuation did not contradict the Foreign Office's hope to maintain its role in the Arab world. It believed that "Arab goodwill is a much more important strategic factor than a military base in Palestine" and it favoured "getting out in whatever decent and responsible way is possible." 1035

Implicit in Holmes' remarks to Ottawa was the suggestion that Rand's support for the majority plan had undermined the Anglo-Arab relationship. This was substantiated in late 1947 by British foreign secretary Ernest Bevin. During a lengthy meeting at the Dorchester Hotel in London, Bevin spelled out to Mackenzie King the strategic dangers of supporting partition. If Britain was forced to abandon the Arabs and support UNSCOP's partition plan, and if Canada sided with the United States and took up a proZionist position on Palestine, Britain would lose control of Middle East oil and push the Arabs into the arms of the Soviets. ${ }^{1036}$ Knowing the Middle East as well as she did, MacCallum was certain that the Arabs would never accept either the majority or the minority plans, since both schemes rested on partition.

\section{The Ad Hoc Committee and a MacCallum Opportunity}

On September 16, 1947, the United Nations convened the second regular session of the General Assembly in Flushing Meadows. With forty-three items on its agenda,

\footnotetext{
${ }^{1034}$ Louis, The British Empire in the Middle East, p. 474. Also see: Wm. Roger Louis, "British Imperialism and the End of the Palestine Mandate," in Wm. Roger Louis and Robert W. Stookey (eds.), The End of the Palestine Mandate (London: I. B. Tauris \& Co., 1986). According to Louis, the drain on the U.K. economy for military upkeep of Palestine amounted to close to $£ 40$ million per year.

${ }^{1035}$ Holmes, "Acting High Commissioner in Great Britain to the Secretary of State for External Affairs," p. 2.

${ }^{1036}$ Pickersgill and Forster, The Mackenzie King Record, Vol. 4, p. 135.
} 
including the civil war in China, the Korean crisis, the Greek civil war, and the IndianPakistan conflict, Secretary-General Trygve Lie decided on September 23, 1947 against the wishes of the Arabs — to create a separate sub-committee to consider the problem of Palestine in light of UNSCOP's report. ${ }^{1037}$ Lie's decision to create the committee reflected his reaction to the mounting violence in Palestine and the rising rhetoric that was now front and center in the Assembly. With the support of the Assembly's members, Lie's new Palestine Committee, referred to as the Ad Hoc Political Committee, was tasked with making a detailed study of UNSCOP's majority and minority plans, and reporting its recommendations to the Assembly. ${ }^{1038}$ Their meetings began on September 25, $1947 .{ }^{1039}$

On September 19, 1947, less than a week before the Ad Hoc Committee began its deliberations, Pearson met the prime minister and advised King that he was under pressure to accept the nomination as chairperson of the Ad Hoc Committee. ${ }^{1040}$ Poorly hidden in Pearson's statement was his desire to get King's approval that he accept the nomination. The proposed appointment was largely orchestrated by Pearson himself, who

1037 "Editorial Note," in FRUS, 1947, Vol. 5, The Near East and Africa (Washington D. C.: Government Printing Office, 1971), p. 1146. The First Committee was responsible for all political issues.

${ }^{1038}$ Evan Luard, A History of the United Nations Vol. 1, The Years of Western Domination, 1945-1955 (London: Macmillan Press Ltd., 1982), p. 168. Luard stated that in response to the Ad Hoc Committee's creation, the Arab states wished that an advisory opinion of the International Court of Justice on various legal points concerning the British mandate of 1922, and the competency of the General Assembly to impose partition on a majority population.

1039 Tauber, Personal Policy Making, p. 29. The Committee had three items on its agenda: (a) Britain's original request, (b) the UNSCOP report, and (c) a proposal put forward by Saudi Arabia and Iraq to establish a unitary Arab state in Palestine.

${ }^{1040}$ Ignatieff, "Delegation to Atomic Energy Commission of the United Nations to the Under-Secretary of State for External Affairs," September 3, 1947, LAC, External Affairs Records, RG 25, Vol. 5475, CD-1-40C, p. 2. Ignatieff informed Pearson that Herbert Mowat of the World Committee for Palestine has "expressed the hope that you would be able to take on the chairmanship of the Palestine Committee in the Assembly...." 
wanted to be in the center of the Ad Hoc Committee's deliberations. ${ }^{1041}$ King rightly sensed in Pearson an eagerness to accept the post. ${ }^{1042}$ Suspicious of Pearson's judgments in the Palestine matter and fearful that his adventurous under-secretary would drag Canada further into the Palestinian debacle and force the country to take on more than it should, King told Pearson that it would be unwise to accept the nomination, if it could be avoided. He voiced his concern that, with Pearson's lengthy absence from Ottawa, the burdens of the department would fall squarely on St. Laurent's shoulders. The pressure on St. Laurent, said King, would be increased in the prime minister's absence, as he was leaving on October 1, 1947, to attend the royal wedding of Princess Elizabeth in London, which was scheduled for November 20, 1947. King feared that Canada would be drawn into a Middle East political conflict — a place where Canada had no direct interest. ${ }^{1043}$ Furthermore, Pearson's active participation would most certainly sacrifice Canada's overall influence at the United Nations, thought King. ${ }^{1044}$ No longer would Canada be seen as impartial. Also vexing to King were the domestic implications of Pearson's appointment. His government would come under ever-increasing pressure by all the

${ }^{1041}$ R. G. Riddell, "Memorandum to the Secretary of State for External Affairs," August 30, 1947, p. 2, External Affairs Records, LAC, RG 25, Vol. 5475, CD-1-40C. In this memorandum, Riddell informed Ignatieff that "Mr. Pearson will be available for Chairmanship of Special Committee on Palestine if such were established. I think it may be assumed also that he would be available for Chairmanship of section of Committee 1 dealing with Palestine. ..." Riddell also indicated that St. Laurent was firmly against Pearson's appointment to the Chairmanship of Ad Hoc Committee. Also see: Bercuson, Canada and the Birth of Israel, p. 112. Bercuson stated that: "it became clear in Ottawa that Washington was going to press Pearson to become chairman of this committee...."

1042 King Diary, September 19, 1947, p. 3.

${ }^{1043}$ Ibid. King expressed this view privately to Bevin. "Canada's role was not that of Sir Galahad to save the whole world unless we were in a position to do it."

${ }^{1044}$ King Diary, September 19, 1947, p. 3. 
parties involved. The under-secretary would surely "offend one section of the public opinion."1045

Following his meeting with Pearson, King telephoned St. Laurent in New York instructing his foreign minister not to allow Pearson to be nominated. King stated that this would not only lead to St. Laurent's and the government's embarrassment, but would be a grave mistake for Pearson's career. To the great relief of the prime minister, Dr. Herbert Evatt, Australia's foreign affairs minister, was unanimously selected as the Ad Hoc Committee's chairperson. ${ }^{1046}$ King was nevertheless still concerned about Pearson's role in the Committee's deliberations. He decided to appoint James Lorimer Ilsley, the justice minister, as the acting head of the delegation to the UN. Ilsley was one of King's most trusted ministers. Ilsley's appointment was intended to clip Pearson's wings and relegate him to a secondary role in the Ad Hoc Committee's deliberations. ${ }^{1047}$ Yet Ilsley knew nothing of the Middle East and lacked an appreciation of the intense "pro- and antiZionist manoeuvring that inevitably went on at the United Nations." 1048 This would be Pearson's delegation. His authority was reinforced by a loyal cadre of supporters Riddell, Ignatieff, and Mayrand. The unifying thread that tied this group together was their personal commitment to partition and the creation of a Jewish State, which they all considered a sine qua non of any settlement.

\footnotetext{
1045 Ibid.

1046 King Diary, September 25, 1947, p.1.

${ }^{1047}$ Bercuson, Canada and the Birth of Israel, p. 112. 1048 Ibid.
} 
As the Ad Hoc Committee's deliberations were to begin, the British government sent a memorandum to St. Laurent indicating its general support for UNSCOP's recommendations, the call for the end of the Palestine Mandate in particular. However, Britain's support for UNSCOP's majority plan came with a large caveat. Britain reserved the right to decline the task of "implementing proposals which would demand use of force and which could not be reconciled with our conscience." ${ }^{1049}$ More precisely, the British refused to implement a settlement that was not supported by one or both parties. If a settlement could not be reached and the General Assembly was determined to impose the partition plan by force if necessary, Britain would immediately withdraw its troops from Palestine. This set an ominous context for Canada's policy and the upcoming Ad Hoc Committee's deliberations, which were scheduled to commence on September 25, 1947. To make its point, Britain sent its colonial secretary, Arthur Creech-Jones, to deliver its message to the Ad Hoc Committee's inaugural meeting. He said that British policy was neither to endorse nor criticize the majority and minority reports, but to remain neutral. He nevertheless warned that Britain could not countenance a plan that did not have the full support of both Arabs and Jews. Creech-Jones concluded his statement dramatically. He announced his government's decision to "plan an early withdrawal of the British forces and of the British administration in Palestine." ${ }^{1050}$ Britain's decision startled and shocked many of the delegations. The assumption until now, suggested Anne Hillmer, "'had been that the mandatory power would remain in Palestine until the

\footnotetext{
1049 "Secretary of State for External Affairs to the Canadian Consulate General," September 23, 1947, External Affairs Records, LAC, RG 25, Vol. 1057, File: 2-4-0, p. 1.

${ }^{1050}$ Hillmer, "'Here I am in the Middle,"” pp. 127-128.
} 
situation was resolved and arrangements were completed for a future government." ${ }^{1051} \mathrm{~A}$ new framework was undoubtedly necessary, one that was presumably based on negotiation not imposition.

From the moment that he arrived in New York, Ilsley made it known that he was concerned by the unrestrained pro-Zionist attitude evident among the members of the Canadian delegation, which had led them to promote, prematurely, a position whose case had not yet been made. ${ }^{1052}$ He felt that Pearson and Riddell had jettisoned important ethical and moral considerations for short-term pragmatic gains. In particular, he thought that they had given too little thought to the rights of Palestinian Arabs in their calculations. He warned them that he would not support partition until he had thoroughly studied the problem. Consequently, he turned to MacCallum to hear her point of view. ${ }^{1053}$

The appointment of Ilsley gave MacCallum an opportunity to voice her strong views. On the one hand, she welcomed his approach to her and to Arab rights. Any solution that the United Nations would broker must seriously consider the rights of the Arabs. On the other hand, there had to be serious misgivings about the minister. Ilsley, like Justice Rand, was ill-prepared and uninformed. He knew nothing about Palestine's past or the intricacies of the present Arab-Jewish dispute. MacCallum was determined to be much more assertive in her pronouncements than she had been with Rand. In an October 2 note to Ilsley, she suggested that Canadian officials might have jumped to an

\footnotetext{
1051 Ibid.

1052 Tauber, Personal Policy Making, p. 89.

${ }^{1053}$ Bercuson, Canada and the Birth of Israel, p. 111.
} 
ill-formed conclusion that partition was the only practicable solution to resolving the Palestine dispute. ${ }^{1054}$ She stressed that partition was not the only way to resolve the Jewish refugee crisis, nor were the positions held by the Arabs and Jews wholly intractable. Although more difficult in the short-term, she admitted, alternative solutions had a reasonable chance of success and should be investigated.

MacCallum insisted that Palestine was not the only location where Jewish refugees could be resettled. She told Ilsley of her discussions with Dr. Israel Steinberg of the Freeland League for Jewish Territorial Organization, and David Kessler, editor of the London-based weekly newspaper, the Jewish Chronicle. ${ }^{1055}$ She described Dr. Steinberg's efforts to establish a Jewish settlement of 30,000 in the Republic of Surinam, in the northern part of South America. She also mentioned the British government's efforts "to admit a considerable number of Jewish refugees to British Honduras."1056 According to Kessler, a moderate Zionist, said MacCallum, there was strong support among many Jewish groups for a binational state in Palestine. By communicating the views of Steinberg and Kessler, MacCallum hoped to convince Ilsley that other options existed that did not require usurping the lands and the rights of Palestinian Arabs.

\footnotetext{
1054 Elizabeth MacCallum, "Note for Mr. Ilsley," October 2, 1947, External Affairs Records, LAC, RG 25, Vol. 1057, File: 2-4-0.

1055 Michael Blakeley, "Proposals for a Jewish Colony in Australia: 1938-1948," Jewish Social Studies, Vol. 46, No. 3-4 (Summer-Autumn, 1984), p. 280. In 1935, the Freeland League for Jewish Territorial Organization was created. It immediately commenced a study of the possible areas — under the British flag - for a large-scale settlement of Jewish refugees. Also see: Leonard Stein, The Balfour Declaration (New York: Simon and Schuster, 1961), pp. 3-4.

1056 MacCallum, "Note for Mr. Ilsley,” p. 1.
} 
On October 3, 1947, MacCallum wrote Ilsley explaining some of the difficulties and risks associated with the implementation of partition. Recounting a luncheon meeting that she had had with Dr. Kernkamp of the Netherlands delegation, Paul Alling, a former member of the Near Eastern Division of the U. S. State Department, and Harold Beeley, the Foreign Office's Palestine expert, MacCallum reported that these Middle East specialists believed that the time was not right for implementing partition or for establishing a temporary Trusteeship. "No one present seemed to think a United Nations Trusteeship would be operable or that any western state would accept responsibility for administering Palestine in the transition period."1057 She stressed that no one at the table believed that the majority report could be enforced in the absence of some agreement among the Jews, Arabs, and the Great Powers. The consensus of the meeting, said MacCallum, was that the issue of partition should be delayed for at least two years or until some agreement between the Arabs and Jews could be concluded. Without such an accord, she added, the establishment of a Trusteeship during the transition period would be virtually impossible without enlisting the use of force. Kernkamp, Alling, and Beeley also suggested to MacCallum that it was very likely that the vacuum created by the British decision to withdraw from Palestine would be filled by Zionist and Arab militants. ${ }^{1058}$ According to these experts, said MacCallum, the first priority should be cleaning out the displaced persons' camps as soon as possible. ${ }^{1059}$ In making a case for delay, MacCallum tried to convince Ilsley that Canadian policy should focus on

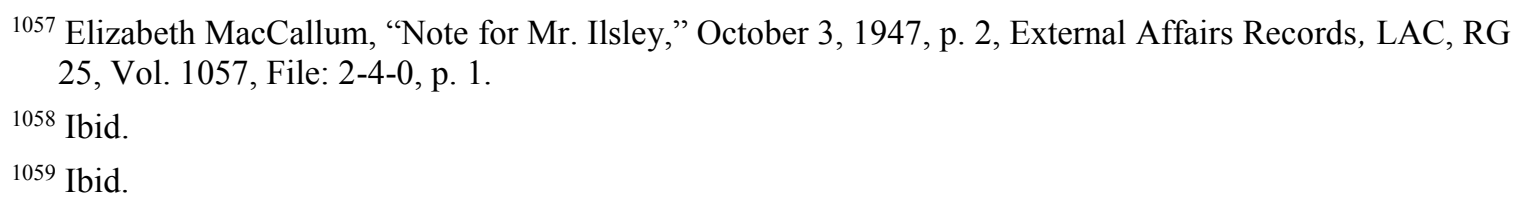


detaching the Jewish refugee crisis from the political issue of Palestine. This, in her view, would reduce some of the tensions in Palestine and demonstrate to the Arabs that they would not have to bear the full brunt of Jewish immigration needs.

In an October 7, 1947 memorandum to Ilsley, MacCallum returned to the difficult issue of implementing partition. She suggested that partition would place a heavy burden on the United Nations. She also suggested that the Assembly's first consideration should be to decide whether Chapter XII of the Charter was applicable to Palestine. ${ }^{1060}$ In other words, should the United Nations attempt to place Palestine under an International Trusteeship? While not MacCallum's first choice, an International Trusteeship was definitely preferable to imposing partition by force. It would reduce the violence and provide an opportunity for both parties to negotiate a fair and just settlement.

At the same time that MacCallum was warning Ilsley about the risks of partition, Pearson was preparing Canada's statement to the Committee. He directed Riddell to have MacCallum and Rand prepare draft statements on Palestine. There is no evidence that Justice Rand prepared a statement over and above the post-UNSCOP memorandum that he wrote in late August or early September of $1947 .{ }^{1061}$ MacCallum, however, laid out the problems of partition, implementation, and enforcement. She contended that, like Canadian public opinion, the international community's views were deeply divided over the question of partition. She rejected the Zionist contention that a Jewish State was the

\footnotetext{
${ }^{1060}$ Canada, Report on the United Nations Conference on International Organization, Conference Series, 1945, No. 2 (Ottawa: The King's Printer, 1945), pp. 49-50.

1061 Ivan Rand, "Memorandum by Mr. Rand," [August/September 1947?], External Affairs Records, LAC, RG 25, Vol. 5475-CD-2-40C, Part 2. Also see: Hillmer, "Canadian Policy on the Partition of Palestine," p. 102 .
} 
proper recompense for the age-old problem of anti-Semitism in Europe; that it would ensure that never again would the Jewish people have a minority status in a country; that it was the only hope for the security of the Jewish community; and it was the only sure foundation upon which the Jewish people could build their future. ${ }^{1062}$ MacCallum further suggested that these rationales ignored the democratic rights of the majority population in Palestine, and the commitments that the Mandate agreement of 1922, the League of Nations Covenant, and the United Nations Charter had made to the Arab people.

By curtailing the Arab right of self-determination that was enshrined in the Charter, declared MacCallum, the new Jewish State would acquire new enemies, continued insecurity, the unending need for a Great Power to ensure its existence, and the constant danger of conflict with its Arab neighbours. MacCallum believed that these threats could lead to the ultimate destruction of the Jewish state. ${ }^{1063}$ Therefore, before any consideration of the majority or minority plan was contemplated, she declared that "it is our first duty to see if an Arab-Jewish agreement can be reached." ${ }^{\prime 064}$ She maintained that she had already witnessed, as had other delegates, the softening of the Arab and Jewish positions in the face of the realities of the changing circumstances. ${ }^{1065}$ MacCallum was convinced that there were too many variables being left unexplored. A hasty decision on any specific plan was unwarranted.

\footnotetext{
1062 Elizabeth MacCallum, "Palestine,” October 9, 1947, External Affairs Records, LAC, RG 25, Vol. 1051, p. 1.

1063 Ibid, pp. 1-2.

1064 Ibid, p. 4.

1065 Ibid, p. 5. MacCallum claimed that: "various members of several delegations have had by now, in private conversations with Jewish and Arab leaders, sufficient evidence of a desire on both sides for conciliation within reasonable limits. ..."
} 
On October 9, MacCallum and Ignatieff were directed to prepare a second draft statement regarding the UNSCOP report. ${ }^{1066}$ As the second draft was being prepared, the Palestine question became a lot more complicated for the Canadian delegation. On October 11, after weeks of consultation between the State Department and White House officials, ${ }^{1067}$ Herschel Johnson, the U. S. ambassador to the United Nations, addressed the Ad Hoc Committee regarding his government's position on Palestine. On behalf of his government, Herschel pledged support for the "basic principles of the unanimous recommendations and the majority plan which provided for partition and immigration." "1068 Johnson also noted that the transition period might require the establishment of a police force recruited on a volunteer basis. In addition to the ambassador's statement, the U. S. delegation submitted a proposal that called upon the committee to establish a sub-committee to:

draw up a detailed plan for the future government of Palestine in accordance with the basic principles of the unanimous recommendations and the majority plan of the United Nations Special Committee on Palestine ... to incorporate this plan in the form of recommendations ... [and to] transmit these recommendations to the Ad Hoc Committee on the Palestine question not later than 27 October $1947 .^{1069}$

Johnson's statement and proposal reaffirmed Truman's determination to keep the U.S. out of the line of fire. More precisely, the United States was not going to "pick up

1066 R. G. Riddell, "Memorandum for the Secretary of State for External Affairs," October 13, 1947, External Affairs Records, LAC, RG 25, Vol. 1057, File: 2-4-0.

1067 See: State Department, "Excerpts from the Minutes of the Sixth Meeting of the United States Delegation to the Second Session of the General Assembly: Position on Palestine," September 15, 1947 , in FRUS, 1947 , pp. 1147-1154.

1068 "Editorial Note," in FRUS, 1947, p. 1180. For text of the statement, see State Department, State Bulletin, October 19, 1947, p. 761.

1069 “Editorial Note," p. 1181. 
the British responsibility for law and order. ..."1070 As Truman saw it, as the mandatory power, it was Britain's responsibility to enforce partition until the Arab and Jewish states came into being. ${ }^{1071}$ The British regarded Johnson's statement as little more than a political declaration of support for the establishment of a Jewish state. It lacked any real substance regarding how partition would be implemented, and more importantly, how it was to be enforced. In Anne Hillmer's words, "The British and Americans had therefore decided on similar positions. Both sought to avoid having the UN recommendations associated with their government; both wished to avoid being directly involved in the implementation and enforcement of a partition. . .."1072

Two days later, Semen Tsarapkin, the Soviet ambassador to the United Nations, responded to Johnson's statement by telling the Ad Hoc Committee that his government supported the partition of Palestine. ${ }^{1073}$ This was a shock to many Western observers and delegations, the assumption being that the Soviets would support a binational state in Palestine. ${ }^{1074}$ Tsarapkin stated that, given the ongoing violence in Palestine, the minority

\footnotetext{
${ }^{1070}$ Forrest Pogue, George C. Marshall: Statesman, 1945-1959 (New York: Viking Penguin Inc., 1987), p. 349.

${ }^{1071}$ Hillmer, “"Here I am in the Middle,"” p. 128.

1072 Hillmer, "Canadian Policy on the Partition of Palestine," p. 100.

${ }^{1073}$ Ibid.

1074 Samuel K. C. Kopper, "Memorandum of Conversation," October 3, 1947, in FRUS, 1947, p. 1171. Meeting with members of the Arab delegation, Samuel Kopper, special adviser to the U. S. delegation, reported that on October 1, 1947, the Soviet delegation offered the Arab states support on Palestine if the Arab states in return would support Ukraine's case to be a non-permanent member of the Security Council. Later that day, the Arab states were approached by the Polish delegation, speaking for the Soviet bloc, "with a request that the Arab states shift their votes to the Ukraine in order to preserve: (1) the effectiveness of the UN, and (2) the logical geographic distribution on the SC." The Arabs made it clear that, if necessary, they would go as far even to support the Soviets on the Greek question and Korea, and any other subjects necessary, to obtain a Soviet commitment to support the Arab position against the establishment of an independent Jewish state.
} 
plan appeared impracticable. He believed that partition offered a better chance of success. $^{1075}$

"Greatly displeased" by the American position, in so far as the United States expected Britain to carry responsibility for implementing partition, Arthur Creech-Jones called for a secret meeting of the Commonwealth delegations on October 13 to discuss partition. The secretary of state for the colonies reaffirmed his government's position; that is, London would withdraw from Palestine rather than support a partition plan that did not have the consent of both the Arabs and Jews. Creech-Jones believed that withdrawal would compel the Arab and Jewish leaders to negotiate a solution. ${ }^{1076}$ Partition, insisted the colonial secretary, would only prejudice the situation and prevent co-operation. South Africa's and New Zealand's delegates voiced similar concerns about partition and its enforcement. When asked by Creech-Jones what Canada's position on partition was, Ilsley replied that, until the Arab case was adequately answered, it was difficult to say what particular position Canada would take. ${ }^{1077}$

On October 13, the second draft statement was completed and sent to Pearson in Ottawa, ${ }^{1078}$ along with a note from Riddell summarizing MacCallum's criticisms of the new statement. ${ }^{1079}$ Perhaps because of MacCallum's opposition, the statement was

\footnotetext{
${ }^{1075}$ Hillmer, “"Here I am in the Middle,” p. 128.

1076 George Ignatieff, "Summary of Commonwealth Meeting," October 13, 1947, External Affairs Records, LAC, RG 25, Vol. 5745, File: 47-B (S).

1077 Ibid, p. 3.

1078 George Ignatieff and R. G. Riddell, "Statement on Palestine," October 13, 1947, External Affairs Records, LAC, RG 25, Vol. 5745, File: 47-B (S), Part 2, p. 1.

1079 R. G. Riddell, "Memorandum for the Secretary of State for External Affairs," October 13, 1947, External Affairs Records, LAC, RG 25, Vol. 5745, File: 47-B (S), Part 2.
} 
authored by Riddell and Ignatieff. Their draft statement recommended that, after a careful examination of the UNSCOP report, the Canadian delegation accepted in general terms "the twelve recommendations which embody the essential principles given as a basis for the conclusions contained in the report." In accordance with UNSCOP's recommendation, the Ignatieff-Riddell draft statement urged the termination of the British Mandate as soon as possible, the granting of independence to Palestine, and the immediate clearing out of the refugee camps. ${ }^{1080}$ The statement added that this thinking was in accordance with the view expressed by a majority of the Ad Hoc Committee members. The draft statement went on to say that Canada did not "regard partition as a permanently satisfactory arrangement . . . but partition appears to us the only solution obtainable at the moment." 1081 The statement concluded that the partition plan was now considered by a majority of delegations as a de facto policy. The two officials in effect recommended, therefore, that the Canadian government accept the majority report as the basis for discussion in the Ad Hoc Committee. ${ }^{1082}$

MacCallum insisted that the Ignatieff-Riddell statement deliberately disregarded democratic principles. Expediency, she said, "can hardly be brought forward as the reason for supporting partition. ..."1083 She feared that it would only energize Arab opposition and embolden Jewish leaders. Riddell also restated MacCallum's concern about the dangers of allowing the United Nations to acquiesce in further Zionist demands

\footnotetext{
1080 Ignatieff and Riddell, “Statement on Palestine,” October 13, 1947, p. 1.

${ }^{1081}$ Ibid, p. 2.

1082 Ibid, p. 2.

1083 Riddell, "Memorandum for the Secretary of State for External Affairs," October 13, p. 1.
} 
to amend the borders beyond what was recommended in the UNSCOP report. This would only reinforce Arab suspicions of Zionist intentions and could provoke a general war that would draw in the Great Powers, claimed MacCallum. Instead of accepting partition as a de facto policy, MacCallum believed that Canada and the United Nations should retreat from the recognition of the Biltmore Program and accept the Balfour Declaration, as defined in Churchill's White Paper of 1922. ${ }^{1084}$ The benefit of this approach was that it would go a long way towards emptying the displaced person camps, settling down tensions in Palestine, and creating an environment where much more useful negotiations between Arabs and Jews could take place. MacCallum, according to Riddell's memorandum, stressed the importance of developing global solutions to the Palestine problem. She recommended an international agreement, under the aegis of the United Nations, which would assure Jewish peoples equal status in all countries. She also suggested that the United Nations could negotiate a fair and equitable immigration quota for Palestine, and a uniform application of regulations relating to immigration, travel documents, and shipping. ${ }^{1085}$

MacCallum's resistance to, and Pearson's and Riddell's support for, partition led to tensions within the Canadian delegation. Her criticisms and observations found fertile ground in Ilsley's attitude to the Palestine problem, which placed him at odds with Pearson and Riddell. Her numerous memoranda to Ilsley encouraged a much more measured approach than Pearson's method offered. The crux of her message was

\footnotetext{
${ }^{1084}$ R. G. Riddell, "Memorandum for the Under-Secretary of State for External Affairs,” October 13, 1947, External Affairs Records, LAC, RG 25, Vol. 1057, File: 2-4-0.

1085 Riddell, "Memorandum for the Under-Secretary of State for External Affairs," p. 2.
} 
repeatedly that Canada needed to examine and assess all of the available alternatives to partition before committing itself to any decision that would adversely affect the whole Middle East and Canada's relationships with the Great Powers. She wanted Canada to make a more concerted effort in pressing the Arab and Jewish representatives to work out a mutually satisfactory solution. If partition was taken off the table, argued MacCallum, both parties would be forced to negotiate a solution. If partition was adopted, greater civil unrest in Palestine would occur and the United Nations would be forced to intervene. Such an intervention would undoubtedly compel Canada's involvement. These warnings substantiated and fortified Ilsley's growing doubts about partition, leading him to try to put the brakes on Canada's support for partition and Jewish statehood.

Ilsley's reactions to the Ignatieff-Riddell statement were caustic. He saw a patently empirical argument that side-stepped all moral and legal responsibilities and considerations. ${ }^{1086}$ The Ignatieff-Riddell statement, in his judgment, was little more than a blueprint of how to implement partition, not whether it should be implemented. ${ }^{1087}$ The statement proposed to the Ad Hoc Committee the steps that Canada believed were needed to work out the details of the partition plan — who should take responsibility for the administration of Palestine during the transitional period, and how partition should be put into effect in the absence of an agreement between the Jews and Arabs. ${ }^{1088}$ To meet these ends, the draft statement proposed the establishment of two sub-committees, one of which would work out "quickly and efficiently" a plan that the United Nations could

\footnotetext{
${ }^{1086}$ Bercuson, Canada and the Birth of Israel, p. 117.

${ }^{1087}$ Ignatieff and Riddell, "Statement on Palestine," October, 13, 1947, p. 1.

1088 Ibid, p. 3.
} 
adopt and the other that would study the problems concerning responsibilities for administration during the transition period and the complications associated with partition's implementation. ${ }^{1089}$ Each sub-committee would examine and refine the respective majority and minority plans. At no point did the Canadian statement propose that there were alternatives available to the General Assembly. As a result, Ilsley rejected the statement.

St. Laurent and the King cabinet did not share either MacCallum's or Ilsley's viewpoints or concerns. Riddell's statement was approved and Ilsley was instructed to deliver it to the Ad Hoc Committee. ${ }^{1090}$ This, however, was not done before MacCallum added to the Canadian statement. In the revised version, a paragraph was inserted, which stated:

There has been much discussion of the principle of self-determination and of the units and groups to which this principle should apply, much debate on the character, the interpretation and the priority of the commitments. None of these considerations have been ignored. . . .We have come to the conclusion, not without much hesitation and concern, that the dominant consideration is a practical one. ${ }^{1091}$

While MacCallum's efforts fell short of her aim of producing a change in Canada's overall attitude to partition, her amendments did soften Canada's exposure to Arab

\footnotetext{
${ }^{1089}$ Ibid, p. 4.

1090 Tauber, Personal Policy Making, p. 96.

${ }^{1091}$ R. G. Riddell, "Memorandum for the Secretary of State for External Affairs," October 14, 1947, External Affairs Records, LAC, RG 25, Vol. 1057, File: 2-4-0, p. 2.
} 
criticisms. No longer would the Canadian government avoid the question of Arab rights of self-determination. ${ }^{1092}$

On the afternoon of October 14, Ilsley delivered the text of Riddell's statement to the Ad Hoc Committee. Ilsley's speech “stressed the need for a solution to Palestine's difficulties that was practicable and constitutional." He described the need to determine the arrangement that would " "best enable two peoples living within the confines of a restricted geographical area to avoid obstructing one another's development and most conducive to their welfare and freedom." 1093 After outlining the goals of the majority and minority plans, Ilsley proposed the establishment of the two sub-committees that would study and make recommendations on the two plans. At the heart of Ilsley's speech was the concern about the United Nations' authority to take over Palestine when Britain withdrew from the Mandate. The Canadian delegation had accepted, "somewhat reluctantly, the majority proposals, at least 'as a basis for discussion." "1094 The Canadian statement was an amendment to the American proposal, stating that, in addition to subCommittee one's drafting of a detailed plan, it should consider "the exercise of administrative responsibility in Palestine during the transitional period," and consider "methods by which recommendations of the Ad Hoc Committee on the Palestine question

1092 Elizabeth MacCallum, "To the General Assembly of the United Nations,” October 16, 1947, External Affairs Records, LAC, RG 25, Vol. 1049: no file number, p. 2.

1093 Anne Hillmer, "“Here I am in the Middle,"” p. 130.

1094 Ibid. 
... would be put into effect." ${ }^{1095}$ The two sub-Committees were struck, and Canada took a seat in sub-Committee one, better known as Working Group 1.

\section{The Ascendance of Pearson, and MacCallum's Continued Opposition}

On October 15, Ilsley was called back to Ottawa. According to a February 1977 interview with MacCallum, Pearson had “engineered Ilsley's temporary recall to Ottawa." 1096 Pearson was now left unchallenged in New York. He was completely in control of Canada's Palestine policy and the delegation. ${ }^{1097}$ While MacCallum's influence seemed marginalized by Ilsley's departure, she was not deterred or intimidated. MacCallum dispatched a memorandum to Escott Reid, head of the second political division and alternative representative to the Second Session of the General Assembly, voicing her concerns about Canada's position. ${ }^{1098}$ She contended that the government's position was far from clear. Was it proposing that the General Assembly accept the majority plan outright or as a basis for discussion? Ilsley’s speech, explained MacCallum, committed the Canadian government only to the latter. ${ }^{1099}$ She also doubted the wisdom of establishing two sub-Committees. MacCallum knew that the purpose of the two subCommittees was not to find a middle course between the majority and minority plans, but to develop the means by which to impose a settlement on the losing side - controversial

\footnotetext{
1095 "Editorial Note," in FRUS, 1947, p. 1181.

${ }^{1096}$ Hillmer, “"Here I am in the Middle,"” p. 130.

1097 John English, Shadow of Heaven: The Life of Lester B Pearson, 1897-1948, Vol. 1 (Toronto: Lester \& Orpen Dennys Publishers, 1989), p. 325.

1098 Elizabeth MacCallum, "Memorandum for Escott Reid,” October 16, 1947, External Affairs Records, LAC, RG 25, Vol. 1057, File: 2-4-0, p. 1.

${ }^{1099}$ MacCallum, "Memorandum for Head of Second Political Division," p. 2.
} 
democratic principles, in her view. She also knew that, since the delegates comprising each sub-committee would be made up of partisan supporters of one side or the other, no impartial majority existed. The recommendations that emerged from the sub-committees' deliberations were bound to be prejudicial and polarizing.

Why then did Pearson not silence MacCallum's dissenting voice, and send her back to Ottawa, or at least restrict her activities at Flushing Meadows to Trusteeship issues? The most likely reason was that she was useful to him and to Canada. Pearson respected her assessments of the Arab-Jewish conflict, although he believed that she did not recognize the larger political and geo-strategic picture. ${ }^{1100}$ Her presence, especially behind the scenes of the Ad Hoc Committee's deliberations, had been noticed and valued by many of the delegations - those of Britain, the Netherlands, and the Arabs. Nevertheless, in an interview with David Bercuson, MacCallum stated, off the record, that:

Pearson tried to take advantage of her impaired hearing, which caused her to become weary in the late hours, scheduling the delegation meetings for the evenings, in the hope that she would not attend and thereby save the delegation her antipartition views. ${ }^{1101}$

On October 17, 1947, the Ad Hoc Committee's general debate on Palestine came to an end, following the speeches of the Jewish Agency and the Arab Higher Committee. MacCallum outlined for Reid the likely outcome of the Committee's vote. She estimated that fourteen delegations would line up in favour of majority plan, and thirteen

\footnotetext{
${ }^{1100}$ Tareq Ismael, "Interview with Lester Pearson," recounted to author by Professor Ismail in a telephone conversation of June 2013.

${ }^{1101}$ Tauber, Personal Policy Making, p. 91.
} 
delegations — mostly Middle Eastern states — would vote against it. ${ }^{1102}$ She speculated that a significant number of the delegations that favoured the establishment of a Jewish state did so "in the hope that partition may prove to be a definitive solution of the Palestine people." And yet, she believed the Committee had

no clear idea of how to dispose of the Arab contention that partition would constitute a violation of the Charter, no conviction that the United Nations will be able to control the situation which will develop in Palestine when the British withdraw and no clear plan for the recruitment, equipment and training of an international security force or the maintenance of order within the security force itself. ${ }^{1103}$

MacCallum feared that time was running out for the Arabs. The Arab policy of abstaining and issuing threats of war had failed miserably to alter the momentum for partition. She knew that, with the American draft resolution at hand, the question of Palestine's fate would be shortly decided. She believed that she needed to act quickly if she was to convince Pearson that support for partition was not only politically hazardous, but that it was in clear breach of the United Nations Charter. On October 17, MacCallum sent a note to the under-secretary describing the assumptions upon which he and the Canadian delegation had based their support for partition. Foremost in her mind was Pearson's and Riddell's belief that the establishment of a Jewish State in Palestine would provide security for the war-weary Jewish people. Reiterating an earlier argument, she contended that a Jewish State, surrounded by a sea of angry Arabs, would not achieve its intended goal of providing the Jewish people a refuge from persecution. On the contrary, insisted MacCallum, it would intensify the hostility of the Arabs and unify Arabs and

\footnotetext{
1102 Elizabeth MacCallum, "Memorandum for Escott Reid," October 18, 1947, External Affairs Records, LAC, RG 25, Vol. 1057, File: 2-4-0, p. 1.

${ }^{1103}$ Ibid, pp. 1-2.
} 
Moslems in a common cause: the destruction of the Jewish State. Canada's support for partition would also damage its moral position in the Arab world, and have long lasting consequences for Canadian-Arab relations. ${ }^{1104}$

MacCallum's comments reflected her rejection of the UNSCOP process and its conclusions. She queried why Canada had decided to disregard so freely the warnings of the British, who had been in Palestine and managed its unrest for 27 years, and of the British Royal Commissions that had rejected partition as an impracticable measure. This misgiving was shared by Mackenzie King in early 1948:

I took strongly the position that the British had been a much longer time in their consideration of foreign policy than the Americans. That they were much wiser in regard to European affairs than the Americans, especially the Middle East, and the peoples there. I said if they were refraining from deciding as between the Jews and the Arabs, it unquestionably was for the strongest reasons of policy - reasons which would undoubtedly affect the whole future of the British Commonwealth and possibly of the world. . . 1105

Why too had Pearson and Canadian officials embraced a five-week assessment made by the ill-prepared and ill-qualified representatives of UNSCOP? MacCallum was convinced that the calculus for Canada's support for the majority plan was, in part, determined by the decision of the United States and the Soviet Union to support partition and the creation of a Jewish State. MacCallum believed it was a mistake for Canada to follow the U.S. and the U.S.S.R. because their motivations were not predicated on a desire to settle the Arab-Jewish conflict, but on the advancement of their own strategic

\footnotetext{
${ }^{1104}$ Elizabeth MacCallum, "Note for Mr. Pearson," October 17, 1947, External Affairs Records, LAC, RG 25, Vol. 3694, File: 5495-CD-2-40C, p. 1.

${ }^{1105}$ King Diary, March 23, 1948, p. 2.
} 
and political interests in the region. MacCallum considered the U. S. sponsorship of partition largely to have been driven by a desire to expand their own strategic and commercial influence in the region at the expense of the British. The Soviet Union's support for the majority report, in her view, was motivated by a deep desire to push the British out of the Middle East and create a threshold upon which they could expand their influence and power into the Mediterranean region. ${ }^{1106}$

MacCallum dispelled the assumption that the Arabs would ultimately accept partition and the new Jewish State. She held that this assumption ran contrary to the last 30 years of Palestinian history, during which Arab resistance to a Jewish National Home had remained constant. She warned Pearson that it was unlikely that Arab opposition to the Jewish presence would melt away as Mayrand and others in the Canadian delegation had predicted. On the contrary, opposition would become more active and violent. MacCallum concluded that a United Nations settlement, based upon partition, would not have the desired effect of ending the violence in Palestine, but would surely increase the instability in the Middle East. ${ }^{107}$ Neither the Canadian government's nor Pearson's attitude to the partition of Palestine was altered by her memorandum. ${ }^{1108}$

On October 21st, the Ad Hoc Committee began discussing procedures for going forward. The Soviet Union, with the support of the American and Canadian delegations,

\footnotetext{
1106 Hillmer, "Canada's Policy on the Partition of Palestine, 1947," p. 101.

${ }^{1107}$ MacCallum, "Note for Mr. Pearson," p. 2.

${ }^{1108}$ Hillmer, “Canada's Policy on the Partition of Palestine,” p. 111.
} 
called immediately for a vote on the principle of partition. ${ }^{109}$ The motion was defeated. As MacCallum had suspected, many of the member states were not prepared to support partition. ${ }^{1110}$ With no majority support in sight for either the majority or minority plans, the Ad Hoc Committee decided to appoint two sub-committees, as Canada had proposed, to examine the partition issue. The first sub-committee "was instructed to draw up a detailed plan for the future government of Palestine in accordance with the unanimous recommendations and the majority plan of UNSCOP." It was also to "consider methods of implementation and to plan for the administration of Palestine during the transitional period." 1111 The second sub-committee was to draw up in detail a plan for a unitary state. Delegations were placed on Sub-Committee I or II, depending on which plan they supported. As a result, there was a lack of balance in the sub-Committees' deliberations.

MacCallum focused her attention on the legal basis for partition. More precisely, she questioned the General Assembly's authority to impose a settlement. In an October 18, 1947 memorandum to Escott Reid, MacCallum echoed many of the concerns of departmental lawyer Max Wershof, who questioned whether the Ad Hoc Committee or its sub-Committees could disregard the Arabs' legal rights under the Charter's provisions. ${ }^{1112}$ As far as she was concerned, neither the Ad Hoc Committee nor the General Assembly had the legal right to impose partition without first gaining the consent

\footnotetext{
1109 Elizabeth MacCallum, "Memorandum for Escott Reid," October 25, 1947, External Affairs Records, LAC, RG 25, Vol. 1057, File: 2-4-0, p. 1.

1110 Ibid.

1111 Ibid.

1112 Max Wershof, "Legal Aspects of Actions on Palestine by the United Nation,” October 17, 1947, External Affairs Records, LAC, RG 25, Vol. 3694, File: 5475-CD-2-40, p. 1.
} 
of the Palestinian population and those countries directly affected. The Committee's and Assembly's deliberations had failed to address the issue. Moreover, they had no clear idea of how "to dispose of the Arab contention that partition would constitute a violation of the Charter." Nor did MacCallum think that the United Nations would be able to control the situation after the British withdrew. No clear plan had been proposed for the recruitment, equipment and training of an international security force, nor had a plan for the maintenance of order been agreed upon by the permanent members of the Security Council. ${ }^{1113}$

MacCallum expanded on these concerns in her October 25th memorandum, "Draft Memorandum: A Plan for Partition." 1114 Her central thesis was that the majority plan violated international law and numerous articles of the Charter. She argued that the General Assembly had no legal authority "to divide the country against the wishes of the majority of the population and to turn over $65 \%$ of the territory to the Jews, who now own only $6 \%$ of the land." This violated Article 1(2) of the Charter, which stated that the United Nations” purpose, among others, was to “develop friendly relations among nations based on respect for the principle of equal rights and self-determination of peoples, and to take other appropriate measures to strengthen universal peace.”1115 Partition violated these legal guarantees. It contravened the provisions guaranteeing the Arabs' "equal

\footnotetext{
1113 Elizabeth MacCallum, "Memorandum for Escott Reid," October 17, 1947, External Affairs Records, LAC, RG 25, Vol. 1049: no file number, p. 2.

1114 Elizabeth MacCallum, "Draft Memorandum: A Plan for Partition," October 25, 1947, External Affairs Records, LAC, RG 25, Vol. 1057, File: 2-4-0, p. 1. MacCallum stated that the partition plan was in violation of Articles 1, 10, 11, 33, 34, 35, 36, 37, 38, 52, 70, and 80 of the United Nations Charter.

1115 United Nations, Charter of the United Nations and Statute of the International Court of Justice, [Reprint] (New York: United Nations Department of Public Information, 2001), p. 5.
} 
rights and self-determination," and undermined "universal peace," the very bedrock of the United Nations Charter. The partition plan would be seen by the Arabs as a provocation for war. Also disconcerting to MacCallum was that the Ad Hoc Committee's determination to establish an international security force to impose partition and prevent the majority population from defending their lands violated Article 51 of the Charter, which stated that "nothing in the present Charter shall impair the inherent right of individual or collective defence if an armed attack occurs against a member of the United Nations . .."1116 In other words, the Charter could not impose minority rights upon a majority population through force of arms. Russell Hopkins, another of the External Affairs lawyers, concurred with MacCallum's assessments. ${ }^{1117}$

In an effort to find a way out of the inconvenient legalities, Riddell instructed MacCallum to study the Trusteeship provisions in the Charter and ascertain whether there was a means by which the General Assembly could effectively facilitate the implementation and enforcement of the partition plan. Simply put, Riddell wanted MacCallum to devise a scheme for circumventing Article 79 of the Charter, which stated that: "The terms of Trusteeship for each territory to be placed under the Trusteeship system ... shall be agreed upon by the states directly concerned. ..."1118 He also directed her to determine whether there were any legal impediments that prevented the General Assembly from forcefully implementing partition and imposing a temporary Trusteeship

\footnotetext{
${ }^{1116}$ Ibid, p. 32.

1117 Russell Hopkins, "Draft Statement on Palestine," October 25, 1947, External Affairs Records, LAC, RG 25, Vol. 1057, File: 2-4-0, p. 2.

1118 United Nations Organization, "Chapter 12: International Trusteeship System," The Charter of the United Nations, p.197.
} 
over Palestine while imposed implementation was taking place. This confirmed the extent to which Pearson and Riddell were prepared to go in partitioning Palestine. To fulfill Riddell's request would require MacCallum to alter her interpretative lens from a legal to a political viewpoint.

MacCallum laid out two possible courses of action for Riddell. First, the Assembly could modify or amend the existing British Mandate to accommodate the partition of Palestine. Second, the Assembly could establish a new Trusteeship for administering Palestine during the transitional period. In addressing the first option, MacCallum affirmed that, according to United Nations Charter Article 80(1), any attempt to modify or amend the "manner of the rights" within the Mandate agreement without the consent of the original mandatory power was prohibited. Surely Creech-Jones' statement of October 13th made it clear that Britain would reject any efforts to amend the mandatory agreement in order to facilitate the partitioning of Palestine, awarding the Zionists a disproportionate share of Palestine's territories and resources. MacCallum concluded that the only way to proceed was to terminate the existing Mandate and establish a new Trusteeship. ${ }^{119}$ With respect to a new Trusteeship, MacCallum advised Riddell that the General Assembly would be additionally bound by the wide-ranging provisions of Article 73, until such time as independence was achieved by the peoples of

1119 Ibid. Also see: Article 80 (1), United Nations, Charter of the United Nations and Statute of the International Court of Justice, [Reprint] (New York: United Nations Department of Public Information, 2001), pp. 50-51. 
Palestine. ${ }^{1120}$ According to Article 73, stated MacCallum, the United Nations must "recognize the principle that the interests of the inhabitants of these territories are paramount. . .."1121 The United Nations would be compelled under the Charter "to develop self-government, to take due account of the political aspirations of the peoples of Palestine and to assist them in the progressive development of their free political institutions." ${ }^{1122}$ Further, under Article 73(c), the Assembly could not take any action that would further undermine the peace and security of the region. ${ }^{1123}$

MacCallum underlined the irreconcilability of Article 73 and 79 with respect to the partition plan. How could a Trusteeship, which intended to lay the framework for and implement partition, also recognize Arab Palestinian interests, promote their national well-being, respect their culture, advance their social development, and encourage their political aspirations? ${ }^{1124}$ MacCallum also recognized that, if the partition plan was imposed by force of arms, it would gut Article 79 of its democratic principles and open the floodgates for further violations of the United Nations Charter. Once accepted, it would be undoubtedly employed by the Soviets to seize and justify control of weaker states.

${ }^{1120}$ Elizabeth MacCallum, "Draft Memorandum: A Plan for Partition for Submission to Sub-Committee I of the Ad Hoc Committee on the Palestine Question," October 25, 1947, External Affairs Records, LAC, RG25, Vol. 1057, File: 2-4-0, p. 2.

${ }^{1121}$ Ibid.

1122 Ibid.

${ }^{1123}$ Article 73, Charter of the United Nations and Statute of the International Court of Justice, p. 46. ${ }^{1124}$ Ibid. 
To get around this impasse, MacCallum proposed that "once the Ad Hoc Committee had drafted the terms of a Trusteeship agreement, in consultation with the United Kingdom delegation, and after the principle of partition was accepted by a twothirds vote in the Assembly, the draft could be put to a vote." ${ }^{1125}$ If the vote failed to achieve the required majority, it could be referred to the Security Council. However, both courses of action required the support of all the parties involved. With regard to Arab opposition, MacCallum suggested that the members of the Assembly needed to demonstrate to the Arab World their willingness to share the burden of the refugee crisis. MacCallum suggested that the temporary Palestinian Trusteeship agreement should include the acceptance of UNSCOP's sixth unanimous recommendation, calling on each member of the United Nations to join with other nations in the development of an overall immigration plan that would reduce Palestine's burden in taking in non-repatriable persons.

As the Ad Hoc Committee's Working Group 1 began its final debate on the Majority Plan in late October 1947, a subdued mood hung over the discussions. It was apparent to Pearson and the Canadian delegation that the U.S. and the U.S.S.R. were deeply divided over the date that the British Mandate should be terminated, how partition should be implemented, and who should, at least in the short-term, administer and enforce the implementation of partition after the British relinquished the Mandate. Britain remained steadfastly determined not to take a part in implementing the majority plan, or

\footnotetext{
${ }^{1125}$ Hillmer, “Canadian Policy on the Partition of Palestine, 1947," p. 122.
} 
in enforcing it. In fact, they were determined to withdraw their forces from Palestine as soon as physically possible.

On November 4th, after listening to the U. S. and U.S.S.R. delegations present their views during the Working Group deliberations, Pearson took his turn, reading from a prepared statement outlining the Canadian position. It was evident that Pearson was no longer willing to stand by as the Great Powers stumbled their way through the Palestine question. He was resolved to bring the Great Powers together behind UNSCOP's Majority Plan. His statement was pragmatic and clear-minded. Pearson explained that, if the Majority Plan was to be successfully undertaken, it had to be implemented in a practical manner; it would have to conform, at least in spirit, to the United Nations Charter; and Great Power co-operation would be essential. ${ }^{1126}$ Pearson's approach broke the American-Soviet stalemate on implementation and enforcement of the Majority Plan. After several weeks of Great Power differences, Pearson successfully got the Great Powers to accept his compromise scheme, eventually leading the Working Group to vote in favour of submitting the Majority Plan to the Ad Hoc Committee and General Assembly for deliberation and ratification.

On November 29, after days of intense debate, lobbying, and political maneuverings, the General Assembly put the Majority Plan to a vote. When the tally was complete, 33 members voted in favour of the Plan, 13 voted against its approval, and 11 members of the Assembly abstained. Partition had achieved a two-thirds majority,

1126 Canadian Delegation, "Text of Statement by Mr. L .B. Pearson, representative of Canada, in SubCommittee 1 of the Ad Hoc Committee on the Palestinian question," November 4, 1947, External Affairs Records, LAC, RG 25, Vol. 1057, File: 2-4-0, p. 1. 
ensuring the passing of resolution 181: the creation of two independent states in Palestine. Following the vote, the Arab delegations stormed out of the Assembly's chambers in unison, declaring that the U.N. resolution was invalid and any attempt to implement it would lead to war. It was inconceivable to the Arabs that the United Nations would award the Jews any part of Palestine. How 37 percent of the population could be given 55 percent of the area was unimaginable to the Arabs and to MacCallum. The partition of Palestine was one of the greatest triumphs of Pearson's diplomatic career, but for MacCallum it was a tragedy.

\section{Conclusion}

In 1947, after serving for five years as a wartime clerk at the Department of External Affairs, MacCallum had been accepted as one of the department's own. She had gained the respect of her superiors and had proven herself valuable to the department. She was among the first women in the department to be selected as a foreign service officer, and she was appointed the officer responsible for Middle East affairs. Then, she was appointed to the Canadian delegation for the United Nations' special session on Palestine.

MacCallum's career was inextricably linked to the United Nations' decision to take up the Palestine crisis. After more than 30 years of trying to resolve Arab-Jewish differences, Britain's new Labour government referred the Palestine problem to the General Assembly for consideration. Unlike many of her colleagues in the East Block, MacCallum was neither annoyed nor surprised by Britain's decision. She was, however, troubled. Three facts, in her judgment, were unassailable. First, Canada could no longer 
avoid taking a position on Palestine and the Jewish refugee crisis. Both had become international problems. Second, the United Nations' credibility and future depended on the outcome of the Palestinian settlement. Lastly, and deeply concerning to MacCallum, was the role of the Great Powers. They would be either peacemakers or troublemakers. Given the Anglo-American tensions over Palestine and the American-Soviet strains in Turkey, Iran, and Greece, a peaceful and mutually agreed upon solution would not be easy to find.

Reluctantly the prime minister agreed to send a small delegation to the special meeting of the Second Session of the General Assembly. He ordered it to keep a low profile and not commit Canada to any activity if possible. However, pressed by the Americans, Canada agreed to serve on the United Nations Special Committee on Palestine (UNSCOP). Supreme Court Justice Ivan Rand was chosen as Canada's representative to UNSCOP. MacCallum had misgivings about Rand; he lacked the experience and the expertise for such an important mission. More importantly, he knew nothing of the region or its politics. While she tried her best to prepare him for his duties, she feared that he had already made up his mind to side with the Zionist case. She also worried that UNSCOP's. members were ill-suited for the duties ahead, and for separating fact from propaganda.

MacCallum's fears were well founded. On September 1, 1947, the Special Committee's report was released. Its first part recommended the termination of the Mandate and the establishment of an independent state of Palestine after a two-year transition period. The second part presented two plans for Palestine's independence: the 
Majority Plan and the Minority Plan. The first plan called for the partition, or division, of Palestine into two states, one Jewish and the other Arab. The Minority Plan called for a binational state comprised of two autonomous administered by a central government. With the release of the UNSCOP report, Palestine erupted in jubilation and anger; Zionists welcomed the proposal, while the Arabs promised bloodshed if it was realized.

Lester B. Pearson, the under-secretary of state for external affairs, saw a Jewish state as inevitable. With little regard for the rights of the Arabs, he advocated support for the Majority Plan. MacCallum, on the other hand, thought that a peaceful solution to the problem would not be found by imposing a United Nations decision. If a solution were forcefully imposed on either party, warned MacCallum, far greater violence would be unleashed on Palestine, and quite possibly, beyond. She insisted that the two parties needed time to negotiate a settlement that was satisfactory to all. She continued to challenge Pearson's position throughout the session by suggesting that it violated numerous provisions of the U. N. Charter. In particular, she questioned how the implementation and enforcement of partition could occur without violating the Charter. And how would the partition of Palestine ensure the security for the new Jewish state? Yet Pearson had prevailed, leading the United Nations and the Great Powers where MacCallum was convinced that they should not go. 


\section{Conclusion}

Within hours of the General Assembly's decision on UNSCOP's Majority Plan, fighting erupted between the Palestinian Arabs and the Jewish Yishuv forces. The conflict rapidly escalated when Britain relinquished its Mandate in 1947. "The Jewish authorities," recalled MacCallum, "immediately proclaimed the establishment of the 'State of Israel' and in a cablegram on May 14th to the Secretary-General applied for membership of 'Israel' in the United Nations." For MacCallum, the British surrender of the Mandate to the United Nations, the Arab unwillingness to accept partition, and the Jewish proclamation of independence, had combined to precipitate an all-out war between the Arab World and the State of Israel. ${ }^{1127}$ With the complete withdrawal of British troops, the Arab nations were no longer prevented from intervening in the conflict. Lebanon and Syria quickly engaged the Jewish forces in the north; Iraq and Transjordan attacked in the East; Egypt, supported by contingents from the Sudan, engaged Jewish forces in the south; and Palestinians and volunteers from Arab countries attacked Jewish cities in the interior. ${ }^{128}$

The Israeli "war of independence," or the Arab's al-Nakba (catastrophe or humiliation), became the most traumatic event in modern Arab-Jewish history. While the war lasted only 20 months, its repercussions were long-standing and extensive. The

1127 Elizabeth MacCallum, "The Palestine Question," September 15, 1948, External Affairs Records, Library and Archives Canada (LAC), RG 25, Vol. 5745, File: 47-B (S), Part 6, p. 3.

1128 Benny Morris, Righteous Victims: A History of the Zionist-Arab Conflict, 1881-1999 (New York: Alfred A. Knopf, 1999), p.217. "The Arab forces in Palestine consisted of not more than 28,000 some 5,500 Egyptians, 6,000-9,000 Arab Legionnaires [of Transjordan], 6,000 from Syria, 4,500 from Iraq, a handful from Lebanon. . . The combined Arab armies had some 75 combat aircraft, 40 tanks, 500 armoured vehicles, 140 field guns, and 220 antiaircraft and antitank guns.” 
fighting resulted in the death of 6,373 Jewish civilians and soldiers, or one percent of Israel's population of 650,000 . Nevertheless, Israel had succeeded in increasing its size by capturing 60 percent of the land formally allotted to Arabs by the General Assembly's Majority Plan. ${ }^{1129}$ The cost of war for the Arabs was far greater. By early 1949, the year that an Arab-Israeli truce was signed, more than 750,000 Palestinian Arabs had left or had been driven from their homes and ancestral lands, forcing them to seek refuge in the neighbouring Arab states. Israeli historian Simha Flapan described the Arab Palestinians as "a nation of refugees, deprived of their homeland and any real hope for sovereignty, subjected to oppression and discrimination by Jews and Arabs alike." ${ }^{1130}$ It was burned into the psyches of both communities. The war triggered a regional arms race that involved the United States and the Soviet Union. Both Arabs and Jews made endless demands on their patrons for more powerful and lethal weapons, expanding the conflict's participants and scale of suffering. This ensured an unending cycle of terror and reprisal, and a tragic legacy of mutual fears, suspicions, prejudices, and recriminations.

This dissertation has examined Elizabeth MacCallum's ideas about Palestine and the Middle East, by studying the foundation, development, and substance of her views about the region and in particular about Palestine during the period 1925-1947. It had also examined the manner in which MacCallum applied these ideas as a writer, researcher, and as a member of the Department of External Affairs. In particular, this study has examined how she used her extensive knowledge of Arab history and Middle

\footnotetext{
${ }^{1129}$ Kenneth Cragg, Palestine: The Prize and Prince for Zion (London: Cassell \& Co., 1997), pp. $57,116$. ${ }^{1130}$ Simha Flapan, The Birth of Israel: Myths and Realities (New York: Pantheon Books, 1987), p. 4.
} 
East politics to encourage an understanding of the Arab point view regarding the ongoing discussions regarding the Palestine Mandate.

As noted in the introduction to this study, having grown up in Marash, Turkey, an important missionary capital in the Ottoman Empire, MacCallum was alive to the Arab people's history, their politics, their anger and grievances, and the splendour of their culture and religion. She also came to understand their religious and nationalist passions. She witnessed the Turkish and Moslem bitterness towards Christian Armenians, who demanded an independent state within the Ottoman Empire. Consequently, the MacCallum compound, where her father's seminary was located, became a sanctuary not only for safeguarding the MacCallum children, but also providing protection for her father's young Armenian pupils. The MacCallum children themselves experienced feelings of vulnerability and isolation.

Elizabeth MacCallum's sense of isolation did not end with her departure from Turkey; she sensed a clear difference between her and her Canadian classmates. They seemed to know virtually nothing of the world outside of Canada. She missed the benefits of living a bilingual life. "It was not just a matter of language, vocabulary," said MacCallum, "but a sort of dual and enriched view of life."1131 Her thoughts often turned back to her to her life in the Middle East and the Arab World.

MacCallum's academic years at Queen's and Columbia Universities proved equally frustrating. As missionaries, her parents were never financially safe. They could

\footnotetext{
${ }^{1131}$ Elizabeth MacCallum Papers.
} 
not finance MacCallum's university education. Frequently fighting poverty, she was forced to set aside her studies and seek employment on numerous occasions. Each interruption disrupted her academic progress, leaving her with the feeling that she was starting over. Her financial hardship also had a significant effect on her health. While working as a teacher in Northern Alberta in 1919, for example, she suffered damage to her hearing, which in time left her virtually deaf. This condition further isolated MacCallum from activities and friends.

In 1925, after only two years of graduate school, MacCallum joined the Foreign Policy Association as a researcher-writer on Middle East affairs. The job solved many of her financial problems and enabled her to pursue her study of the Middle East. In just a decade MacCallum wrote thirty articles and three books on Syria, Lebanon, Iraq, Transjordan, Egypt, Palestine, Turkey, Albania, and the Balkans. The central narrative and the crucible of her analysis was that the rights of the Arab World had been violated by the Western imperial powers and compromised by their regional ambitions. Her work recounted the devastating effects that Western policies had on the liberated territories of the former Ottoman Empire. In particular, she described how Britain's and France's policies created Arab mistrust of the Western powers and their institutions, especially the League of Nations and its Mandates System. She contended that the League, through the Mandates System, had legitimized the Western powers' annexation of Arab territories and their exploitation of Arab natural resources.

For MacCallum, Britain's Palestine Mandate exemplified the Western powers' abuse of Arab rights. The Mandate was a self-serving policy, the British pledged to the 
Arabs that in time Palestine would be turned into an Arab sovereign state; however, implicit in the Mandate was a promise to the Zionists the establishment of a Jewish National Home in Palestine. MacCallum's writings on Palestine repeatedly warned of the dangers of Britain's self-seeking impulses. Britain's contradictory policy, she insisted, had led to the entrenchment of two opposing and incompatible nationalisms. She argued that the Jewish community in Palestine would in time demand a greater portion of Palestine, and, ultimately, that they would demand that all of Palestine be transformed into a Jewish state, turning the Arab majority into a minority in their own land. Time and time again, she warned that Britain's Mandate policy would lead to unending conflict, the radicalizing of both Arab and Zionist nationalisms, the involvement of the Great Powers, and inevitably, a war in Palestine.

After six years of writing for the Foreign Policy Association, and plagued by progressively deteriorating hearing, MacCallum resigned from the Association and purchased a small two-acre farm in Uxbridge, Ontario. She found comfort in her seclusion. During the next four years, she wrote on the logic of the West's treatment of the Arab World. No longer constrained by the Association's editorial guidelines, MacCallum wrote disparagingly about the League's irresponsible actions regarding the Mandates System and the treatment of the Arabs; she reproached the Western powers for their imperial and predatory policies towards the Middle East, and she warned of restless and growing Arab nationalism emanating from the region. Combined, these essays reflected MacCallum's growing frustration with the international community's treatment 
of the Arab World, and her strong convictions that the Western powers had to redress Arab grievances.

In 1942, MacCallum joined the Department of External Affairs. Like so many other women, she wanted to make a contribution to Canada's war effort. She entered not as a Middle East expert, but as a clerk, there to fill the seat left vacant by a man serving in the military. Over the next three years, MacCallum was slowly given the opportunity to demonstrate her knowledge of Middle East politics. On several occasions, in response to Zionist lobbying, she was directed by the department to provide background papers and memoranda on Canada's obligations under the Balfour Declaration of 1917, the 1922 British Mandate in Palestine, and the 1939 British White Paper. For the first time the department had a Middle East specialist. Using her special knowledge of Arab history, MacCallum could act as a counter-weight to offset the Zionist lobbying efforts. Her writings cautioned the government about involving itself in the Palestine question, mindful of Canada's domestic priorities and the prime minister's sensibilities. Her work was recognized and she was appointed to the Canadian delegation to the United Nations founding conference in San Francisco.

While the San Francisco conference turned out to be a bittersweet experience for MacCallum — providing no opportunity to contribute to the development of policy — it afforded her experiences, insights, and on occasion, a chance to witness firsthand the efforts of Arab states and of Jewish Agency representatives to bring the question of Palestine to the floor of the United Nations. It became clear to her that the Americans and 
British were deeply divided over the fate of Palestine's Mandate, leading the Great Powers deliberately to avoid the subject.

By 1946, it became apparent to MacCallum that Palestine had reached a boiling point. Arab and Jewish positions on Palestine were unmoving, as were the American and British positions. After numerous British efforts to reach an agreement on the fate of the Mandate, all talks broke off. The stalemate was exacerbated by America's determination to take a role in the crisis, which only prompted greater anxiety and violence in Palestine. In an effort to alert External Affairs to the dangers associated with the unstable politics of Palestine, MacCallum wrote a series of memoranda warning the department about the risks that Palestine posed to the Canadian government and state of international affairs. She predicted that an escalation of fighting would occur in Palestine and beyond. She believed the Truman Administration had damaged Anglo-American relations by demanding the immediate entry of 100,000 Jewish refugees into Palestine. This, MacCallum knew, would only alienate the Arab World, and cause increasing domestic unrest among the Arab and Jewish communities in Canada.

By early April 1947, it could not be claimed that Palestine was a British problem. London had asked that the Palestine question be placed on the agenda of the General Assembly's next regular annual session in order that it could study and make recommendations on the future of the Mandate. Realizing that his government had little choice, Mackenzie King reluctantly agreed to create a small delegation to attend a special General Assembly session on Palestine. Led by Lester Pearson, under-secretary of state for external affairs, the small delegation included Elizabeth MacCallum. Her appointment 
provided her the opportunity to play a role, as a technical advisor, in developing Canada's approach to the Arab-Jewish problem. MacCallum was wholly committed to promoting a solution that was mutually agreed upon. No solution, in her judgement, could be imposed.

In committee after committee — UNSCOP, the Ad Hoc Committee, Working Group I - Canadian representatives supported partition and the creation of a Jewish state. Each time, MacCallum discouraged the delegation's support for partition. She challenged the views of R. G. Riddell, George Ignatieff, and Lester B. Pearson, who insisted that partition was the only solution to the problem. She cautioned against drawing premature conclusions about its practicality. She proposed instead a more moderate approach, one based on a negotiated settlement between the Arabs and Jews, rather than accepting the imposition of partition. MacCallum ardently believed that Pearson's advocacy of the partition policy was based on false premises and assumptions. She contended that such a course of action violated the U. N. Charter of rights, the principle of national self-determination, and the Canadian government's commitment to maintaining international peace and security. She also insisted that the Arabs would never accept partition when other solutions existed. She also refuted Pearson's belief that Palestine would become a safe haven for the world's Jewry. She restated to him her longheld belief that the Arabs would go to war before they would accept a Zionist state in the heart of the Arab World.

In the end, Pearson's diplomacy was persuasive. The Canadian delegation supported the under-secretary's sponsorship of partition, against the reproaches of 
MacCallum. On November 29, 1947, after much diplomatic maneuverings, the General Assembly voted in favour of partition, and in doing so, ended the British Mandate in Palestine. The outcome was a tragic one for MacCallum. In the days and weeks that followed, her concerns were vindicated when war broke out, and all informal dialogue between the Arabs and the Jews abruptly ended. The United Nations had suffered a monumental setback in its work of resolving international disputes.

While modest in scale, the historiography of Canada's role in the Palestine conflict has come to very different assessments and conclusions regarding MacCallum's contribution to Canada's early Middle East policy. For many scholars, MacCallum played only a minor role in shaping Canada's Middle East policies. For others, she was the driving force in defining Canada's approach to the region. Middle East historian Eliezer Tauber believed MacCallum was a marginal actor who played an insignificant part in the creation of Canada's Middle East policy. He accused her of distorting or deliberately exaggerating evidence in order to advance her own views and aims and to discredit the lobbying efforts of Zionists in Canada and prevent the establishment of the Jewish state. At the opposite end of the interpretive spectrum, Israeli historian Zachariah Kay maintained that MacCallum had considerable influence on government thinking. In between these two poles, historians Anne Trowell Hillmer and David Jay Bercuson took a more limited interpretation of MacCallum's role. Bercuson thought that her influence was limited to early on, and that it had waned by the crucial 1946-1947 period. While 
acknowledging her expertise, Hillmer did not find that MacCallum's knowledge translated into genuine influence. ${ }^{1132}$

This dissertation has attempted to place MacCallum somewhere in the middle of this academic dispute. The arguments all have a dash of truth in their analysis. Tauber was correct in his assertion that MacCallum undermined the lobbying efforts of the Jewish lobby. Her earlier duties with External Affairs required her to assess the arguments put forth by the Zionists, and evaluate the veracity of their assessments. Few in the department had the knowledge to take on such duties prior to MacCallum's arrival. Kay was also partially correct in suggesting that documents concerning the Middle East all went through her hands. MacCallum, after all, was the clerk, and later on, the officer responsible for Middle East affairs. It was her responsibility to examine each document and bring it to the attention of her superiors. David Bercuson is correct in suggesting that between 1942-1947 MacCallum attempted to create an Arab perspective by offering the department a unique and scholarly approach to the question of Palestine. She therefore attempted to familiarize the department with Arab history, culture, and politics and to ensure that both Arab and Jewish points of views would be equally well understood. ${ }^{1133}$

\footnotetext{
1132 Anne Trowell Hillmer, "Canadian Policy on the Partition of Palestine, 1947" pp. 17-18. Also see Hillmer, "Here I Am in the Middle': Lester B. Person and the Origins of Canada's Diplomatic Involvement in the Middle East," in David Taras and David H. Goldberg (eds.), The Domestic Battleground: Canada and the Arab-Israeli Conflict (Montreal \& Kingston: McGill-Queen's University Press, 1989).

1133 John Hilliker and Donald Barry. Canada's Department of External Affairs: Vol. 2, Coming of Age, 1946-1968 (Montreal and Kingston: McGill-Queens University Press, 1995), p. 114.
} 
The real nature of MacCallum's influence cannot be measured in shifts of policy or thinking, or in superiors abandoning positions firmly held. Her influence lay in bringing expertise to bear on a complex problem, and in arguing that there were two sides to every story. She asked an outsider's questions about why the Great Powers could not think of anything but their own narrow interests, and why official Canada could not think beyond the straitjacket of their alliances and the Great Powers that preoccupied Canadian policy. She was an insider now, but she continued to ask, and wait for answers to the questions that went to the heart of a just settlement to the Middle East's problems. 


\section{Bibliography}

\section{ARCHIVAL SOURCES}

\section{LibraRy AND ARCHIVES CANADA}

Canadian Palestine Committee Papers

Civil Service Commission of Canada Papers

Department of External Affairs Records

George Ignatieff Papers

Louis S. St. Laurent Papers

Office of the Privy Council of Canada Papers

William Lyon Mackenzie King Papers (includes diary)

Zionist Organization of Canada Papers

\section{QUEEN's UnIVERSITY AluMNi RECORDS}

Alumni Records

Oral History Project

\section{Provincial Archives of Manitoba}

Jewish Historical Society of Western Canada Papers

\section{The National ARChives of the Great Britain}

Cabinet Office Records

Colonial Office Records

Foreign Office Records 


\section{In Private Hands}

Anne Trowell Hillmer Papers

Judith Nicholas Papers

Elizabeth Pauline MacCallum Papers

Michael Shenstone Papers

\section{PRINTED PRIMARY SOURCES:}

\section{Writings of Elizabeth MacCallum}

\section{(a) Books}

MacCallum, Elizabeth Pauline, The Nationalist Crusade in Syria (New York: Foreign Policy Association, 1928).

Twenty Years of Persian Opium (1908-1928): A Study (New York: Foreign Policy Association, 1928). 1935).

Rivalries in Ethiopia (Boston: World Peace Organization,

\section{(b) Articles}

MacCallum, Elizabeth Pauline. "Social Statistics," Social Welfare, Vol. 6, No. 7 (July, 1924), pp. 202-203.

"The Turco-Iraq Boundary Dispute," Editorial Information Service of the Foreign Policy Association, Vol. 1, No. 3 (Series 1925-26, November 5, 1925), pp. 1-8.

"British Interests in Mesopotamia," Information Service of the Foreign Policy Association, Vol. 1, No. 4 (Series 1925-26, November 17, 1925), pp. 1-8.

"The French Mandate in Syria," Editorial Information Service, No. 5, Series 1925-26 (December 5, 1925), pp. 1-8.

"American Oil Interests in Mesopotamia," Information Service of the Foreign Policy Association, Vol. 2, No. 6 (Series 1925-26, May 22, 1926), pp. 68-78.

"The International Problem of Tangier," Information Service of the Foreign Policy Association, Vol. 2, No. 15 (September 29, 1926), pp. 169-180. 
"American Missionary and Philanthropic Enterprises in Turkey," Information Service of the Foreign Policy Association, Vol. 2, No. 22 (January 5, 1927), pp. 254-272.

"Survey of Political Trends in the Near East, 1926," Information Service of the Foreign Policy Association, Vol. 2, No. 26 (March 2, 1927), pp. 318-333.

"Functions of the Permanent Mandates Commission," Information Service of the Foreign Policy Association, Vol. 3, No. 4, Series 1927-28 (April 27, 1927), pp. 45-60.

"Egyptian Nationalism and British Imperial Interests," Information Service of the Foreign Policy Association, Vol. 3, No. 11 (August 3, 1927), pp. 153-168.

"Political and Economic Trends in the Near East, 1927,"

Information Service of the Foreign Policy Association, Vol. 3, No. 26 (March 2, 1928), pp. 427-441.

"The Near East in 1928," Information Service of the

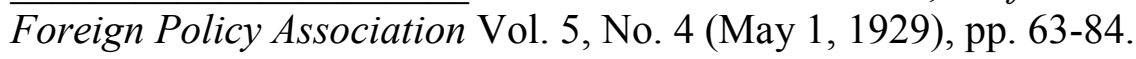

"Background of Unrest in Ancient Palestine," New York Times, September 1, 1929, p. XX4.

"The Palestine Conflict," Information Service of the

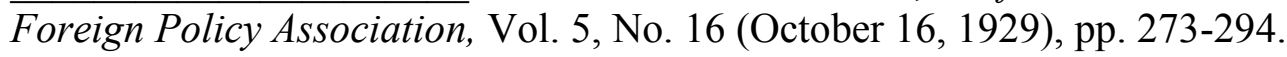

"The Near East Under the Mandates," The Moslem World, Vol. 19, No. 4 (October, 1929), pp. 331-337.

"Iraq and the British Treaties," Information Service of the

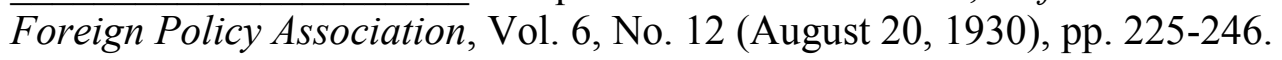
22 (January 7, 1931), pp. 403-420.

"Egypt: A Decade of Political Development," Vol. 6, No. 1933), pp. 1-7.

"Untitled," Kingston Whig-Standard (December 14, "Great Britain and the Race Problem in Palestine," Foreign Policy Reports, Vol. 10, No. 13 (August 29, 1934), pp. 158-168.

"The Arab Nationalist Movement," Foreign Policy Reports, Vol. 11, No. 5 (May 8, 1935), pp. 50-56.

pp. 1-8.

"Political Unrest in Transjordan," [Unpublished, n.d.],

"Minorities in Syria and Iraq: A Review of League Policy under the Mandate System," [Unpublished, n.d.], pp. 1-33.

“The Class A Mandates," [Unpublished, n.d.], pp. 1-18. 
pp. 1-31.

"The League and the Arab World," [Unpublished, n.d.],

\section{GOVERNMENT PUBLICATIONS}

\section{(a) Canada}

Canada. Documents on Canadian External Relations, Vol. 1: 1909-1918 (Ottawa: The Queen's Printer, 1967).

Canada. "Royal Commission on the Civil Service," Report of the Commissioners (Ottawa: The King's Printer, 1908).

Canada, Department of External Affairs, Report on the United Nations Conference on International Organization, Conference Series, No. 2 (Ottawa: The King's Printer, 1945).

Canada. Report of the Royal Commission on Administrative Classifications in the Public Service (Ottawa: The King's Printer, 1946).

Canada. "External Affairs Register: Biographical Notes on the Officers of the Department of External Affairs," 1962.

Canada. The Department of External Affairs and Biculturalism: Diplomatic Personnel (1945-1965) and Language Use (1964-1965), Vol. 3, Studies of the Royal Commission on Bilingualism and Biculturalism (Ottawa: Government of Canada, 1965).

Hillmer, Norman and Donald M. Page., eds. Documents on Canadian External Relations, Vol. 13: 1947 (Ottawa: Supply and Services Canada, 1993).

Hilliker, John F., ed. Documents on Canadian External Relations, Vol. 9: 1942-1943 (Ottawa: Supply and Services Canada, 1980).

Hilliker, John F., ed. Documents on Canadian External Relations, Vol. 11: 19441945, Part II (Ottawa: Supply and Services Canada, 1990).

MacKay, R. A., ed. Documents on Canadian External Relations, Vol. 2: The Paris Peace Conference of 1919 (Ottawa: The Queen's Printer, 1969).

Munro, John A., ed. Documents on Canadian External Relations, Vol. 6: 1936-1939 (Ottawa: Information Canada, 1972).

Page, Donald M., ed. Documents on Canadian External Relations, Vol. 12: 1946 (Ottawa: Supply and Services Canada, 1977).

\section{(b) Great Britain}

Great Britain. Palestine: Report on Immigration, Land Settlement and Development by Sir John Hope Simpson, Cmd. 3686 (London: His Majesty's Stationary Office, 1930).

Great Britain. Report of Palestine Royal Commission, [Peel Report], Cmd. 5474 (London: His Majesty’s Stationary Office, 1937). 
Great Britain. Report of Palestine Partition Commission, [Woodhead Report], Cmd. 5854 (London: His Majesty's Stationary Office, 1938).

Great Britain. Palestine: Statement by His Majesty's Government, Cmd. 5893 (London: His Majesty's Stationary Office, 1938).

Great Britain. The British White Paper on Palestine, Cmd. 6019 (London: His Majesty's Stationary Office, 1939).

Great Britain. British Colonies, Protectorates, Etc. (Local Legislatures) (London: His Majesty’s Stationary Office, 1939).

Great Britain. Proposals for the Reform of the Foreign Service, Cmd. 6420 (1943).

Great Britain. Report to the General Assembly by the United Nations Special Committee on Palestine (1947).

Great Britain. Report on the Proceedings of the Second Session of the General Assembly of the United Nations, Cmd. 7320 (1947).

Great Britain. "Women in Diplomacy: The FCO, 1782-1999," History Notes, Foreign \& Commonwealth Office (No. 6, May 1999).

\section{(c) United States of America}

Calkin, Homer. Women in the Department of State: Their Role in American Foreign Affairs (Washington, D. C.: Department of State Publication, 1978).

United States, Foreign Relations of the United States, 1922, Vol. 2 (Washington D. C.: Government Printing Office, 1938).

United States, Foreign Relations of the United States, Cairo and Tehran Conferences, 1943 (Washington D. C.: Government Printing Office, 1961).

United States, Foreign Relations of the United States, The Conferences at Washington and Quebec, 1943 (Washington D. C.: Government Printing Office, 1970).

United States, Foreign Relations of the United States, 1944, Vol. 1, General (Washington D. C.: Government Printing Office, 1966).

United States, Foreign Relations of the United States, 1945, Conferences at Malta and Yalta (Washington D. C.: Government Printing Office, 1955).

United States, Foreign Relations of the United States, 1945, Vol. 8, The Near East and Africa (Washington D. C.: Government Printing Office, 1969).

United States, Foreign Relations of the United States, 1946, Vol. 6, Eastern Europe, The Soviet Union (Washington D. C.: Government Printing Office, 1969).

United States, Foreign Relations of the United States, 1946, Vol. 7, The Near East and Africa (Washington D. C.: Government Printing Office, 1969). 
United States, Foreign Relations of the United States, 1947, Vol. 5, The Near East and Africa (Washington D. C.: Government Printing Office, 1971).

United States of America. Charter of the United Nations: Report to the President (Washington D. C.: Department of State, 1945).

\section{NON-GOVERNMENT DOCUMENTS}

League of Nations. The Covenant of the League of Nations, 1924.

League of Nations. The Mandate System: Origin-Principles-Application, 1945.

Jewish Agency for Palestine. Memorandum Submitted to the Anglo-American Committee of Inquiry on Palestine, 1946.

United Nations Organization. International Trusteeship System and the Trusteeship System, 1957.

United Nations Organization. Documents of the United Nations Conference on International Organization, 1945.

Woodrow Wilson Foundation. Proposals for the Establishment of a General International Organization, 1944.

\section{Periodicals AND NeWSPAPERS}

The Globe and Mail (Toronto), 1945-1947.

The New York Times, 1929-1947.

The Times (London), 1930-1947.

The Whig Standard (Kingston), 1933.

Toronto Star, 1942-1947.

\section{MEMOIRS AND COMPILATIONS}

Earl of Oxford and Asquith, Memories and Reflections, 1852-1927, Vol. 2 (Boston: Little, Brown, and Company, 1928).

Brandeis, Louis. Brandeis on Zionism: A Collection of Addresses and Statements by Louis D. Brandeis (Washington D. C.: Zionist Organization of America, 1942).

Canadian Institute of International Affairs (CIIA). A Bibliography of Works on Canadian Foreign Relations, 1945-1970 (Toronto: CIIA, 1973).

A Bibliography of Works on Canadian Foreign Relations, 19711975

(Toronto: CIIA, 1977).

A Bibliography of Works on Canadian Foreign Relations, 1976-1980

(Toronto: CIIA, 1981). 
A Bibliography of Works on Canadian Foreign Relations, 1981-1985 (Toronto: CIIA, 1987).

A Bibliography of Works on Canadian Foreign Relations, 1991-1995

(Toronto: CIIA, 1998).

Eban, Abba. An Autobiography (New York: Random House, 1977).

Eden, Anthony. The Eden Memoirs: The Reckoning (London: Cassell and Company, 1965).

Elath, Eliahu. Zionism at the United Nations: A Diary of the First Days (Philadelphia, PA: The Jewish Publication Society of America, 1976).

Gildersleeve, Virginia Crocheron. Many a Good Crusade (New York: The MacMillan Company, 1955).

Hillmer, Norman, ed. O. D. Skelton: The Work of the World, 1923-1941 (Kingston and Montreal: McGill-Queen's University Press, 2013).

Hull, Cordell. The Memoirs of Cordell Hull, Vol. 1 (New York: MacMillan Company, 1948).

Ignatieff, George. The Making of a Peacemonger: The Memoirs of George Ignatieff (Toronto: University of Toronto Press, 1985).

Keenleyside, Hugh. Hammer the Golden Day: Memoirs of Hugh L. Keenleyside, Vol. 1 (Toronto: McClelland and Stewart, 1981).

On the Bridge of Time: Memoirs of Hugh L. Keenleyside, Vol. 2 (Toronto: McClelland and Stewart, 1982).

Pearson, Lester B. Mike: The Memoirs of the Right Honourable Lester B. Pearson, Vol. 1, 1897-1948 (Toronto: Toronto University Press, 1972).

Pickersgill, J. W., ed. The Mackenzie King Record: Vol. 1, 1939-1944 (Chicago: Chicago University Press, 1960).

Pickersgill, J. W. and D. F. Forster, eds. The Mackenzie King Record: Vol. 2, 19441945 (Toronto: University of Toronto Press, 1968).

University of Toronto Press, 1970).

The Mackenzie King Record: Vol. 3, 1945-1946 (Toronto:

The Mackenzie King Record: Vol. 4, 1947-1948 (Toronto: University of Toronto Press, 1970).

Reid, Escott. Radical Mandarin: The Memoirs of Escott Reid (Toronto: University of Toronto Press, 1989).

On Duty: A Canadian at the Making of the United Nations, 19451946 (Toronto: McClelland and Stewart Limited, 1983).

Storrs, Ronald. The Memoirs of Sir Ronald Storrs (New York: G. P. Putnam's Sons, 1937). 
Truman, Harry S. Memoirs, Years of Trial and Hope, Vol. 1, 1946-1952 (Garden City, NY: Doubleday \& Company 1956).

Weizmann, Chaim. Trial and Error: The Autobiography of Chaim Weizmann, Vol. 1 (Philadelphia: The Jewish Publication Society of America, 1949).

\section{CONTEMPORARY ACCOUNTS}

\section{(a) Books}

Adler, Cyrus and Aaron M. Margolith. With Firmness in the Right: American Diplomatic Actions Affecting Jews, 1840-1945 (New York: The American Jewish Committee, 1946).

Antonius, George. The Arab Awakening (New York: G. P. Putnam's Sons, 1946).

Bentwich, Norman. Palestine (London: Ernest Benn Limited, 1946).

Chambers, Frank. The War behind the War (New York: Harcourt, Brace \& Co., 1939).

Cocks, Seymour F. The Secret Treaties and Understandings (London: Union of Democratic Control, 1918).

Crossman, Richard. Palestine: A Personal Record (New York: Harper \& Brothers Publishers, 1947).

Earle, Edward Meade. Turkey, The Great Powers and the Bagdad Railway: A Study in Imperialism (New York: Macmillan Co., 1923).

Esco Foundation. Palestine: A Study of Jewish, Arab, and British Policies, Vol. 1 and 2 (New Haven, Conn.: Yale University Press, 1947).

Hailey, Lord. The Future of Colonial Peoples (London: Oxford University Press, 1943).

Hall, Duncan H. Mandates, Dependencies, and Trusteeship (London: Stevens \& Sons Limited, 1948).

Hythe, Viscount and J. Leyland, eds. The Naval Annual, 1914 (Portsmouth, Britain: J. Griffith and Co., 1914).

Ireland, Philip Willard. Iraq: A Study in Political Development (London: Jonathan Cape Ltd., 1937).

Kohn, Hans. Nationalism and Imperialism in the Hither East (New York: Harcourt, Brace, and Co., 1932).

Loder, J. De V. The Truth about Mesopotamia, Palestine \& Syria (London: George Allen \& Unwin Ltd., 1923).

Lloyd George, David. The Truth About the Peace Treaties (London: Victor Golancz Ltd., 1938). 
MacMunn, Sir George Fletcher and Cyril Falls. Military Operations, Egypt \& Palestine from the Outbreak of the War with Germany to June 1917, Vol. 1 (London: Government of Great Britain, 1930).

Monroe, Elizabeth. The Mediterranean in Politics (London: Oxford University Press, 1938).

Murray, Gilbert. The Foreign Policy of Sir Edward Grey, 1906-1915 (Oxford: Clarendon Press, 1915).

Sakran, Frank C. Palestine Dilemma: Arab Rights versus Zionist Aspirations (Washington, D. C.: Public Affairs Press, 1948).

Tolstoy, L. N. Resurrection (New York: Thomas Y. Crowell, 1911).

Wilson, A. T. The Persian Gulf(Oxford: Clarendon Press, 1928).

White, Freda. Mandates (London: Jonathan Cape Ltd., 1926).

Wright, Quincy. Mandates under the League of Nations (New York: Greenwood Press, 1930).

\section{(b) Articles}

Antonius, George. "Syria and the French Mandate," International Affairs, Vol. 13, No. 4 (July-August, 1934), pp. 523-539.

Atiyah, Edward. "Palestine: An Arab View," The Spectator, May 10, 1946, pp. 1-3.

D. K. "The Trusteeship Proposals at San Francisco," The World Today, Vol. 1, No. 2 (August, 1945), pp. 76-86.

Earle, Edward Meade. "The Importance of the Near East in Problems of Raw Materials and Foodstuffs," Annals of the American Academy of Political and Social Sciences, Vol. 112 (March, 1924), pp. 183-186.

"The Turkish Petroleum Company: A Study in Oleaginous

Diplomacy," Political Science Quarterly, Vol. 39, No. 2 (June, 1924), pp. 265-279.

"American Missions in the Near East," Foreign Affairs,

Vol. 7, No. 3 (April, 1929), pp. 398-417.

Faisal, Amir. "Notes on the Arab Question," Fortnightly Review, Vol. 136 (1929), pp. 735-736.

Fraser, Blair. "Our Diplomats at Work," Behind the Scenes, Vol. 5, No. 3 (Series 1945), pp. 1-31.

Gilchrist, Huntington. "V. Colonial Questions at the San Francisco Conference," American Political Science Review, Vol. 39, No. 5 (October, 1945), pp. 982-992.

H. L. "Great Britain and Palestine," Bulletin of International News, Vol. 7, No. 8 (October 8, 1930), pp. 3-12.

Hogarth, David G. "Wahabism and British Interests," Journal of the British Institute of International Affairs, Vol. 4, No. 2 (March, 1925), pp. 70-81. 
Holcombe, Arthur. N. "The International Trusteeship System," Annals of the American Academy of Political and Social Science, Vol. 246, Making the United Nations Work (July, 1946), pp. 101-109.

Howard, Harry. "The Soviet Union and the Middle East," Annals of American Academy of Political and Social Sciences, Vol. 263, The Soviet Union Since World War Two (May, 1949), pp. 180-187.

Hoskins, Halford L. "Background of the British Position in Arabia," Middle East Journal, Vol. 1, No. 2 (April, 1947), pp. 137-147.

J. R. "The Background of Russo-Turkish Relations," The World Today, Vol. 2, No. 2 (February, 1946), pp. 58-59.

W. A. Mackintosh, "Canada's Stake in Anglo-American Solidarity," Foreign Affairs, Vol. 28, No. 1 (October, 1949), pp. 18-29.

Mills, Mark Carter. "The Mandatory System," The American Journal of International Law, Vol. 17, No. 1 (January, 1923), pp. 63-76.

Peel, Earl. "The Report of the Palestine Commission," International Affairs, Vol. 16, No. 5 (September, 1937), pp. 761-779.

Rand, I. C. "Louis D. Brandeis," The Canadian Bar Review, Vol. 25, No. 3 (March, 1947), pp. 240-250.

Samuel, Viscount. "Alternatives to Partition," Foreign Affairs, Vol. 16, No. 1 (October, 1937), pp. 143-155.

Seeger, Charles. "On Dissonant Counterpoint," Modern Music, Vol. 7, No. 4 (JuneJuly, 1930), pp. 25-26.

"Egypt-Iraq-Lebanon-Saudi Arabia-Syria-Transjordan-Yemen: Text of the Pact of the Arab League," The American Journal of International Law, Vol. 39, No. 4, Supplement: Official Documents (October, 1945), pp. 266-272.

Western, Maurice. "Canada's Role in the Second Assembly," International Journal, Vol. 3, No. 2 (Spring, 1948), pp. 120-131.

Woodhead, John. "The Report of the Palestine Partition Commission," International Affairs, Vol. 18, No. 2 (March-April, 1939), pp. 171-193.

Wright, Quincy. "Sovereignty of the Mandates," The American Journal of International Law, Vol. 17, No. 4 (October, 1923), pp. 691-703.

"The Bombardment of Damascus," The American Journal of International Law, Vol. 20, No. 2 (April 1926), pp. 263-280. 


\section{SECONDARY SOURCES:}

(a) Books

Abella, Irving and Harold Troper. None is Too Many: Canada and the Jews of Europe, 1933-1948 (Toronto: Lester \& Orpen Dennys Ltd., 1982).

Albrecht-Carrié, René. A Diplomatic History of Europe: Since the Congress of Vienna (London: Methuen \& Co. Ltd., 1965).

Anderson, Violet, ed. The United Nations Today \& Tomorrow (Toronto: Ryerson Press, 1943).

Archibald, Kathleen. Sex and the Public Service: A Report to the Public Service Commission of Canada (Ottawa: Public Service Commission of Canada, 1973).

Aster, Sidney, ed. The Second World War as a National Experience (Ottawa: The Canadian Committee for the History of the Second World War and the Department of National Defence, 1981).

Avery, Donald. Reluctant Host: Canada's Response to Immigrant Workers, 18961994 (Toronto: McClelland \& Stewart Inc., 1995).

Bain, William. Between Anarchy and Society: Trusteeship and the Obligations of Power (London: Oxford University Press, 2003).

Barr, James. A Line in the Sand: Britain, France and the Struggle for the Mastery of the Middle East (London: Simon \& Schuster, 2011).

Bercuson, David J. Canada and the Birth of Israel: A Study in Canadian Foreign Policy (Toronto: University of Toronto Press, 1985).

Bernier, Serge and John MacFarlane, eds. Canada, 1900-1950, A Country Comes of Age (Ottawa: Organization for the History of Canada, 2003).

Bothwell, Robert and Norman Hillmer, eds. The In-Between Time: Canadian External Policy in the 1930s (Toronto: Copp Clark Publishing, 1975).

Bothwell, Robert. Alliance and Illusion: Canada and the World, 1945-1984 (Vancouver: UBC Press, 2007).

Bullock, Alan. Ernest Bevin: Foreign Secretary, 1945-1951(New York: W. W. Norton \& Company, 1983).

Busch, Briton Cooper. Britain, India, and the Arabs, 1914-1921 (Berkeley, Calif.: University of California Press, 1971).

Broadberry, Stephen and Mark Harrison, eds. The Economy of World War One (London: Cambridge University Press, 2005).

Burridge, Trevor. Clement Attlee: A Political Biography (London: Jonathan Cape Ltd., 1985). 
Burt, Sandra, Lorraine Code, and Lindsay Dorney, eds. Changing Patterns: Women in Canada, Second Edition (Toronto: McClelland \& Stewart Inc., 1993).

Cadieux, Marcel. The Canadian Diplomat, translated by Archibald Day (Toronto: University of Toronto Press, 1962).

Carment, David, Fen Osler Hampson, and Norman Hillmer, eds. Canada Among Nations, 2003: Coping with the American Colossus (Don Mills, ON: Oxford University Press, 2003).

Chaitani, Youssef. Dissension Among Allies: Ernest Bevin's Palestine Policy Between Whitehall and the White House, 1945-47 (London: Saqi Books, 2002).

Clarke, Peter. The Last Thousand Days of the British Empire (New York: Bloomsbury Press, 2008).

Cohen, Gerard Daniel. In War's Wake: Europe's Displaced Persons in the Postwar Order (New York: Oxford University Press, 2012).

Cooper, Andrew Fenton, ed. Canadian Culture: International Dimensions (Waterloo, ON: Centre on Foreign Policy and Federalism, University of Waterloo/Wilfrid Laurier University, Canadian Institute of International Affairs, 1985).

Corbett, E. A. Henry Marshall Tory: Beloved Canadian (Toronto: The Ryerson Press, 1954).

Crowley, Terry. Marriage of Minds: Isabel and Oscar Skelton Reinventing Canada (Toronto: University of Toronto Press, 2003).

Dallek, Robert. Franklin D. Roosevelt and American Foreign Policy, 1932-1945 (New York: Oxford University Press, 1979).

Dallin, Alexander. The Soviet Union and the United Nations: An Inquiry into Soviet Motives and Objectives (New York: Frederick A. Praeger, 1962).

Dalton, Hugh. The Fateful Years, 1931-1945, Vol. 1 (London: Frederick Muller, Ltd., 1957).

Dawn, C. Ernest. From Ottomanism to Arabism: Essays on the Origins of Arab Nationalism (Chicago: University of Illinois Press, 1973).

Dennis, Donald Phillips. Foreign Policy in Democracy: The Role of the Foreign Policy Association (New York: Foreign Policy Association Global Visions Books, 2003).

Donaghy, Greg and Kim Richard Nossal, eds. Architects and Innovators: Building the Department of Foreign Affairs and International Trade, 1909-2009 (Montreal \& Kingston: McGill-Queen's University Press, 2009).

Earle, Edward Meade. Modern France: Problems of the Third and Fourth Republics (Princeton, N. J.: Princeton University Press, 1951).

Eayrs, James. The Art of the Possible: Government and Foreign Policy in Canada (Toronto: University of Toronto Press, 1961). 
In Defence of Canada: Appeasement and Rearmament (Toronto: University of Toronto Press, 1965).

In Defence of Canada: Peacemaking and Deterrence (Toronto: University of Toronto Press, 1972).

English, John. Shadow of Heaven: The Life of Lester B Pearson, Vol. 1, 1897-1948 (Toronto: Lester \& Orpen Dennys Publishers, 1989).

Esposito, John. What Everyone Needs to Know about Islam (New York: Oxford University Press, 2002).

Feis, Herbert. The Birth of Israel: The Tousled Diplomatic Bed (New York: W. W. Norton \& Company, 1969).

Ferguson, Barry. Remaking Liberalism: The Intellectual Legacy of Adam Shortt, O. D. Skelton, W. C. Clark and W. A. Mackintosh, 1890-1925 (Montreal \& Kingston: McGill-Queen's University Press, 1993).

Fromkin, David. A Peace to End All Peace: The Fall of the Ottoman Empire and the Creation of the Modern Middle East (New York: Henry Holt and Company, 2001).

Granatstein, J. L. A Man of Influence: Norman A. Robertson and Canadian Statecraft, 1929-1960 (Toronto: Deneau Publishers, 1981).

The Ottawa Men: The Civil Service Mandarins, 1935-1957 (Toronto:

Oxford University Press, 1982).

Guinn, Paul. British Strategy and Politics 1914-1918 (Clarendon Press: Oxford University Press. 1969).

Hadawi, Sami. Bitter Harvest: A Modern History of Palestine (New York: Olive Branch Press, 1991).

Harkabi, Yehoshafat. Israel's Fateful Hour (New York: Harper \& Row, Publishers, 1988).

Heinbecker, Paul and Bessma Momani, eds. Canada and the Middle East: In Theory and Practice (Waterloo, ON: Wilfrid Laurier University Press, 2007).

Hilliker, John F. Canada's Department of External Affairs: Vol. 1, The Early Years, 1909-1946 (Montreal \& Kingston: McGill-Queen's University Press, 1990).

Hilliker, John F and Donald Barry. Canada's Department of External Affairs: Vol. 2, Coming of Age, 1946-1968 (Montreal and Kingston: McGill-Queen's University Press, 1995).

Hillmer, Norman and J. L. Granatstein, eds. The Land Newly Found: Eyewitness Accounts of the Canadian Immigrant Experience (Toronto: Thomas Allen Publishers, 2006).

Hillmer, Norman. O. D. Skelton: A Life in the Arena (manuscript). 
Hodgetts, J. E., William McCloskey, Reginald Whitaker, and V. Seymour Wilson. The Biography of an Institution: The Civil Service of Canada, 1908-1967 (Montreal and Kingston: McGill-Queen's University Press, 1972).

Holmes, John. The Shaping of Peace: Canada and the Search for World Order, 19431957, Vol. 1 (Toronto: University of Toronto Press, 1979).

The Shaping of Peace: Canada and the Search for World Order, 19431957, Vol. 2 (Toronto: University of Toronto Press, 1982).

Horowitz, David. State in the Making (New York: Alfred A. Knopf, Inc., 1953).

Hourani, Albert. A History of the Arab Peoples (Cambridge, Mass.: The Belknap Press of Harvard University Press, 2002).

Hurewitz, J. C. The Struggle for Palestine (New York: W. W. Norton \& Company, Inc., 1950).

Isacoff, Jonathan. Writing the Arab-Israeli Conflict: Pragmatism and Historical Inquiry (Lanham, MD: Lexington Books, 2006).

Ismael, Tareq Y. and Peyton Lyon, eds. Canada and the Arab World (Edmonton: University of Alberta Press, 1985).

Judt, Tony. Postwar: A History of Europe since 1945 (New York: Penguin Books, 2005).

Kaplan, William. Canadian Maverick: The Life and Times of Ivan C. Rand (Toronto: University of Toronto Press, 2009).

Karsh, Efraim. Palestine Betrayed (New Haven, Mass.: Yale University Press, 2010).

Kay, Zachariah. The Diplomacy of Prudence: Canada and Israel, 1948-1958 (Montreal: McGill-Queen's University Press, 1996).

Canada and Palestine: The Politics of Non-Commitment (Jerusalem: Israel Universities Press, 1978).

The Diplomacy of Impartiality: Canada and Israel, 1958-1968 (Waterloo, ON: Wilfrid Laurier University Press, 2010).

Keay, John. Sowing the Wind: The Seeds of Conflict in the Middle East (New York: W. W. Norton \& Company, 2003).

Kedourie, Elie. In the Anglo-Arab Labyrinth: The McMahon-Husayn Correspondence and its Interpretations, 1914-1939 (London: Frank Cass, 2000).

Kirton, John. Canada as a Principal Power (Toronto: John Wiley \& Sons, 1983).

2007).

Canadian Foreign Policy in a Changing World (Toronto: Nelson,

Kerr, Stanley E. The Lions of Marash: Personal Experiences with American Near East Relief, 1919-1922 (Albany, N. Y.: State University of New York, 1973). 
Khalidi, Rashid. Sowing Crisis: The Cold War and American Dominance in the Middle East (Boston: Beacon Press, 2009).

All That Remains: The Palestinian Villages Occupied and Depopulated by Israel in 1948 (Washington, D.C.: Institute for Palestine Studies, 1992).

Khouri, Fred J. The Arab-Israeli Dilemma (Syracuse, New York: Syracuse University Press, 1985).

Klieman, Aaron. Foundations of British Policy in the Arab World: The Cairo Conference of 1921 (Baltimore: John Hopkins Press, 1970).

Laqueur, Walter. A History of Zionism: From the French Revolution to the Establishment of the State of Israel (New York: Schocken Books, 1972).

Leffler, Melvyn P. A Preponderance of Power: National Security, the Truman Administration, and the Cold War (Stanford, CA: Stanford University Press, 1992).

Longhurst, Henry. Adventure in Oil: The Story of British Petroleum (London: Sidwick and Jackson, 1959).

Louis, Wm. Roger. The British Empire in the Middle East, 1945-1951 (Oxford: Clarendon Press, 1984).

Clarendon Press, 1967).

Great Britain \& Germany's Lost Colonies, 1914-1919 (Oxford:

Imperialism at Bay: The United States and the Decolonization of the British Empire, 1941-1945 (New York: Oxford University Press, 1978).

Louis, Wm. Roger and Robert W. Stookey, eds. The End of the Palestine Mandate (London: I. B. Tauris \& Co., 1986).

Love, Kenneth. Suez: The Twice-Fought War (London: Longman, 1969).

Luard, Evan. A History of the United Nations: The Years of Western Domination, Vol. 1, 1945-1955 (New York: The MacMillan Press, 1982).

Makovsky, Michael. Churchill's Promised Land: Zionism and Statecraft (New Haven, Conn.: Yale University Press, 2007).

Masalha, Nur. The Palestine Nakba: Decolonizing History, Narrating the Subaltern, Reclaiming Memory (London: Zed Books, 2012).

McCullough, David. Truman (New York: Simon \& Schuster, 1992).

Marlowe, John. Anglo-Egyptian Relations, 1800-1953 (London: The Cresset Press, 1954).

Arab Nationalism \& British Imperialism: A Study in Power Politics (London: The Cresset Press, 1961).

The Seat of Pilate: An Account of the Palestine Mandate (London: The Cresset Press, 1959). 
MacDermaid, Ann and George F. Henderson, eds. Through Scholarly Eyes: Queen's University Archives Lectures, 1983-1991 (Kingston: Queen's University Press, 1991).

Massoud, M. S. I Fought as I Believed (Montréal: Ateliers Des Sourds Inc., 1975).

McKercher, B. J. C. and Lawrence Aronsen, eds. The North Atlantic Triangle in a Changing World: Anglo-American-Canadian Relations, 1902-1956 (Toronto: University of Toronto Press, 1996).

McNamara, Robert. The Hashemites: The Dream of Arabia (London: Haus Publishing Ltd., 2009).

Mayer, Arno. Plowshares into Swords: From Zionism to Israel (New York: Verso, 2008).

Mossek, M. Palestine Immigration Policy under Sir Herbert Samuel (London: Frank Cass \& Co., 1978).

Monroe, Elizabeth. Britain's Moment in the Middle East, 1914-1956 (Baltimore: John Hopkins Press, 1963).

Morris, Benny. Righteous Victims: A History of the Zionist-Arab Conflict, 1881-1999 (New York: Alfred A. Knopf, 1999).

Press, 2008).

1948: The First Arab-Israeli War (New Haven, Conn.: Yale University

The Birth of the Palestinian Refugee Problem Revisited (Cambridge:

Cambridge University Press, 2004).

Murphy, Bruce Allen. The Brandeis-Frankfurter Connection: The Secret Political Activities of Two Supreme Court Justices (New York: Oxford University Press, 1982).

Nevakivi, Jukka. Britain, France and the Arab Middle East, 1914-1920 (London: The Athlone Press, 1969).

Norrie, Kenneth, Doug Owram, and J. C. Herbert Emery. A History of the Canadian Economy, (Toronto: Thomson Canada Ltd., 2002).

Owram, Doug. The Government Generation: Canadian Intellectuals and the State, 1900-1945 (Toronto: University of Toronto, 1986).

Padwick, Constance E. Call to Istanbul (London: Longmans, Green and Co., 1958).

Pogue, Forrest. George C. Marshall: Statesman, 1945-1959 (New York: Viking Penguin Inc., 1987).

Province, Michael. The Great Syrian Revolt and the Rise of Arab Nationalism (Austin, TX.: University of Texas Press, 2005).

Robinson, Kenneth. The Dilemmas of Trusteeship: Aspects of British Colonial Policy between the Wars (London: Oxford University Press, 1965). 
Rogan, Eugene L. and Avi Shlaim, eds. The War for Palestine: Rewriting the History of 1948 (Cambridge: Cambridge University Press, 2001).

Royal Institute of International Affairs. The Middle East: A Political and Economic Survey (London: Royal Institute of International Affairs, 1950).

Royal Institute of International Affairs. Great Britain and Palestine, 1915-1945 (Westport, Conn.: Hyperion Press Inc., 1976).

Rubin, Barry. The Arab States and the Palestine Conflict (Syracuse, N.Y.: Syracuse University Press, 1981).

Russell, Ruth B. and Jeannette E. Muther. A History of the United Nations Charter: The Role of the United States, 1940-1945 (Washington, D.C.: Brookings Institute, 1958).

Sachar, Howard M. The Emergence of the Middle East: 1914-1924 (New York: Alfred A. Knopf, 1969).

Salt, Jeremy. The Unmaking of the Middle East: A History of Western Disorder in Arab Lands (Berkeley, CA: University of California Press, 2008).

Scott, Joan Wallach. Gender and the Politics of History (New York: Columbia University Press, 1988).

Schneer, Jonathan. The Balfour Declaration: The Origins of the Arab-Israeli Conflict (Toronto: Bond Street Books, 2010).

Shadid, Mohammed. The United States and the Palestinians (New York: St. Martin's Press, 1981).

Shephard, Ben. The Long Road Home: The Aftermath of the Second World War (New York: Anchor Books, 2012).

Shlaim, Avi. The Politics of Partition: King Abdullah, the Zionists and Palestine, 1921-1951 (Oxford: Oxford University Press, 1990).

The Iron Wall: Israel and the Arab World (New York: W. W. Norton \& Co., 2000).

Skilling, H. Gordon. Canadian Representation Abroad: From Agency to Embassy (Toronto: Ryerson Press, 1945).

Soward, F. H. Canada in World Affairs: From Normandy to Paris, 1944-1946 (Toronto: Oxford University Press, 1950).

Soward, F. H. and Edgar McInnis. Canada and the United Nations (New York: Manhattan Publishing Company, 1956).

Spencer, Robert A. Canada in World Affairs: From UN to NATO, 1946-1949 (Toronto: Oxford University Press, 1959).

Spiegel, Steven, ed. The Middle East and the Western Alliance (London: Allen \& Allen, 1982). 
Stein, Janice Gross and David B. Dewitt, eds. The Middle East at the Crossroads: Regional Forces \& External Power (Oakville, ON: Mosaic Press, 1983).

Stein, Leonard. The Balfour Declaration (New York: Simon \& Schuster, 1961).

Stevens, Richard P. American Zionism and U. S. Foreign Policy, 1942-1947 (New York: Pageant Press, Inc., 1962).

Strong-Boag, Veronica and Anita Chair Fellman, eds. Rethinking Canada: The Promise of Women's History, (Toronto: Copp Clark Pitman Ltd., 1986).

Stursberg, Peter, ed. Lester Pearson and the Dream of Unity (Toronto: Doubleday Canada, 1978).

Canada Ltd., 1980).

, ed. Lester Pearson and the American Dream (Toronto: Doubleday

Sykes, Christopher. Crossroads to Israel: Palestine from Balfour to Bevin (London: Collins, 1965).

Taras, David and David Goldberg, eds. The Domestic Battleground: Canada and the Arab-Israeli Conflict (Kingston, Ont.: McGill-Queen's University Press, 1989).

Tauber, Eliezer. Personal Policymaking: Canada's Role in the Adoption of the Palestine Partition Resolution (Westport, Conn.: Greenwood Press, 2002).

Taylor, Alan R. Prelude to Israel: An Analysis of Zionist Diplomacy, 1897-1947 (New York: Philosophical Library, 1959).

Toye, Richard. Churchill's Empire (New York: Henry Holt and Company, 2010).

Toynbee, Arnold and Frank T. Ashton-Gwatkin, eds. Survey of International Affairs, 1939-1946: The World in March, 1939 (London: Oxford University Press, 1952).

Tucker, Michael. Canadian Foreign Policy: Contemporary Issues and Themes. (Toronto: McGraw-Hill Ryerson Limited, 1980).

Urquhart, Brian. Ralph Bunche: An American Odyssey (New York: W. W. Norton \& Co., 1998).

Company, 1993).

Ralph Bunche: An American Life (New York: W. W. Norton \&

Wasserstein, Bernard. Britain and the Jews of Europe, 1939-1945 (Oxford: Clarendon Press, 1979).

Weiers, Margaret K. Envoys Extraordinary: Women of the Canadian Foreign Service (Toronto: Dundurn Press, 1995).

Wilson, Harold. The Chariot of Israel: Britain, America, and the State of Israel (New York: W. W. Norton \& Company, 1981).

Winstone, H. V. Gertrude Bell (London: Jonathan Cape, 1978). 
Wolfe, Robert, ed. Diplomatic Missions: The Ambassador in Canadian Foreign Policy (Kingston: School of Policy Studies, Queen's University, 1998).

Yergin, David. The Prize: The Epic Quest for Oil, Money, and Power (New York: Simon \& Schuster, 1991).

Zubok, Vladislav and Constantine Pleshakov. Inside the Kremlin's Cold War: From Stalin to Khrushchev (Cambridge, MA: Harvard University Press, 1996).

\section{(b) Articles}

Abboushi, W. F. "The Road to Rebellion: Arab Palestine in the 1930s," Journal of Palestine Studies, Vol. 6, No. 3 (Spring, 1977), pp. 23-46.

Acker, Joan. "Hierarchy, Job Bodies: A Theory of Gendered Organizations," Gender and Society, Vol. 4, No. 2 (June, 1990), pp. 139-158.

Baron, Lawrence. "The First Wave of American 'Holocaust Films, 1945-1959," The Historical Review, Vol. 115, No. 1 (February, 2010), pp. 90-114.

Blakeney, Michael. "Proposals for a Jewish Colony in Australia: 1938-1948," Jewish Social Studies, Vol. 46, No. 3-4 (Summer-Autumn, 1984), pp. 277-292.

Caplan, Neil. "Zionism and the Arabs: Another Look at the "New' Historiography," Journal of Contemporary History, Vol. 36, No. 2 (April, 2001), pp. 345-360.

Cohen, Michael. "Churchill and the Jews: The Holocaust," Modern Judaism, Vol. 6, No. 1 (February, 1986), pp. 27-49.

"William A. Eddy, the Oil Lobby and the Palestine Problem," Middle Eastern Studies, Vol. 30, No. 1 (January, 1994), p. 166-180.

Cohen, Stuart. "Mesopotamia in British Strategy, 1903-1914," International Journal of Middle East Studies, Vol. 9, No. 2 (April, 1978), pp. 171-181.

Dulles, Foster Rhea and Gerald E. Ridinger. "The Anti-Colonial Policies of Franklin D. Roosevelt," Political Science Quarterly, Vol. 70, No. 1 (March, 1955), pp. 1-18.

El-Eini, Roza I. M. "The Implementation of British Agricultural Policy in Palestine in the 1930s," Middle Eastern Studies, Vol. 32, No. 4 (October, 1996), pp. 211-250.

Esmeir, Samera. "1948: Law, History, Memory," Social Text, Vol. 21, No. 2 (Summer, 2003), pp. 25-48.

Ettinger, Julia. "Elizabeth MacCallum: A Graduate Profile," The Queen's Review (November, 1952), pp. 214-216.

Evensen, Bruce J. "The Limits of Presidential Leadership: Truman at War with Zionists, the Press, Public Opinion and His Own State Department over Palestine," Presidential Studies of Quarterly, Vol. 23, No. 2, President, Perception and Persuasion (Spring, 1993), pp. 269-287. 
Fitzgerald, Peter Edward. "France's Middle Eastern Ambitions, the Sykes-Picot Negotiations, and the Oil Fields of Mosul, 1915-1918," The Journal of Modern History, Vol. 66, No. 4 (December, 1994), pp. 697-725.

Fortin, Nicole M. and Michael Huberman. "Occupational Gender Segregation and Women's Wages in Canada: An Historical Perspective," Canadian Public Policy, Vol. 28, Supplement: Occupational Gender Segregation: Public Policies and Economic Forces (May, 2002), pp. S11-S39.

Freitag, Ulrike. "Writing Arab History: The Search for the Nation," British Journal of Middle East Studies, Vol. 21, No. 1 (1994), pp. 19-37.

Friedman, Isaiah. "The McMahon-Husayn Correspondence and the Question of Palestine," Journal of Contemporary History, Vol. 5, No. 2 (1970), pp. 83-122.

Gillon, D. Z. "The Antecedents of the Balfour Declaration," Middle East Studies, Vol. 5, No. 2 (May, 1969), pp. 131-150.

Halliday, Fred. "Hidden from International Relations: Women and the International Arena," Millennium: Journal of International Studies, Vol. 17, No. 3 (1988), pp. 419428.

Halperin, Samuel and Irvin Oder. "The United States in Search of a Policy: Franklin D. Roosevelt and Palestine," The Review of Politics, Vol. 24, No. 3 (July, 1962), pp. 320-341.

Hardy, Allison T. "Women: Always Diplomatic and Recently Diplomats," International Perspectives (July-August, 1976), pp. 26-32.

Haas, Ernest. "The Attempts to Terminate Colonialism: Acceptance of the United Nations Trusteeship System," International Organization, Vol. 7, No. 1 (February, 1953), pp. 1-21.

Helmreich, Paul C. "Italy and the Anglo-French Repudiation of the 1917 St. Jean de Maurienne Agreement," The Journal of Modern History, Vol. 48, No. 2, On Demand Supplement (June, 1976), pp. 99-139.

Hillmer, Anne Trowell. "A Remembrance: Elizabeth Pauline MacCallum," bout de papier, No. 2, Vol. 3 (Summer, 1985), pp. 14-15.

Hillmer, Norman. "The Foreign Policy that Never Was," in Serge Bernier and John MacFarlane, eds. Canada, 1900-1950, A Country Comes of Age. (Ottawa: Organization for the History of Canada, 2003).

Hughes, Vivien. "Women, Gender, and Canadian Foreign Policy, 1909-2009," British Journal of Canadian Studies, Vol. 23, No. 2 (2010), pp. 159-178.

Husseini, Hassan. "A 'Middle Power' in Action: Canada and the Partition of Palestine," Arab Studies Quarterly, Vol. 30, No. 3 (Summer, 2008), pp. 41-55. 
Isacoff, Jonathan. "Writing the Arab-Israeli Conflict: Historical Bias and the Use of History and Political Science," Perspectives on Politics, Vol. 3, No. 1 (March, 2005), pp. 71-88.

Julien, C. A. "From the French Empire to the French Union," Royal Institute of International Affairs, Vol. 26, No. 4 (October, 1950), pp. 487-502.

Karlinsky, Nahum. "Beyond Post-Zionism," Israeli Studies, Vol. 9, No. 3 (Fall, 2004), pp. 169-181.

Kay, Zachariah. "The Canadian Press and Palestine: A Survey, 1939-1948," International Journal, Vol. 18, No. 3 (Summer, 1963), pp. 361-373.

Khalidi, Walid. "Albert Hourani, the Arab Office, and the Anglo-American Committee of 1946," Journal of Palestine Studies, Vol. 35, No. 1 (Autumn, 2005), pp. 60-79.

Khoury, Phillip S. "Factionalism Among Syrian Nationalists during the French Mandate," International Journal of Middle East Studies, Vol. 13, No. 4 (November, 1981), pp. 441-469.

Lawson, Fred. "The Iranian Crisis of 1945-1946 and the Spiral Model of International Conflict," International Journal of Middle East Studies, Vol. 21, No. 3 (August, 1989), pp. 307-326.

Liebesny, Herbert J. and J. C. Hurewitz. "Developments of the Quarter: Comment and Chronology, June 1-August 31, 1947," Middle East Institute, Vol. 1, No. 4 (October, 1947), pp. 432-448.

Likhovski, Assaf. "Post-Post Zionist Historiography," Israeli Studies, Vol. 15, No. 2 (Summer, 2010), pp. 1-23.

Louis, Wm. Roger. "African Origins of the Mandates Idea," International Organization, Vol. 19, No. 1 (Winter, 1965), pp. 20-36.

Maissy-Noy, Rachel. "Palestinian Historiography in Relation to the Territory of Palestine," Middle East Studies, Vol. 42, No. 6 (November, 2006), pp. 889-905.

Manuel, Frank E. "The Palestine Question in Italian Diplomacy, 1917-1920," The Journal of Modern History, Vol. 27, No. 3 (September, 1955), pp. 263-280.

Massad, Joseph. "The Persistence of the Palestinian Question," Cultural Critique, No. 59 (Winter, 2005), pp. 1-23.

Medoff, Rafael. "In Recent Trends in the Historiography of Zionism: A Review Essay,” Modern Judaism, Vol. 15, No. 1 (February, 1995), pp. 95-101.

Melson, Robert. "A Theoretical Inquiry into the Armenian Massacre of 1894-1896," Comparative Studies in Society and History, Vol. 24, No. 3 (July, 1982), pp. 481-509.

Morris, Benny. "Palestinian Identity: The Construction of Modern National Consciousness," Israeli Studies, Vol. 3, No. 1 (Spring, 1998), pp. 266-272. 
Naiden, F. S. "Lines in the Sand," The Wilson Quarterly, Vol. 31, No. 1 (Winter, 2007), pp. 52-63.

Naor, Arye. "A Matter of Distoriography: Efraim Karsh, the 'New Historians' of Israel, Their Methodology and Perspective," Israeli Studies, Vol. 6, No. 2 (Summer, 2001), pp. 139-150.

Nevo, Joseph. "The Arabs of Palestine 1947-48: Military and Political Activity," Middle Eastern Studies, Vol. 23, No. 1 (January, 1987), pp. 3-38.

Neuburger, Hugh and Houston H. Stokes. "The Anglo-German Trade Rivalry, 18871913: A Counterfactual Outcome and its Implications," Social Science History, Vol. 3, No. 2 (Winter, 1979), pp. 187-201.

Ofer, Pinhas. "The Commission on the Palestine Disturbances of August 1929: Appointment, Terms of Reference, Procedure and Report," Middle Eastern Studies, Vol. 21, No. 3 (July, 1985), pp. 349-361.

Pappé, Ilan. 'Humanizing the Text: Israeli 'New History' and the Trajectory of the 1948 Historiography,” Radical History Review, Issue 86 (Spring, 2003), pp. 102-122.

"The Post-Territorial Dimensions of the Future Homeland in Israel and Palestine," Comparative Studies of South Asia, Africa and the Middle East, Vol. 23, No. 1, 2 (2003), pp. 224-233.

Pita, Joseph A. "Interest Groups and the White House under Roosevelt and Truman," Political Science Quarterly, Vol. 102, No. 4 (Winter, 1987/1988), pp. 647-688.

Rosenberg, J. Phillip. "The Belief System of Harry S. Truman and its Effects on Foreign Policy Decision-Making during his Administration," Presidential Studies Quarterly, Vol. 12, No. 2 (Spring, 1982), pp. 226-238.

Rothwell, V. H. "Mesopotamia in British War Aims, 1914-1918," The Historical Journal, Vol. 13, No. 2 (June, 1970), pp. 273-294.

Rudd, Gordon W. "The Israeli Revisionist Historians and the Arab-Israeli Conflict Part One: From the Founding of Zionism to the 1967 War," The Journey of Military History, Vol. 67, No. 4 (October, 2003), pp. 1263-1270.

Scheffer, G. "Intentions and Results of British Policy in Palestine: Passfield's White Paper," Middle Eastern Studies, Vol. 9, No. 1 (January, 1973), pp. 43-60.

Schmidt, Sarah. "The Zionist Conversion of Louis D. Brandeis," Jewish Social Studies, Vol. 37, No. 1 (Winter, 1975), pp. 18-34.

Skard, Torild. "Getting Our History Right: How Were the Equal Rights of Women and Men Included in the Charter of the United Nations?," Norwegian Institute for International Affairs, No. 1 (June, 2008), pp. 37-60.

Stein, Kenneth. "A Historiographic Review of Literature on the Origins of the ArabIsraeli Conflict," American Historical Review, Vol. 96, No. 5 (December, 1991), pp. 1450-1465. 
Tannenbaum, Jan Karl. "France and the Arab Middle East, 1914-1920," Transactions of the American Philosophical Society, Vol. 68, No. 7 (1978), pp. 1-50

"Elizabeth P. MacCallum and the Arab-Israeli Conflict," The Journal of Israeli History, Vol. 19, No. 2 (Summer, 1998), pp. 93-107.

"The Jewish and Arab Lobbies in Canada and the UN Partition of Palestine," Israeli Affairs, Vol. 5, No. 4 (1999), pp. 229-244.

Toynbee, Arnold J. "The Ottoman Empire in World History," Proceedings of the American Philosophical Society, Vol. 99, No. 3 (June, 1955), p. 124.

Troen, Ilan. "Calculating the 'Economic Absorptive Capacity' of Palestine: A Study of the Political Uses of Scientific Research," Contemporary Jewry, Vol. 10, No. 2 (1989), pp. 19-38.

Troper, Harold. "Canada's Immigration Policy since 1945," International Journal, Vol. 48, No. 2, Migrants \& Refugees (Spring, 1993), pp. 255-289.

Twitchett, Kenneth J. "The Colonial Powers and the United Nations," Journal of Contemporary History, Vol. 4, No. 1, Colonialism and De-Colonialism (January, 1969), pp. 167-185.

Vidal, F.S. "Religious Brotherhoods in Moroccan Politics," Middle East Journal, Vol. 4 (October, 1950), pp. 427-446.

Wasserstein, Bernard. "Herbert Samuel and the Palestine Problem," The English Historical Review, Vol. 91, No. 361 (October, 1966.), pp. 753-775.

Waxman, Chaim Isaac. "Critical Sociology and the End of Ideology in Israel," Israeli Studies, Vol. 2, No. 1 (Spring, 1997), pp. 194-210.

Wicker, E. R. "Colonial Development and Welfare, 1929-1957: The Evolution of a Policy," Social and Economic Studies, Vol. 7, No. 4 (December, 1958), pp. 170-192.

Williams, J. E. "The Joint Declaration on the Colonies: An Issue of Anglo-American Relations, 1942-1944," British Journal of International Studies, Vol. 3, No. 3 (October, 1976), pp. 267-292.

Wilson, Evan M. "The Palestine Papers, 1945-1947," Journal of Palestine Studies, Vol. 2, No. 4 (Summer, 1973), pp. 33-54.

"The American Interest in the Palestine Question and the Establishment of Israel," Annals of the American Academy of Political and Social Science, Vol. 401, American and Middle East (May, 1972), pp. 64-73.

\section{(c) Thesis}

Anne Trowell Hillmer, "Canadian Policy on the Partition of Palestine, 1947," Carleton University, 1981. 